UNIVERSIDADE DE SÃO PAULO

FACULDADE DE FILOSOFIA, LETRAS E CIÊNCIAS HUMANAS

DEPARTAMENTO DE HISTÓRIA

PROGRAMA DE PÓS-GRADUAÇÃO EM HISTÓRIA SOCIAL

ELISANDRA MOREIRA DE LIRA

A criação do Parque Nacional da Serra do Divisor no Acre (1989) e sua inserção nas políticas federais de implantação de Unidades de Conservação federais no Brasil

(Versão Corrigida)

SÃO PAULO

2015 


\section{UNIVERSIDADE DE SÃO PAULO \\ FACULDADE DE FILOSOFIA, LETRAS E CIÊNCIAS HUMANAS \\ DEPARTAMENTO DE HISTÓRIA \\ PROGRAMA DE PÓS-GRADUAÇÃO EM HISTÓRIA SOCIAL}

A criação do Parque Nacional da Serra do Divisor no Acre (1989) e sua inserção nas políticas federais de implantação de Unidades de Conservação federais no Brasil

Tese apresentada ao Programa de PósGraduação em História Social, do Departamento de História da Faculdade de Filosofia, Letras e Ciências Humanas da Universidade de São Paulo, para obtenção do título de Doutora em História.

Orientadora: Prof. a Dra. Maria Amélia Mascarenhas Dantes

(Versão Corrigida)

São Paulo 


\section{A Deus, meu Criador e Salvador!}

"Confie no Senhor de todo o teu coração e não se apoie em seu próprio entendimento" (Pv. 3:5) 


\section{Agradecimentos}

Agradeço imensamente a professora Dra. Maria Amélia Mascarenhas Dantes, que esteve presente desde a minha entrada no Programa de Pós-Graduação em História Social, e não mediu esforços para a realização deste trabalho. Estou certa de que sem as suas orientações, não teria concluído esta tese. Obrigada querida Maria Amélia!

À Universidade Federal do Acre (UFAC), pelo incentivo ao aperfeiçoamento profissional. Ao Centro de Filosofia e Ciências Humanas (CFCH) e a Coordenação do Curso de Geografia, pela minha liberação das atividades docentes, no período em que estive em São Paulo.

À Coordenação de Aperfeiçoamento de Pessoal de Nível Superior (CAPES), pelo apoio financeiro, para cumprir essa jornada.

Também expresso meus sinceros agradecimentos aos professores: Adailton de Sousa Galvão (UFAC), Janes Jorge (UNIFESP), Frank Oliveira Arcos (UFAC), Jozimar Paes de Almeida (UEL), José Sávio da Costa Maia (UFAC), José Alves Costa (UFAC), e ao amigo Roger Domenech Colacios, pelas sugestões e indicações de leituras. Frank Arcos, obrigada também pela ajuda na confecção dos mapas!

Agradeço a geógrafa Francisca Pereira Mota, que me auxiliou durante as entrevistas e transcrições. A você Fran, meu muito obrigada!

Com imenso carinho, agradeço a todos meus familiares, pela torcida a meu favor: Antônio Batista de Lira e Francisca de Lima Moreira Lira, meus pais; Rosilda Moreira Lira e Elisângela Moreira de Lira Correia, minhas irmãs; Aíne Moreira de Souza e Ícaro Moreira Pereira, meus sobrinhos; Francisco Correia da Silva Júnior, meu cunhado; Raimundo Galvão Lobo e Alvira Maria de Sousa Lobo, tios do meu esposo, que me adotaram como filha no período em que estive em São Paulo.

Por fim, agradeço especialmente ao meu primeiro e grande amor, Paulo Lobo dos Santos, que suportou minha ausência e meu deu forças para concluir este trabalho. Espero no Senhor, que sejamos sempre felizes. 


\title{
A criação do Parque Nacional da Serra do Divisor no Acre (1989) e sua inserção nas políticas federais de implantação de Unidades de Conservação federais no Brasil
}

\begin{abstract}
Resumo
O objetivo desta tese é analisar a criação do Parque Nacional da Serra do Divisor (PNSD), no Acre, em 1989, como parte de um longo processo histórico de implantação de Unidades de Conservação no Brasil. Também procuramos avaliar como se deu a escolha da área onde se localiza o Parque e os procedimentos de elaboração e implantação do Plano de Manejo desta unidade. Antes de analisar o caso brasileiro, consideramos importante acompanhar como se deu a criação de áreas de conservação em outros países. Desde a criação do Parque Nacional de Yellowstone, em 1872, nos Estados Unidos, até a instalação da União Internacional pela Conservação da Natureza (UICN), em 1948, e sua atuação em defesa da criação de áreas protegidas nos vários continentes. A União também foi fundamental no estabelecimento de padrões internacionais para estas áreas. Pela pesquisa, pudemos observar que as primeiras Unidades de Conservação no Brasil, os Parques Nacionais dos anos 1930, seguiram o modelo norte-americano, que tinha como objetivo a preservação da natureza e a contemplação das belezas cênicas, não permitindo a presença de moradores. Já no ano 2000, quando foi criado o Sistema Nacional de Unidades de Conservação - SNUC, acompanhando os novos padrões internacionais, o país contava com diferentes categorias de Unidades de Conservação, agrupadas em dois grupos: as de uso integral, que não permitiam a presença de moradores, e as de uso sustentável, que tentavam conciliar a preservação da natureza com a presença de moradores. Para a realização do trabalho, além de amplo levantamento da bibliografia que trata das Unidades de Conservação no Brasil e em outros países, fizemos levantamento exaustivo da legislação federal referente a questões ambientais e áreas de preservação. Para o estudo do PNSD-AC, também levantamos legislação estadual e documentação relativa a organismos civis e aos movimentos sociais de cunho ambiental que ocorreram no Acre a partir dos anos 1970. Também realizamos entrevistas com especialistas que atuaram na elaboração do Plano de Manejo do PNSD. De acordo com os levantamentos realizados, uma das conclusões da pesquisa é que a escolha da região onde hoje está localizado o PNSD, não foi aleatória, tendo seguido a orientação de vários estudos que mostraram o potencial da região em termos de biodiversidade.
\end{abstract}

Palavras - Chave: Brasil; Políticas Ambientais; Unidades de Conservação; Parque Nacional da Serra do Divisor no Acre. 


\title{
The creation of the Serra do Divisor National Park in Acre (1989) and their involvement in federal policy Conservation Units deployment in Brazil
}

\begin{abstract}
The objective of this thesis is to analyze the creation of the Serra do Divisor National Park (PNSD) in Acre in 1989 as part of a long historical process Conservation Units deployment in Brazil. We also seek to assess how was the choice of the area where is located the Park and procedures for the establishment and implementation of the Management Plan of the unit. Before analyzing the Brazilian case, we consider important to monitor how the creation of protected areas in other countries was. Since the creation of Yellowstone National Park in 1872, the United States, until the installation of the International Union for Conservation of Nature (IUCN) in 1948, and his defense in action the creation of protected areas in the various continents. The Union was also instrumental in establishing international standards for these areas. For the study, we observed that the first protected areas in Brazil, the National Parks of the 1930s, followed the US model, which aimed to the preservation of nature and the contemplation of scenic beauty, not allowing the presence of residents. Already in 2000, when it was created the National Protected Areas System - SNUC, following the new international standards, the country had different categories of protected areas, grouped into two groups: the full use, which did not allow the presence residents, and sustainable use, which attempted to reconcile the preservation of nature with the presence of residents. To carry out the work, plus extensive survey of the literature dealing with protected areas in Brazil and other countries, did exhaustive survey of federal legislation concerning environmental issues and conservation areas. To study the PNSD-AC, also raised state legislation and documentation of civil organizations and social movements of an environmental nature that occurred in Acre from the 1970s also conducted interviews with experts who worked in the preparation of PNSD Management Plan. According to surveys conducted one of the research findings is that the choice of the region where today is located the PNSD, was not random, having followed the guidance of several studies that have shown the potential of the region in terms of biodiversity.
\end{abstract}

Key - Words: Brazil; Environmental policies; Protected Areas; Serra do Divisor National Park in Acre. 


\section{SUMÁRIO}

Introdução

\section{Capítulo 1}

Origem das Áreas Protegidas no Mundo e os Principais Eventos Internacionais que as Categorizaram: 1872 a 1992

1.1 O Parque Nacional Yellowstone: o primeiro modelo de área protegida -

1.2 Os principais eventos internacionais sobre áreas protegidas e a criação da União Internacional para a Conservação da Natureza e dos Recursos Naturais (UICN)

1.2.1 A Convenção para Preservação da Fauna e Flora em Estado Natural

1.2.2 A Convenção para Proteção da Flora, da Fauna e das Belezas Cênicas Naturais dos Países da América - "Convenção PanAmericana" (Washingyon, 1940)

1.2.3 A Criação da União Internacional para a Conservação da Natureza e dos Recursos Naturais - UICN (1948)

1.3 Algumas Considerações sobre o processo de criação, a nível mundial, de áreas protegidas

\section{Capítulo 2}

Gênese e Evolução das Unidades de Conservação no Brasil: 1930 a 2000

2.1 Políticas públicas ambientais e a criação das primeiras áreas protegidas no Brasil: 1930-1964

2.1.1 A Evolução das Políticas Públicas Ambientais ----------------------- 51

2.1.2 A Criação das Primeiras Unidades de Conservação: 1937-1961 ---- 58

2.2 Evoluções das políticas públicas ambientais e das unidades de conservação no período de 1964 a 1985

2.2.1 Desenvolvimentismo e políticas públicas ambientais ----------------
2.2. A proposta de criação do Plano do Sistema de Unidades de Conservação do Brasil (PSUC): 1975 - 1982

2.2.3 Unidades de Conservação criadas no período de 1968 a 1985 ---

2.3 Políticas públicas ambientais e evolução das unidades de conservação no período de 1985 a 2000

2.3.1 Evolução das Políticas Públicas Ambientais

2.3.2 Evolução e Consolidação do Sistema Nacional de Unidades de Conservação: 1989 a 2000

2.3.3 Evolução das Unidades de Conservação de 1986 a 2000

\section{Capítulo 3}

As Políticas de (Re)Ocupação para a Amazônia brasileira no Período Militar e a Criação das Primeiras Unidades de Conservação no Acre 
3.1 Localização Geográfica da Região Amazônica

3.2 As Políticas dos governos militares de (re)ocupação para Amazônia

3.2.1 Questionamentos sobre os resultados dos programas dos governos militares para a Amazônia

3.3 A (Re)Ocupação da Região Acreana nos anos 1970-1980 --------------- 109

3.3.1 Localização Geográfica do Estado do Acre ------------- 109

3.3.2 Nova onda de ocupação do território acreano pelos "Paulistas" --- 111

3.3.3 Conflitos pela Posse da Terra no Acre e Resistência aos Desmatamentos

3.4 A Implantação das Primeiras Unidades de Conservação Federais no Acre

3.4.1 A criação das primeiras unidades de conservação no Estado do Acre - 1980

3.5 Considerações Críticas sobre a Implantação de Unidades de Conservação no Acre

\section{Capítulo 4}

A Implantação do Parque Nacional da Serra do Divisor no Acre: 1976 a 1998

4.1 Localização Geográfica do Parque Nacional da Serra do Divisor PNSD

4.2 Os primeiros estudos para a implantação de unidades de conservação no sudoeste da Amazônia

4.2.1 O II PND e as questões ambientais

4.2.2 O relatório do IBDF: "Uma Análise de Prioridade para a Conservação da Natureza na Amazônia" de 1976

4.2.3 O Projeto RADAMBRASIL - 1977

4.2.4 O Plano do Sistema de Unidades de Conservação do Brasil PSUC, 1982 (II Etapa) -

4.2.5 A Elaboração dos Planos de Manejo dos Parques brasileiros: 19701980

4.3 A criação do Parque Nacional da Serra do Divisor - PNSD: 1989 -------

4.4 Elaboração e publicação do Plano de Manejo do PNSD-AC: 1995 a 1998

4.4.1 Atores envolvidos na coordenação e elaboração do Plano de Manejo do PNSD

4.4.2 Elaboração e Publicação do Plano de Manejo

4.5 Algumas Avaliações sobre o Processo de Criação do PNSD, Elaboração e Implantação do Plano de Manejo 


\section{Introdução}

A literatura tem nos mostrado que a história do homem, frente ao desafio da sobrevivência, continua interligada à utilização dos recursos naturais. Nosso grande desafio é conciliar o uso desses recursos, seja para a subsistência ou ainda para as atividades econômicas, sem causar sua extinção. Infelizmente, a diminuição dos recursos naturais continua crescendo e os problemas ambientais têm impactado de forma negativa a qualidade de vida das gerações atuais e certamente das futuras.

Uma das formas de preservação de parte da biodiversidade que ainda temos no Brasil, foi a criação de um Sistema Nacional de Unidade de Conservação (SNUC). As bases para criação de um sistema nacional de unidades de conservação iniciaram-se na década de 1930, com a publicação do Código Florestal (1934), que classificou as florestas em quatro categorias: protetoras, remanescentes, modelos, e de rendimento. $\mathrm{Na}$ categoria das florestas remanescentes, os parques nacionais foram considerados como áreas que mereciam ser preservadas, com restrições às atividades humanas. Depois do código florestal, diversos órgãos governamentais foram criados e vários regulamentos de proteção à natureza foram sendo aprovados. Com base nos modelos e categorização das áreas protegidas, publicadas em nível mundial pela União Internacional para a Conservação da Natureza e dos Recursos Naturais (UICN), o Instituto Brasileiro de Desenvolvimento Florestal (IBDF), publicou vários relatórios técnicos (1976, 1979, 1982 e 1989) que conduziram a solidificação de um sistema nacional de unidades de conservação no país. Depois dessas publicações, foi possível encaminhar ao Congresso Nacional, uma proposta de lei para estabelecer o sistema. E após muitas críticas e alterações, o sistema foi aprovado em 2000.

O SNUC definiu-se como um sistema constituído pelo conjunto das unidades de conservação (federais, estaduais e municipais). No regulamento deste sistema, o termo "conservação" foi definido como "o manejo do uso humano da natureza, compreendendo a preservação, a manutenção, a utilização sustentável, a restauração e a recuperação do ambiente natural, para que possa produzir o maior benefício, em bases sustentáveis, às atuais gerações, mantendo seu potencial de satisfazer as necessidades e aspirações das gerações futuras, além de garantir a sobrevivência dos seres vivos em geral". O regulamento também classifica as "unidades de conservação em dois grandes grupos: as de Proteção Integral - cuja finalidade baseia-se na manutenção dos 
ecossistemas livres de alterações causadas por interferência humana, admitindo apenas o uso indireto dos atributos naturais; e as de Uso Sustentável - que permitem a exploração do ambiente, de maneira a garantir a perenidade dos recursos ambientais renováveis e dos processos ecológicos, mantendo a biodiversidade, de forma socialmente justa e economicamente viável ${ }^{1}$.

O objetivo central do nosso trabalho foi analisar o processo de criação, em 1989, do Parque Nacional da Serra do Divisor (PNSD), uma unidade de conservação de proteção integral, localizada no Estado do Acre, como parte de um longo processo histórico de implantação dessas unidades no país. Procuramos avaliar como se efetivou a escolha da área onde se localiza o Parque e os procedimentos de elaboração e implantação do Plano de Manejo desta unidade, que compreendeu um período de vinte dois anos (1976 a 1998).

Afim de entendermos melhor o processo de implantação do PNSD, consideramos necessário fazer um estudo de como surgiram as primeiras áreas protegidas no mundo e o processo de implantação destas áreas no Brasil, acompanhando as políticas de proteção ambiental desde a década de 1930. Também realizamos um estudo mais detalhado da região amazônica, na busca de um entendimento sobre a relação entre o prejuízo ambiental causado pelas políticas de ocupação durante o regime militar e a implantação de unidades de conservação.

Para realizar este trabalho, fizemos um amplo levantamento da bibliografia que trata das unidades de conservação no Brasil e das primeiras áreas protegidas a nível mundial. Também foi realizado um levantamento exaustivo de toda a legislação federal referente às políticas ambientais e às unidades de conservação criadas até o ano 2000. As informações levantadas foram comparadas com os dados oficiais contidos no site do Instituto Chico Mendes de Conservação da Biodiversidade (ICMbio), órgão ligado ao Ministério do Meio Ambiente (MMA) e integrante do Sistema Nacional do Meio Ambiente (SISNAMA). Este Instituto é hoje responsável pela execução das ações do Sistema Nacional de Unidades de Conservação (SNUC), podendo propor, implantar, gerir, proteger, fiscalizar e monitorar as unidades de conservação instituídas pela União. Também comparamos os dados levantados com as informações fornecidas no site do

\footnotetext{
${ }^{1}$ BRASIL. Lei n. 9.985, de 16 de julho de 2000. Regulamenta o artigo 225, Parágrafo 1 incisos I, II, III e VII da Constituição Federal, institui o Sistema Nacional de Unidades de Conservação da Natureza e dá outras providências. Brasília: 2000.
} 
próprio MMA, onde existem dados atualizados tanto das políticas ambientais como das áreas protegidas existente no país.

Também foi necessário o levantamento dos planos de governos, programas, e projetos, dentro do período analisado, especialmente para o período militar, afim de compreendermos como se configuraram as políticas de ocupação e implantação de unidades de conservação na Amazônia.

Finalizando, para o estudo do PNSD-AC, fizemos um levantamento dos relatórios e projetos que selecionaram a região da Serra do Divisor. Para a análise do caso do Acre, além de levantamento da legislação estadual, buscamos informações sobre os movimentos sociais voltados para a proteção da floresta. Também realizamos entrevistas com especialistas que trabalharam na elaboração do Plano de Manejo do Parque. Entre os acervos visitados, destacamos: o Arquivo da Secretaria de Planejamento do Estado do Acre; o Acervo Digital do Patrimônio Histórico e Cultural Fundação Elias Mansour; o Arquivo do Governo do Estado do Acre - Casa Civil; a Biblioteca do IBAMA Acre; o acervo do ICMbio do Município de Cruzeiro do Sul-AC; e a Biblioteca da ONG SOS Amazônia. Nesta última, fizemos o levantamento de todo material relacionado à elaboração do plano de manejo do PNSD. Estes documentos também foram catalogados, para serem posteriormente disponibilizados no site da ONG.

A tese está dividida em quatro capítulos e procurou contemplar tanto a discussão temática como a linha cronológica do processo de criação de áreas protegidas: desde o surgimento do Parque Nacional de Yellowstone, em 1872, nos EUA; passando pelo processo de criação e legalização dessas áreas no Brasil (1930-2000); dando destaque às políticas de re-ocupação e de criação de áreas na região amazônica durante o regime militar; e, por fim, o processo de escolha e a criação do Parque Nacional da Serra do Divisor, no Acre, fechando com uma avaliação do processo de elaboração e implantação do Plano desta unidade.

No Primeiro Capítulo apresentamos um esboço do surgimento das primeiras áreas protegidas a nível mundial, começando com os Parques Nacionais dos Estados Unidos, que tinham como principal objetivo a preservação de refúgios da vida silvestre, e a contemplação da beleza cênica pela população urbana que crescia. Neste capítulo também analisamos a atuação de organismos internacionais, com destaque para União Internacional para a Conservação da Natureza e dos Recursos Naturais (UICN), que 
teve papel fundamental nos debates e no estabelecimento de novas categorias de áreas protegidas no mundo, com objetivos de manejo diferenciados.

No Segundo Capítulo fizemos um levantamento das políticas ambientais e da criação de unidades de conservação no Brasil, para o período de 1930 a 2000. Para viabilizar a análise, dividimos este período em três sub-períodos. O primeiro, iniciando em 1930 até 1964, quando ocorreu tanto a criação das primeiras unidades de conservação, como as primeiras políticas de proteção dos recursos naturais. O segundo sub-período, ficou concentrado entre 1964 a 1985, correspondendo ao contexto do regime militar. Nesta fase, teve seguimento o fluxo migratório para Brasília e regiões da porção Oeste do país. Esse sub-período foi caracterizado pelo autoritarismo político e pela importância dada às políticas de ocupação da região amazônica, que sofreu grande degradação de seus recursos. O último sub-período, teve início com a redemocratização do país, em 1985, passando pela aprovação da nova Constituição de 1988, indo até o ano de 2000, quando foi aprovada a Lei n. 9.985 de 18 de julho, que implantou o Sistema Nacional de Unidades de Conservação (SNUC).

As discussões sobre as políticas em âmbito federal, destinadas à ocupação da região amazônica pelos governos militares, no Capítulo Três, tiveram como foco mostrar como os incentivos físcais e creditícios para implantação de projetos agropecuários aceleraram a destruição das florestas e a concentração da propriedade de terras na região. Como consequência, ocorreram uma série de conflitos, principalmente no Estado do Acre, entre seringueiros e os "novos" donos da terra. Conflitos estes que tiveram grande repercussão no Brasil e em outros países, chamando a atenção para a questão da destruição da floresta amazônica.

Por fim, no Capítulo Quatro, tentamos compreender como a região da Serra do Divisor, localizada no Estado do Acre, porção mais ocidental do país, foi escolhida para a implantação de uma unidade de conservação federal, o Parque Nacional da Serra do Divisor, o que se efetivou em 1989. Também buscamos avaliar como foi a metodologia de elaboração do Plano de Manejo e sua eficácia atual. 


\section{CAPÍTULO 1}

\section{Origem das Áreas Protegidas no Mundo e os Principais Eventos Internacionais que as Categ1orizaram: 1872 a 1992}

"A história do homem mostra que, frente ao desafio da sobrevivência, os interesses práticos na utilização e proteção de recursos naturais existiram desde os primórdios do desenvolvimento das sociedades" ${ }^{2}$. No entanto, segundo Orci Teixeira, o grande desafio da humanidade é "conciliar o desenvolvimento com a proteção e a preservação ambiental, para não inviabilizar a qualidade de vida das futuras gerações e o exercício do direito de propriedade sobre os bens ambientais"3.

Durante séculos, a humanidade transformou os recursos da natureza em bens econômicos, a maioria das vezes à custa do equilíbrio dos ecossistemas, como mencionou Teixeira. Para o autor, as práticas econômicas predatórias fizeram com que o homem perdesse seu vínculo com a Terra, passando a tratá-la como propriedade privada, considerada simples fornecedora de insumos ou mesmo como depósito de resíduos $^{4}$. Trata-se de uma visão antropocêntrica, pela qual o homem considerou-se o centro e senhor do Universo.

Ao mesmo tempo, o reconhecimento dos recursos naturais e a intenção de proteger espaços territoriais se remetem à própria história da humanidade. Há evidências de que os povos, há milhares de anos, já tomavam medidas para proteger determinados sítios geográficos, especialmente ao tratar de animais sagrados, água pura, plantas medicinais e matéria-prima para uso futuro, mitos e ocorrências históricas, portanto reconheciam valores especiais que a natureza dispunha ${ }^{5}$. Povos da Índia, por

\footnotetext{
${ }^{2}$ CASTRO JR, Evaristo de; COUTINHO, Bruno Henriques; FREITAS, Leonardo Esteves de. Gestão da Biodiversidade e Áreas Protegidas. In: GUERRA, Antonio José Teixeira; COELHO, Maria Célia Nunes (Orgs.). Unidades de Conservação: Abordagens e Características Geográficas. Rio de Janeiro: Bertrand Brasil, 2009. p. 31.

${ }^{3}$ TEIXEIRA, Orci Paulino Bretanha. O Direito ao Meio Ambiente Ecologicamente equilibrado como Direito Fundamental. Porto Alegre: Livraria do Advogado, 2006. p. 21.

${ }^{4}$ Id., p.17.

${ }^{5}$ MILLER, K. R. Evolução do conceito de áreas de proteção - oportunidades para o século XXI. In: I Congresso Brasileiro de Unidades de Conservação, v.1, 1997, Curitiba. Anais... Curitiba: IAP: UNILIVRE/Rede Nacional Pró Unidades de Conservação, p. 3-21, 1997.p. 3.

Observação: na data de publicação do artigo o autor, Miller, era Vice-Presidente e Diretor do Programa de Recursos Biológicos do World Resources Institute, em Washington.
} 
exemplo, tinham a preocupação de proteger os peixes e outros animais, bem como as áreas florestadas 6 .

De acordo com Miller, na Indonésia, Filipinas e nas Ilhas do Pacífico, havia uma combinação de poderosos tabus sociais com rígidos controles administrados a nível de aldeia e, muitas vezes, com reforço religioso, tudo para evitar uma exploração que pudesse contrariar os interesses da comunidade ${ }^{7}$.

$\mathrm{Na}$ Ásia e Oriente próximo, observaram-se algumas restrições para a conservação da vida silvestre, desde as primeiras culturas pré-agrárias:

$\mathrm{Na}$ Índia, 400 anos antes de Cristo, todas as formas de uso e atividade extrativista foram proibidas nas florestas sagradas; 700 anos antes de Cristo, nobres assírios estabeleceram reservas de caça, similares às reservas de caça do Império Persa na Ásia Menor, estabelecidas entre 550 e 350 anos antes de Cristo; na China, foram estabelecidas leis de proteção para planícies úmidas durante o sexto século depois de Cristo; Veneza criou reservas de veados e javalis no início do século VIII; na Bretanha, foram promulgadas leis florestais no século $\mathrm{XI}^{8}$.

$\mathrm{Na}$ Inglaterra, a criação de áreas protegidas foi amadurecendo até que áreas de florestas foram cercadas para a formação de reservas de caça. Uma tendência que aflorou significativamente com o surgimento dos novos palácios rurais, no século XVI ${ }^{9}$. Com o avanço da fronteira agrícola, passou-se a aproveitar as denominadas "terras incultas", como as áreas de pastagem, charcos e montanhas, objetivando maior lucratividade sobre a terra e, já no século XVII, a necessidade de produção de madeira para a indústria naval contribuiu para uma administração mais equilibrada das matas ${ }^{10}$.

Ao citar o historiador Raymond Williams, Segawa mostrou que, da preservação de florestas para o plantio de árvores, foi um passo para a silvicultura transformar-se em uma forma de valorização das propriedades. Concomitante, o cultivo de árvores satisfazia aos interesses econômicos e atendia aos anseios estéticos da mitificação da vida do campo:

Para os defensores do melhoramento rural da Inglaterra, o paisagismo correspondia, na arte, à ideologia burguesa do melhoramento e à investigação

\footnotetext{
${ }^{6}$ MORAES, 2004 apud SILVA, Maria do Socorro Ferreira; SOUZA, Rosemeri Melo. Unidades de Conservação como estratégia de gestão territorial dos recursos naturais. Terra@Plural, Ponta Grossa, v. 3, n. 2, p. 241-259, jul./dez. 2009. p. 251.

${ }^{7}$ MILLER, 1997, p. 3.

${ }^{8}$ DAVENPORT; RAO, 2002 apud CASTRO JR, COUTINHO e FREITAS, op. cit., p. 31.

${ }^{9}$ SEgAWA, Hugo M. Ao Amor do Público: jardins no Brasil (1779-1911). 1994, 201f. Tese (Doutorado em Arquitetura e Urbanismo). Faculdade de Arquitetura e Urbanismo da Universidade de São Paulo, São Paulo, 1994. p. 20.

${ }^{10}$ Id., p. 20.
} 
da natureza e das modalidades de percepção. Agora que o homem produzia sua própria natureza, quer por meios físicos de melhoramento (terraplanagem com novas máquinas; drenagem e irrigação; bombeamento de água para locais elevados), quer pela compreensão das leis físicas da luz e das perspectivas e pontos de vista artificiais, fatalmente teria de modificar-se a decoração, de um simbolismo e iconografia limitados e convencionais, da terra imediatamente visível ${ }^{11}$.

Já nos Estados Unidos, no século XIX, os critérios de beleza, passaram a ser amplamente utilizados pelos defensores do meio ambiente. John Muir (1838-1914), por exemplo, considerado um dos grandes preservacionistas norte-americanos, foi defensor da proteção do Vale Yosemite da Califórnia e fundador do Clube Sierra (que hoje sobrevive como importante grupo de defesa ambiental). Em seus textos, ele defendeu a conservação da natureza: "todos precisam de beleza assim como de pão [...] de lugares onde se divertir e orar, onde a Natureza possa curar, alegrar e fortalecer tanto o corpo quanto a alma" $"$.

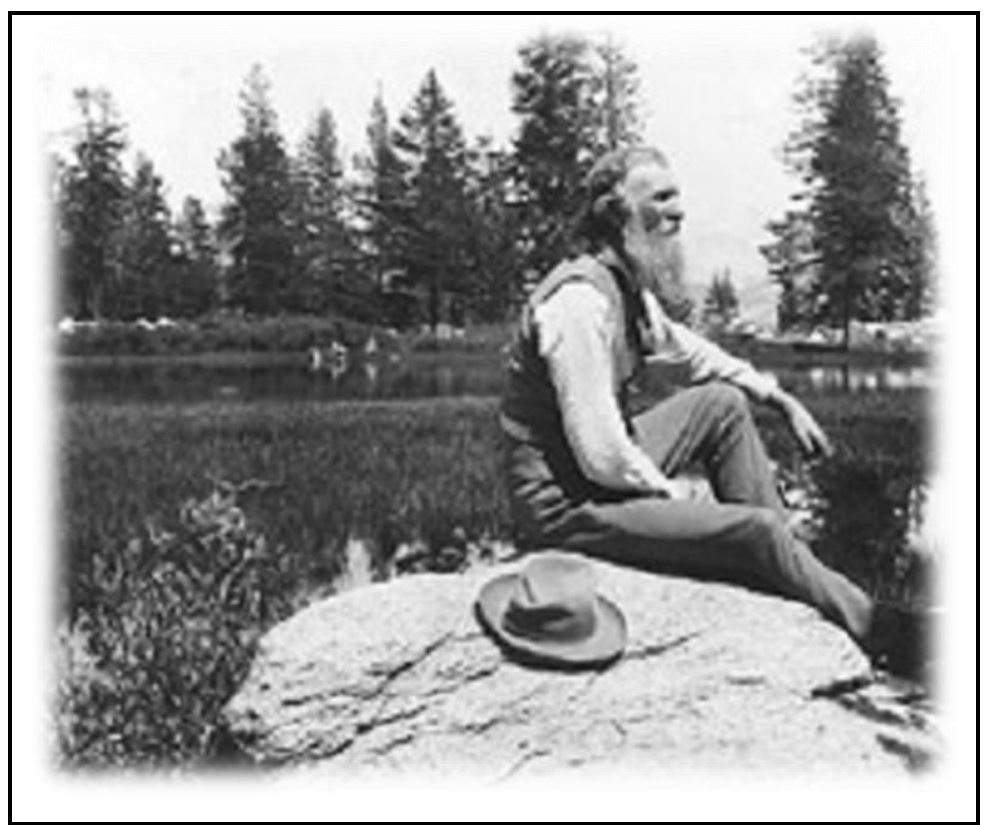

Figura 1 John Muir contemplando a natureza Fonte: eJournal USA, 2008, p. 11.

Foi justamente nos Estados Unidos, no final século XIX, que surgiu a primeira iniciativa concreta de preservação da natureza no mundo, com a criação do Parque Nacional de Yellowstone. Uma área ainda não comprometida pela ação antrópica, que passou a ser totalmente reservada à preservação de seus recursos naturais, com o

\footnotetext{
${ }^{11}$ WILLIAMS apud SEGAWA, op.cit., p. 20.

${ }^{12}$ A Própria História dos Estados Unidos. eJOURNAL USA. Washington, DC 20547: Departamento de Estado dos EUA, v. 13. n. 7, julho de 2008, p. 11. Disponível em <http://www.america.gov/publications/ejournals.html>. Acesso em: 05 jul. 2014.
} 
objetivo de salvaguardar recantos dotados de beleza cênica para apreciação da população urbana que crescia. É o que trataremos a seguir.

\subsection{O Parque Nacional Yellowstone: o primeiro modelo de área protegida}

A literatura permite apontar que a criação do Parque Nacional de Yellowstone, em 1872, pode ser considerada um marco divisor do processo que celebra a preservação dos recursos naturais. O parque foi criado em uma época de maciça expansão da fronteira agropecuária e mineral para o oeste dos EUA. Para Drummond et. al., a socialização do usufruto das belezas cênicas para toda a população e a proibição de qualquer forma de exploração econômica dos seus recursos naturais formaram as principais premissas da nascente era dos Parques Nacionais, modelo instaurado pelo Yellowstone $^{13}$.

No ano de 1864, o Congresso Norte-americano cedeu uma área à Califórnia para a criação de uma Reserva Pública. Esta área localizava-se no Vale do Yeosemite e no Bosque do Mariposa Grove of Giante Sequoias. Depois da criação do Parque de Yellowstone, o naturalista John Muir, que já defendia a preservação do patrimônio natural americano, sugeriu que também fosse criado um parque na Reserva doada pelo governo da Califórnia. E em 1890, foi instituída naquela área o Parque Nacional de Yosemite $^{14}$.

Ao tratar do Yellowstone, Luis Bolin, relata que não é fácil falar, em breves palavras, das maravilhas do parque. Situado parte em Montana e parte em Wyoming, com $9.000 \mathrm{~km}^{2}$ de superfície, $500 \mathrm{~km}$ de atalhos e 3.000 repuxos de águas termais. Sua criação foi consequência de um relatório subscrito por membros da Expedição Washburn que, ao pesquisa-lo, comprovaram a existência de um território com beleza única, digno de ser conservado a qualquer custo ${ }^{15}$.

Entre suas atrações destacam-se, nas palavras de Bolin, "três rios frutiferos de águas alegres e paisagem variadas, nos encantadores vales: do Madison, de Gibbons e

\footnotetext{
${ }^{13}$ DRUMMOND, José Augusto; DIAS, Teresa Cristina Albuquerque de Castro; e BRITO, Daguinete Maria Chaves. Atlas das Unidades de Conservação do Estado do Amapá. Macapá: MMA/IBAMA-AP; GEA/SEMA, 2008, p. 13.

${ }^{14}$ ALMEIDA, Fabiana Pueza de. Histórico de Criação das Categorias de Unidades de Conservação no Brasil. 247f. Dissertação (Mestrado em Conservação da Biodiversidade e Desenvolvimento Sustentável). Nazaré Paulista-SP: Escola Superior de Conservação Ambiental e Sustentabilidade / Instituto de Pesquisas Ecológicas - IPÊ, 2014, p. 28.

${ }^{15}$ BOLIN, Luis A. Prodígios da Natureza: os grandes parques nacionais dos Estados Unidos. (Tradução de Euzínia Rêgo Santos) Rio de Janeiro: Lidador, 1965, p. 90.
} 
Firehole". Além das Cataratas Baixas do rio Yellowstone, tem-se o gêiser de maior fama em seus limites, que a intervalos de aproximadamente uma hora e com uma pontualidade que justifica seu nome, Old Faithful (Velho Fiel), descarrega 50.000 litros de água que, no inverno caem ao solo já congeladas, não obstante brotar, quase fervendo, a uma temperatura de $96^{\circ} \mathrm{C}$. "A coluna formada pela água alcança 40 metros de altura e proporciona aos visitantes um espetáculo de grande beleza, não isento de emoção" $"$.

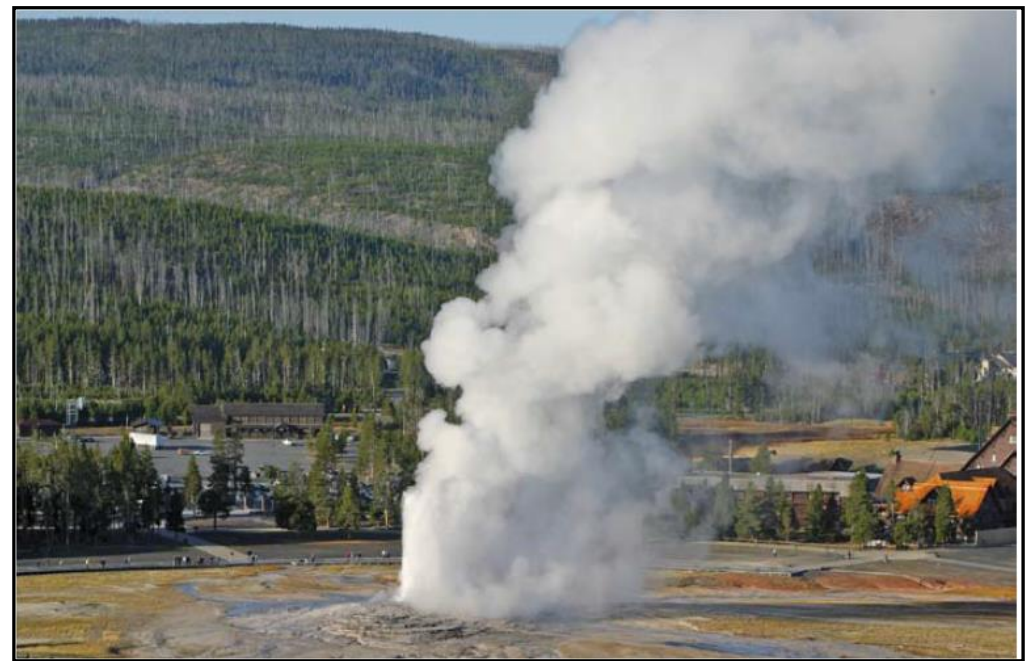

Figura 2 Gêiser no Parque Nacional de Yellowstone ${ }^{17}$ Fonte: DUDLEY, 2008, p. $61^{18}$.

Segundo Drummond, com a criação legal deste primeiro Parque Nacional, nos EUA, deu-se início a uma busca mais organizada por normas de proteção da natureza ${ }^{19}$. Soares concorda com a afirmativa de Drummond, ao comentar, em um de seus trabalhos sobre as primeiras regras jurídicas de preservação de ambientes naturais:

[...] as primeiras regras jurídicas de preservação de hábitat natural, portanto, uma legislação nacional relativa ao meio ambiente na moderna concepção, ...(foram)... as normas norte-americanas do final do século XIX sobre a instituição de grandes parques nacionais: em 1872, a criação do parque nacional de Yellowstone, seguida dos parques de Yosemite, General Grant, Sequoia e MountRainier, este último em 1899[... $]^{20}$.

\footnotetext{
${ }^{16}$ BOLIN, 1965, p. 90.

${ }^{17} \mathrm{O}$ Parque de Yellowstone possui uma paisagem que continuamente é modificada por forças geológicas. Um lugar que contem numerosos gêiseres e fontes termais.

${ }^{18}$ DUDLEY, Nigel (editor). Guidelines for Applying Protected Area Management Categories. Gland, Switzerland: UICN, 2008.

${ }^{19}$ DRUMMOND, Jose Augusto. Devastação e Preservação Ambiental: os parques nacionais do Estado do Rio de Janeiro. Niterói: EDUFF, 1997. p. 143.

${ }^{20}$ SOARES, Guido Fernando Silva. A Proteção internacional do meio ambiente. Barueri-SP: Manole, 2003, p. 17.
} 
O conceito de Parque Nacional ficou definido como área natural selvagem, ou seja, parte do território nacional que ainda não tivesse sido modificado pelas atividades humanas. Para Vallejo, a criação dos parques foi fruto da expansão urbano-industrial, que levou ao quase total extermínio das comunidades indígenas, e à expansão das fronteiras para a região oeste do país. Além disso, existia a preocupação de reservar grandes áreas para fins de lazer, de uma população urbana que crescia rapidamente, e ainda o receio dessa área ser ocupada ou vendida ${ }^{21}$.

A implantação do primeiro Parque Nacional na América (Yellowstone), ocorreu junto à consolidação do capitalismo americano e a urbanização acelerada. Neste sentido, os parques significavam a reserva de grandes áreas naturais que ficariam à disposição das populações urbanas para fins de recreação ${ }^{22}$, com foco voltado para a proteção da vida selvagem (wilderness) ${ }^{23}$. A ideologia preservacionista conduziu à criação desses espaços protegidos, cujo objetivo era manter remanescentes da natureza intocados, para contemplação do público e para servir de testemunho para gerações futuras, ficando clara a distância na relação homem e natureza, ou melhor, homem e "refúgios" de vida silvestre ${ }^{24}$.

Entretanto, a visão preservacionista, não impediu que a degradação ambiental continuasse naquele país, "nos seus grandes centros industriais, de maneira acelerada, a partir dos efeitos cumulativos da Revolução Industrial e da consagração de uma filosofia de produção, posteriormente denominada "fordismo" 25.

Mas, temos que reconhecer que a partir da criação do Parque Nacional de Yellowstone, houve avanços em termos de conservação da natureza, pois nestes espaços não era permitida a interferência ou exploração de recursos madeireiros, depósitos minerais ou outras formas de exploração dentro da área. Assim, segundo Milano,

\footnotetext{
${ }^{21}$ Quanto ao extermínio de comunidades indígenas que já viviam no local, Vallejo afirma que os preservacionistas norte-americanos esqueceram-se destas populações que, segundo ele, tinham vivido em harmonia com a natureza por milhares de anos. (VALLEJO, Luiz Renato. Unidades de Conservação: uma discussão teórica à luz dos conceitos de território e de políticas públicas. Geographia, v. 4, n. ${ }^{\circ}$ 8, p. 57 78,2002 , p. 59).

${ }^{22}$ No século XIX, as premissas capitalistas centradas nos significados da produção (terra, trabalho e capital) foram se consolidando, e a economia clássica, ao tratar os recursos da Terra como mercadoria, considerava irrelevante a degradação ambiental (VALLEJO, Luiz Renato. Os Parques e Reservas como Instrumentos do Ordenamento Territorial. In: ALMEIDA, Flávio Gomes; SOARES, Luiz Antônio (Orgs.). Ordenamento Territorial: coletânea de textos com diferentes abordagens no contexto brasileiro. Rio de Janeiro: Bertrand Brasil, 2009. p.157-194, p. 159).

${ }^{23}$ DIEGUES, Antônio Carlos. O Mito Moderno da Natureza Intocada. 6. ${ }^{a}$ ed. São Paulo: Edusp/NUPAUB, 2008; VIANNA, Lucila Pinsard. De Invisíveis a Protagonistas: populações tradicionais e unidades de conservação. São Paulo: Annablume/Fapesp, 2008; SILVA, \& SOUZA, 2009; VALLEJO, 2009.

${ }^{24}$ CASTRO JR; COUTINHO e FREITAS, op. cit., p. 32.

${ }^{25}$ SOARES, 2003, p.18.
} 
"motivados por tão interessante e distinta iniciativa, outros países aderiram ao procedimento e iniciaram a criação de Parques e outras áreas protegidas "26.

O Parque de Yellowstone foi o primeiro exemplo da preservação de grandes áreas naturais no interesse público. Em seguida, outros países criam parques nacionais:

[...] o Canadá criou seu primeiro parque nacional em 1885, a Nova Zelândia em 1894, a África do Sul e Austrália em 1898. A América Latina foi um dos primeiros continentes a copiar o modelo de parque nacional sem população humana residente. O México estabeleceu sua primeira reserva florestal em 1894, a Argentina em 1903, o Chile em 1926 e o Brasil em 1937 com objetivos similares ao de Yellwstone, isto é, proteger áreas naturais de grande beleza cênica para usufruto dos visitantes (de fora da área).

Já na Europa, os parques nacionais, como os Alpes, criados em 1914, foram criados para manter áreas naturais onde se pudessem realizar pesquisas de flora e fauna ${ }^{27}$.

Também de acordo com Milano, até 1898, quando foi criado o Krüger National Park, na África do Sul, o principal objetivo da proteção das áreas protegidas pautava-se em garantir que os recursos naturais contidos nestes ambientes, em essência paisagens de grande expressão, permanecessem em estado original para usufruto da população. No caso do Krüger, "as razões fundamentavam na necessidade de se criarem condições para recuperação de populações animais que vinham sendo indiscriminadamente massacradas, em decorrência do desenvolvimento e melhoria dos armamentos ${ }^{28}$.

O modelo de Parques foi se espalhando pelo mundo numa perspectiva dicotômica entre "povos" e "parques". Na visão de Silva e Souza, este modelo partiu do princípio de que a presença humana sempre seria devastadora para a natureza, e assim deixou-se de considerar os diferentes estilos de vida das "populações tradicionais" existentes em outros países como o caso da América do Sul e da África ${ }^{29}$.

A dicotomia criada em torno da relação entre natureza e ser humano, segundo Gómes-Pompa e Kaus, confirma o apego do pensamento preservacionista inicial, de criação de ambientes selvagens, intocados. Os autores citam que:

As crenças clássicas de conservação geralmente afirmam que existe uma relação inversa entre as ações humanas e o bem-estar do meio ambiente natural. $\mathrm{O}$ meio ambiente natural e o mundo urbano são vistos como uma dicotomia e a preocupação costuma ser focada nas ações humanas que afetam

\footnotetext{
${ }^{26}$ MILANO, Miguel Serediuk. Unidades de Conservação - Técnica Lei e Étia para a Conservação da Biodiversidade. In: BENJAMIM, Antônio Herman (coord.) Direito Ambiental das Áreas Protegidas: o regime jurídico das unidades de conservação. p. 3-41. Rio de Janeiro: Forense Universitária, 2001, p. 6.

${ }^{27}$ DIEGUES, 2008, p. 101.

${ }^{28}$ MILANO, op. cit., p. 7.

${ }^{29}$ SILVA \& SOUZA, 2009, p. 252.
} 
negativamente a qualidade de vida, de acordo com padrões urbanos. Montanhas, desertos, florestas e vida selvagem formam um conjunto que é considerado "natureza", área desenvolvida e mantida na ausência de seres humanos ${ }^{30}$.

Diegues também considera esta questão quando, em seu livro " $O$ Mito Moderno da Natureza Intocada”, afirma que a maioria das áreas protegidas criadas no mundo ocidental baseou-se no mito da natureza intocada. Neste sentido, o conflito entre as estratégias de conservação da natureza e as populações humanas residentes nessas áreas, que também eram responsáveis pela manutenção da diversidade biológica, surgiu concomitante à criação das áreas protegidas ${ }^{31}$.

Para Diegues esta forma de preocupação com o ambiente natural tinha como objetivo a proteção da vida selvagem ameaçada pelo avanço da civilização urbanoindustrial que, segundo os criadores dos parques, era uma civilização destruidora da natureza. Para o autor, esse modelo deixava claro que a única forma de proteger a natureza era afastá-la do ser humano ${ }^{32}$.

Vemos assim que, no século XIX o modelo norte-americano de área protegida, representada pelos Parques Nacionais foi sendo incorporado por outros países, na perspectiva de preservação da natureza.

Somente a partir de meados do século XX, a realização de grandes eventos internacionais em defesa da natureza (como a Convenção para Preservação da Fauna e Flora em seu Estado Natural e a Convenção para Proteção da Flora, da Fauna e das Belezas Cênicas dos Países da América), e o surgimento de organismos que lutavam em defesa da natureza (especialmente a União Internacional para a Conservação da Natureza e dos Recursos Naturais - UICN e, no seu âmbito, a Comissão de Parques Nacionais e Áreas Protegidas - CPNAP) contribuiu para o fortalecimento das discussões em torno da proteção da natureza.

Tais fatos levaram a mudanças no conceito de parques e na criação de novos tipos de áreas protegidas, com características específicas de manejo e manutenção. É o que trataremos a seguir.

\footnotetext{
${ }^{30}$ GÓMES-POMPA e KAUS. Domesticando o Mito da Natureza Selvagem. Bioscience, 42(4), p. 125 147, 1992 (Trad. De Dany Patarra), p. 127.

${ }^{31}$ BENSUSAN, Nurit. Conservação da Biodiversidade em áreas protegidas. Rio de Janeiro: Editora FGV, 2006; LEUZINGER, Márcia Dieguez. Natureza e Cultura: unidades de conservação de proteção integral e populações tradicionais residentes. Curitiba: Letra da Lei, 2009.

${ }^{32}$ Os argumentos que apoiam a existência de um mundo natural selvagem, intocado e intocável são considerados por Diegues, míticos e simbólicos, denominados por ele de neomitos (DIEGUES, 2008).
} 


\subsection{Os principais eventos internacionais sobre áreas protegidas e a criação da União Internacional para a Conservação da Natureza e dos Recursos Naturais (UICN)}

Segundo a literatura, durante o período entre-guerras, começou a ganhar corpo a percepção de que os Estados Nacionais estavam cada vez mais interdependentes e que a cooperação era algo importante nas relações internacionais. Teve início então a prática da diplomacia multilateral, com o surgimento de organismos como a Liga das Nações e a Organização Internacional do Trabalho - OIT, sediadas em Genebra (Suíça). Podem ser lembrados, também, a União Pan-Americana, no continente americano (1910), antecessora da atual Organização dos Estados Americanos (1948) e, a atuação de uma entidade que lhe é subordinada, a Organização Pan-Americana de Saúde - OPAS (1902), ambas com sede em Washington ${ }^{33}$.

A liga das Nações e a Organização Internacional do Trabalho ${ }^{34}$ surgiram após a primeira conflagração mundial, embasada em um projeto anglo-americano influenciado por ideias do Presidente norte-americano Woodrow Wilson. Foram instaladas em janeiro de 1919, pelo Tratado de Versalhes, o mesmo que estabeleceu os termos de paz na Europa, pondo fim oficialmente à primeira Guerra Mundial. A intenção da Liga estava centrada na preservação da paz internacional que, segundo este organismo, deveria ser principalmente de caráter moral, a fim de evitar futuros $\operatorname{conflitos}^{35}$. Já a OIT, seria responsável pela formulação e aplicação de normas internacionais do trabalho ${ }^{36}$.

Em 1943, dando prosseguimento à ideia de manter a articulação dos países para garantir a paz e a segurança mundiais, a China, os Estados Unidos, o Reino Unido e a União Soviética assinaram em Moscou, URSS, outro compromisso que reforçava a intenção de assegurar a paz. Em 1945, durante a Conferência de Yalta, realizada na Criméia (antiga URSS), Roosevelt, Churchill e Joseph Stalin, então secretário geral do Partido Comunista da URSS, anunciaram a criação de uma nova organização que defendesse a paz mundial. Assim, entre os dias 25 de abril e 25 de junho, cinquenta

\footnotetext{
${ }^{33}$ SOARES, 2003, p. 18.

${ }^{34}$ Agência do Sistema das Nações Unidas com uma estrutura tripartite, composta de representantes de governos e de organizações de empregadores e de trabalhadores.

35 VIANNA, Regina Cerece. A Liga das Nações e a ONU - Na busca da paz, do Direito, da Justiça e da vida. Revista Âmbito Jurídico, n. 83, ano XIII, dez. de 2010 (não paginado).

36 ORGANIZAÇÃO INTERNACIONAL DO TRABALHO. História. Brasília: Escritório no Brasil. Disponível em: < http://www.oitbrasil.org.br/content/hist\%C3\%B3ria>. Acesso em 13 de dezembro de 2014 (não paginado).
} 
países reuniram-se na Conferência de São Francisco, em São Francisco, Estados Unidos, e implantaram a Organização das Nações Unidas - $\mathrm{ONU}^{37}$, que substituiu a Liga das Nações ${ }^{38}$.

Os objetivos dessa Organização baseavam-se na manutenção da paz internacional; na defesa dos direitos humanos; no estabelecimento de relações amistosas entre as nações e na cooperação dos países na solução de problemas internacionais de ordem econômica, social, cultural e humanitária, dentre outros ${ }^{39}$.

Para Ribeiro, em primeiro lugar, a ONU precisava desenvolver ações que visassem minimizar os fatores capazes de desencadear conflitos entre países, como a falta de alimentos ou o acesso a recursos naturais. Foi assim, instituída, em 1945, a Food and Agriculture Organization - FAO, com sede em Roma, Itália. Para Ribeiro, o embrião das discussões ambientais da ONU surgiu na FAO, apesar de ter seu foco de ação na produção de alimentos (pois previa-se uma crise mundial de alimentos para 1947, devido à destruição de áreas agrícolas durante os anos de guerra) e, depois, na regulação de sua distribuição no mundo, a Organização também tratou da conservação dos recursos naturais ${ }^{40}$.

Ressaltamos ainda a criação da United Nations Educational, Scientific and Cutural Organization - UNESCO, que também passou a discutir e a propor ações relacionadas ao ambiente natural. Ela foi fundada em 1946, com sede em Paris, França e

${ }^{37}$ RIBEIRO, Wagner Costa. A Ordem Ambiental Internacional. $2^{\mathrm{a}}$ ed. São Paulo: Contexto, 2010, p. 59 .

${ }^{38} \mathrm{~A}$ antecessora imediata das Nações Unidas foi a Liga das Nações, constituída em 28 de abril de 1919 na Conferência de Versalhes. Seu objetivo era solucionar as disputas internacionais mediante o arbítrio de um organismo coletivo e não pelo equilíbrio militar entre as potências, como ocorrera na Europa desde a paz de Vestfália, em 1648, até a primeira guerra mundial. Essa organização teve pouca eficácia no cumprimento de sua missão devido à ausência dos Estados Unidos, da União Soviética (até 1934) e de outras potências, e ao apogeu da exaltação nacionalista em estados como Itália, Alemanha e Japão, cujos atos de expansionismo provocaram a deflagração da segunda guerra mundial. A Liga das Nações dissolveu-se formalmente em 18 de abril de 1946, quando cedeu seus organismos à ONU (ONU. Organização das Nações Unidas. Formação da ONU. Disponível em; < http://www.batalhaosuez.com.br/onu-OrganizacaoDasNacoesUnidas.htm> Acesso em 12 nov. 2014.)

${ }^{39}$ ALBUQUERQUE, Armando. Organização das Nações Unidas - ONU: como surgiu a ONU? p. 1-4. Disponível em: <http://armandoalbuquerque.com/organizacoes_das_nacoes_unidas.pdf >. Acesso em: 05 dez. 2014.

Dentre as várias organizações criadas neste período, podemos apontar o Fundo Monetário Internacional FMI (criado em 1944, tinha como objetivo fundamental reduzir o desequilíbrio das balanças de pagamentos dos países membros mediante a concessão de créditos procedentes de seus próprios recursos e a estabilização do câmbio); o Banco Mundial (criado em 1944, na conferência de Bretton Woods, da mesma forma que o FMI); o Acordo Geral de Tarifas e Comércio - GATT (criado em Genebra, em 1947, seus objetivos fundamentais eram o fomento dos acordos de redução tarifária, a supressão de barreiras aos intercâmbios comerciais e a eliminação de discriminações nesse campo).

${ }^{40}$ RIBEIRO, 2010, p. 61. 
se tornou o principal organismo da ONU a abordar a questão ambiental, tendo como meta promover o intercâmbio científico e tecnológico entre os países ${ }^{41}$.

Como o sistema das Nações Unidas não tinha nenhuma agência de cunho ambiental, a UNESCO, entrou em cena e agiu como patrocinadora de uma nova instituição. Com ajuda de dezoito governos, sete organizações internacionais, fundou a União Internacional para a Conservação da Natureza e dos Recursos Naturais - UICN ${ }^{42}$, uma das mais antigas organizações conservacionistas do mundo, criada em 1948, em Fontainebleau, França ${ }^{43}$.

Nesse contexto de discussões ambientais, as áreas protegidas entraram em cena em vários encontros mundiais. Vallejo, ao escrever sobre os "Parques e Reservas como Instrumento do Ordenamento Territorial" destacou como eventos de grande importância sobre este tema: a Convenção para a Preservação da Fauna e da Flora em Estado Natural (Londres, 1933); a Convenção Pan-americana de Proteção da Natureza e Preservação da Vida Selvagem do Hemisfério Ocidental (Washington, 1940); o Congresso organizado pelo governo francês e pela Organização das Nações Unidas para a Educação, Ciência e Cultura (Unesco, 1948); a fundação da União Internacional para a Proteção da Natureza (1948), posteriormente denominada União Internacional para a Conservação da Natureza (UICN), englobando agências governamentais e não governamentais, que passou a coordenar e iniciar trabalhos de cooperação internacional no campo da conservação da natureza; e os Congressos Internacionais de Parques Nacionais, realizados a cada dez anos, desde $1962^{44}$.

Segundo Drummond, as áreas protegidas estavam crescendo por todo o mundo e o critério para a escolha dessas áreas persistia na beleza cênica local, embora relativizado. Mas, também, o critério de acessibilidade foi ganhando importância na seleção das áreas, devido ao rápido crescimento do público interessado em visitá-las e usufruir do contato natural ${ }^{45}$. Também,

[...] O desenvolvimento da ciência da ecologia criou uma preocupação em proteger parcelas de ecossistemas que, por variados motivos, fossem considerados escassos, ou ameaçados, ou de grande valor para a pesquisa científica, mesmo que

\footnotetext{
${ }^{41} \mathrm{Id}$.

${ }^{42}$ CHRISTOFFERSEN, Leif E. IUCN: A Bridge-Builder for Nature Conservation. p. 59-69. GREEN GLOBE YEARBOOK, 1997.p. 60.

${ }^{43}$ RIBEIRO, 2010, p. 62.

${ }^{44}$ VALLEJO, 2009, p. 160.

${ }^{45}$ DRUMMOND et. al., 2008, p. 14.
} 
não tivessem atrativos estéticos ou não fossem particularmente atraentes para visitantes $[\ldots]^{46}$.

Diante do desenvolvimento da Ecologia, surgiram assim outros critérios científicos para a seleção das áreas protegidas. Com a diversificação de objetivos e critérios de seleção das áreas naturais protegidas em diferentes países, e o consequente aumento da complexidade do tema, era necessário definir conceitos em nível internacional ${ }^{47}$. Levando-se em conta tais considerações, foi assinada em 1933, em Londres, a Convenção para a Preservação da Fauna e Flora em Estado Natural, que definiu um conceito padrão para Parques Nacionais. Depois dessa Convenção outras foram realizadas sempre buscando a defesa do ambiente natural.

\subsubsection{A Convenção para Preservação da Fauna e Flora em Estado Natural} (Londres, 1933)

Como mencionamos, o primeiro evento internacional de relevância para a proteção da natureza aconteceu em 1933, em Londres, a Convenção para Preservação da Fauna e Flora em Estado Natural. A Inglaterra convocou os países que mantinham colônias na África, e neste evento, foi elaborado um documento que almejava preservar não apenas os animais individualmente, mas a fauna e a flora em seu conjunto. Segundo Ribeiro, "A Convenção foi assinada pelas potências europeias que mantinham territórios na África e procurou estabelecer mecanismos de preservação de ambientes naturais na forma de parques, conforme o modelo adotado nos Estados Unidos" ${ }^{48}$.

McCormick acrescenta ainda que esta Convenção se manifestou principalmente em resposta ao grande extermínio de animais selvagens na África, pois estes animais eram vistos como pestes agrícolas, ou portadores de epidemias para a criação doméstica. Segundo dados da época, foram mortos 321.518 animais em operações anti tsé-tsé entre 1924 e 1945, somente na Rodésia meridional ${ }^{49}$.

Entretanto, na visão de McCormick esta conferência ganhou certa antipatia das populações locais, pois o conceito de parques baseava-se na preservação da vida

\footnotetext{
46 Id., p. 14.

${ }^{47}$ Ibid., p. 14.

${ }^{48}$ RIBEIRO, 2010, p.54.

49 McCORMICK, John. Rumo ao Paraíso: a história do movimento ambientalista. Rio de Janeiro: Editora Relume-Dumará, 1992, p. 37.
} 
selvagem. Assim, os animais estavam sendo protegidos sem levar em consideração os direitos tradicionais de caça ${ }^{50}$.

Não podemos deixar de destacar que foram apresentadas quatro categorias de áreas protegidas, nesta Convenção: Parque Nacional, Reservas de Regiões Virgens, Reserva da Fauna e da Flora, e Reserva com proibição para caça e coleta ${ }^{51}$. Além do conceito de Parque Nacional que ganhou ênfase a partir de algumas características sugeridas para este modelo de área protegida. Os parques foram definidos como áreas controladas pelo poder público, cujos limites não deviam ser alterados; recintos de propagação, proteção e preservação da fauna silvestre e da vegetação nativa; e para a preservação de objetos de interesse estético, geológico, pré-histórico, arqueológico; ou outros interesses científicos; para o benefício e desfrute pelo público em geral; também, áreas com proibição da caça, abate ou captura da fauna, e destruição ou coleta da flora ${ }^{52}$.

Para Quintão, o conceito de parques nacionais ganhou, então, características mais especificas. Considerado de grande importância para a época, já que o movimento para a criação dos mesmos, havia se espalhado por diversos países do mundo, e o nome Parque Nacional estava sendo usado para designar áreas com diferentes objetivos de manejo ${ }^{53}$.

\subsubsection{A Convenção para Proteção da Flora, da Fauna e das Belezas Cênicas Naturais dos Países da América - “Convenção Pan-Americana" (Washington, 1940)}

Sete anos depois da Convenção para Preservação da Fauna e Flora em Estado Natural, outro evento considerado de destaque aconteceu em Washington (1940), sob a égide da União Pan-Americana, a Convenção para Proteção da Flora, da Fauna e das Belezas Cênicas Naturais dos Países da América, também conhecida como “Convenção Pan-Americana”. Nesta, foram discutidos: as experiências de cada nação ali representada; os resultados da Convenção de Londres; o comprometimento dos

\footnotetext{
${ }^{50}$ Id., p.37.

${ }^{51}$ ALMEIDA, 2014, p. 23.

${ }^{52}$ BRITO, Maria Cecília Wey de. Unidades de Conservação: intenções e resultados. $2^{\text {a }}$ ed. São Paulo: Annablume: Fapesp, 2003. p. 23; QUINTÃO, Angela Tresinari B. Evolução do Conceito de Parques Nacionais e sua relação com o processo de desenvolvimento. Brasil Florestal, n. 54, Ano XII, p. 13-27, abr/mai/jun., 1983, p. 15.

${ }^{53}$ QUINTÃO, op. cit., p. 15. (Quando da publicação de seu artigo AngelaTresinari B. Quintão trabalhava como Arquiteta do Departamento de Parques Nacionais e Reservas Equivalente, $M$. Sc. "LandscapeEcology, Design andMaintenance" pela Universidade de Londres).
} 
países sul-americanos a criar áreas protegidas em seus territórios; e os parâmetros para os acordos internacionais que envolvessem conservação da natureza ${ }^{54}$. Com exceção da Guiana e da Guiana Francesa, todos os demais países sul-americanos, Argentina, Bolívia, Brasil, Colômbia, Chile, Equador, Paraguai, Peru, Suriname, Uruguai e Venezuela, assinaram a Convenção ${ }^{55}$.

Neste evento, também foi apresentado uma lista de quatro categorias de áreas protegidas, a serem adotadas: Parque Nacional, Reservas de Regiões Virgens, Reserva da Fauna e da Flora ${ }^{56}$, e Monumento Natural, ficando de fora a Reserva com proibição para caça e coleta, listada na Convenção de Londres. Esta classificação perdurou até 1966, quando foi publicado uma lista de áreas protegidas, resultando do primeiro Congresso Mundial Parques Nacionais, realizado Seatlle (1962), como veremos.

No sentido de unificar o conceito, Parques Nacionais foram definidos como áreas que deveriam ser estabelecidas para a proteção e conservação das belezas cênicas naturais e da flora e fauna de importância nacional, das quais o público poderia aproveitar melhor, ao serem postas sob superintendência oficial ${ }^{57}$. O conceito apenas resume as características adotadas para a definição de Parques, adotadas na Convenção de Londres.

\subsubsection{A Criação da União Internacional para a Conservação da Natureza e dos Recursos Naturais - UICN (1948)}

Depois de oito anos da Convenção Pan-Americana, em 1948, foi criada a União Internacional para Proteção da Natureza (UIPN), a partir da proposta estabelecida em um congresso internacional organizado pelo governo francês e pela UNESCO, em Fontainebleau, França, onde participaram 33 países, entre eles o Brasil. Suas metas basearam-se principalmente na proteção do ambiente natural, coleta e análise de dados, informações e divulgação de pesquisas e legislação ${ }^{58}$.

A UIPN, sob patrocínio da UNESCO, foi composta por agências governamentais e entidades não governamentais, e tinha como objetivo a viabilização da promoção de ações com bases científicas, que pudessem garantir a perpetuidade dos

\footnotetext{
${ }^{54}$ Id., p. 15.

${ }^{55}$ AMEND \& AMEND, 1992 apud LEUZINGER, 2009; BRITO, 2003, p. 24.

${ }^{56}$ ALMEIDA, 2014, p. 23.

${ }^{57}$ QUINTÃO, 1983, p. 15. No Brasil, os termos da desta Convenção foram aprovados em 1948.

${ }^{58}$ LEUZINGER, 2009, p. 71, ARAÚJO, Marcos Antonio Reis. Unidades de Conservação no Brasil: da república à gestão de classe mundial. Belo Horizonte: SEGRAC, 2007, p.39.
} 
recursos naturais, vislumbrando não somente seus valores científicos intrínsecos, mas, sobretudo o bem estar econômico e social da humanidade ${ }^{59}$.

Ao longo dos anos, a busca pela conservação da biodiversidade caracterizou esse organismo internacional que, em 1956, passou a ser chamado de União Internacional para a Conservação da Natureza e dos Recursos Naturais (UICN). A União passou a colaborar intensivamente para a realização de pesquisas sobre a defesa da natureza, e propôs o primeiro sistema de classificação de áreas protegidas, fazendo distinção entre reservas naturais e zonas de proteção ${ }^{60}$.

Desde o início, estava previsto que a UICN deveria vincular pesquisas científicas com profissionais e gestores políticos. A ligação se daria com uma rede de biólogos ou zoólogos, que trabalhassem em instituições acadêmicas ou de pesquisa, funcionários técnicos e administradores de parques nacionais, zoológicos, aquários, e outras áreas protegidas ${ }^{61}$.

A seguir podemos constatar no Quadro 1, um breve histórico da União, desde a sua criação até a década de 1990.

Quadro 1 Histórico resumido da UICN: 1948 a 1993.

1948 Criação da União Internacional para Proteção da Natureza sob os auspícios da UNESCO.
1956 Alterou o nome para União Internacional para a Conservação da Natureza e dos Recursos
Naturais.
1959 Preparação de uma lista de Parques Nacionais e Reservas Equivalentes.
1961 Após contínuos anos de problemas financeiros, a UICN decide criar em paralelo o Fundo
Mundial para a natureza (World Wildlife Fund) - WWF, com foco da captação de recursos.
1969 Com ajuda da Fundação Ford, a UICN aumenta seu secretariado internacional.
1971 Publicação do relatório sobre Meio Ambiente e Desenvolvimento em preparação para a
Conferência de Estocolmo, em 1972.
1972 A UNESCO adota a Convenção sobre a Proteção do Patrimônio Natural e Cultural Mundial, e a
1974 UICN é convocada a fornecer avaliações técnicas e serviços de monitoramento.
cargo do Programa de Meio Ambiente das Naçães Unidas.
1975 Convenção sobre zonas úmidas de importância internacional.
1980 Publicação da Estrátegia de Conservação Mundial, com UNEP, WWF e colaboração da FAO e
UNESCO.
1982 A Assembleia Geral das Nações Unidas aprovou a Carta Mundial da Natureza, com base no
trabalho preparatório realizada pela UICN.

Fonte: CHRISTOFFERSEN, 1997, p. 60-61.

\footnotetext{
${ }^{59}$ QUINTÃO, 1983, p. 15.

${ }^{60}$ ARAÚJO, 2007, p.39.

${ }^{61}$ CHRISTOFFERSEN, 1997, p. 62.
} 
Em 1960 foi criada, na UICN, uma comissão que teria um papel fundamental nas atividades desenvolvidas nas décadas seguintes. Trata-se da Comissão de Parques Nacionais e Áreas Protegidas - CNPPA. Depois denominada World Commission on Protected Areas- WCPA, em português Comissão Mundial de Áreas Protegidas (CMAP).

Há mais de cinquenta anos a UICN e a CMAP têm atuado na defesa e criação de áreas protegidas, tendo como missão, promover a criação e gestão eficaz de uma rede mundial de áreas protegidas terrestres e marinhas. Entre seus objetivos podemos citar: defender as áreas protegidas através da prestação de consultoria estratégica para os formuladores de políticas; fortalecer a capacidade de eficácia dos gestores dessas áreas, com orientações, ferramentas e informações; aumentar os investimentos nas áreas, persuadindo os investidores públicos e corporativos de seu valor ${ }^{62}$.

Quando criada, a CMAP pretendia buscar novos critérios que atendessem à necessidade de proteção da biodiversidade, além daqueles estabelecidos nos objetivos dos primeiros Parques (que, como vimos, eram baseados na contemplação das belezas cênicas). A ideia era ampliar os limites espaciais das áreas protegidas, a fim de garantir o equilíbrio dos ecossistemas. A inserção dessa nova perspectiva de proteção de habitat dentro das áreas protegidas, deveu-se em parte à publicação de uma lista contendo uma série de espécies ameaçadas de extinção. Trabalho divulgado em 1960 com título Red Data Book ${ }^{63}$.

A Comissão passou a patrocinar eventos e conferências internacionais, que se tornaram norteadoras das políticas mundiais, quando o assunto eram as áreas protegidas. Citaremos aqui quatro importantes congressos mundiais sobre parques nacionais, que aconteceram a cada dez anos. O primeiro aconteceu em 1962 e foi sediado em Seatlle; o segundo em 1972 em Yellowstone, nos Estados Unidos; o terceiro em 1982, em Bali, na Indonésia e; o quarto em 1992, em Caracas, na Venezuela ${ }^{64}$. Também chamaremos a atenção para a ocorrência de eventos internacionais sobre questões ambientais, que mostram o fortalecimento dos movimentos ambientalistas.

Neste sentido, não podemos deixar de registrar que, em 1961, portanto antes do I Congresso Mundial de Parques Nacionais, nascia a World Wild life Fund - WWF, na

\footnotetext{
${ }^{62}$ World Commission on Protecte Areas - WCPA. Disponível em: http://www.iucn.org/about/work/programmes/gpap_home/gpap_wcpa/>. Acesso em: 09 dez. 2014. ${ }^{63}$ LEUZINGER, 2009, p. 71-72.

${ }^{64}$ ARAÚJO, 2007, p. 40. O quinto Congresso Mundial aconteceu em 2003, em Durban (África do Sul); e o sexto em Sidney em 2014 (Austrália), com o tema Parques, Pessoas, Planeta: inspirando soluções.
} 
Suíça. A WWF foi uma iniciativa internacional privada, que objetivava arrecadar fundos para financiar projetos para área ambiental. Logo após sua criação ela ficou responsável pelo levantamento junto a países ricos e organizações privadas de recursos financeiros para a realização de projetos. E, depois de ganhar autonomia, passou a financiar projetos de várias instituições. Logo se transformou em uma das organizações mais ativas no campo da conservação da natureza no mundo moderno ${ }^{65}$. Atualmente, com a mesma sigla, passou a denominar-se World Wide Fund for Nature. Para Soares, a intensa atividade das organizações não governamentais como entidades científicas, se espalharam pelo mundo, e conservaram o caráter internacional e sem fronteiras da pesquisa $^{66}$.

\section{a) O I Congresso Mundial de Parques Nacionais (1962) e as questões ambientais nos anos 1960.}

O I Congresso Mundial de Parques Nacionais foi realizado em Seattle, EUA, em 1962. O Tema do Congresso era "Os Parques Nacionais possuem significado internacional", e seu objetivo baseava-se na definição de padrões para sistemas representativos, conduzindo para uma lista das áreas protegidas, que englobava três categorias: Parque Nacional, Reserva Científica, e Monumento Natural ${ }^{67}$.

A Comissão Mundial de Áreas Protegidas organizou a primeira Lista Mundial de Parques e Reservas Equivalentes, discutindo-se também a nomenclatura apropriada para designar os vários tipos de áreas protegidas criadas no mundo até então ${ }^{68}$. Os principais temas de reflexão do congresso foram: a interpretação dos atributos dos parques nacionais, visando à educação ambiental; a restrição a alguns tipos de obras, como barragens; o planejamento e coordenação de pesquisas científicas; a necessidade de conservação dos ambientes marinhos; e a necessidade de se realizar o zoneamento dessas áreas ${ }^{69}$.

Dentre as recomendações deste congresso, ficou registrada a proposta de criação de áreas apropriadas ao habitat natural para cada espécie animal ou vegetal ameaçada de extinção, fossem elas na forma de Parque Nacional ou outro tipo de área

65 DORST, Jean. Antes que a Natureza Morra: por uma ecologia política. Tradução Rita Buongermino. São Paulo: Edgard Blücher, 1973, p. 110.

${ }^{66}$ SOARES, 2003, p. 20.

${ }^{67}$ ALMEIDA, 2014, p. 23.

${ }^{68}$ ARAÚJO, 2007, p.40.

${ }^{69}$ LEUZINGER, 2009, p. 72; QUINTÃO, 1983, p. 16. 
protegida. Destacando-se que, para cada espécie ameaçada que não encontrasse proteção, seria proclamado pela CMAP o fracasso do Governo envolvido ${ }^{70}$.

Com relação à possibilidade de utilização direta de recursos naturais dentro dos parques, o relatório do congresso declarou que, de forma excepcional e transitoriamente, para garantir direitos existentes antes de sua criação - como os de habitação, agricultura e pecuária, prospecção e caça - tais atividades poderiam ser permitidas desde que em pequenas áreas, buscando-se gradativamente sua finalização ${ }^{71}$.

A partir das recomendações apontadas no I Congresso Mundial de Parques Nacionais, ficou estabelecido um novo conceito para parques nacionais, aprovado pela X Assembléia Geral da UICN, em 1969 (realizada em Nova Delhi, na Índia). Na Assembléia ficou recomendado que todos os governos concordassem em utilizar o termo "Parque Nacional" para áreas que possuíssem, além de uma extensão relativamente grande, algumas características específicas. A saber: a) área onde um ou mais ecossistemas não estivessem materialmente alterados pela exploração humana; onde espécies de plantas e animais, ou sítios geomorfológicos e habitats fossem de especial interesse científico, educacional e recreativo, ou contivessem paisagens naturais de grande beleza; b) local para o qual a mais alta autoridade competente do país tivesse tomado medidas no sentido de prevenir ou eliminar a exploração ou ocupação de toda área, e mantivesse efetivamente os aspectos ecológicos, geomorfológicos ou estéticos que justificassem o estabelecimento da referida área; e c) área onde seria permitida a entrada de visitantes sob condições especiais, para fins de inspiração, educativos, culturais e recreativos ${ }^{72}$.

Neste sentido, as áreas que possuíssem características diferenciadas daquelas propostas pela X Assembléia Geral da UICN e que estivessem classificadas como "Parque Nacional" deveriam receber nova designação ${ }^{73}$. Vale salientar que, nesta Assembléia, evidenciou-se mais uma vez a idéia da incompatibilidade entre parques e populações residentes.

Ainda no final da década de 60 , foi realizada a nível internacional a Conferência Intergovernamental de Especialistas sobre as Bases Científicas para Uso e Conservação Racionais dos Recursos da Biosfera, conhecida mundialmente como

\footnotetext{
${ }^{70}$ QUINTÃO, op. cit., p. 16.

${ }^{71}$ AMEND \& AMEND apud LEUZINGER, 2009, p. 72.

72 QUINTÃO, op. cit., p. 16; LEUZINGER, op. cit., p. 72; BRITO, 2003, p.27; ARAÚJO, 2007, p.40.

${ }^{73}$ QUINTÃO, op. cit., p. 16-17.
} 
Conferência da Biosfera. Ela foi realizada em Paris, em 1968, e focou nos aspectos científicos da conservação da biosfera ${ }^{74}$.

Assim, quase duas décadas se passaram após a Convenção Pan-Americana, antes que fosse realizado um novo evento internacional sobre a temática ambiental. A Conferência da Biosfera, reuniu 64 países, 14 organizações intergovernamentais e 13 ONGS, e foi financiada com recursos de um conjunto de organismos internacionais: UNESCO, ONU, FAO, Organização Mundial de Saúde - OMS, IUCN e o International Biological Programme- IBP $P^{75}$.

Segundo Araújo, a conferência "abordou o uso e a conservação mais racional da biosfera, discutiu assuntos como a poluição do ar e da água, os desmatamentos, o excesso de monoculturas e a drenagem de áreas alagadas "76. Um dos temas debatidos na Conferência, foram os conflitos resultantes da exclusão de populações locais do processo de criação de áreas de proteção integral. Como resultado do evento, a UNESCO criou, em 1971, o Programa Homem e Biosfera (MaB - Man and the Biosfer $)^{77}$.

O programa era uma cooperação científica internacional, que buscava investigar as iterações entre o homem e seu meio, através do entendimento dos mecanismos dessa convivência, procurando avaliar as repercussões das ações humanas sobre os ecossistemas mais representativos do mundo ${ }^{78}$.

A Reserva da Biosfera seria uma área de proteção ambiental, mas onde seria tolerada a presença humana, cujo objetivo principal se baseava no equilíbrio entre as relações do homem com meio natural ${ }^{79}$. As primeiras reservas desta natureza foram estabelecidas em nível mundial em 1976, e em 2006 já estavam registradas cerca de 480 reservas da biosfera no mundo ${ }^{80}$.

Neste período, a comunidade internacional começou a se interessar pelos crescentes conflitos que envolviam populações residentes em áreas naturais protegidas. Como exemplo, pode-se destacar o desalojamento de grupos étnicos na África, para a

\footnotetext{
${ }^{74}$ McCORMICK, 1992, p. 97.

${ }^{75}$ RIBEIRO, 2010, p, 63. O International Biological Programme foi criado em 1964, contando com a participação de biólogos de vários países do mundo. Sua meta era produzir informações sobre os sistemas naturais e registrar as transformações que eles sofriam em decorrência da ação humana, em especial devido aos grandes acidentes ecológicos, como a chuva ácida, o derramamento de petróleo nos oceanos, a deposição de metais pesados em cursos d'água, dentre outros (Id., p, 71).

${ }^{76}$ ARAÚJO, 2007, p.41.

${ }^{77}$ Id.

${ }^{78}$ Ibid.

${ }^{79}$ LEUZINGER, 2009, p. 72-73.

${ }^{80}$ ARAÚJO, 2007, p.41.
} 
implantação áreas protegidas, fato que culminou em diversos conflitos que, em alguns casos, ainda permanecem ${ }^{81}$.

b) O II Congresso Mundial de Parques Nacionais (1972) e outros eventos dos anos 1970.

Com o tema "Parques Nacionais para o futuro", o principal objetivo do Congresso era a conservação de ecossistemas, origem do patrimônio mundial e convenção das terras húmidas ${ }^{82}$.

O II Congresso foi realizado em Yellowstone (EUA), em 1972, em comemoração ao centenário de criação do primeiro parque norte-americano. Neste evento, recomendou-se que todos os governos aumentassem a cobertura de suas áreas protegidas, de forma a assegurar que as amostras representativas dos biomas e ecossistemas naturais em todo o mundo, fossem conservadas num sistema coordenado de Parques Nacionais e áreas protegidas correlatas, e que a seleção e implantação destas áreas deveriam ser consideradas como elementos essenciais no planejamento regional do uso do solo ${ }^{83}$.

Para a escolha das áreas a serem protegidas, recomendou-se que deveria ser dada alta prioridade à conservação de biomas e ecossistemas terrestres e marinhos que ainda se encontravam sem perturbações, àqueles em perigo de desaparecerem totalmente, e àqueles que contivessem espécies ameaçadas e recursos genéticos importantes. Além disso, também se recomendou atenção especial para as florestas tropicais e campos, regiões polares, ecossistemas insulares e recifes de corais $^{84}$.

Neste congresso, problemas relativos à integridade dos Parques Nacionais foram tratados, e solicitou-se a todos os países que tomassem medidas efetivas para a proteção das áreas transformadas em unidades de conservação. Estratégias de planejamento para os parques também foram discutidas, como zoneamento, utilização de veículos, barcos e aviões, pesquisa, planejamento e treinamento de pessoal. Sobre a nomenclatura, solicitou-se que todos os países buscassem utilizar a definição de Parques Nacionais estabelecida pela IUCN em $1969^{85}$.

\footnotetext{
${ }^{81}$ BRITO, 2003, p. 28.

${ }^{82}$ ALMEIDA, 2014, p. 26.

${ }^{83}$ QUINTÃO, 1983, p. 17.

${ }^{84} \mathrm{Id}$.

${ }^{85}$ Ibid.
} 
No bojo dessas discussões surgiu o conceito de zoneamento, que foi incorporado às definições de parques nacionais, através da XI Assembléia Geral da UICN, de 1972, realizada em Banff (Canadá), ficando também reconhecido o direito de comunidades tradicionais residirem em áreas protegidas, como os parques ${ }^{86}$. Foram definidas onze zonas, formando três grandes grupos, a saber: Zonas Naturais Protegidas (Zona de Proteção Integral, Zona de Manejo de Recursos e Zona Primitiva ou Silvestre); Zonas Antropológicas Protegidas (Zona de Ambiente Natural com Culturas Humanas Autóctones, Zona com Antigas Formas de Cultivo e Zona de Interesse Especial); Zonas Protegidas de Interesse Arqueológico ou Histórico (Zona de Interesse Arqueológico e Zona de Interesse Histórico) ${ }^{87}$.

Através da introdução das zonas antropológicas no zoneamento dos parques, ficou reconhecido que comunidades tradicionais específicas integrariam os ecossistemas objetos de proteção ${ }^{88}$. Após três anos, essa temática ganhava mais fôlego na XII Assembléia Geral da UICN, que aconteceu no Zaire, em 1975, na qual foi enfatizada a questão da desagregação cultural e econômica de grupos tradicionais residentes em áreas de proteção integral, especialmente quando a presença destas populações não comprometia as condições ecológicas da unidade ${ }^{89}$.

Em 1975 a UICN, através da Comissão de Parques, começou um trabalho com vistas ao estabelecimento de um sistema internacional de classificação para as áreas protegidas. A equipe de trabalho foi liderada por Kenton Miller ${ }^{90}$, sendo o relatório final publicado em 1978. No trabalho, ficou mais claro o uso das terminologias utilizadas para as categorias de manejo. Foi proposto um sistema de dez categorias, não hierarquizadas e elencadas de acordo com seus objetivos de gestão.

No relatório, definiu-se que o sistema de categorização deveria abranger três critérios. Primeiro, as áreas protegidas deveriam se complementar; cada uma deveria desenvolver o seu sistema de categoria de manejo, de maneira que refletisse as

\footnotetext{
${ }^{86}$ RODRIGUES, 2005 apud LEUZINGER, 2009.

${ }^{87}$ BRITO, 2003, p. 30.

${ }^{88}$ LEUZINGER, 2009, p. 73.

${ }^{89} \mathrm{Id}$.

${ }^{90} \mathrm{O}$ americano Kenton Miller foi participante de uma geração de ambientalistas que lutou para o estabelecimento de áreas protegidas em todo o mundo. Durante décadas, seja como pesquisador ou como presidente da Comissão Mundial de Parques Nacionais da União Internacional de Conservação da Natureza (UICN), ou como Diretor Geral da UICN, ele contribuiu para criar sistemas nacionais de unidades de conservação e para melhorar a qualidade do seu manejo (O Planejador de Áreas Protegidas com Keton Miller. Entrevistadores: Maria Tereza Jorge Pádua e Marc Dourojeanni. Entrevista concedida ao site O ECO. Disponível em: http://www.oeco.org.br/reportagens/10979-oeco_26884. Acesso em: 04 de dez. 2014).
} 
necessidades de seu país; e por último, todas as nações deveriam trabalhar em conjunto com a UICN, com o objetivo de reunir e analisar dados sobre as áreas protegidas. Neste sentido, iria-se diminuir ou extinguir ambiguidades e contradições que dificultavam a nomenclatura das áreas. As áreas seriam classificadas de acordo com os objetivos de manejo, e estes objetivos seriam mantidos na gestão de cada área protegida ${ }^{91}$.

As dez categorias foram definidas pelo objetivo de gestão, todos considerados importantes, sem a proposição de categoria mais valiosa que outra. As categorias foram agrupadas em três grupos ${ }^{92}$ : Grupo A - Categorias que a CNPPA iria assumir especial responsabilidade - Reserva Científica/Reserva Natural Restrita, Parque Nacional, Monumento Natural/Monumento Nacional, Reserva de Recursos Naturais, Paisagem Protegida; Grupo B - Reserva de Recursos Naturais, Reserva Antropológica, Área Natural Manejada com Finalidade de Utilização Múltipla; Grupo C - Reserva da Biosfera, e Sítio Natural do Patrimônio Mundial ${ }^{93}$.

De acordo com Quintão, após o segundo congresso de parques, em 1972, houve uma década de grandes acontecimentos em todo o mundo, como a crise mundial de energia, a discussão de uma nova ordem econômica internacional, a explosão demográfica, entre outros eventos, que instigaram a reflexão sobre a conservação dos recursos naturais. Para o autor, tais transformações legitimaram o reconhecimento do papel dos Parques Nacionais e de outras áreas protegidas dentro do contexto conservacionista global ${ }^{94}$.

Em 1972 também aconteceu a Conferência das Nações Unidas sobre o Ambiente Humano, realizada em Estocolmo, Suécia, considerada um marco fundamental no desenvolvimento do ambientalismo mundial. De acordo com McCormick, nesta conferência foram discutidos pela primeira vez problemas políticos, sociais e econômicos do meio ambiente global ${ }^{95}$.

A decisão da Assembleia Geral da ONU em realizar esta Conferência surgiu da necessidade de discutir temas ambientais que poderiam gerar conflitos internacionais. De acordo com McCormick, esse assunto reuniu, em Estocolmo, 113 países, 19 órgãos intergovernamentais e 400 outras organizações intragovernamentais e não

\footnotetext{
${ }^{91}$ DUDLEY, 2008, p. 4.

${ }^{92} \mathrm{Id}$.

${ }^{93}$ DUDLEY, 2008, p. 4; ARAÚJO, 2007, p. 43; LEUZINGER, 2006, p. 75; IUCN. Guidelines for Protected Area Management Categories. Gland, Switzerland and Cambridge, UK.: CNPPA with the assistance of WCMC.IUCN, 1994. p. 5;

${ }^{94}$ QUINTÃO, 1983, p. 17.

${ }^{95}$ McCORMICK, 1992, p. 98.
} 
governamentais ${ }^{96}$. Entretanto, apenas dois chefes de Estado compareceram à reunião: Olaf Palme e Indira Gandhi, representando respectivamente a Suécia e a Índia ${ }^{97}$.

O Plano de Ação da Declaração de Estocolmo continha entre as suas metas, a avaliação do impacto ambiental e da educação sobre a importância da conservação; recomendações de combate à poluição; manutenção e recuperação de recursos naturais. Dentre outras, que serviriam como base para a elaboração de normas de proteção ao meio ambiente, no plano do direito interno dos vários países, e ainda constituiriam a base de tratados e das novas regras no plano internacional ${ }^{98}$.

Nesse percurso, o cenário internacional continha duas correntes opostas. A primeira, gerada por defensores do crescimento a qualquer preço, que viam a questão ambiental como um obstáculo colocado ao desenvolvimento econômico dos países do Hemisfério Sul; e a outra, defendida pelos denominados catastrofistas, que argumentavam em defesa do possível esgotamento dos recursos naturais do planeta como decorrência do acelerado crescimento demográfico e econômico ${ }^{99}$.

Os países da "periferia" defendiam o desenvolvimento, ainda que com ele viesse a poluição. Foi o que o representante do Brasil na ocasião argumentou: "Venham (as indústrias) para o Brasil. Nós ainda não temos poluição" ${ }^{100}$. Vários destes países tinham uma posição desenvolvimentista, pois achavam injusto não desenvolver-se tendo em vista os impactos ambientais causados pelos outros ${ }^{101}$. A China por exemplo, se manifestou a favor dos países periféricos, defendeu a autonomia dos países em relação à adoção de restrições ambientais, e criticou rigidamente as formulações neomalthusianas, apontando como principal responsável pela degradação ambiental a política neocolonialista protagonizada pelos países centrais no texto da Conferência ${ }^{102}$.

\footnotetext{
${ }^{96}$ Ibid., p.105

${ }^{97}$ RIBEIRO, 2010, p. 74. A temática ambiental só entraria na agenda de políticos em 1994, quando da realização da Conferência das Nações Unidas para Combater a Desertificação nos Países Seriamente Afetados pela Seca e/ou Desertificação, em especial na África (CD), realizada em Paris na qual registrouse uma presença marcante de chefes de Estado (Id., p. 83; 133).

${ }^{98}$ ELLIOT, Lorraine apud LEUZINGER, 2009, p. 74.

${ }^{99}$ ARAÚJO, 2007, p. 42.

${ }^{100}$ RIBEIRO, 2010, p. 80.

${ }^{101}$ Em um contexto da Guerra Fria no qual as superpotências respeitavam-se mutuamente, assistindo a manifestação de seus satélites. Os países do bloco socialista que integravam o então Leste Europeu, à época área de influência da URSS, não participaram da Conferência em protesto contra a intenção das Nações Unidas de não dar voto e voz à então Alemanha Oriental. Se o argumento político era forte, também é verdade que o chamado Leste Europeu era a região mais industrializada do bloco socialista. A recusa de participar os livraria da adesão às normas de controle de poluição do ar e os liberava para continuar a poluir (RIBEIRO, 2010, p. 81).

102 Id., p. 81.
} 
Frente à necessidade de viabilizar o Plano de Ação de Estocolmo, a ONU em Assembleia Geral, em 1972, decidiu criar o Programa das Nações Unidas para o Meio Ambiente - PNUMA. Sua implantação não foi fácil, os países que eram contra as regras estabelecidas na Conferência de Estocolmo eram também contra sua criação, acreditando que seria mais um instrumento para impedir o desenvolvimento e impor normas de controle ambiental adotadas pelos países centrais. A sede do PNUMA foi fixada em Nairobi, Quênia, onde passou a funcionar em 1973 de forma muito tímida ${ }^{103}$.

Também em 1972, sob os auspícios da Unesco, foi assinada em Paris, a Convenção para a Proteção do Patrimônio Mundial, Cultural e Natural. Quanto ao Patrimônio Natural, eram consideradas as formações físicas, biológicas e geológicas excepcionais, habitats de espécies animais e vegetais ameaçadas, e áreas que tivessem valor científico, de conservação ou estético ${ }^{104}$.

\section{c) O III Congresso Mundial de Parques Nacionais (1982) e outras iniciativas da UICN nos anos 1980.}

Durante a década de 1980, a UICN passar a ter uma visão mais diferenciada sobre as comunidades locais, em virtude da dificuldade em se promover a conservação da biodiversidade sem a anuência e a participação das mesmas, especialmente daquelas que já habitavam o interior das áreas protegidas implantadas ${ }^{105}$.

Em entrevista concedida a Fabiana Pureza de Almeida para sua pesquisa de mestrado, Claudio Carrera Maretti, explicou como a participação da população local era importante no contexto da conservação para $\mathrm{UICN}^{106}$ :

Então, já nos anos 80, nós começamos a perceber, eu ainda estava na Europa, uma certa preocupação na UICN com as chamadas comunidades locais depois chamadas comunidades tradicionais, sobretudo na Ásia e na África, menos na América Latina, porque começou a se perceber que era muito difícil se fazer conservação sem a anuência e a participação dessas

\footnotetext{
${ }^{103}$ Apesar dos esforços do primeiro Diretor Executivo, Maurice Strong, apenas onze anos depois de sua instalação, o PNUMA criou medidas de apoio à aplicação do Plano de Ação definido em Estocolmo: o Programa de Avaliação Ambiental Global - uma rede de informações destinadas a acompanhar os programas ambientais internacionais e nacionais; o Programa de Administração Ambiental - que visava a falta de determinação dos países em adotar medidas de conservação ambiental; Medidas de apoio - um amplo programa de capacitação de técnicos e professores com o objetivo de preparar pessoal para as práticas conservacionistas (Ibid., p. 82-83).

${ }^{104}$ ARAÚJO, 2007, p.42.

${ }^{105}$ ALMEIDA, 2014, p. 24.

${ }^{106}$ Entrevista do Geógrafo Claudio Carrera Marreti concedida a Fabiana Pureza de Almeida, em 15 de julho de 2013, em Brasília.
} 
comunidades locais que são as comunidades que vivem onde essas unidades são implantadas. Então, apesar das categorias da UICN serem muito amplas, elas consideravam a questão da cultura, mas sob o ponto de vista muito estático. Então, eram mais sítios arqueológicos, era tudo morto na verdade como o resto da natureza era meio selvagem. Começou a entrar pessoas que eram botânicos, biólogos, florestais na UICN e, algumas ainda estão até hoje lá, e criou-se uma unidade lá chamada grupos de estudos demográficos, na UICN, mas na verdade a preocupação inicial dentro desses grupos era ver se a presença dessas populações nessas áreas, aumentando como aumentam no terceiro mundo, não iam colocar em risco a conservação ${ }^{107}$.

No III Congresso Mundial de Parques Nacionais, ocorrido em Bali, em 1982, com o tema "O papel das Áreas Protegidas na sustentação da sociedade", enfatizou-se a conservação dos elementos vivos, e uma perceptível preocupação com as populações residentes em unidades de conservação, ficando recomendada a participação destas populações no manejo das unidades ${ }^{108}$. Segundo Vianna, o documento intitulado "The Bali Action Plan", recomendou:

Investigar e usar o conhecimento tradicional das comunidades afetadas pelas medidas de conservação, incluindo a implementação de gerenciamento conjunto entre as autoridades das áreas protegidas e as sociedades que tradicionalmente têm administrado os recursos"109.

Também foi discutido que, para se ter sucesso nos esforços conservacionistas, era necessário que houvesse avanços em outros setores relacionados com o da conservação. Devia-se assim considerar: a medida do padrão de vida das populações dos países em desenvolvimento, que eram forçadas por sua pobreza a explorar com mais intensidade os recursos naturais; a redução do superconsumo e desperdício de recursos naturais pelos mais abastados; o controle da poluição; a busca por uma redução mais rápida nas taxas de crescimento populacional, e a luta pelo desarmamento ${ }^{110}$.

Dentre as ações definidas na Declaração de Bali, pode-se destacar a luta pela expansão da rede global e regional de Parques Nacionais e outras áreas protegidas, que buscava assegurar a perpetuidade de ecossistemas únicos e representativos; pela maior parte possível da diversidade biótica da Terra, incluindo recursos genéticos silvestres; pelas áreas importantes para a pesquisa científica; e pelas áreas naturais de valor espiritual e cultural ${ }^{111}$.

\footnotetext{
${ }^{107}$ ALMEIDA, 2014, p. 24-25.

${ }^{108}$ LEUZINGER, 2009, p. 76. Em 1985, a ONU e a UICN, passaram a incluir em sua lista de parques nacionais, aqueles em que havia população tradicional residente.

${ }^{109}$ VIANNA, 2008, p. 159.

${ }^{110}$ QUINTÃO, 1983, p. 17.

${ }^{111}$ Id., p. 18.
} 
Vianna aponta que, a Comissão de Parques passou a enfatizar políticas que contemplassem a "criação e o manejo dos parques nacionais e de outras categorias de áreas naturais protegidas relacionadas ao desenvolvimento regional e estadual, as populações, os recursos naturais e o meio ambiente" ${ }^{112}$. Neste contexto, o autor percebe também uma preocupação em investigar e usar o conhecimento tradicional das comunidades afetadas pelas medidas de conservação, incluindo a implementação de gerenciamento conjunto entre as autoridades das áreas protegidas e as sociedades que tradicionalmente vinham administrando os recursos. Para a autora, essa consideração formaliza a mudança na percepção sobre os usuários tradicionais das áreas naturais protegidas, passando a considerá-los como manejadores dos recursos naturais ${ }^{113}$.

Em 1985, o livro intitulado Culture and Conservation, publicado pela UICN, discutiu uma série de conflitos envolvendo populações residentes em áreas protegidas, sugerindo ainda soluções para os problemas. Para tanto, foi destacado que a atribuição de importância e/ou valor às populações indígenas, em razão de seu conhecimento sobre os ecossistemas e de suas "práticas ecológicas", seria essencial para aos objetivos de conservação $^{114}$.

Já em 1986, a UICN lançou o manual Managing Protectecd Areas in the Tropics, onde defendeu que as áreas protegidas naturais eram essenciais para a conservação dos recursos vivos de uma nação, assegurando que amostras representativas de importantes regiões naturais fossem mantidas em perpetuidade, assim como a diversidade física e biológica, e que o material genético selvagem fosse conservado $^{115}$. O manual ainda dedicou um capítulo ao apoio às populações locais de áreas naturais protegidas, sugerindo que as mesmas deveriam ser vistas como instrumento diferenciado para o desenvolvimento regional, e não como um ônus, apontando inclusive a possibilidade destas populações utilizarem, desde que harmonicamente, determinados recursos das áreas naturais protegidas ${ }^{116}$.

O manual da UICN demonstrou que, além da conservação dos recursos vivos de uma nação, as áreas protegidas também poderiam contribuir para a preservação ambiental das áreas adjacentes, para a capacidade produtiva dos ecossistemas, para a

\footnotetext{
112 VIANNA, 2008, p.159.

${ }^{113}$ Id., p.159.

${ }^{114}$ Ibid., p. 159-160.

115 DIEGUES, 2008, p. 151.

116 VIANNA, 2008, p. 159.
} 
realização de pesquisas e educação ambiental, para o desenvolvimento rural integrado e ainda para o turismo e recreação ${ }^{117}$.

\section{d) O IV Congresso Mundial de Parques Nacionais (1992) e outros eventos dos anos 1990.}

Como vimos, desde a sua criação, a UICN através da Comissão Mundial de Áreas Protegidas, estabeleceu uma força-tarefa objetivando aprimorar o sistema de classificação das áreas protegidas no mundo.

O IV Congresso Mundial de Parques, foi realizado em Caracas, na Venezuela, e tinha como tema, "Parques para a Vida". Dentre os objetivos de discussão, destacaramse: as mudanças globais; as áreas protegidas, suas categorias e o efetivo gerenciamento das mesmas $^{118}$.

A proposta de nova categorização analisada no Congresso, baseou-se em nove objetivos de manejo: investigação científica; proteção de zonas silvestres; preservação de espécies e da diversidade genética; manutenção dos serviços ambientais; proteção de características naturais e culturais; turismo e recreação; educação; utilização sustentável ${ }^{119}$.

Consideramos importante, ressaltar que durante o IV Congresso, foi discutido a possibilidade de introduzir as Reservas Extrativistas dentro da classificação das áreas protegidas. Categoria proposta pelo movimento dos seringueiros no Brasil. Entretanto, esse debate só alavancou em 1994, durante o Congresso da UICN, realizado em Buenos Aires. Neste, foi produzido um relatório denominado Talking the same language: an international rewiw system for protected areas, sendo aprovado e publicado como Guidelines for Protected Area Management Categorias, momento em que foi incorporado a nova categoria ${ }^{120}$. Para Miller, o sistema de Categorias ofereceu uma maneira simplificada de comparar e contrastar os fundamentos e enfoques do manejo de unidades de conservação em todo o mundo ${ }^{121}$.

Assim, ficou recomendado um sistema de classificação composto por seis categorias de áreas protegidas: Reserva Natural Restrita/Área Silvestre - com fins

\footnotetext{
${ }^{117}$ DIEGUES, 2008, p. 151.

${ }_{118}$ ALMEIDA, 2014, p. 26.

119 ARAÚJO, 2007, p.43-44.

${ }^{120}$ ALMEIDA, 2014, p. 25.

${ }^{121}$ MILLER, 1997, p. 8.
} 
científicos ou com fins de proteção da natureza; Parque Nacional - para conservação de ecossistemas e com fins de recreação; Monumento Natural - para a conservação de características naturais específicas; Santuário de Vida Silvestre - para a conservação de habitats e/ou para satisfazer as necessidades de determinadas espécies; Paisagem Terrestre/Marinha Protegida - para conservação de paisagens terrestres e marinhas com fins recreativos; e Área Protegida com Recursos Manejados - para uso sustentável dos ecossistemas naturais ${ }^{122}$.

Além da publicação das seis categorias de áreas protegidas, vigentes até os dias atuais, o termo "áreas protegidas" foi definido como: "uma superfície de terra elou mar especialmente consagrada à proteção e manutenção da diversidade biológica, assim como dos recursos naturais e patrimônio cultural associados, e gerida através de meios jurídicos ou outros meios eficazes" ${ }^{\prime 23}$.

A matriz de objetivos de gestão (conforme Tabela 2, em anexo) e categorias de gestão das áreas classificadas em 1994, segundo Miller, poderia servir de instrumento para ajudar os planejadores de parques, e outras partes interessadas, a selecionar a melhor categoria, de acordo com os objetivos de gestão que desejassem para determinada área. Dessa maneira, se o objetivo predominante fosse manter a biodiversidade silvestre, o planejador poderia apontar para as categorias de parque nacional ou outras que atendessem tais características. Por outro lado, se a intenção fosse manter a paisagem domesticada, onde certos recursos pudessem ser explorados e a colonização humana também fizesse parte de uma forma ordenada, o planejador poderia escolher, por exemplo, a categoria Área Protegida com Recursos Manejados ${ }^{124}$.

Ainda no IV Congresso ficou estabelecido que os países deveriam buscar atingir uma meta de que $10 \%$ da área de seus territórios fossem cobertos por unidades de conservação até o ano de 2000. O que, na opinião de Brito, seria uma meta aparentemente difícil de ser atingida, tendo em vista "a improbabilidade de o poder público vir a dispor de recursos para adquirir terras ou regularizar aquelas que estão nos limites de algumas unidades de conservação já criadas"125.

\footnotetext{
122 IUCN, 1994, p. 7.

${ }^{123}$ CHAPE, Start; BLYTH, Simon; FISH, Lucy FO, Phillip and SPALDING, Mark (compilers). United Nations List of ProtectedAreas. IUCN, Gland, Switzerland and Cambridge, UK and UNEP-WCMC, Cambridge, UK, 2003, p. 2.

${ }^{124}$ MILLER, 1997, p. 8-9.

${ }^{125}$ BRITO, 2003, p. 94. É valido destacar que o IV Congresso Mundial de Parques Nacionais, foi o último a fazer alterações nas categorias de áreas protegidas. O V Congresso aconteceu em Durban, África do Sul, em 2003, tendo como tema "Benefícios além da fronteira". Os objetivos pautaram-se nos temas sobre
} 
Ainda em 1994, foi criado o Banco Mundial de Áreas Protegidas (WDPA World Database on Protected Areas), por inciativa conjunta da UICN e do Centro de Monitoramento Mundial para Conservação, que tinha por objetivo fornecer informações sobre todas as áreas protegidas em nível mundial. De acordo com Corrigan at. al., de início o WDPA “apresentava uma listagem básica dos Parques Nacionais mundiais, mas atualmente é uma das únicas fontes de informações sobre parque e áreas protegidas em âmbito global",126.

Apesar de não tratar exclusivamente da questão das áreas protegidas, vale ressaltar ainda que, na década de 1990 foi realizada a Conferência das Nações Unidas para o Meio Ambiente e o Desenvolvimento - CNUMAD. A decisão de realizar esta Conferência foi definida em Assembléia Geral das Nações Unidas, ainda em 1988, momento em que as preocupações pautavam-se no desenvolvimento aliado à conservação ambiental. A Conferência foi sediada no Brasil, na cidade do Rio de Janeiro, em 1992.

Uma das justificativas para se realizar a conferência no Brasil estava ligada à devastação da Amazônia e ao assassinato do líder sindical Chico Mendes, em 1988. A manifestação de grupos ambientalistas, que denunciaram os dois episódios, sensibilizara os delegados presentes à Assembléia Geral da ONU de $1989^{127}$. Era um momento delicado, pelo qual a região amazônica passava. No Acre, por exemplo, os incentivos do governo federal para a ocupação da região, geraram muitos conflitos pela posse da terra, entre seringueiros, (que viviam há décadas na região) e os novos "donos" (que compraram as terras), provenientes do centro-sul do país. Os conflitos, resultaram em violência sangrenta. Muitos seringueiros foram mortos, bem como alguns compradores de terras (fazendeiros).

Do ponto de vista da mobilização de lideranças políticas, a CNUMAD foi um sucesso. Participaram 178 Estados-nação, dos quais 114 chegaram a ser representados pelos respectivos Chefes de Estado. Dentre os quais podemos destacar lideranças dos países ricos, como George Bush (Presidente dos EUA), François Mitterrand (Presidente da França) e John Major (Primeiro Ministro da Inglaterra) e, como frisou Ribeiro, expoentes dos países em desenvolvimento, como Fidel Castro (Presidente de Cuba). A participação da sociedade civil organizada, através das ONGs, também foi outro dado

governança, finança sustentável, capacidade de desenvolvimento, conexão das paisagens terrestre e marinhas, equidade e benefícios (ALMEIDA, 2014, p. 26.).

${ }^{126}$ CORRIGAN, at. al. 2011 apud ALMEIDA, 2014, p. 26.

${ }^{127}$ RIBEIRO, 2010, p. 107. 
importante a ser considerado. De acordo com Ribeiro, pela primeira vez na história da ONU, em uma reunião envolvendo Chefes de Estado, a influência das ONGs resultou na inclusão de alguns temas na pauta de negociações ${ }^{128}$.

O objetivo da Conferência foi o estabelecimento de acordos internacionais que mediassem as ações antrópicas no ambiente. Tratou-se das mudanças climáticas globais e do acesso e manutenção da biodiversidade, na forma de Convenções Internacionais. Como resultado, foram elaboradas duas declarações, a Declaração Rio (uma carta de princípios pela preservação da vida na Terra) e a Declaração de Florestas (que estabelecia a intenção de manter as florestas), além da Agenda XXI, um plano de ação que visava minimizar os problemas ambientais mundiais ${ }^{129}$

\subsection{Algumas Considerações sobre o processo de criação, a nível mundial, de áreas protegidas.}

Como vimos, o Parque Nacional de Yellowstone, criado em 1872 nos Estados Unidos, foi um marco moderno da proteção de áreas naturais contra o avanço das atividades humanas consideradas degradadoras da natureza. Tendo sido criado quando da expansão da fronteira agropecuária e mineral em direção ao oeste do EUA.

Devemos ressaltar que o primeiro conceito de Parque Nacional, foi definido com a criação do Parque de Yellowstone, sendo uma área natural selvagem, que não tivesse nenhuma ação antrópica. Os objetivos do primeiro parque legalmente protegido, baseou-se na beleza cênica e proteção da vida selvagem, na tentativa de manter remanescentes intocados. A presença humana era permitida apenas para contemplação. Este fato, têm demonstrado até hoje, a dificuldade no manejo dos parques em todo o mundo, pois quando são criadas, obedecem a regulamentação dos Parques Nacionais, que demonstra certa distância na relação homem e natureza.

Infelizmente esta visão preservacionista, não impediu que a degradação continuasse nos EUA, e em outros países. E o modelo foi gradativamente se espalhando pelo mundo, em um contexto dicotômico entre povos e parques. Estilos de vida de populações "tradicionais" foram desconsiderados, mantendo o padrão de visão urbana, ao considerar que os elementos naturais, como montanhas, florestas, e vida selvagem

\footnotetext{
${ }^{128}$ Id., p. 108.
}

129 Ibid. 
formam um conjunto que é considerado "natureza", e deve portando ser mantida sem a presença dos seres humanos.

Entretanto, o renomado pesquisador Antônio Carlos Diegues, têm demostrado em suas publicações que esse modelo de Parques, se baseiam em um mito, o da natureza intocada. Neste ínterim, aparecem os conflitos entre as estratégias de conservação da natureza e os povos residentes nessas áreas. E como já frisado, essas populações também são tidas como responsáveis pela manutenção da diversidade biológica, segundo a pesquisadora Nurit Bensusan.

As convenções internacionais citadas neste capítulo deram o ponta pé inicial para o processo de categorização e criação de áreas protegidas em todo o mundo. Mas, o grande destaque foi a criação, em 1946, da União Internacional para a Conservação da Natureza e dos Recursos Naturais. Congregando órgãos governamentais, ONG's, pesquisadores e outros interessados, tendo como meta principal a proteção dos recursos naturais.

Ao criar a Comissão Mundial de Áreas Protegidas, em 1960, a UICN pretendia aperfeiçoar os critérios para atender a necessidade de proteção dos recursos naturais. A Comissão, passou a organizar os Congressos Mundiais de Parques Nacionais, com periodicidade de dez anos. Foi possível perceber que em cada Congresso realizado, novos objetivos eram destacados para proteção da biodiversidade, através das novas categorizações das áreas protegidas.

Quando da criação da primeira área legalmente protegida, o Parque Nacional de Yellowstone, tínhamos um único objetivo de manejo, que pautava-se na proteção da vida selvagem (wilderness), sendo permitido as pessoas apenas a contemplação da beleza cênica do lugar. Com a evolução das categorias de áreas protegidas, os países puderam criar diferentes tipos de áreas, com objetivos e manejo específicos, algumas permitindo inclusive a presença de moradores.

O gráfico a seguir, nos permite observar o ritmo do crescimento das áreas protegidas no mundo, de acordo com a publicação da Lista de Áreas Protegidas, de 2014, do Banco Mundial de Áreas Protegidas. 


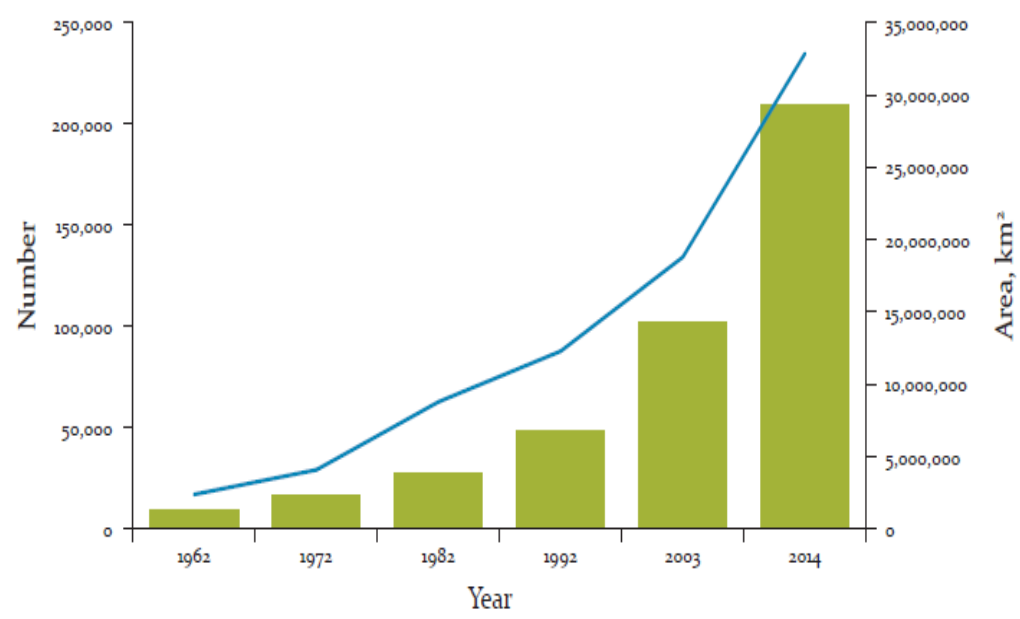

Gráfico 1 Valor cumulativo para o número e a área ocupada pelas áreas protegidas terrestres e marinhas no período de 1962 a 2014.

Fonte: DEGUIGNET al. at., $2014^{130}$.

O número de áreas protegidas desde o primeiro congresso mundial de parques, cresceu positivamente. Em 1962, o número de áreas era de 9.214, cobrindo 2.400.000 $\mathrm{km}^{2}$. Conforme os dados de 2014, o número de áreas pulou para 209.429, protegendo mais de $32.000 .000 \mathrm{~km}^{2}$.

Consideramos positivo o trabalho da UICN no processo de categorização das áreas protegidas, pois não foi estabelecido divisões hierárquicas entre as várias categorias. Como salientou Diegues, todas as áreas devem apresentar a mesma importância, mesmo aquelas que preveem a presença humana ${ }^{131}$.

Informações do site da UICN, mostram que a União hoje "se apoia na valorização e preservação da natureza, garantindo uma governança eficaz e equitativa de utilização, e na busca de soluções para os desafios globais do clima, alimentação e desenvolvimento”. Para tanto, apoia a investigação científica, gerencia projetos de campo em todo o mundo, através de parcerias com governos, organizações não governamentais e empresas, para que possam trabalhar em conjunto no desenvolvimento de políticas, leis e melhores práticas.

É a maior e mais antiga organização ambiental do mundo, com mais de 1.200 membros, incluindo mais de 200 governos e mais de 900 organizações não governamentais. Estão associados mais de 11.000 cientistas e especialistas voluntários agrupados em seis Comissões, com cerca de 160 países. Os trabalhos da União são apoiados por mais de 1.000 funcionários, em 45 escritórios e, centenas de parceiros dos

${ }^{130}$ DEGUIGNET, Marine et. al. União Nations List of Protected Areas. UNEP-WCMC: Cambridge, UK, 2014, p. 14.

${ }^{131}$ DIEGUES, 2008, p. 121. 
setores público, privado e ongs em todo o mundo. Sua sede está localizada em Gland, perto de Genebra, na Suíça, e recebe financiamentos de governos, agências bilaterais e multilaterais, fundações, organizações membros e corporações ${ }^{132}$.

Quadro 2 Visão e Missão da União Internacional para a Conservação da Natureza e dos Recursos Naturais

\section{Visão e Missão da UICN}

Visão: um mundo justo que valoriza e preserva a natureza.

Missão: influenciar, encorajar e ajudar as sociedades de todo o mundo a conservar a integridade e a diversidade da natureza e garantir que o uso dos recursos naturais seja equitativo e ecologicamente sustentável.

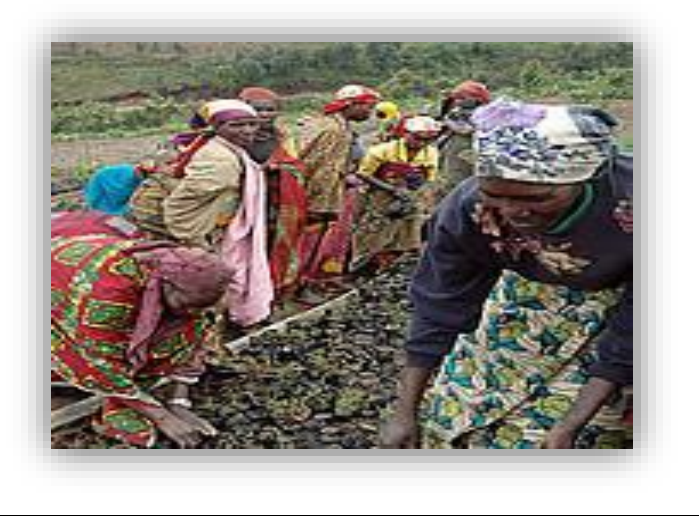

Fonte: International Union for Conservation of Nature, 2014.

Atualmente (2014), a IUCN atua por meio de seis comissões, que unem mais de 10.000 especialistas voluntários das mais diversas áreas do conhecimento. As comissões são: Commission on Educationand Communication - CEC, com mais de 1.200 membros; Commission on Environmental, Economic and Social Policy - CEESP, com 1.465 membros; World Commission on Environmental Law - WCEL, com 800 membros; Comission on Ecosytem Managemente - CEM, com 1000 membros; Species Survival Commission - SSC, com 7.500 membros e; a World Commission on Protected Areas - WCPA, com mais de 1.700 membros.

Não podemos deixar de comentar que estudos mais recentes sobre os Parques mostram algumas incertezas sobre a criação destes, em áreas de diversidade biológica alta ou única, que a princípio era vista como prioridade, para que a flora e a fauna locais não fossem ameaçadas. Uma premissa considerada chave que estaria implícita nessa abordagem era a de que as áreas protegidas iriam manter indefinidamente as espécies nelas contidas inicialmente ${ }^{133}$.

\footnotetext{
${ }^{132}$ International Union for Conservation of Nature. About IUCN. Disponível em http://www.iucn.org/about/. Acesso em: 09 dez. 2014.

${ }^{133}$ TERBORGH, John. A arca de Noé ou porque precisamos de parques. Natureza \& Conservação. v. 1, n. 2, p. 9-15, out. 2003, p. 09-10.
} 
Entretanto, o artigo publicado por Newmark (aluno de doutorado da Universidade de Michigan) revelou que essa premissa poderia ser refutável. Sua pesquisa sobre a situação de grandes mamíferos, nos parques nacionais do oeste norteamericano, demonstrou que o processo de extinção desses animais foi maior nos parques pequenos, quando comparado aos parques com grandes áreas de extensão. As perdas foram contínuas ao longo do tempo, mesmo com a forte proteção das áreas analisadas $^{134}$.

Tabela 1 Perda das principais espécies de mamíferos dos parques nacionais do oeste norte-americano estudadas por Newmark.

\begin{tabular}{l|c|c|c|c}
\hline \multicolumn{2}{|c}{$\begin{array}{c}\text { Área } \\
\text { Parque }\end{array}$} & \multicolumn{1}{c}{$\begin{array}{c}\text { Idade } \\
\text { (anos) }\end{array}$} & $\begin{array}{c}\text { Espécies de } \\
\text { mamíferos } \\
\text { perdidas* }\end{array}$ & $\begin{array}{c}\text { Proporção de espécies } \\
\text { originais perdidas }\end{array}$ \\
\hline Bryce Canyon & 144 & 61 & 5 & $36 \%$ \\
Lassen Volcanic & 426 & 77 & 6 & $43 \%$ \\
Mount Ranier & 976 & 85 & 7 & $32 \%$ \\
Rock Mountain & 1.049 & 69 & 2 & $31 \%$ \\
Yosemite & 2.083 & 94 & 4 & $25 \%$ \\
Yellowstone & 10.328 & 83,5 & 1 & $4 \%$ \\
Jasper-Yoho & 20.736 & 84,5 & 0 & $0 \%$ \\
\hline
\end{tabular}

*Desde o aparecimento do parque Fonte: TERBORGH, 2003, p. 10.

Analisando os dados da tabela, entendemos que para criar áreas protegidas de uso indireto, como é o caso dos Parques, não basta só encontrarmos uma área que apresente uma diversidade biológica alta ou única, é necessário um estudo mais aprofundado do tamanho necessário que determinadas espécies, animais ou vegetais necessitam para não serem extintos.

Por fim, o estudo de Newmark nos mostra que só o fato de criar estas áreas não garante a conservação de espécies, é preciso estabelecer princípios específicos de conservação. As extinções não são inevitáveis, mas o planejamento e o manejo são necessários para preveni-las.

134 TERBORGH, op. cit., p. 9-10. 


\section{CAPÍTULO 2}

\section{Gênese e Evolução das Unidades de Conservação no Brasil: 1930 a 2000}

Para falarmos da implantação do Parque Nacional da Serra do Divisor-AC, objeto de estudo deste trabalho, entendemos que se faz necessário realizarmos uma análise do cenário ambiental nacional. Destacando: a atuação de alguns estudiosos que deram início ao alerta sobre a questão ambiental no país; o surgimento de políticas públicas de proteção dos recursos naturais; e as primeiras áreas protegidas implantadas no país.

A implantação dessas áreas pode ser considerada uma estratégia importante na defesa de um território, pois elas são espacialmente bem delimitadas e nelas são definidas dinâmicas de uso e ocupação específicas, com valorização dos recursos naturais existentes e proteção de biomas, ecossistemas e espécies raras ou ameaçadas de extinção $^{135}$.

Quando analisamos a implantação do sistema brasileiro de unidades de conservação, percebemos que a época de criação e a sua distribuição geográfica estiveram intimamente ligadas a diferentes etapas do processo de desenvolvimento do país e que, entre outras questões, foram fortemente marcadas pelo avanço das frentes pioneiras sobre regiões ainda consideradas "virgens" ou "inabitadas". Na opinião de Quintão, ao mesmo tempo que o desenvolvimento impulsionou a criação de áreas naturais protegidas, de forma contraditória este mesmo desenvolvimento ameaçava a existência das áreas já existentes ${ }^{136}$.

A literatura que tem se voltado para a presença de conceitos preservacionistas no Brasil, em geral considera que a primeira ideia de criação de parques partiu de André Rebouças, no final do século XIX. Reconhecido pelas suas várias competências (engenheiro, político, professor, abolicionista e empreiteiro do setor madeireiro), Rebouças se inspirou nos primeiros parques norte-americanos, sugerindo que se protegesse a Ilha do Bananal, no atual estado de Tocantins, e a região de Sete Quedas, no Paraná ${ }^{137}$. Suas propostas foram publicadas em 112 páginas de um trabalho, que

\footnotetext{
${ }^{135}$ MEDEIROS, Rodrigo. Evolução das Tipologias e Categorias de Áreas Protegidas no Brasil. Ambiente \& Sociedade, São Paulo, v. 9, n. 1, p. 41-64, jan./jun. 2006. p. 41. ${ }^{136}$ QUINTÃO, 1983, p. 13.

137 LEUZINGER, 2009, p.87; QUINTÃO, 1983, p. 15; BRITO, 2003, p.53; DRUMMOND, Jose Augusto. National parks in Brasil: a study of 50 years of environmental policy (With Case Studies of
} 
trazia a sugestão de criação de parques no território brasileiro ${ }^{138}$. Apesar dos esforços de Rebouças, a criação de Parques Nacionais no país se concretizou apenas em 1937, com a implantação do Parque Nacional de Itatiaia, no Rio de Janeiro ${ }^{139}$.

Alguns autores também têm destacado a atuação de cientistas, como Ladislau de Souza Neto, diretor geral do Museu Nacional, de 1875 a 1893, e João Barbosa Rodrigues, diretor do Jardim Botânico nos anos 1890. Estas instituições, durante o século XIX, atuavam como centros de pesquisa, contribuindo para o avanço do conhecimento sobre a natureza brasileira ${ }^{140}$.

O período da República, também, tem chamado a atenção dos estudiosos. Neste sentido, vale lembrar que a Constituição republicana federal, de 1891, incluía um primeiro dispositivo referente à questão ambiental porém, de forma ainda tímida. $\mathrm{O}$ inciso XXIX do artigo 34, atribuía competência à União para legislar sobre minas e terras $^{141}$. Porém, não concedia ao Estado o direito de atuar amplamente sobre todo o patrimônio natural, agindo como órgão controlador e protetor do uso, exploração da flora, da fauna, das águas etc.

A literatura também tem destacado a atuação de cientistas no período da Primeira República. Franco ${ }^{142}$ e Drummond ${ }^{143}$, em artigo publicado em 2004, analisaram as ideias de um grupo de cientistas e escritores que, segundo eles, contribuíram para a formação de um pensamento brasileiro no tocante a questão ambiental. Em São Paulo, destacam Orville Derby, F. W. Dafert, Hermann Von Ihering, Alberto Loefgren e Edmundo Navarro de Andrade. Segundo os autores, estes naturalistas foram contratados por alguns setores do Partido Republicano paulista que começaram a se dar conta "dos riscos representados pela agricultura de plantation e

the National Parks of the State of Rio de Janeiro). 438f. Dissertation (Masters in Environmental Studies Program), The Evergreen Satte College, Olympia, Washington, 1988, p. 58.

138 MORSELLO, Carla. Áreas Protegidas Públicas e Privadas: seleção e manejo. $2^{a}$ ed. São Paulo: Annablume, 2008, p. 153.

${ }^{139}$ DRUMMOND, 1997, p. 144.

${ }^{140}$ FRANCO, José Luiz de Andrade e DRUMMOND, José Augusto. Preocupações com a proteção à natureza e com o uso dos recursos naturais na Primeira República brasileira. Textos de História, v, 12, n. $1 / 2$, p. 145-165, 2004, p. 146-47.

${ }^{141}$ LEUZINGER, 2009, p. 87.

${ }^{142}$ Assessor Técnico da Diretoria de Áreas Protegidas da Secretaria de Biodiversidade e Florestas, do Ministério do Meio Ambiente (2004-2005). Desde 2009 é professor Adjunto do Departamento de História da Universidade de Brasília.

${ }^{143}$ De 1978 a 2000 foi Professor Adjunto da Universidade Federal Fluminense-UFF, depois foi para o Centro de Desenvolvimento Sustentável da Universidade de Brasília, onde trabalha com professor Associada até os dias de hoje. 
pelo crescimento desordenado das cidades para o futuro da economia e manutenção do seu projeto político" ${ }^{144}$.

Ainda em relação à Primeira República, também tem sido dado destaque à publicação, em 1911, do "Mapa Florestal do Brasil", visto como o primeiro esforço mais significativo do governo brasileiro, no sentido da criação de áreas protegidas. A publicação do mapa foi de responsabilidade do cientista brasileiro Luíz Felipe Gonzaga de Campos, que trabalhou na escala de 1:5.000.000, trazendo descrições dos ecossistemas brasileiros, bem como seus estágios de conservação. A idéia era que este trabalho fundamentasse a criação de um conjunto de Parques Nacionais, como já vinha acontecendo em outros países ${ }^{145}$.

Após a publicação do "Mapa Florestal do Brasil", foi sugerida a criação de uma área de Reserva Florestal no, ainda, Território do Acre ${ }^{146}$, que foi legalmente instituída pelo Decreto Federal no 8.843, de 26 de julho de 1911, abrangendo cerca de 2,8 milhões de hectares, sob jurisdição do Ministério da Agricultura, Indústria e Comércio $^{147}$.

De acordo com o Decreto, a decisão do governo federal em instituir uma reserva florestal na região se deu em resposta à devastação desordenada das florestas, que estava produzindo, em todo o país, efeitos sensíveis e desastrosos. Com destaque para as alterações no clima e no regime das águas pluviais. Reconhecia-se, assim, a necessidade de impedir que tal devastação se ampliasse no Território acreano, o que poderia causar problemas na navegação fluvial e possíveis modificações no regime hidrológico. Entretanto, a proposta de criação da reserva caiu em total esquecimento, e a unidade jamais foi implantada.

Franco \& Drummond consideram que, em termos cronológicos, o grupo atuante na Primeira República se situava entre dois outros grupos de pensadores assemelhados. O primeiro atuante desde o fim do período colonial até a passagem do

\footnotetext{
${ }^{144}$ FRANCO e DRUMMOND, 2004, p. 147. As ferrovias paulistas, em forte expansão em termos de quilometragem e de cargas transportadas, representavam um símbolo da acelerada modernização e do avanço rápido das fronteiras cafeicultoras e da consequente extinção das formações vegetais nativas.

145 MEDEIROS, Rodrigo. A Proteção da Natureza: das estratégias internacionais e nacionais às demandas locais. 391f. Tese (Doutorado em Geografia). Rio de Janeiro: Instituto de Geociências, Departamento de Geografia, 2003, p. 85.

${ }_{146}$ MORSELLO, 2008, p. 152.

${ }^{147}$ BRASIL. Decreto n. 8.843, de 26 de julho de 1911. Cria a reserva florestal no Território do Acre. Rio de Janeiro: 1911.
} 
império para a república; e o segundo atuante entre 1930 a $1940^{148}$. Sobre o primeiro grupo, destacam o estudo pioneiro de José Augusto Pádua ${ }^{149}$.

Com relação ao segundo grupo podemos destacar o estudo realizado por José Luiz de Andrade Franco, em sua tese de doutorado, considerada a primeira análise mais detalhada da produção de um grupo de cientistas que atuou entre as décadas de 1920 e 1940 e que, na sua maioria, hoje estão esquecidos. O grupo era formado basicamente por cientistas afiliados ao Museu Nacional do Rio de Janeiro, que foram responsáveis por um grande volume de pesquisas e publicações sobre a questão da proteção à natureza no país. Entre eles, Franco destacou Alberto José Sampaio, Armando Magalhães Corrêa, Cândido de Melo Leitão e Frederico Carlos Hoehne ${ }^{150}$.

Ao mencionar os cientistas que atuaram do final do século XIX aos anos 1940, Franco e Drummond, tinham como foco contribuir para divulgar o pensamento de um grupo cronologicamente intermediário, ainda pouco estudado, "que deram valiosas contribuições à formação de um pensamento sobre a proteção à natureza no país" "151. Também valorizados por Leuzinger, como "cientistas e pensadores políticos conservacionistas, que apontavam preocupações quanto ao aproveitamento dos recursos naturais ${ }^{\prime 152}$.

O período que vamos aqui considerar começa nos anos 1930, quando foi criado o primeiro Parque Nacional. Para melhor contextualizar a evolução das Unidades de Conservação $^{153}$ (UC's), resolvemos fazer uma análise com base nos períodos que marcaram a história política do país. Para tanto, foi realizado levantamento detalhado das UC's criadas no Brasil, a partir dos decretos publicados, e foram comparados com os dados do Instituto Chico Mendes de Conservação da Biodiversidade - ICMBio ${ }^{154}$. Todas as informações das unidades de conservação identificadas no período de 1930 a

${ }^{148}$ FRANCO e DRUMMOND, 2004, p. 145-146.

149 José Augusto Pádua: "Um sopro de destruição: pensamento político e crítica ambiental no Brasil escravista (1786-1888)", publicado em 2004. Neste livro, Pádua examinou a produção de cerca de cinquenta autores preocupados com o estado da natureza e com os usos dos recursos naturais no país. Pádua seguia o caminho já aberto pelo historiador inglês Richard Grove, que estudara as antigas áreas coloniais inglesas. Segundo Franco e Drummond (2004, p.146), tanto Grove quanto Pádua encontraram ricas manifestações de preocupação com a natureza, muito anteriores às formulações modernas $\mathrm{e}$ contemporâneas mais conhecidas, divulgadas a partir de meados do século XX.

${ }^{150}$ FRANCO, José Luis Andrade. A primeira conferência brasileira de proteção à natureza e a questão da identidade nacional. Revista Varia História, Dossiê História e Natureza, Belo Horizonte: Departamento de História UFMG, n. 26, p. 77-96, 2002; FRANCO e DRUMMOND, 2004, p. 146.

${ }^{151}$ FRANCO e DRUMMOND, 2004, p. 146.

152 LEUZINGER, 2009, p. 87.

153 Unidade de Conservação é o termo utilizado no Brasil, a partir de 1970, para designar "área protegidas" (utilizada em nível internacional).

${ }^{154}$ O ICMBio está ligado ao Ministério de Meio Ambiente, e cabe a ele propor, implantar, gerir, proteger, fiscalizar e monitorar as UC's instituídas pela União. 
2000 foram organizadas em tabelas, contendo informações detalhadas como: decreto de criação, tamanho em hectares, localização nos estados e, biomas que fazem parte.

Nossa proposta foi dividir o período estudado em três sub-períodos, o que nos aproxima da análise feita pela arquiteta Ângela Tresinari B. Quintão, em $1983^{155}$, e pelo biólogo Marcos Antonio Reis Araújo, em 2007 ${ }^{156}$. O primeiro sub-período, de 1930 a 1964, começa na década de criação do primeiro Parque Nacional, cobrindo o período getulista e os governos civis dos anos 1950, terminando com o golpe militar. Como veremos, a maioria das unidades criadas neste período localizaram-se na porção leste do país, tendo sido escolhidas pela beleza cênica do local, concentração populacional e por possuírem maiores informações sobre seus recursos naturais. Só no final do período estas áreas foram se direcionando para a porção Oeste do país, acompanhando o fluxo migratório para Brasília e regiões adjacentes.

O segundo sub-período corresponde ao contexto do regime militar, de 1964 a 1985. Uma fase marcada tanto pelo autoritarismo político, como pelas políticas de ocupação da região amazônica, considerada até então "inabitada".

Por último, o terceiro sub-período, que teve início com a redemocratização do país, passando pela aprovação da nova Constituição de 1988, indo até 2000. Neste ano foi aprovada a Lei n. 9.985 de 18 de julho, que implantou o Sistema Nacional de Unidades de Conservação (SNUC).

\subsection{Políticas públicas ambientais e a criação das primeiras áreas protegidas no Brasil: 1930-1964}

\subsubsection{A Evolução das Políticas Públicas Ambientais}

As primeiras áreas legalmente protegidas instituídas pelo governo federal brasileiro surgiram na década de 1930. Esta década foi um período marcado pelos projetos de mudança e modernização do Governo de Getúlio Vargas, que se traduziram na instituição de novas leis trabalhistas e incentivos à industrialização. Também foi um período caracterizado pelo centralismo administrativo e por intenso nacionalismo. Segundo Franco, temas como trabalho, indústria, educação, saúde, base jurídico-

\footnotetext{
${ }^{155}$ QUINTÃO, 1983.

156 ARAÚJO, 2007.
} 
institucional, patrimônio histórico e proteção da natureza estiveram, então, presentes nos debates ${ }^{157}$.

A literatura aponta, também que, este foi o período do início da formação do sistema brasileiro de proteção à natureza, sendo, então, implementadas normas que regulamentavam o uso de determinados recursos naturais, como as florestas, as águas e os minérios. Medeiros e Leuzinger, por exemplo, falam que, durante o governo de Vargas, idéias e práticas de proteção do ambiente natural começaram a adquirir consistência, e o estímulo à criação de Parques Nacionais constituiu-se em um dos meios para garantir a preservação de áreas naturais dotadas de rara beleza ${ }^{158}$.

A evolução dessas áreas não foi contínua, sofreu variações ao longo dos anos, estando sempre aliada ao contexto político, localização geográfica e aos critérios utilizados para a seleção dos locais onde seriam implantadas ${ }^{159}$. De acordo com Drummond, as pressões para a criação das primeiras áreas protegidas no Brasil partiram de setores da comunidade científica que estavam mais próximos do governo federal ${ }^{160}$. Já Medeiros destaca a ação de movimentos voltados à questão ambiental, que começavam a se organizar, influenciados pelo ideário preservacionista norte-americano, conseguindo estimular os poderes executivo e legislativo na luta pela proteção da natureza $^{161}$

A primeira iniciativa concreta de proteção das florestas veio com a aprovação do Código Florestal Brasileiro ${ }^{162}$, de $1934^{163}$, o primeiro do país, publicado justamente um ano após a Convenção para Preservação da Fauna e Flora em Estado Natural, realizada em Londres, em 1933, como vimos no capítulo 1. Pelo Código, as florestas existentes no território nacional foram consideradas um bem de interesse comum a todos os habitantes. Elas foram classificadas em quatro categorias: protetoras,

\footnotetext{
${ }^{157}$ FRANCO, 2002, p. 26.

${ }^{158}$ MEDEIROS, 2003, p. 87; LEUZINGER, 2009, p.88.

${ }^{159}$ DRUMMOND, 1988, p.14.

${ }^{160}$ Id., p.16.

${ }^{161}$ MEDEIROS, 2003, p. 86.

162 BRASIL. Decreto n. 23.793, de 23 de janeiro de 1934. Aprova o código florestal. Rio de Janeiro: 1934.

${ }^{163}$ Além do Código Florestal, foram aprovados mais dois códigos em 1934: o de Águas, através do Decreto $n^{\circ}$ 24.643, e o de Minas, Decreto $n^{\circ} 24.642$, ambos publicados em de 10 de julho. Anteriormente ao Código das Águas e de Minas, foi instituído o Código de Caça e Pesca, através do Decreto no 23.672 de 2 de janeiro de 1934, que posteriormente foi desmembrado em Código de Pesca (Decreto-lei $\mathrm{n}^{\circ} 794$ de 19 de outubro de 1938) e Código de Caça (Decreto-lei no 5.894 de 20 de outubro de 1943). Os códigos de caça e pesca, determinaram a criação dos Parques de Reserva, Refúgio e Criação de Animais Silvestres, categorias de áreas protegidas inclusas na tipologia Parques de Criação e Refúgio de Animais.
} 
remanescentes, modelos, e de rendimento. E foi especificamente nas classificadas como remanescentes, que entraram os Parques Nacionais ${ }^{164}$.

Os parques foram definidos como monumentos públicos naturais que pudessem perpetuar, em sua composição florística primitiva, trechos do país que, por circunstâncias peculiares, merecessem ser preservados ${ }^{165}$. Além da definição de parques, também foram estabelecidas restrições para o uso dessas áreas, destacando-se a proibição rigorosa do exercício de qualquer atividade que modificasse o equilíbrio natural da flora e a fauna.

Também foi criado, no âmbito do Código Florestal, um Conselho Federal Florestal, instância máxima da política florestal do país e que estava sediado no Ministério da Agricultura. O Conselho era formado por representantes do Museu Nacional do Rio de Janeiro, do Jardim Botânico do Rio de Janeiro, da Universidade do Rio de Janeiro, do recém-criado Serviço de Fomento da Produção Vegetal (ligado ao Ministério da Agricultura), do Departamento Nacional de Estradas, do Serviço Federal Florestal $^{166}$ e do Touring Club do Brasil (única entidade privada), além de quatro especialistas, que deviam ser funcionários públicos ${ }^{167}$. O Conselho Federal Florestal exerceu importante papel quando da escolha das áreas onde se situariam os primeiros parques nacionais do Brasil, além de estabelecer critérios para várias atividades comerciais ligadas aos produtos florestais.

Ainda em 1934, entre 8 e 15 de abril, ocorreu a Primeira Conferência Brasileira de Proteção à Natureza, realizada na cidade do Rio de Janeiro. Durante a Conferência, falou-se bastante das experiências conservacionistas norte-americanas conhecidas pelos brasileiros, tanto no campo da silvicultura quanto no estabelecimento

\footnotetext{
${ }^{164}$ As classificadas como "protetoras" eram aquelas indicadas para conservar o regime das águas, evitar a erosão das terras, fixar dunas, auxiliar a defesa das fronteiras, assegurar condições de salubridade pública, proteger as belezas naturais e manter espécies raras. As do tipo "modelo" seriam aquelas artificiais, constituídas apenas por uma, ou por limitado número de essências florestais, indígenas e exóticas, cuja disseminação fosse conveniente para a região, para fins comerciais. As demais, diga-se de passagem, a imensa maioria, eram consideradas produtivas, ou seja, sujeitas à exploração comercial.

165 BRASIL. Decreto n. 23.793, de 23 de janeiro de 1934. Aprova o código florestal. Rio de Janeiro: 1934.

${ }^{166}$ DRUMMOND, José Augusto. A legislação ambiental de 1934 a 1988: comentários de um cientista ambiental simpático ao conservacionismo. Ambiente \& Sociedade, ano II, n. 3 e 4, p. 127-149, $2^{\circ}$ sem/ 1998, $1^{\circ} \mathrm{sem} / 1999$, p. 134. Um primeiro Serviço Federal Florestal foi criado em 1921 no Rio de Janeiro, para organizar a parte florestal da exploração brasileira e dedicar-se à arborização das ruas da cidade do Rio. O novo Serviço (criado em 1938), no ano de 1944, passou a ter uma Seção de Parques Nacionais, constituído de um pequeno grupo de funcionários e técnicos que administrou os parques brasileiros até 1967. Depois os parques passaram a ser administrados pelo Instituto Brasileiro de Desenvolvimento Florestal (IBDF).

${ }^{167}$ DRUMMOND, 1998/1999, p. 134.
} 
de parques nacionais ${ }^{168}$. De acordo com Franco, este evento influenciou na mobilização e no tipo de pensamento dos participantes presentes, das organizações da sociedade civil e das instituições públicas que estavam preocupadas com a questão ambiental e, especialmente, com a conservação da natureza ${ }^{169}$.

A Conferência foi organizada pela Sociedade dos Amigos das Árvores ${ }^{170}$, contando com apoio e infraestrutura do Museu Nacional, e tendo como relator, Alberto José Sampaio (botânico e professor do Museu) ${ }^{171}$. Na seção de abertura, o discurso do Presidente da Sociedade, Leôncio Corrêa, tratou da importância dos debates sobre o problema florestal e, entre outras coisas, elogiou o governo federal pela aprovação do Código Florestal ${ }^{172}$

Durante a Conferência também foram mencionados diversos congressos internacionais, experiências que estavam acontecendo em outras regiões do mundo, assim como leis de outros países que, segundo os presentes, estavam mais avançados no tocante a proteção da natureza ${ }^{173}$.

Quanto à criação de Parques Nacionais, podemos destacar três notas apresentadas na Conferência. O primeiro destaque foi para o resumo de um artigo de Edgard Roquette-Pinto ${ }^{174}$, denominado "Parques Nacionais", no qual André Rebouças era mencionado pelo seu projeto de instituir parques nacionais ainda no século XIX, aos moldes do Parque de Yellowstone. O autor recomendava ao governo a criação de parques, ressaltando a importância da criação dessas áreas como centros de pesquisa científica e de proteção da fauna e flora, além de suas funções recreativas, educativas e culturais $^{175}$.

O artigo da professora Ada Pereira da Fonseca, intitulado "Parque Nacional" foi o segundo destaque. Ela recomendava a criação dessas áreas de proteção ambiental, no caso, parques no Rio de Janeiro e também em outras regiões do país. Em sua opinião

\footnotetext{
${ }^{168}$ FRANCO, 2002, p. 83.

169 Id., p. 78.

${ }^{170}$ Organização não Governamental fundada no Rio de Janeiro em 1931 por Alberto José Sampaio.

${ }^{171} \mathrm{O}$ evento contou com a participação da Associação Brasileira de Educação, da Federação Brasileira pelo Progresso Feminino, da Liga Brasileira de Higiene Mental, da Associação Brasileira de Farmacêuticos, da Academia Brasileira de Ciências, do Instituto Histórico de Ouro Preto, do Instituto Histórico e Geográfico do Brasil, da Sociedade de Amigos de Alberto Torres, do Tijuca Tennis-Club, do Instituto Nacional de Música, da Associação dos Empregados no Comércio do Rio de Janeiro, e da Sociedade Fluminense de Medicina Cirúrgica, contando ainda com o patrocínio do, então chefe do governo provisório, Getúlio Vargas (FRANCO, 2002, p. 78-79).

172 FRANCO, 2002, p. 80.

173 Id., p. 83.

${ }^{174}$ Roquette-Pinto atuou nas áreas da Antropologia e da Radiodifusão e foi diretor do Museu Nacional.

${ }^{175}$ FRANCO, 2002, p. 87.
} 
o parque nacional era concebido como obra artística onde, além de se promover a proteção da natureza, buscava-se agrupar os vários tipos de árvores das diferentes regiões do país, para que se ampliasse o estudo na área da silvicultura e do paisagismo, além de garantir o reflorestamento ${ }^{176}$.

E por último, o destaque foi para uma notícia publicada pelo professor Auguste Chevalier, do Museu de História Natural de Paris, no suplemento da revista L'Afrique Française, em 1934, sobre a Convenção para a Proteção da Fauna e da Flora em Estado Natural, que trazia a proposta de conservação da fauna e flora com interesse estético e científico e não somente com objetivo utilitário ${ }^{177}$.

Como vemos os participantes da Conferência mostravam estar informados sobre as reuniões internacionais relacionadas à proteção ambiental e sobre os temas em debate.

Ainda nos anos 1930, vale ressaltar que a Constituição Federal de 1937, decretou como responsabilidade da União, proteger as belezas naturais e monumentos de valor histórico do país afirmando, em seu artigo 134, que os monumentos históricos, artísticos e naturais gozariam de proteção e cuidados especiais da Nação, dos estados e municípios ${ }^{178}$.

Já no início da década de 1940 foi criado o Instituto Nacional do Pinho (1941), órgão federal que representava os interesses dos produtores, industriais e exportadores de pinho. O instituto tinha sede na Capital da República, mas tinha representações dos governos dos estados do Paraná, Santa Catarina e Rio Grande do Sul $^{179}$. Dentre as várias ações do Instituto, pode-se destacar sua contribuição no reflorestamento das zonas produtoras do pinho, que deu origem a Parques Florestais nas regiões Sul e Sudeste do país e que, posteriormente, no final da década de 1960, passaram a se denominar Florestas Nacionais ${ }^{180}$.

Pensando ainda nas florestas, o novo Serviço Florestal, criado em 1938, no Ministério da Agricultura, teve seu regimento aprovado em 1944. O Serviço Florestal tinha sob sua responsabilidade promover a criação, fomento, proteção e a melhor

\footnotetext{
176 Id., p. 87-88.

177 Ibid., p. 88.

${ }^{178}$ DIEGUES, 2008, p. 115-116.

179 BRASIL. Decreto-Lei n. 3.124, de 19 de março de 1941. Cria o Instituto Nacional do Pinho e dá outras providências. Rio de Janeiro, 1941.

${ }^{180}$ BRASIL. Ministério da Agricultura. Portaria n. 561, de 25 de outubro de 1968. Rio de Janeiro: 1968.
} 
utilização das florestas do país ${ }^{181}$. Também, através de sua Seção de Parques e Florestas Nacionais, passou a administrar e fiscalizar todas as áreas de proteção criadas no âmbito do Código Florestal de 1934. O Serviço Florestal passou assim a ter o encargo de orientar, coordenar, fiscalizar, coordenar e elaborar programas de trabalho para os Parques Nacionais, além de promover a criação de parques federais, estaduais e municipais ${ }^{182}$.

Quanto ao alinhamento do governo brasileiro aos acordos internacionais na área da preservação ambiental, convém lembrar que, apesar da participação do país na Convenção Panamericana de 1940 (o diplomata brasileiro assinou o acordo em 27 de dezembro de 1940), foi somente após o fim da Segunda Guerra, que o Poder Executivo brasileiro ratificou o acordo, através do Decreto 58.054 de 1946. No entanto, como lembra Drummond, esta adesão foi meramente formal, pois foi implementada apenas em 1966 $6^{183}$. Pelo acordo, ficariam estabelecidos no país, quatro tipos de áreas protegidas: Parque Nacional, Reserva Nacional, Monumento Natural e Reserva de Região Virgem ${ }^{184}$.

Nos anos de 1950, aprofundou-se a inserção do Brasil na economia mundializada, os processos de industrialização se intensificaram, acelerando os impactos socioambientais ${ }^{185}$. Foi, então, privilegiada a implantação de grandes projetos de infraestrutura, produção agropecuária intensiva para exportação, e a exploração mineral ${ }^{186}$.

\footnotetext{
${ }^{181}$ BRASIL. Decreto n.16.677, de 29 de setembro de 1944. Aprova o Regimento do Serviço Florestal do Ministério da Agricultura. Rio de Janeiro: 1944. O Decreto lei n. ${ }^{\circ}$ 982, de 23 de dezembro de 1938, criou o Serviço Florestal.

${ }^{182}$ BRASIL. Decreto n.16.677, de 29 de setembro de 1944. Aprova o Regimento do Serviço Florestal do Ministério da Agricultura. Rio de Janeiro: 1944.

${ }^{183}$ DRUMMOND, 1998/1999, p. 135. O autor lembra que os acordos internacionais tendem a ter uma tramitação muita lenta, pois todas as ações ambientais que dependam de uma ou mais nação devem passar pelos trâmites tradicionais da diplomacia.

${ }^{184}$ As áreas eram assim definidas: 1) Parque Nacional: caracterizado por regiões estabelecidas para a proteção e conservação das belezas cênicas naturais da flora e da fauna de importância nacional das quais o público poderia aproveitar-se melhor se fossem postas sob a superintendência oficial; 2) Reserva Nacional: regiões estabelecidas para conservação e utilização das riquezas naturais que também protegeriam a fauna e a flora tanto quanto compatível com os fins para os quais essas reservas fossem criadas; 3) Monumento Natural: caracterizavam regiões, objetos, ou espécies de animais ou plantas, de interesse estético ou valor histórico ou científico, com proteção absoluta, com exceções para a realização de investigações científicas autorizadas; 4) Reserva de Região Virgem: neste caso, tratava-se de uma região administrada pelo poder público, onde existissem condições primitivas naturais de flora, fauna, habitação e transporte, com ausência de caminhos para o tráfego de veículos e onde fosse proibida toda exploração comercial (BRITO, 2003, p. 57; ARAÚJO, 2007, p.38-39).

185 VIANNA, 2008, p. 167.

186 Id., p. 167-168.
} 
Neste contexto, Tereza Urban coloca a criação, por um grupo de cientistas brasileiros, de uma organização privada bastante ativa nas décadas seguintes: a Fundação Brasileira para a Conservação da Natureza (FBCN, 1958), que tinha sede no Rio de Janeiro. Para a autora, a criação da fundação, além de evidenciar os laços destes cientistas com o movimento conservacionista internacional, tinha como objetivo enfrentar, de modo organizado, os apelos desenvolvimentistas do governo de Juscelino Kubitschek ${ }^{187}$.

A FBCN teve como modelo as associações de defesa das aves de Londres, sendo formada por um grupo bastante variado, com a participação de botânicos, zoólogos, jornalistas e pessoas interessadas, idealistas. Todos com a preocupação de disciplinar a ação do homem, para impedir uma maior devastação da natureza no país ${ }^{188}$.

Os ativistas desta Fundação tinham como objetivo promover uma ação nacional para a conservação dos recursos naturais e para a implantação de áreas reservadas de proteção à natureza ${ }^{189}$. Neste sentido, a Fundação devia atuar no estímulo e desenvolvimento de atividades como: a criação e estabilização de parques, reservas, monumentos e semelhantes, com especial atenção para as espécies raras ou ameaçadas de extinção; cooperação entre os governos e as organizações nacionais, estrangeiras e internacionais, preocupadas com a conservação da natureza e dos recursos naturais; realização de estudos e pesquisas relacionadas à conservação dos recursos naturais; difusão dos conhecimentos conservacionistas ${ }^{190}$. Apesar dos vários encontros e debates realizados, os primeiros anos da Fundação foram, aparentemente, pouco produtivos.

A FBCN continuou ativa nos anos 1960, e durante os governos de Juscelino Kubitschek e Jânio Quadros - influenciou, mesmo que de forma indireta ${ }^{191}$, a criação de

\footnotetext{
${ }^{187}$ URBAN, Tereza. Saudade do Matão: relembrando a história da conservação da natureza no Brasil. Curitiba: Editora da UFPR; Fundação O Boticário de Proteção à Natureza; Fundação MarArthur, 1998, p. 89. Franco e Drummond também comungam da opinião de Urban. Para eles, a Fundação representou um estímulo para se enfrentar de maneira organizada as propostas do governo federal de avançar cinquenta anos em cinco (FRANCO, Luiz de Andrade \& DRUMMOND, José Augusto. O Cuidado da Natureza: a Fundação Brasileira para a Conservação da Natureza e a experiência conservacionista no Brasil: 19581992. Textos de História, vol. 17, n. 1, p. 59-84, 2009, p. 63).

${ }^{188}$ Entre os membros fundadores estavam Artur Miranda Bastos, Eurico Santos, Francisco Iglesias de Lima, Fuad Atala, Haroldo Strang, Luiz Hermany Filho, Rosalvo Magalhães, Rossini Pinto, Victor Abdennur Farah e Wanderbilt Duarte de Barros (URBAN, 1998, p.89).

${ }^{189}$ FRANCO e DRUMMOND, 2009, p. 62.

${ }^{190}$ Boletim Informativo FBCN, n. 1, Rio de Janeiro, 1996. p. 2.

${ }^{191}$ A ação da FBCN se deu através de um de seus fundadores e primeiro diretor-executivo, Victor Abdennur Farah, que em naquele período estava como presidente do Conselho Florestal Federal.
} 
vários parques nacionais, além da elaboração do anteprojeto de lei que instituiu o novo Código Florestal de $1965^{192}$.

No entanto, não podemos perder de vista que, nestes anos, a criação de Unidades de Conservação foi de inteira responsabilidade do governo federal, mais especificamente do Ministério da Agricultura. Este Ministério, além de classificar as regiões para a formação de parques, através do Serviço Florestal cuidava da implantação e seguimento do Código Florestal.

\subsubsection{A criação das primeiras Unidades de Conservação: 1937-1961}

Com base em nossos levantamentos, as três primeiras áreas protegidas criadas na década de 1930 no país, se localizaram na região sudeste e eram da categoria Parque Nacional. Ao consideramos todas as áreas ambientalmente protegidas pelo poder público brasileiro, os parques constituem, assim, a categoria mais antiga.

Segundo a literatura, além dos fatores naturais contemplados na região sudeste, como beleza cênica, outros fatores tiveram forte influência na criação dessas unidades. A colonização mais antiga e a concentração populacional, por exemplo, possibilitaram maior quantidade de informações a respeito dos recursos naturais existentes, informações estas bastante precárias nas outras regiões do país, ainda pouco habitadas ${ }^{193}$.

Segundo Drummond, quando se iniciou o processo de criação dos Parques, o Brasil estava entre os países com maiores extensões de fronteiras geoeconômicas ou “áreas virgens", adequadas para a criação de parques nacionais, padrão adotado inicialmente por países como EUA, Canadá, Costa Rica, URSS, Chile e Argentina. Nestes países, a ideia era criar Parques em áreas remotas, de preferência àquelas que não tivessem sofrido alterações causadas pela agricultura, indústria ou urbanização ${ }^{194}$.

No entanto, apesar dos parques brasileiros atenderem aos mesmos objetivos iniciais dos norte-americanos - que se baseavam na contemplação da beleza cênica, na reflexão espiritual e no lazer - estes parques não foram estabelecidos em regiões

\footnotetext{
${ }^{192}$ Entre 1966 a 1989, a FBCN vivenciou momentos de auge. Suas comissões técnicas estiveram ativas e a instituição tinha cerca de 4.000 afiliados. Foram vários os projetos e trabalhos desenvolvidos na área de conservação de espécies raras ou ameaçadas de extinção, criação e implementação de áreas protegidas e a educação ambiental. Onze núcleos foram criados sob sua coordenação, espalhados por vários Estados. Alguns deles, na década de 1980, deram origem a novas ONGs de orientação conservacionista, como a Biodeversitas (Belo Horizonte), e a Funatura (fundada por Maria Tereza Jorge Pádua, em Brasília).

${ }^{193}$ QUINTÃO, 1983, p. 21.

${ }^{194}$ DRUMMOND, 1997, p. 147.
} 
consideradas remotas ou inabitadas. Eles foram implantados literalmente em regiões já bastante habitadas, em áreas do litoral, seguindo depois para o interior do país, em áreas com maior concentração populacional e que já estavam bem destruídas pela ação antrópica.

Castro Jr, Coutinho e Freitas salientaram que, enquanto "os parques americanos buscavam proteger as paisagens de um impacto futuro, os parques brasileiros buscavam proteger áreas de interesse ambiental de impactos imediatos, de conflitos já existentes" $" 195$.

Iremos observar ao longo do capítulo que o surgimento das unidades de conservação acompanhou o processo de ocupação nacional, seguindo a frente pioneira. O que fica claro quando lembramos as datas de criação das primeiras unidades em cada região, é que elas partiram do litoral para o interior do país: a primeira na região sudeste ocorreu em 1937 (Parque Nacional do Itatiaia); no centro-oeste, em 1959 (Parque Nacional do Araguaia); e, na região amazônica, em 1974 (Parque Nacional da Amazônia).

Cunha e Coelho argumentam neste sentido, afirmando que o crescimento da população de forma acelerada e concentrada na faixa litorânea do país, juntamente com a necessidade de reestruturar a ocupação, conduziram à criação de unidades de conservação voltadas para a proteção das manchas restantes da Mata Atlântica ${ }^{196}$.

No período de 1937 a 1948 foram criados quatro Parques e uma Floresta Nacional, abrangendo uma área de 262.401,92 hectares, o equivalente a 2.624,01 km². Das cinco áreas criadas, três delas se concentraram nas regiões Sudeste e Sul, bioma da Mata Atlântica, e duas na região Nordeste, bioma da Caatinga (ver detalhes na Tabela 3 em anexo).

Confirmando o que Drummond argumentou, sobre a atuação de cientistas na escolha da localização de muitos parques e reservas, temos a criação do Parque Nacional de Itatiaia, em 1937, região estudada por dezenas de cientistas desde o início do século XIX, e que foi criado pela sua beleza cênica, singularidade geológica, geomorfológica e biológica ${ }^{197}$.

\footnotetext{
195 CASTRO Jr., COUTINHO e FREITAS, 2009, p. 39.

196 CUNHA, Luís Henrique; COELHO, Maria Célia Nunes. Política e Gestão Ambiental. In: CUNHA, Sandra Baptista da; GUERRA, Antonio José Teixeira (Orgs). A Questão Ambiental: diferentes abordagens. 8. ed. Rio de Janeiro: Bertrand Brasil, 2012. p.43-79. p. 47.

${ }^{197}$ DRUMMOND, 1988, p.16. O Itatiaia, primeiro Parque criado pelo governo federal, estava localizado em terras adquiridas ainda em 1908, para fins de colonização agrária.
} 
Considerado uma medida efetiva de proteção da natureza, o parque tinha como objetivo defender a natureza da Serra do Itatiaia (denominação de uma seção da Serra da Mantiqueira), à altura dos municípios de Resende, no Rio de Janeiro, e Aiuruoca, Liberdade e Itamonte, no Estado de Minas Gerais ${ }^{198}$.

De acordo com o Decreto de criação $\mathrm{n}^{\circ} 1.713$ de 14 de junho de 1937, foi estabelecida uma área de 11.943 hectares $^{199}$, região em sua maioria coberta por vegetação primitiva, com altitudes variando entre 816 e 2.787 metros, cortada por numerosos pequenos córregos, apresentando uma flora diferenciada da de outras montanhas do país, região já estudada em todos os seus aspectos físicos e botânicos por cientistas nacionais e estrangeiros ${ }^{200}$.

O Decreto também assinalou a importância científica da área, além de considerar as finalidades de ordem turística, recomendando condições adequadas para atrair viajantes nacionais e internacionais. Assim, a região do Itatiaia foi considerada importante para a proteção da natureza, como auxílio às ciências naturais, incremento das correntes turísticas, e reserva de florestas para as gerações vindouras, reunindo todos os objetivos que justificavam a implantação de um parque naquele momento ${ }^{201}$. Seguiu os princípios estabelecidos em áreas protegidas nos EUA, especialmente no tocante à proteção de belezas cênicas e o usufruto público. Também, suas formações rochosas e sua localização na porta de entrada da capital federal, conduziam a um "retiro ideal" para o usufruto da população visitante e também dos cientistas ${ }^{202}$.

O segundo parque a ser criado foi o Parque Nacional do Iguaçu, em 1939203, localizado no município de Foz do Iguaçu, Estado do Paraná, a princípio com o intuito de proteger um trecho fronteiriço à República Argentina, em área que o governo do Estado cedeu ao poder Federal. Inicialmente foi estipulada uma área de 3.000,00 hectares para o parque (a área protegida era suficiente apenas para proteger a porção de terras mais próximas às cataratas), espaço 25 vezes menor que o do Parque Nacional

\footnotetext{
198 BARROS, Wanderbilt Duarte de. Parques Nacionais do Brasil. Rio de Janeiro: Ministério da Agricultura/Serviço de Informação Agrícola, 1952, p. 16.

${ }^{199}$ Em 1982, a área do parque foi ampliada para 30.000,00 ha (BRASIL. Decreto n. 87.586, de 20 de setembro de 1982. Amplia a área do Parque Nacional de Itatiaia, criado pelo Decreto n. 1.713, de 14 de janeiro de 1937 e dá outras providências. Brasília: 1982).

${ }^{200}$ BRASIL. Decreto n. 1.713, de 14 de junho de 1937. Cria o Parque Nacional do Itatiaia. Rio de Janeiro: 1937.

${ }^{201} \mathrm{Id}$.

${ }^{202}$ DIEGUES, 2008, p. 115.

${ }^{203}$ BRASIL. Decreto n. 1.035, de 10 de janeiro de 1939. Cria o Parque Nacional de Iguaçu e dá outras providências. Rio de Janeiro: 1939.
} 
Del Iguazú, na Argentina ${ }^{204}$. No entanto, a proteção do ecossistema local também era um dos objetivos da criação do parque: o artigo $3^{\circ}$ do Decreto de criação definia que os objetivos do parque não eram diferentes dos outros já estabelecidos, baseando-se na proteção das terras, da flora, da fauna e das belezas naturais ${ }^{205}$. Entre os motivos do aproveitamento paisagístico da área, estavam as notáveis cachoeiras dos rios Paraná e Iguaçu.

No mesmo ano, foi criado o Parque Nacional da Serra dos Órgãos, o terceiro parque do Brasil, por meio do Decreto $\mathrm{n}^{\circ} 1.822$ de 30 de novembro ${ }^{206}$, situado na região da Serra dos Órgãos, em terras dos municípios de Teresópolis, Magé e Petrópolis, no Rio de Janeiro. A princípio, o Parque abrangeu uma área de 10.000,00 hectares, e os objetivos de sua criação foram semelhantes aos do Parque de Iguaçu, ressaltando a importância florística, a majestosa topografia e beleza orográfica ${ }^{207}$ da região ${ }^{208}$.

Em 1946, foi criada a primeira Floresta Nacional do Brasil, Araripe-Apodi, situada no bioma da Caatinga, por meio do Decreto-Lei n. 9226 de 2 de maio. Foram estabelecidas duas glebas distintas, sendo uma na Serra do Araripe, na região dos Estados do Ceará, Pernambuco e Piauí; e outra na Serra do Apodi, entre os Estados do Ceará e Rio Grande do Norte ${ }^{209}$, abrangendo uma área de 38.331 hectares $^{210}$.

${ }^{204}$ BARROS, 1952, p. 61. Em 1981, o governo federal definiu novos limites para o território do parque, abrangendo 185.262,5 ha, área já acrescida em 1944 pelo Decreto n. 6.587, de 14 de junho (BRASIL. Decreto n. 86.676, de $1^{\circ}$ de dezembro de 1981. Fixa novos limites do Parque Nacional do Iguaçu no Estado do Paraná. Brasília: 1981).

${ }^{205}$ BRASIL. Decreto n. 1.035, de 10 de janeiro de 1939. Cria o Parque Nacional de Iguaçu e dá outras providências. Rio de Janeiro: 1939.

${ }^{206}$ BRASIL. Decreto-lei n. 1.822, de 30 de novembro de 1939. Cria o Parque Nacional da Serra dos Órgãos. Rio de Janeiro: 1939.

207 Nuances do Relevo

${ }^{208}$ BARROS, 1952, p. 16. Os decretos de $\mathrm{n}^{\circ} 90.023$ de 02 de agosto de 1984 , e o Decreto s/no de 15 de setembro de 2008, definiram novos limites e uma área de 20.024 hectares para o parque que, nesta nova delimitação incorporava parte do município de Guapimirim, localizado também no Rio de Janeiro. No artigo do Decreto $\mathrm{s} / \mathrm{n}^{\mathrm{o}}$ de 15 de setembro de 2008, foram definidos como objetivos do Parque: proteger amostras significativas da Mata Atlântica e sua biota associada, possibilitando a realização de pesquisas científicas; desenvolvimento de atividades de educação e interpretação ambiental, de recreação em contato com a natureza e de turismo ecológico (BRASIL. Decreto n. 90.023, de 2 de agosto de 1984. Define os limites do Parque Nacional da Serra dos Órgãos, criado pelo Decreto-lei n. 1.822 de 30 de novembro de 1939 e dá outras providências. Brasília: 1984; BRASIL. Decreto s/n. de 15 de setembro de 2008. Dá nova redação aos arts. $1^{\circ}, 2^{\circ}, 3^{\circ}$ e $4^{\circ}$ do Decreto n. 90.023 , de 2 de agosto de 1984 , que define os limites do Parque Nacional da Serra dos Órgãos, no Estado do Rio de Janeiro, e dá outras providências. Brasília: 2008).

${ }^{209}$ BRASIL. Decreto-lei n. 9.226, de 2 de maio de 1946. Cria a floresta nacional do Araripe-Apodi. Rio de Janeiro: 1946.

210 BRASIL. Ministério de Meio Ambiente. Áreas Protegidas. Disponível em <http://www.mma.gov.br/areas-protegidas/cadastro-nacional-de-ucs/consulta-gerar-relatorio-de-uc>. Acesso em: 16 jan. 2013.

Em 2012, através do Decreto de 5 junho, a área da Floresta Nacional do Araripe-Apodi foi ampliada para 38.919,00 hectares. Também enuncia como seus objetivos de criação: promoção do manejo de uso múltiplo sustentável os recursos florestais, conservação da fauna e da flora da região compreendida pelo 
Em 1948, foi a vez do Parque Nacional de Paulo Afonso, também no bioma da Caatinga, abrangendo áreas do município de Água Branca, no estado de Alagoas; do município de Petrolândia, em Pernambuco; e do município de Glória, na Bahia, perfazendo uma área total de $16.865,42$ hectares $^{211}$.

No artigo $3^{\circ}$ do Decreto de criação do Parque ficou estabelecido que, para fins de aproveitamento da energia hidráulica da cachoeira de Paulo Afonso, o Ministério da Agricultura ficava autorizado a ceder oportunamente à Companhia Hidroelétrica do São Francisco, pelo prazo que durasse a concessão desta, a parte da área do Parque que fosse julgada necessária ${ }^{212}$.

Observamos que o próprio decreto de criação do parque foi contraditório, ao permitir o funcionamento da Companhia Hidroelétrica do São Francisco. Pois, não atendia aos objetivos de criação de um parque que, pelo Decreto Legislativo de defesa da proteção e conservação das belezas cênicas naturais, proibia quaisquer intervenções que alterassem o ecossistema local.

De acordo com Barros, os objetivos de criação do parque assemelhavam-se aos outros já criados. A região era perfeita para a implantação de um parque, com paisagens exuberantes, ideal para o turismo. A presença de Cânions do São Francisco, a cachoeira de Paulo Afonso, a flora típica da caatinga, e os remanescentes animais do Nordeste ${ }^{213}$, contribuíam para uma diferenciada contemplação da natureza. Mas, todas estas características não foram suficientes para a manutenção do parque, que foi extinto em 13 de dezembro de 1968, para dar lugar à Companhia Hidro Elétrica do São Francisco ${ }^{214}$. Mais uma vez o projeto desenvolvimentista se mostrou superior às questões relacionadas à proteção ambiental.

Fechando o período de 1930 ao início dos anos 1950, vemos assim, que mesmo com a criação de quatro parques e uma floresta nacional, o Brasil protegeu apenas $2.624,01 \mathrm{~km}^{2}$, região irrisória quando comparada à sua enorme dimensão territorial, mais que 8.500.000,00 km², o maior país da América do Sul. Já a Argentina, por exemplo, país com superfície territorial bem menor $\left(2.780 .400,00 \mathrm{Km}^{2}\right)$, e com menos atributos

Complexo do Altiplano Sedimentar da Chapada do Araripe (BRASIL. Decreto de 5 de junho de 2012. Dispõe sobre a ampliação e os objetivos da Floresta Nacional do Araripe-Apodi, no Município de Barbalha, Estado do Ceará, criada pelo Decreto-lei n. 9.226, de 2 de maio de 1946. Brasília: 2012).

${ }^{211}$ BRASIL. Decreto n. 25.865, de 24 de novembro de 1948. Cria o Parque Nacional de Paulo Afonso. Rio São Francisco, entre Petrolina e Sobradinho: 1948.

212 Id.

213 BARROS, 1952, p. 12.

${ }^{214}$ BRASIL. Decreto-lei n. 605, de 2 de julho de 1969. Extingue o Parque Nacional de Paulo Afonso e dá outras providências. Brasília: 1969. 
para a criação de parques, conseguiu ser pioneira neste empreendimento. Criou seis grandes parques, o "Nahuel Huaipi Nacional Parque", de 1903, é um exemplo de grande área protegida, compreendendo uma faixa de terra de $784.682,00$ hectares $^{215}$, quase $8.000,00 \mathrm{~km}^{2}$.

Como vimos, no período do pós-guerra, com a criação de organismos internacionais, como a ONU, as campanhas de proteção ao meio ambiente e, em particular, o incentivo à criação de áreas protegidas, ganharam crescente destaque. No entanto, no Brasil, depois da criação dos primeiros parques e apesar da consolidação das reflexões a respeito dos conceitos conservacionistas, a exemplo do que ocorria em todo o mundo, a expansão do sistema nacional de parques foi lenta ${ }^{216}$.

Depois da criação do Parque Nacional de Paulo Afonso, onze anos se passaram sem a criação de parques ou reservas biológicas. Assim, apesar dos avanços na legislação ambiental brasileira, que evoluiu de acordo com os padrões internacionais de proteção a áreas protegidas, a destruição dos recursos florestais no país continuou crescendo.

Entre 1959 e 1961 iniciou-se uma nova etapa na criação de unidades de conservação. Nestes anos, ao todo, foram implantadas doze áreas, sendo onze Parques Nacionais e uma Floresta Nacional, abrangendo uma área total de 2.633.387,47 hectares, o equivalente a $26.333,87 \mathrm{~km}^{2}$. Do total dos parques criados cinco estavam concentrados no Bioma da Mata Atlântica, quatro no Cerrado e dois na Caatinga; e a Floresta Nacional localizada no Bioma Amazônico.

Pela literatura, apesar da grande maioria das unidades de conservação deste período, ainda se localizarem no bioma da Mata Atlântica, o surgimento de unidades no Centro-Oeste e a efetivação da primeira Floresta Nacional na Amazônia, estiveram associadas ao processo de transferência da capital nacional para o interior do país e à política de abertura de estradas ${ }^{217}$.

\footnotetext{
${ }^{215}$ BARROS, 1952, p. 21.

${ }^{216}$ QUINTÃO, 1983, p. 20; BATARCE, Ana Paula Archanjo. Evolução das Unidades de Conservação no Contexto Nacional. Anais... XVI ENG, Encontro Nacional de Geógrafos - crise, práxis e autonomia: espaços de resistências e de esperanças, p.1-10. Porto Alegre, 25 a 31 de julho de 2010, p. 2.

${ }^{217}$ CUNHA e COELHO, 2012, p.47.
} 


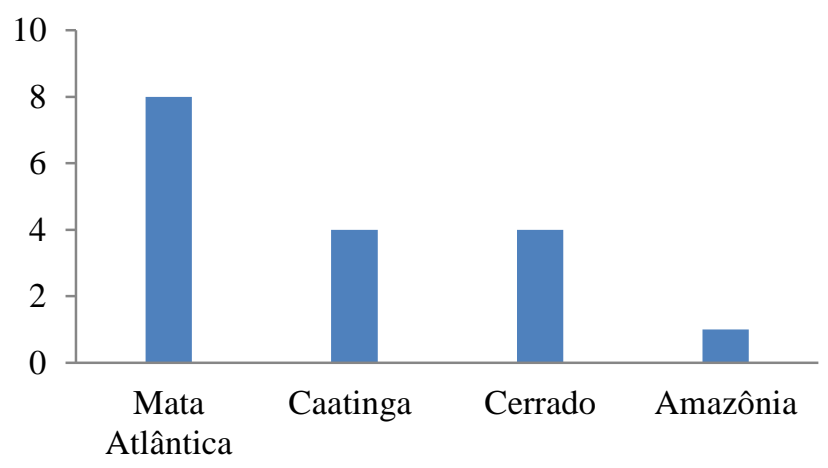

Gráfico 2 Unidades de Conservação criadas no período de 1937 a 1961 no Brasil. Fonte: Pesquisa da autora.

Em 1959 foram criados três Parques Nacionais, o de Aparados da Serra na Mata Atlântica, o de Ubajara na Caatinga e o de Araguaia no bioma do Cerrado, cobrindo juntos, uma área de 2.057.000,00 hectares, uma cifra alta quando comparada ao que se protegeu no primeiro período (1937-1948), que foi de apenas 262.401,92 hectares.

Note-se que, depois da criação do Parque de Araguaia, gerou-se um conflito de interesses, pois a presença indígena na região não foi considerada no ato da criação, ficando as áreas do parque sobrepostas à área indígena. O que levou técnicos conservacionistas e indigenistas a exigirem uma solução para o problema criado, já que na área do Parque era rigorosamente proibida a utilização dos recursos naturais, fato que inviabilizava a sobrevivência e desenvolvimento das populações indígenas naquele local $^{218}$.

O ano de 1961 foi marcado pela criação de nove áreas protegidas, sendo oito Parques Nacionais e uma Floresta Nacional. Desta vez, a extensão de áreas legalmente protegidas atingiu um total de $576.387,47$ hectares. Do total de parques criados quatro localizaram-se no bioma da Mata Atlântica, três no Cerrado e um na Caatinga, e a categoria de Floresta Nacional no bioma amazônico.

\footnotetext{
${ }^{218}$ MMA/IBAMA. Plano de Manejo do Parque Nacional do Araguaia-TO. Brasília-DF: Ministério do Meio Ambiente/Instituto Brasileiro do Meio Ambiente e dos Recursos Naturais Renováveis, 2001, p. 8. - O problema da sobreposição de áreas só foi resolvido em 1980, quando o parque foi dividido, criando-se uma área indígena, através de Decreto (BRASIL. Decreto n. 84.844, de 24 de junho de 1980. Altera os limites do Parque Nacional do Araguaia e do Parque Indígena do Araguaia. Brasília: 1980).
} 


\subsection{Evoluções das políticas públicas ambientais e das unidades de conservação no período de 1964 a 1985}

\subsubsection{Desenvolvimentismo e políticas públicas ambientais}

Castro Jr, Coutinho e Freitas, destacam que no período militar, " $a$ visão nacionalista de defesa do território através de práticas associadas a um desenvolvimento tecnocrata tornou-se preponderante, o que iria refletir na política de proteção da natureza" ${ }^{219}$.

Realmente, neste período, o caráter autoritário, centralizador e tecnocrático do regime reforçou e deu novas características às políticas desenvolvimentistas e de ocupação das regiões Oeste e Norte do país. Ao mesmo tempo, o crescimento dos movimentos ambientalistas e a ação dos organismos internacionais, que levaram a acordos como o implementado, em 1972, pela Conferência das Nações Unidas pelo Meio Ambiente, realizada pela UNESCO em Estocolmo, praticamente obrigaram o governo brasileiro a incorporar, em sua agenda, políticas de proteção ao meio ambiente.

Esta mudança de postura fica clara já nos dois Planos Nacionais de Desenvolvimento (PND's) implantados nos anos 1970.

Em 1971, foi aprovado, pela Lei n. 5.727 de 4 de dezembro, o I Plano Nacional de Desenvolvimento (PND), para o período 1972-1974, que defendia uma política de "desenvolvimento a qualquer preço". De acordo com o Plano, o governo estabelecia três grandes objetivos nacionais para o desenvolvimento brasileiro. Primeiro, colocar o Brasil, no espaço de uma geração, na categoria das nações desenvolvidas; duplicar até 1980, a renda per capita do Brasil (em comparação com 1969, devendo verificar-se, para isso, crescimento anual do Produto Interno Bruto equivalente ao dos últimos três anos); e, por último, elevar a economia, em 1974, às dimensões resultantes de um crescimento anual do Produto Interno Bruto entre 8 e $10 \%{ }^{220}$.

Em 1974 foi aprovado o II Plano Nacional de Desenvolvimento (1975-1979), através da Lei n. 6.151, de 4 de dezembro ${ }^{221}$, que previa investimentos "na indústria de base e energia, no contexto da crise energética então vivenciada, com destaque para a

\footnotetext{
${ }^{219}$ CASTRO Jr.; COUTINHO e FREITAS, 2009, p. 41.

${ }^{220}$ BRASIL. Lei n. 5.727, de 4 de novembro de 1971. Dispõe sobre o Primeiro Plano Nacional de Desenvolvimento (PND), para o período de 1972 a 1974. Brasília: 1971.

221 BRASIL. Lei n. 6.151, de 4 de dezembro de 1974. Dispõe sobre o Segundo Plano Nacional de Desenvolvimento (PND), para o período de 1975 a 1979. Brasília: 1974.
} 
produção de energia nuclear, pesquisa de petróleo, desenvolvimento de programa do álcool e construção de hidrelétricas, como Itaipu" 222. No entanto, o II PND já incorporava algumas propostas para a questão ambiental. Em seu Capítulo 9 defendia a ideia de um "desenvolvimento sem deterioração da qualidade de vida e sem devastação do patrimônio de recursos naturais do país". Especificamente para a Amazônia defendia que, paralelamente às atividades de agropecuária, deveriam ser tomados cuidados no uso das terras. Também citava a necessidade de escolha de áreas para a criação de novas Unidades de Conservação.

Nestes anos, uma das grandes preocupações do governo brasileiro foi a ocupação da região amazônica, vista como, até então, uma área inabitada. Com base nos PND's, vários organismos e programas foram criados para ocupação da região amazônica $^{223}$.

Os rios eram os únicos meios de penetração na região e a exploração madeireira era restrita às florestas de várzeas, em áreas acessíveis ao transporte por barco. A instalação das rodovias Belém-Brasília, Transamazônica e Cuiabá- Porto Velho possibilitaram a instalação dos grandes projetos agropecuários e a formação dos primeiros núcleos urbanos, as agrovilas. A partir daí iniciou-se um intenso processo de desmatamento ao longo das estradas, caminhando para o interior, resultando no final de 1988, na extração de mais de 25 milhões de hectares de florestas (as madeiras mais procuradas eram o Mogno, Andiroba, Angelim, Copaíba e, Pau-rosa) ${ }^{224}$.

A abertura de estradas, aliada ao declínio dos estoques de madeira comercial no Sul e Sudeste do país, possibilitou que a exploração florestal deixasse de ser uma atividade de menor importância para se tornar uma indústria de forte crescimento econômico, tanto pela retirada seletiva das árvores de maior valor como pela exploração mais intensiva de áreas convertidas ao uso agropecuário ${ }^{225}$. Tais políticas de ocupação, mesmo com as ressalvas contidas no II PND, deixaram rastros de destruição dos

\footnotetext{
${ }^{222}$ LEUZINGER, 2009, p. 98.

${ }^{223}$ Dentre eles podemos destacar a criação do Banco da Amazônia S/A (BASA), da Superintendência do Desenvolvimento da Amazônia (SUDAM), do Fundo para Investimentos Privados no Desenvolvimento da Amazônia (FIDAM), da Zona Franca de Manaus (ZFM), do Programa de Redistribuição de Terras e de Estímulo à Agroindústria do Norte e Nordeste (PROTERRA), do Programa de Incentivo à Produção da Borracha Vegetal (PROBOR) e, o Programa de Pólos Agropecuários e Agrominerais da Amazônia (POLAMAZÔNIA). Estes organismos e programas serão melhor detalhados no capítulo 3.

${ }^{224}$ LEÃO, Regina Machado (pesquisa e edição de texto). A Floresta e o Homem. São Paulo: Editora da Universidade de São Paulo: Instituto de Pesquisas e Estudos Florestais: 2000, p. 180.

${ }^{225}$ LEÃO, 2000, p. 182.
} 
recursos florestais, chamando a atenção internacional para o que estava acontecendo na Amazônia.

Assim, na esteira destes planos, o governo federal começou a implantar uma política nacional do meio ambiente, com a formação de um aparato jurídico e institucional caracterizado por um forte centralismo administrativo. Vejamos, a seguir, quais foram os principais marcos deste processo.

\section{- O Código Florestal de 1965}

No período dos governos militares, um dos primeiros acontecimentos relacionados às questões da preservação ambiental foi a aprovação, em 1965, do novo Código Florestal do Brasil ${ }^{226}$. Este código foi resultado de longo processo iniciado ainda nos anos de 1950 e estabelecia normas mais específicas de proteção para os recursos florestais em todo o país. Entre as novidades do novo código, que não constavam do primeiro Código Florestal (1934), estava o estabelecimento de critérios de utilização em áreas consideradas como pequena propriedade ou de posse rural familiar (aquelas que obtinham renda bruta de no mínimo $80 \%$ proveniente de atividade agroflorestal ou do extrativismo) ${ }^{227}$. O Código indicava ainda que um órgão específico do Ministério da Agricultura seria responsável pela sua aplicação.

Também ficou definida a obrigatoriedade da preservação de uma parte das propriedades, denominada Reserva Legal, considerada pelo Código necessária ao uso sustentável dos recursos naturais, à conservação e reabilitação dos processos ecológicos, à conservação da biodiversidade e ao abrigo e proteção de fauna e flora nativas ${ }^{228}$.

Outra novidade importante foi a definição da proteção das Áreas de Preservação Permanente (APP's), estando elas cobertas ou não por vegetação nativa,

\footnotetext{
${ }^{226}$ BRASIL. Lei N..$^{\mathbf{0}}$ 4.771, de 15 de setembro de 1965. Institui o novo Código Florestal. Brasília: 1965. O Código Florestal de 1965 vigorou até a publicação da Lei n. 12.651, de 25 de maio de 2012, que instituiu novas regras para a proteção da vegetação nativa.

${ }^{227}$ Os tamanhos das propriedades rurais variavam de acordo com aa regiões do país. Nos Estados do Acre, Pará, Amazonas, Roraima, Rondônia, Amapá, Mato Grosso, parte das áreas situadas ao norte dos Estados de Tocantins e Goiás, parte oeste do Maranhão ou no Pantanal mato-grossense ou sul-mato-grossense, considerou-se como pequena propriedade a área que tivesse 150,00 hectares; para a região localizada no polígono das secas ou ainda parte leste do Estado Maranhão, considerou-se 50,00 hectares; e, para as demais regiões do país ficou estabelecido que a abrangência de uma pequena propriedade rural seria de 30,00 hectares.

${ }^{228}$ O tamanho da Reserva Legal também ficou estabelecido de acordo com a localização no país: $80 \%$ para as propriedades rurais situadas em área de floresta da Amazônia Legal; 35\% nas propriedades de cerrado localizada dentro da Amazônia Legal; 20\% em propriedades que se localizassem em área de floresta ou outras formas de vegetação nativa, situadas nas demais regiões do país.
} 
tendo em vista sua função ambiental ${ }^{229}$. A proteção das APP's baseou-se na preservação dos recursos hídricos, da paisagem, da estabilidade geológica, da biodiversidade, do fluxo gênico de fauna e flora, da proteção do solo e da garantia do bem estar das populações humanas ${ }^{230}$.

Quanto aos Parques (Nacionais, Estaduais e Municipais) e Reservas Biológicas, o Poder Público passou a ser responsável pela sua criação. O Código ressaltava como sua finalidade resguardar atributos excepcionais da natureza, conciliando a proteção integral da flora, da fauna, e das belezas naturais com a utilização para objetivos educacionais, recreativos e científicos.

A criação das Florestas (Nacionais, Estaduais e Municipais), também ficaram sob responsabilidade do Poder Público, que tinha como objetivos fins econômicos, técnicos ou sociais.

Dois anos após a aprovação do novo Código Florestal, em 1967, foi criado o Instituto Brasileiro de Desenvolvimento Florestal (IBDF), entidade autárquica, ligada ao Ministério da Agricultura, com sede e foro no Distrito Federal e jurisdição em todo o Território Nacional. O foco principal do IBDF era o de formular a política florestal, orientar, coordenar e executar ou fazer executar as medidas necessárias à utilização racional, à proteção e à conservação dos recursos naturais renováveis e ao desenvolvimento florestal do país ${ }^{231}$.

De acordo com o artigo $4^{\circ}$ do Decreto-lei que criou o IBDF, competia prioritariamente ao novo órgão, traçar as diretrizes gerais da política florestal do País e elaborar planos anuais e plurianuais; levantar e fazer inventário dos recursos florestais; trabalhar com pesquisas e experimentações nos campos da silvicultura, da tecnologia das madeiras e da fauna silvestre; realizar e promover o reflorestamento com fins econômicos e ecológicos; dentre outros ${ }^{232}$. Dentre as suas funções constava ainda a responsabilidade de administrar o Jardim Botânico do Rio de Janeiro, os Parques

\footnotetext{
${ }^{229}$ No Código consideraram-se Áreas de Preservação Permanente, as florestas e demais formas de vegetação natural, situadas ao longo dos rios ou de outro qualquer curso d'água; ao redor das lagoas, lagos ou reservatórios d'água naturais ou artificiais; nas nascentes, mesmo nos chamados "olhos d'água", para qualquer situação topográfica, no topo de morros, montes, montanhas e serras; nas encostas ou partes destas, com declividade superior a $45^{\circ}$, equivalente a $100 \%$ na linha de maior declive; nas restingas, como fixadoras de dunas ou estabilizadoras de mangues; nas bordas dos taboleiros ou chapadas, altitude superior a 1.800 (mil e oitocentos) metros, nos campos naturais ou artificiais, as florestas nativas e as vegetações campestres. Vale destacar que as florestas de domínio privado, não ficaram sujeitas ao regime de utilização limitada, ressalvadas apenas as áreas de preservação permanentes. ${ }^{230} \mathrm{Id}$.

231 BRASIL. Decreto-Lei $\mathbf{N}^{\mathbf{0}}$ 289, de 28 de fevereiro de 1967. Cria o Instituto Brasileiro do Desenvolvimento Florestal e dá outras providências. Brasília: 1967. ${ }^{232} \mathrm{Id}$.
} 
Nacionais, as Florestas Nacionais, as Reservas Biológicas e os Parques de Caça Federais $^{233}$.

\section{- Os Anos 1970}

Segundo a literatura, as polêmicas que se implantaram em torno da proposta brasileira de desenvolvimento a qualquer custo, e a realização da Conferência de Estocolmo (1972), influenciaram na criação, em 1973, da Secretaria Especial de Meio Ambiente (SEMA) ${ }^{234}$, ligada ao Ministério do Interior.

De acordo com o Decreto de criação da SEMA, ficava sob sua competência, acompanhar as transformações do ambiente com ajuda de técnicas de aferição direta e sensoriamento remoto; assessorar órgãos e entidades que estivessem relacionadas com a conservação do meio ambiente; elaborar normas e padrões relativos à preservação do meio ambiente (em especial dos recursos hídricos, para que assegurassem o bem-estar das populações e o seu desenvolvimento econômico e social); desenvolver atividades de fiscalização; formar e treinar técnicos e especialistas na área ambiental, dentre outras ${ }^{235}$.

Como vimos anteriormente, o instituto responsável pelas unidades de conservação era o IBDF, e com a criação da SEMA passaram a existir dois sistemas paralelos, que tinham basicamente a mesma função. À SEMA cabia a criação e administração de estações ecológicas, áreas de proteção ambiental, reservas ecológicas e áreas de relevante interesse ecológico. Enquanto que o IBDF ficou responsável pela criação e gestão de parques nacionais, reservas biológicas, florestas nacionais e parques de caça ${ }^{236}$.

Ainda em relação às políticas ambientais e relativas às áreas de preservação, a literatura considera que o ano de 1979 foi um marco no processo de implantação de áreas protegidas no Brasil. Neste ano, o presidente da República aprovou o Decreto $\mathrm{n}^{\circ}$

\footnotetext{
${ }^{233}$ Como veremos, o IBDF atuou até 1989, quando foi extinto. O Instituto conduziu os estudos de projetos do governo federal que tinham como objetivo definir um sistema nacional de proteção às unidades de conservação, o que de fato se consolidou no ano de 2000 com a publicação da Lei n. 9.985 que instituiu o Sistema Nacional de Unidades de Conservação da Natureza (SNUC).

${ }^{234}$ BRASIL. Decreto n. 73.030, de 30 de outubro de 1973. Cria, no âmbito do Ministério do Interior, a Secretaria Especial do Meio Ambiente - SEMA, e dá outras providências. Brasília: 1973.

${ }^{235} \mathrm{Id}$.

${ }^{236}$ LEUZINGER, 2009, p. 97- 98. Segundo Leuzinger, durante seu período de existência (1973 a 1989), a SEMA atuou basicamente no controle da poluição; na educação ambiental; na conservação de ecossistemas; e na prevenção de extinção de espécies. Entretanto para a autora, a ação da Secretaria sempre esteve cercada de controvérsia, pois o Ministério do Interior era um dos principais responsáveis pela implementação de estratégias de desenvolvimento acelerado, objetivos que iam de encontro às atribuições da SEMA.
} 
84.017, que instituiu o Regulamento dos Parques Nacionais. No Decreto, os objetivos dos parques no país eram definidos a partir dos conceitos estabelecidos pela $10^{\mathrm{a}}$ Assembléia Geral da UICN, realizado em Nova Delhi, em $1969^{237}$.

Os Parques foram definidos como "áreas geográficas extensas e delimitadas, dotadas de atributos naturais excepcionais, objeto de preservação permanente, submetidas à condição de inalienabilidade e indisponibilidade no seu todo"238. Também, pelo Decreto, os Parques tinham por principal objetivo a preservação dos ecossistemas naturais, sendo destinados para fins científicos e culturais (educação e recreação), cabendo às autoridades preservá-los e mantê-los intocáveis.

Ainda de acordo com o artigo $2^{\circ}$ do Decreto, para serem considerados Parques Nacionais as áreas teriam que atender no mínimo a três exigências. Primeiro, possuir um ou mais ecossistemas totalmente inalterados ou parcialmente alterados pela ação antrópica, onde a flora e a fauna, os sítios geomorfológicos e habitats, oferecessem interesse especial para a ciência, a cultura, a educação e a recreação; ou, onde existissem paisagens naturais de grande valor cênico. Em segundo lugar, que tivessem sido objeto, por parte da União, de medidas efetivas para impedir ou eliminar as causas das alterações ambientais e para proteger efetivamente os fatores biológicos, geomorfológicos ou cênicos, que determinavam a criação do parque. E, por último, que a visitação pública fosse condicionada, com restrições específicas.

Também ficou estabelecida neste Decreto a obrigatoriedade da elaboração do Plano de Manejo ${ }^{239}$ da unidade, objetivando a compatibilização da preservação dos ecossistemas protegidos, com a utilização dos benefícios deles advindos. Ainda ficava estabelecido que o plano, depois de elaborado, deveria sofrer revisão periódica a cada cinco anos.

A intenção do Plano de Manejo dos parques era indicar de forma detalhada o zoneamento de sua área total, podendo conter no todo ou em parte sete zonas diferenciadas em suas características: intangível, primitiva, de uso extensivo, de uso intensivo, histórico cultural, de recuperação, e de uso especial ${ }^{240}$.

\footnotetext{
${ }^{237}$ QUINTÃO, 1983, p. 20.

238 BRASIL. Decreto no 84.017, de 21 de setembro de 1979. Aprova o Regulamento dos Parques Nacionais Brasileiros. Brasília: 1979.

${ }^{239}$ De acordo com o Decreto n. 84.017 de 1979, que aprovou o regulamento dos Parques Nacionais, entende-se por Plano de Manejo o projeto dinâmico que, utilizando técnicas de planejamento ecológico, determina o zoneamento de um Parque Nacional, caracterizando cada uma das suas zonas e propondo seu desenvolvimento físico, de acordo com suas finalidades.

${ }^{240}$ As características das sete zonas estabelecidas pelo Decreto $\mathrm{n}^{\circ} 84.017$, que regulamentou os Parques Nacionais Brasileiros, podem ser observadas na Tabela 4 em anexo.
} 
Podemos concluir que o Decreto de regulamentação dos Parques trouxe dois pontos importantes: a obrigatoriedade da elaboração dos Planos de Manejo e a estrutura de zoneamento. Considerando a obrigatoriedade dos Planos de Manejo, observamos a importância dada ao planejamento, tanto quanto ao processo de criação e implantação das áreas protegidas. No entanto, não foram previstas, para os parques nacionais, zonas que permitissem a permanência de populações tradicionais residentes. O que revela a existência, no país, de uma tendência preservacionista, no que concerne aos espaços protegidos, que proibia a presença de grupos humanos em diferentes categorias de manejo $^{241}$. Note-se que, apesar da idéia de zoneamento só ter surgido no Brasil em 1979, por meio do Decreto que regulamentou os Parques Nacionais, em nível internacional ele foi incorporado como instrumento do planejamento de unidades de conservação, em 1972, durante a 11 a Assembléia Geral da UICN, realizada em Banff, Canadá ${ }^{242}$.

Achamos importante destacar ainda, os estudos realizados pelo governo federal, durante toda a década de 1970 (estendendo-se para década de 1980), através do PROJETO RADAMBRASIL, publicados em vários volumes. O Projeto realizou uma série de inventários quantitativos e qualitativos sobre as características bióticas e abióticas, com vistas a integração e padronização das informações dos recursos naturais. As publicações dos volumes até hoje servem como base para estudos em diversas áreas. Quando da escolha das áreas a serem transformadas em unidades de conservação no Brasil, o RADAMBRASIL, constitui-se na primeira fonte, que indicou em suas publicações áreas com grande biodiversidade, ideais para serem protegidas através da implantação de unidades de conservação.

\section{- A década de 1980}

A década de 1980 foi importante para a consolidação das normas legais visando uma proteção mais abrangente do ambiente natural brasileiro. Em 1981, foi aprovada a Lei $\mathrm{n}^{\circ}$ 6.938, que instituiu a Política Nacional do Meio Ambiente (PNMA), tendo como objetivo a preservação, melhoria e recuperação da qualidade ambiental propícia à vida, visando "assegurar condições ao desenvolvimento socioeconômico, aos

${ }^{241}$ LEUZINGER, 2009, p. 99.

${ }^{242}$ BRITO, 2003, p. 62. 
interesses da segurança nacional e à proteção da dignidade da vida humana"243. Segundo a Política Nacional do Meio Ambiente, a criação das Unidades de Conservação (UC's) continuava a cargo do poder público. Foi então incluída a categoria das Reservas Extrativistas $^{244}$.

Com a criação da Política Nacional do Meio Ambiente, foi instituído o Sistema Nacional do Meio Ambiente (SISNAMA), composto pelos órgãos e entidades da União, dos Estados, do Distrito Federal, dos Territórios, dos Municípios e fundações instituídas pelo Poder Público, responsáveis pela proteção e melhoria da qualidade ambiental. Foi criado, também como Órgão Superior do sistema, o Conselho Nacional de Meio Ambiente (CONAMA) ${ }^{245}$.

Segundo Castro Jr, Coutinho e Freitas o CONAMA foi o último instrumento relevante da política ambiental brasileira criado pelo regime militar e continuou atuando no período democrático, o órgão máximo do SISNAMA e condutor da PNMA, exercendo papel fundamental na discussão das políticas públicas afins ${ }^{246}$.

Também em 1981, foi editada a Lei no 6.902, que regulamentou a criação de dois tipos de áreas protegidas, as Estações Ecológicas/ ESEC (áreas de uso indireto) e as Áreas de Proteção Ambiental/APAs (áreas de uso direto), categorias que permanecem em uso até os dias de hoje. As Estações Ecológicas foram definidas como áreas representativas de ecossistemas brasileiros, destinadas à realização de pesquisas básicas e aplicadas de Ecologia, à proteção do ambiente natural e ao desenvolvimento da educação conservacionista ${ }^{247}$. Nas Áreas de Proteção Ambiental foi estabelecida a possibilidade da propriedade das terras continuar a ser de particulares, com regulação e controle das atividades econômicas desenvolvidas em seu interior ${ }^{248}$.

\footnotetext{
${ }^{243}$ BRASIL. Lei n. 6.938, de 32 de agosto de 1981. Dispõe sobre a Política Nacional do Meio Ambiente, seus fins e mecanismos de formulação e aplicação, e dá outras providências. Brasília: 1981.

${ }^{244}$ BRASIL. Lei n. 7.804, de 18 de julho de 1989. Altera a Lei $\mathrm{n}^{\circ}$ 6.938, de 31 de agosto de 1981, que dispõe sobre a Política Nacional do Meio Ambiente, seus fins e mecanismos de formulação e aplicação, a Lei $\mathrm{n}^{\circ} 7.735$, de 22 de fevereiro de 1989, a Lei $\mathrm{n}^{\circ}$ 6.803, de 2 de julho de 1980, e dá outras providências. Brasília: 1989.

${ }^{245}$ BRASIL. Decreto n. 88.351, de $1^{\circ}$ de junho de 1983. Regulamenta a Lei $n^{\circ} 6.938$, de 31 de agosto de 1981, e a Lei $\mathrm{n}^{\circ}$ 6.902, de 27 de abril de 1981, que dispõem, respectivamente, sobre a Política Nacional do Meio Ambiente e sobre a criação de Estações Ecológicas e Áreas de Proteção Ambiental, e dá outras providências. Brasília: 1983. O CONAMA era coordenado pelo Ministro do Interior e formado por conselheiros e representantes de vários setores da sociedade.

${ }^{246}$ CASTRO Jr.; COUTINHO e FREITAS, 2009. p. 42-43.

${ }^{247}$ BRASIL. Lei n. 6.902, de 27 de abril de 1981. Dispõe sobre a criação de estações ecológicas, áreas de proteção ambiental e dá outras providências Brasília: 1981.

${ }^{248}$ VIANNA, 2008, p.173. As Reservas da Biosfera foram sugeridas pela UNESCO em 1971, quando criou o Programa Homem e Biosfera. A ideia era estreitar a relação homem natureza, combatendo os efeitos dos processos de degradação e promovendo a conservação da natureza e o desenvolvimento sustentável (BRITO, 2003, p.59-60.)
} 
Segundo Vianna, a criação das APA's no Brasil acompanhou a proposta em escala mundial da criação das reservas da biosfera. Assim, só depois de quatro décadas desde a criação da primeira área legalmente protegida (o Parque Nacional de Itatiaia, em 1937), surgia, então, a primeira unidade de conservação que permitia, além do manejo e do uso direto dos recursos, a possibilidade da presença humana em seu interior ${ }^{249}$.

\subsubsection{A proposta de criação do Plano do Sistema de Unidades de Conservação do Brasil (PSUC): 1975 - 1982}

Com base no recomendado pelo II PND, o IBDF deu início ao projeto intitulado "Uma Análise de Prioridade para a Conservação da Natureza na Amazônia”, em 1975, que tinha por objetivo a definição de um programa geral para a conservação da natureza na região, incluindo a identificação, em bases científicas, de áreas chaves a serem estudadas para sua futura proteção. O relatório, produto final do projeto foi publicado em $1976^{250}$.

Baseado nos estudos do IBDF surgiu, em 1979, o primeiro Plano do Sistema de Unidades de Conservação do Brasil (PSUC) ${ }^{251}$, que tinha como objetivo realizar um estudo detalhado das regiões apontadas como prioritárias no relatório de 1976; analisar as dez categorias de manejo propostas pela UICN, em 1978 ${ }^{252}$; além da realização de uma revisão das categorias de manejo existentes no Brasil.

O primeiro PSUC deveria se constituir em uma estratégia básica para a conservação e manejo dos recursos naturais renováveis e para a utilização adequada dos escassos recursos humanos e financeiros necessários à implantação, administração, manutenção e manejo de um Sistema de Unidades de Conservação.

Para tanto, o documento propôs cinco linhas de atuação: 1) escolher as áreas a serem protegidas e inventariar, a nível nacional (e particularizando, na Amazônia), as áreas de potencial interesse, como unidades de conservação; 2) identificar as lacunas e as áreas protegidas de maior importância no Sistema de Parques existente; 3) estabelecer critérios técnico-científicos da significância das áreas a incluir no Sistema; 4) rever a conceituação geral, no que toca aos objetivos de manejo e categorias de

\footnotetext{
${ }^{249}$ VIANNA, 2008, p.173.

${ }^{250}$ QUINTÃO, 1983, p. 22. No capítulo 4, será analisada a importância deste relatório para a indicação da área da Serra do Divisor no Acre, como adequada à criação de uma UC.

${ }^{251}$ PÁDUA, Maria Tereza Jorge e PORTO, Eduardo Lourenço Rocha (coord.). Plano do Sistema de Unidades de Conservação do Brasil. Brasília: IBDF, FBCN, 1979. 108p.

${ }^{252}$ BRITO, 2003, p. 61.
} 
manejo; e 5) propor áreas prioritárias para o estabelecimento, planificação, manejo e administração desse Sistema ${ }^{253}$.

A ideia de um Plano com tais objetivos era impulsionar a criação de um Sistema de Unidades de Conservação que cobrisse uma grande variedade de ecossistemas existentes e garantisse a proteção e conservação dos recursos naturais renováveis, especialmente a flora e fauna ${ }^{254}$.

O documento ainda propunha vários objetivos de manejo para compor o sistema de unidades de conservação do país. E, a partir desses objetivos, determinava cinco categorias de manejo de unidades de conservação para o Brasil: Importância Nacional, Complementares, Adicionais, Regionais ou Locais e, Importância Mundial (maiores detalhes ver Tabela 5 e 6 em anexo).

O trabalho realizado por K. Miller, N. Nunro e K. Thelen da Comissão de Parques Nacionais e Áreas Protegidas da UICN (Objectivies, Criterias and Categories for Conservation Areas, ainda não publicado na época); e a publicação de K. Miller e K. Thelen (Planificación de Sistema de Areas Silvestres, de 1976), serviram de base para a formulação da proposta brasileira do I PSUC ${ }^{255}$.

O I PSUC apontou a existência no Brasil, até 1979, de cinquenta e nove unidades de conservação, sendo nove já existentes e cinquenta planejadas, para a Amazônia brasileira. Dentre as planejadas destacamos a indicação da Reserva Biológica Cruzeiro do Sul, constituindo-se na única área apontado para o Estado do Acre 256 Ressaltamos que a maioria das áreas estudadas neste período pelo IBDF foi recomendada pelo Projeto RADAMBRASIL, nas décadas de 1970 e 1980, como áreas potenciais para a criação de unidades de conservação ${ }^{257}$.

Além dos estudos de gabinete, foram realizadas cinco expedições na região norte do país, sendo estudadas trinta e quatro áreas para a implantação de novas unidades de conservação. Foi necessário o apoio de outras instituições como o Instituto Nacional de Pesquisas da Amazônia - INPA, Museu Goeldi, Projeto RADAMBRASIL, Universidade de Campinas, Universidade Federal do Piauí, Museu Nacional, Fundação Brasileira para a Conservação da Natureza - FBCN, Superintendência do

\footnotetext{
${ }^{253}$ PÁDUA e PORTO, 1979, p. 6; LEUZINGER, 2009, p. 103.

${ }^{254}$ PÁDUA e PORTO, 1979, p. 6

255 Id., p. $10-11$.

${ }^{256}$ Em 1989 foi criada nesta região o Parque Nacional da Serra do Divisor.

257 Wetterberg, G. B.; et. al. Uma Análise de Prioridades em Conservação da Natureza na Amazônia. Brasília: IBDF, PNUD, FAO, 1976. 62p. (Projeto de Desenvolvimento Florestal e Pesquisa Florestal, Série Técnica $N^{\circ}$ 8), p. 13.
} 
Desenvolvimento do Centro Oeste, e organismos internacionais como a WWF, UICN, e New York Zoological Society.

Para Brito, entre outras coisas, I PSUC defendia a necessidade do uso de critérios técnico-científicos na criação de Unidades de Conservação e na definição de suas categorias $^{258}$, além de atender as diretrizes estabelecidas pelo II PND, que defendia a criação de novas áreas protegidas na Amazônia ${ }^{259}$.

Em 1982 foi elaborada a II Etapa do Plano do Sistema de Unidades de Conservação para o Brasil que buscou, além da definição de critérios técnicos científicos para a indicação e implantação de unidades de conservação, a criação de novas categorias de manejo. Nesta fase, o Plano considerou os objetivos de conservação da natureza destacados por Pádua, em $1978^{260}$, tendo como base os trabalhos de K.D. Thellen e K.R. Miller, de 1976 (ambos da Agência Regional da FAO para a América Latina), além dos trabalhos da UICN (Planificación de sistemas de areas silvestres $e$ Objectives, criterias and categories for conservation areas $)^{261}$.

De acordo com Brito, a proposição de uma segunda etapa do Plano foi motivada: pela falta de categorias de manejo que atingissem os objetivos nacionais de conservação da natureza; pelo grande número de terminologias utilizadas para as unidades de conservação, que não eram consensuais quanto à sua definição; pela sobreposição de unidades de conservação de fins diversos; e, ainda, pela confusão de atribuições no âmbito dos poderes executivos (federais, estaduais e municipais) ${ }^{262}$.

Entretanto, apesar dos amplos estudos empreendidos pelos dois Planos, ainda não foi neste momento que se implantou o Sistema de Unidades de Conservação no país. Uma nova proposta de revisão foi reivindicada, e, em 1989, uma nova versão foi concebida.

\footnotetext{
258 Os Parques Nacionais brasileiros, como aconteceu em toda América Latia até a década de 1960, foram criados basicamente pela beleza cênica que encerram, e não pela necessidade de proteção de ecossistemas. Muitas delas representando uma situação estática, sem benefício social, cultural ou científico (PÁDUA e PORTO, 1979, p. 7).

${ }^{259}$ BRITO, 2003, p. 61.

${ }^{260}$ Proteger amostras de toda diversidade de ecossistemas do país; proteger espécies raras, em perigo ou ameaçadas de extinção, biótopos, comunidades bióticas únicas, formações geológicas e geomorfológicas de relevante valor, paisagens de rara beleza cênica; preservar o patrimônio genético; proteger a produção hídrica minimizando a erosão, a sedimentação; proteger os recursos da flora e fauna; conservar paisagens de relevantes belezas cênicas naturais ou alteradas mantidas a um nível sustentável; conservar valores culturais, históricos e arqueológicos; preservar grandes áreas provisoriamente até que estudos futuros indiquem sua melhor utilização; levar o desenvolvimento, através da conservação, a regiões até então pouco desenvolvidas; propiciar condições de monitoramento ambiental; proporcionar meios para educação, estudos, investigação e divulgação sobre os recursos naturais; e fomentar o uso racional dos recursos naturais, por meio de áreas de uso múltiplo (PÁDUA, 1978 apud BRITO, 2003, p. 64).

${ }^{261}$ BRITO, 2003, p.64-65.

262 Id., p.65.
} 
Finalizando este item, vemos assim que dos anos 1970 aos 1980, já havia um aparato jurídico, institucional e político relacionado à questão ambiental no Brasil. No entanto, a literatura, em geral, afirma que foi só a partir da segunda metade da década de 1980 que a política ambiental e a criação de unidades de conservação ganharam força no país.

Vejamos agora como foi a implantação de Unidades de Conservação no período dos governos militares.

\subsubsection{Unidades de Conservação criadas no período de 1968 a 1985}

No período de 1968 a 1985, foram implantadas setenta e sete unidades de conservação, em vários biomas do país, cobrindo uma área de 14.901.821,42 hectares, correspondendo a 149.018,21 $\mathrm{Km}^{2}$. A maioria das áreas protegidas concentraram-se no bioma Amazônico (29,87\%) e na Mata Atlântica (29,87\%). Porém quando levamos em consideração o tamanho das unidades, a região amazônica sozinha protegeu 11.681.192,37 hectares $\left(116.811,92 \mathrm{Km}^{2}\right)^{263}$. Esses números significam que, do total de áreas protegidas no período analisado, 78,4\% estavam em território amazônico, um valor substancial.

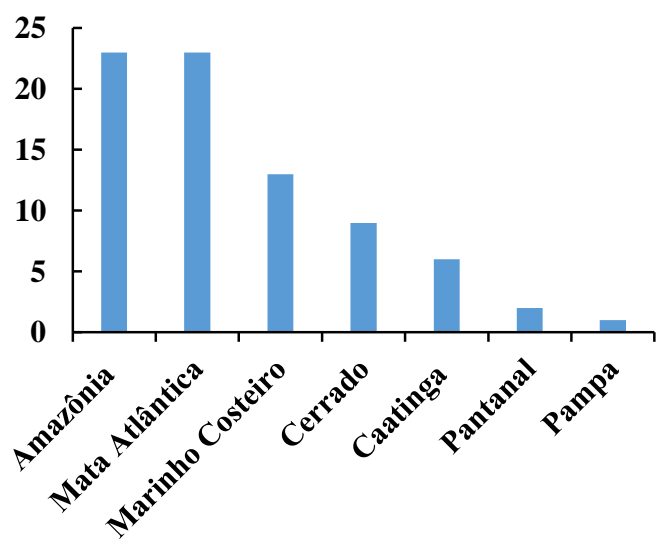

Gráfico 3 Unidades de Conservação no Brasil por Bioma, no período de 1968 a 1985.

Fonte: Pesquisa da autora.

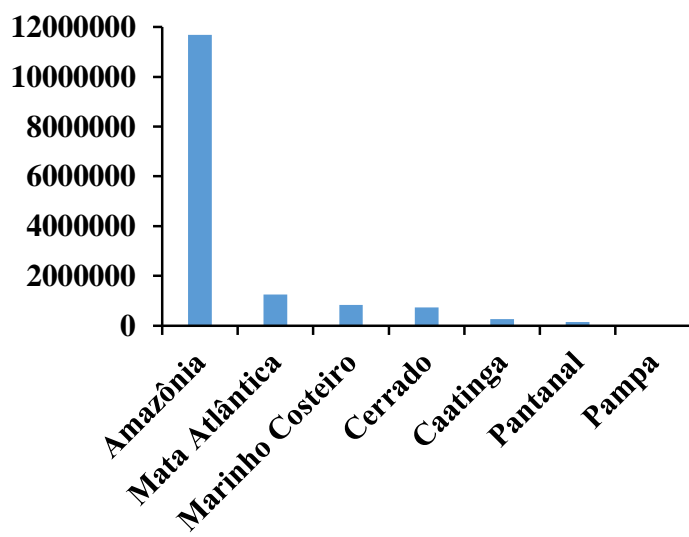

Gráfico 4 Unidades de Conservação no Brasil por tamanho (ha) e Bioma, no período de 1968 a 1985. Fonte: Pesquisa da autora.

\footnotetext{
263 Todas as características das Unidades de Conservação deste período estão resumidas na Tabela 7, em
} anexo. 
Em 1968, foram criadas dez áreas protegidas, situadas no bioma da Mata Atlântica, todas na categoria de manejo Floresta Nacional ${ }^{264}$, abrangendo uma área de 19.127,00 hectares, correspondendo a 191,27 km².

Entre 1971 e 1974, foram criadas mais cinco áreas protegidas, que abrangeram três categorias de manejo, Parque Nacional, Floresta Nacional e Reserva Biológica, protegendo 1.903.000,00 hectares $\left(19.030,00 \mathrm{~km}^{2}\right)$. Só na região amazônica as duas unidades criadas cobriram $16.000,00 \mathrm{~km}^{2}$.

E, entre 1979 e 1985, surgiram mais 62 unidades, resguardando uma área de 12.979.694,42 hectares $\left(129.796,94 \mathrm{Km}^{2}\right)$, período mais expressivo até então.

Como vimos no capítulo 1, o período dos anos 1960 aos 1980 foi marcado por uma série de eventos e programas internacionais em defesa dos recursos naturais. Como a Conferência da Biosfera (1968) e a criação, pela UNESCO, do Programa Homem e Biosfera (1971); a Conferência das Nações Unidas sobre o Ambiente Humano, em Estocolmo (1972); e a criação do Programa das Nações Unidas par o Meio Ambiente PNUMA (1972). Além disso, a União Internacional para a Conservação da Natureza UICN teve forte atuação, através da sua Comissão Parques, que realizou dois Congressos Mundiais de Parques Nacionais neste período (1972 e 1982).

Tudo isso repercutiu nos vários países. E o Brasil não ficou de fora.

Como vimos, foi criada a Secretaria Especial do Meio Ambiente (SEMA), em 1973; foi editado o Regulamento dos Parques Nacionais (1979); implantou-se a Política Nacional do Meio Ambiente (1981), o Sistema Nacional do Meio Ambiente (SISNAMA) e o Conselho Nacional do Meio Ambiente (CONAMA). Também, foi regulamentada a criação das Estações Ecológicas (ESEC's) e das Áreas de Proteção Ambiental (APA's), em 1981. Por fim, deu-se início aos estudos para a proposta de criação de um Sistema Nacional de Unidades de Conservação (1975 a 1982).

Consideramos que o aumento do número de unidades de conservação na região amazônica neste período foi possível pelo contexto internacional favorável, somado às políticas de ocupação para região que trouxeram grande devastação dos

\footnotetext{
${ }^{264}$ Anteriormente, todas as Florestas Nacionais criadas neste ano, eram denominadas de Parques Florestais e faziam parte do Instituto Nacional do Pinho, instituição criada em 1941 para atender os interesses dos produtores, industriais e exportadores de pinho. Este órgão teve sua raiz no Estado Novo, principalmente na "Marcha Para o Oeste", sendo criado como meio de buscar a legalização da madeira que seria exportada para os mercados europeus. Em 1967, o instituto foi extinto, e suas reservas passaram para o IBDF (GOLO, Cristiomar. Ilegalidade de Exploração Madeireira: ação do Instituto Nacional do Pinho no Oeste Catarinense:1941-1966. Revista Tempos Acadêmicos, Universidade Federal de Santa Catarina, v. 1, n. 6, 2008. Não paginado).
} 
recursos naturais da região. Que colocaram o país no foco dos movimentos ambientalistas internacionais e nacionais.

\subsection{Políticas públicas ambientais e evolução das unidades de conservação no período de 1985 a 2000}

\subsubsection{Evolução das Políticas Públicas Ambientais}

As mudanças que ocorreram no Brasil após 1985, com destaque para a reorganização dos espaços políticos, a expansão dos movimentos sociais e a aprovação da nova Constituição, em 1988, tiveram forte repercussão nas políticas ambientais do período. Também, logo no início dos anos 1990, aconteceu na cidade do Rio de Janeiro, a Rio-92, Conferência das Nações Unidas sobre Meio Ambiente e Desenvolvimento, considerada, pela literatura, um marco na história da política ambiental brasileira, pois o tema do meio ambiente ganhou repercussão na mídia e ficou mais próximo do cidadão comum e dos governantes brasileiros ${ }^{265}$.

Já nos primeiros anos, as mudanças na máquina administrativa federal levaram à realocação dos principais organismos responsáveis pela política ambiental. Assim, em 1985, no primeiro ano de governo de José Sarney, através do Decreto n. 91.145, de 15 de março, foi criado o Ministério do Desenvolvimento Urbano e Meio Ambiente, cabendo ao mesmo a direção da política habitacional, de saneamento básico, de desenvolvimento urbano, e do meio ambiente ${ }^{266}$. A partir da publicação deste Decreto, a Secretaria do Meio Ambiente (SEMA) que, desde 1973, estava sob o âmbito do Ministério do Interior foi transferida para este novo Ministério.

Durante o governo de Fernando Collor de Mello, o Ministério do Desenvolvimento Urbano e Meio Ambiente foi transformado na Secretaria do Meio Ambiente, estando diretamente vinculada à Presidência da República. E, logo depois a situação foi revertida pelo governo de Itamar Franco quando, no ano de 1993, criou o Ministério do Meio Ambiente e da Amazônia Legal.

As mudanças no tocante ao nome do Ministério não pararam por aí. Em 1995 passou a denominar-se Ministério do Meio Ambiente, dos Recursos Hídricos e da

\footnotetext{
265 VIANNA, 2008, p. 179.

${ }^{266}$ BRASIL. Decreto n. 91.145, de 15 de março de 1985. Cria o Ministério do Desenvolvimento Urbano e Meio Ambiente, dispõe sobre sua estrutura, transferindo-lhe os órgãos que menciona, e dá outras as
} 
Amazônia Legal e, posteriormente adotou o nome de Ministério do Desenvolvimento Urbano e do Meio Ambiente. Finalmente em 1999, no governo de Fernando Henrique Cardoso, passou a denominar-se Ministério do Meio Ambiente (MMA), permanecendo assim até os dias atuais.

Além destas mudanças, podemos dizer que a Constituição Federal, de 1988, consolidou de forma determinante a política ambiental no país. Pois, pela primeira vez em sua história constitucional, o Brasil dedicou um capítulo à questão do meio ambiente ${ }^{267}$.

As instruções sobre o meio ambiente ficaram dispostas nos diversos parágrafos e incisos do artigo 225 do capítulo VI da Constituição. O art. 225 estabelecia que "todos têm direito ao meio ambiente ecologicamente equilibrado, bem de uso comum do povo e essencial à sadia qualidade de vida, impondo-se ao Poder Público e à coletividade o dever de defendê-lo e preservá-lo para as presentes e futuras gerações "268.

De acordo com a Constituição, para assegurar a efetividade do direito estabelecido no artigo 225, o Poder Público foi incumbido de preservar e restaurar os processos ecológicos essenciais e prover o manejo ecológico das espécies e ecossistemas; preservar também a diversidade e a integridade do patrimônio genético do País e fiscalizar as entidades dedicadas à pesquisa e manipulação de material genético; definir em todas as unidades da Federação espaços territoriais e seus componentes a serem especialmente protegidos; exigir estudo prévio de impacto ambiental, na forma da lei, para instalação de obra ou atividade potencialmente causadora de significativa degradação do meio ambiente; controlar a produção, a comercialização e o emprego de técnicas, métodos e substâncias que comportem risco para a vida, a qualidade de vida e o meio ambiente; promover a educação ambiental em todos os níveis de ensino e a conscientização pública para a preservação do meio ambiente e; proteger a fauna e a flora, vedadas, na forma da lei, as práticas que coloquem em risco sua função ecológica, provoquem a extinção de espécies ou submetam os animais a crueldade ${ }^{269}$.

Vale destacar ainda o inciso $4^{\circ}$ do artigo 225 que definiu como patrimônio nacional as regiões da Floresta Amazônica, da Mata Atlântica, da Serra do Mar, do Pantanal Mato-Grossense e da Zona Costeira. Ficando estabelecido que a utilização

\footnotetext{
${ }^{267}$ Segundo Castro Jr; Coutinho e Freitas (2009, p.43), a Constituição de 1988 veio fortalecer a PNMA, o SISNAMA e o CONAMA. Depois da Constituição as áreas de proteção integral multiplicaram-se.

${ }^{268}$ BRASIL. Constituiçãa (1988). Constituição da República Federativa do Brasil. Brasília, DF: Senado Federal, 1988.

${ }^{269} \mathrm{Id}$.
} 
dessas regiões far-se-ia na forma da lei, dentro de condições que assegurassem a preservação do meio ambiente, inclusive quanto ao uso dos recursos naturais ${ }^{270}$.

$\mathrm{Na}$ esteira da Constituição ocorreram mudanças profundas nos organismos governamentais responsáveis pelas unidades de conservação até então criadas. Em 1989, foram extintos o Instituto Brasileiro de Desenvolvimento Florestal (IBDF) e a Secretaria Especial de Meio Ambiente (SEMA), instituições responsáveis pelas unidades de conservação até então criadas.

Todas as responsabilidades do IBDF e da SEMA passaram para um novo órgão, o Instituto Brasileiro de Meio Ambiente e dos Recursos Naturais Renováveis (IBAMA), criado em 1989, como uma autarquia federal dotada de personalidade jurídica de direito público, com autonomia administrativa e financeira, estando vinculada à Secretaria do Meio Ambiente da Presidência da República ${ }^{271}$. Além de assessorar na política nacional do meio ambiente, o IBAMA tornou-se gestor de todas as unidades de conservação federais do país, conduzindo a formulação da política de implantação dessas áreas em todos os níveis. Inclusive balizando e estimulando os órgãos estaduais e municipais de meio ambiente a implantar áreas protegidas ${ }^{272}$. A criação do IBAMA possibilitou, assim, a centralização na execução da Plano Nacional do Meio Ambiente (PNMA, de 1981).

De forma complementar, ainda em 1989, foi instituído o Fundo Nacional do Meio Ambiente (FNMA), administrado pela Secretaria do Meio Ambiente da Presidência da República, cujo principal objetivo era "desenvolver os projetos que visem ao uso racional e sustentável de recursos naturais, incluindo a manutenção, melhoria ou recuperação da qualidade ambiental no sentido de elevar a qualidade de vida da população brasileira"273. De acordo com o artigo $5^{\circ}$ da Lei que criou o FNMA, foram consideradas prioritárias as aplicações de recursos financeiros em projetos relativos a unidades de conservação, pesquisa e desenvolvimento tecnológico; educação ambiental; manejo e extensão florestal, desenvolvimento institucional, controle

\footnotetext{
${ }^{270}$ Ibid.

${ }^{271}$ BRASIL. Lei n. 7.745, de 22 de fevereiro de 1989. Dispõe sobre a extinção de órgão e de entidade autárquica, cria o Instituto Brasileiro do Meio Ambiente e dos Recursos Naturais Renováveis e dá outras providências. Brasília: Senado Federal, 1989.

${ }^{272}$ CASTRO Jr.; COUTINHO e FREITAS, 2009. p. 44.

${ }^{273}$ BRASIL. Lei n. 7.797, de 10 de julho de 1989. Cria o Fundo Nacional de Meio Ambiente e dá outras providências. Brasília: 1989.
} 
ambiental, e aproveitamento econômico racional e sustentável da flora e fauna nativas $^{274}$.

Quanto às ações empreendidas pelo governo brasileiro, além da continuidade na implantação de áreas de preservação, outras medidas merecem destaque pelo impacto que tiveram.

Com a publicação da Resolução Conama n⿳0 1, em 1986, foi estabelecido que o licenciamento de atividades modificadoras do meio ambiente passaria a depender da elaboração de Estudos de Impacto Ambiental e de seus respectivos Relatórios (EIAS/RIMA), que deveriam ser submetidos à aprovação do "órgão estadual competente e, em caráter supletivo, do órgão ambiental federal" 275 .

A Resolução considerava como impacto ambiental "qualquer alteração das propriedades físicas, químicas e biológicas do meio ambiente, causada por qualquer forma de matéria ou energia resultante das atividades humanas que, direta ou indiretamente", afetassem a saúde, a segurança e o bem-estar da população; as atividades sociais e econômicas; a biota; as condições estéticas e sanitárias do meio ambiente; e a qualidade dos recursos ambientais ${ }^{276}$.

Outras medidas aprofundaram os debates sobre os vários tipos de Unidades de Conservação a serem implantados no país, levando a uma ampliação destes tipos. Como a Resolução Conama no $\mathbf{n}^{\mathbf{1 1}}$, de 1987, que tratou de suas várias categorias e dos sítios ecológicos de relevância cultural. No artigo $1^{\text {o }}$ foram definidas como Unidades de Conservação as seguintes categorias de Sítios Ecológicos de Relevância Cultural: Estações Ecológicas; Reservas Ecológicas; Áreas de Proteção Ambiental, especialmente suas zonas de vida silvestre e os Corredores Ecológicos; Parques Nacionais, Estaduais e Municipais; Reservas Biológicas; Florestas Nacionais, Estaduais e Municipais; Monumentos Naturais; Jardins Botânicos; Jardins Zoológicos; e Hortos Florestais ${ }^{277}$.

Ou a criação, em 1990, de mais um tipo de Unidade de Conservação, as Reservas Extrativistas (RESEX) ${ }^{278}$ que foram definidas como: “espaços territoriais destinados à exploração auto-sustentável e à conservação dos recursos naturais

\footnotetext{
${ }^{274}$ BRASIL. Lei n. 7.797, de 10 de julho de 1989. Cria o Fundo Nacional de Meio Ambiente e dá outras providências. Brasília: 1989.

${ }^{275}$ LEUZINGER, 2009, p.107-108.

${ }^{276}$ BRASIL. Resolução Conama n. 1, de 23 de janeiro de 1986. Rio de Janeiro: 1986.

277 BRASIL. Resolução Conama n. 11, de 3 de dezembro de 1987. Rio de Janeiro: 1987. Em 1988, foi incorporada uma nova categoria, a das Áreas de Relevante interesse ecológico (ARIE'S) BRASIL. Resolução Conama n. 12, de 14 de dezembro de 1988. Rio de Janeiro: 1988.

${ }^{278}$ BRASIL. Decreto n. 98.897, de 30 de janeiro de 1990. Dispõe sobre as reservas extrativistas e dá outras providências. Brasília: 1990.
} 
renováveis por população extrativista"279. De acordo com Vianna "diferentemente das demais categorias de manejo, a motivação da criação das Resex's resultou da reivindicação do movimento social dos seringueiros da Amazônia, que buscavam resolução para suas questões fundiárias ${ }^{\text {280 }}$.

Também, nos anos 1990, foram retomados os estudos para a implantação de um Sistema Nacional das Unidades de Conservação

\subsubsection{Evolução e Consolidação do Sistema Nacional de Unidades de Conservação: 1989 a 2000}

Como vimos, estes estudos, já tinham sido objeto de duas versões do Plano do Sistema de Unidades de Conservação do Brasil - PSUC elaboradas pelo IBDF, em 1979 e 1982.

No final dos anos 1980 o governo federal propôs uma revisão e atualização do Plano, que obedeceria 3 fases: revisão do conceito de Unidade de Conservação e legalização das UC's existentes; análise da representatividade do Sistema (em termos dos ecossistemas protegidos); e, por último, elaboração de diretrizes e estratégias para a efetiva implementação do Sistema ${ }^{281}$.

Para a elaboração do projeto de lei sobre unidades de conservação, o CONAMA, através da Resolução n ${ }^{\circ}$ 10, de 1986, propôs a criação de uma Comissão Especial. Na resolução ficou determinado que a comissão fosse composta por uma equipe de conselheiros: Alte. Ibsem de Gusmão Câmara (representante FBCN), José Pedro de Oliveira Costa (representante do Governo do Estado de São Paulo), e Roberto Ribas Lange (representante da Associação de Defesa e Educação Ambiental ADEA) $)^{282}$.

A primeira fase do Projeto foi implementada pela FUNATURA. E, em 1988, o Ibama e a FUNATURA apresentaram uma proposta intitulada "Sistema Nacional de

\footnotetext{
${ }^{279}$ Id.

${ }^{280}$ VIANNA, 2008, p. 177. Vianna cita Santilli: “A proposta de Resex foi formulada inicialmente como projeto de assentamento extrativista e incluída no Programa Nacional de Reforma Agrária, em 1987, como uma alternativa aos projetos de colonização do Incra, que contemplasse as formas de ocupação da terra por populações tradicionais da Amazônia e respeitasse o extrativismo (principalmente de borracha e castanha), atividade centrada nas colocações [...] a proposta de Resex surgiu no contexto da luta pela reforma agrária e a partir de mobilizações sociais e políticas realizadas inicialmente pelos seringueiros do vale do rio Acre, especialmente no município de Xapuri, no Acre, sob a liderança de Chico Mendes".

281 FUNATURA. Sistema Nacional de Unidades de Conservação - SNUC: aspectos conceituais e legais. Brasília: IBAMA, FUNATURA, 1989, p. III.

282 BRASIL. Resolução Conama n. 10, de 10 de março de 1986. Rio de Janeiro: 1986.
} 
Unidades de Conservação (SNUC) - aspectos conceituais e legais", assinada pela coordenadora geral, Maria Tereza Jorge Pádua, então presidente da ONG. De acordo com o documento, o texto final foi resultado de muitas reuniões com especialistas na área da conservação da natureza ${ }^{283}$, técnicos do antigo IBDF e da SEMA, e ainda da realização de um seminário aberto para a discussão do tema com um número amplo de especialistas do país ${ }^{284}$.

O documento, publicado pela FUNATURA em 1989, apresenta definições de conceitos importantes, como o de Unidades de Conservação e de Sistema Nacional de Unidades de Conservação. As Unidades de Conservação foram definidas como porções do território nacional, incluindo as águas territoriais, com características naturais de valor relevante, sendo de domínio público ou privado, legalmente instituídas pelo poder público, com objetivos e limites definidos. Enquanto o Sistema Nacional de Unidades de Conservação - SNUC foi conceituado como o conjunto de unidades devidamente selecionadas, que atendessem da forma mais ampla possível aos objetivos nacionais de conservação da natureza, com destaque para a proteção de parcela significativa de todos os ecossistemas naturais existentes no país ${ }^{285}$.

De acordo com o documento poderiam existir diferentes tipos de áreas protegidas, mas apenas aquelas especificamente examinadas e homologadas formalmente pelo Órgão Superior do Sistema Nacional do Meio Ambiente integrariam o sistema. Também havia a exigência que esses espaços atendessem aos objetivos nacionais de conservação da natureza, para que pudessem caracterizar adequadamente as várias categorias de Unidades de Conservação, de acordo com suas finalidades próprias.

Os objetivos básicos de manejo das unidades foram definidos com base nas seguintes características: preservação da diversidade biológica; preservação e/ou restauração de amostras dos diversos ecossistemas naturais; proteção de espécies raras, endêmicas, vulneráveis ou em perigo de extinção; continuação do fluxo genético entre áreas protegidas; preservação e manejo de recursos da flora e/ou fauna; proteção das paisagens e belezas cênicas notáveis; proteção de sítios naturais com características

\footnotetext{
${ }^{283}$ De acordo com o documento, a Funatura contou com o assessoramento de seis (e não três como previu a Resolução Conama no 10 ) especialistas na área da conservação da natureza: Almte. Ibsen de Gusmão Câmara, Prof. Miguel Serediuk Milano, Prof. Jesus Manuel Delgado M., Dra. Ângela Tresinari Bernardes, Dr. César Vitor do Espírito Santo, e Dr. José Pedro de Oliveira Costa, sob a coordenação geral de Maria Tereza Jorge Pádua.

${ }^{284}$ FUNATURA, 1989. p.V.

${ }^{285}$ Id., p. 15
} 
abióticas excepcionais; proteção de bacias e recursos hídricos; fomento da pesquisa científica e estudos; fomento da educação ambiental; estímulo a espaços para recreação em contato com a natureza; contribuição para o monitoramento ambiental; incentivo ao uso sustentável dos recursos naturais; estímulo ao desenvolvimento regional através da conservação; atuação como zona-tampão para áreas mais rigidamente protegidas; e, preservação provisória de áreas para uso futuro ${ }^{286}$.

Nessa perspectiva chegou-se a um conjunto de nove categorias organizadas em três grupos, segundo o grau de proteção e seus respectivos atributos naturais.

O primeiro grupo, de Unidades de Proteção Integral englobou as categorias: Reserva Ecológica, Parque Nacional, Estadual ou Parque Natural Municipal, Monumento Natural, Refúgio da Vida Silvestre e Reserva de Recursos Naturais.

O segundo grupo, de Unidades de Manejo Provisórias, classificou apenas as Reservas de Recursos Naturais.

O terceiro grupo, de Unidades de Manejo Sustentável, contemplou as Reservas de Fauna, as Áreas de Proteção Ambiental, as Florestas Nacionais, Estaduais e Municipais e, as Reservas Extrativistas ${ }^{287}$ (ver detalhes na Tabela 8, em anexo).

De acordo com o documento elaborado pela FUNATURA, as várias categorias de manejo das unidades de conservação se justificavam pela criação, ao longo dos anos, de muitos tipos de áreas protegidas, a maioria delas com objetivos semelhantes. Sugeriu-se então, o agrupamento das áreas, com base no modelo de categorias propostas pela UICN, com adaptações convenientes às especificidades brasileiras ${ }^{288}$.

Ao analisarmos as categorias de manejo propostas pelo documento, consideramos que foi notável a importância dada às categorias de manejo de proteção integral - que não permitiam a ocupação humana - mostrando uma postura ainda muito presente nos órgãos gestores das Unidades de Conservação no país. Outros dois autores - Brito (2003) e Morsello (2008) - que se detiveram neste tema, também chamam a atenção para a valorização que o projeto faz da conservação biológica ${ }^{289}$ e para a conservação da biodiversidade ${ }^{290}$.

\footnotetext{
286 Ibid., p. 23-24.

287 Como o principal objetivo era a elaboração de um anteprojeto de lei que estabelecesse um Sistema Nacional de Unidades de Conservação, se diferenciando do I e II PSUC, o documento da Funatura não apresentou uma lista de UC's existentes, nem fez levantamento ou pesquisas para proposição de novas unidades.

${ }^{288}$ FUNATURA, 1989, p. 24.

${ }^{289}$ MORSELLO, 2008, p. 162.

${ }^{290}$ BRITO, 2003, p.67.
} 
Esta proposta de reorganização das categorias de manejo das unidades de conservação não chegou a ser implementada em 1989. Ela foi encaminhada ao Congresso Nacional em 1992 (Projeto de Lei n. 2.892) ${ }^{291}$, e somente em 2000, depois de várias alterações, foi instituído o Sistema Nacional de Unidades de Conservação da Natureza (SNUC), pela Lei no 9.985, onde ficaram estabelecidos critérios e normas para criação, implantação e gestão das unidades de conservação no país ${ }^{292}$.

De acordo com Castro Jr; Coutinho e Freitas:

\begin{abstract}
A tramitação do SNUC no Congresso Nacional levou oito anos, marcados por embates entre proprietários de terra, setores produtivos e ambientalistas, debates radicais entre preservacionistas e conservacionistas, atuação vigorosa dos movimentos ligados às populações tradicionais e uma discussão sobre o papel do controle social na gestão de unidades de conservação. Com forte influência dos conceitos preservacionistas, típicos do modelo norteamericano de conservação, o SNUC é promulgado em $2000[\ldots]^{293}$
\end{abstract}

Além da instituição do SNUC, conceitos importantes foram estabelecidos, como os de unidades de conservação, conservação da natureza, diversidade biológica, recurso ambiental, preservação, proteção integral, conservação in situ, manejo, uso indireto, uso direto, uso sustentável, extrativismo, dentre outros ${ }^{294}$.

Com a aprovação da lei, a gerência do SNUC ficou sob a responsabilidade do Ministério do Meio Ambiente - MMA (órgão central); através do CONAMA (órgão consultivo e deliberativo), que deveria acompanhar a implementação do sistema; do IBAMA e dos órgãos estaduais e municipais (órgãos executores), que teriam a função de implementar o SNUC, subsidiar as propostas de criação, e administrar as unidades de conservação federais, estaduais e municipais, nas respectivas esferas de atuação

De acordo com a Lei $\mathrm{n}^{\mathbf{0}}$ 9.985, as Unidades de Conservação (UC's) foram divididas em dois grupos, com características específicas: as Unidades de Proteção Integral, cujo objetivo baseava-se na preservação da natureza, permitindo apenas o uso indireto dos seus recursos naturais; e as Unidades de Uso Sustentável, que tinham como objetivo a compatibilização da conservação da natureza com o uso sustentável de parcela dos seus recursos naturais.

\footnotetext{
${ }^{291}$ MORSELLO, 2008, p.163.

${ }^{292}$ BRASIL. Lei n. 9.985, de 16 de julho de 2000. Regulamenta o artigo 225, Parágrafo 1 incisos I, II, III e VII da Constituição Federal, institui o Sistema Nacional de Unidades de Conservação da Natureza e dá outras providências. Brasília: 2000.

${ }^{293}$ CASTRO Jr.; COUTINHO e FREITAS, 2009, p.45.

${ }^{294}$ BRASIL. Lei n. 9.985, de 16 de julho de 2000. Regulamenta o artigo 225, Parágrafo 1 incisos I, II, III e VII da Constituição Federal, institui o Sistema Nacional de Unidades de Conservação da Natureza e dá outras providências. Brasília: 2000.
} 
As Unidades de Proteção Integral abrangeram cinco categorias de manejo: Estação Ecológica, Reserva Biológica, Parque Nacional, Monumento Natural e Refúgio de Vida Silvestre. Enquanto as Unidades de Uso Sustentável integraram sete categorias: Área de Proteção Ambiental, Área de Relevante Interesse Ecológico, Floresta Nacional, Reserva Extrativista, Reserva de Fauna, Reserva de Desenvolvimento Sustentável e, Reserva Particular do Patrimônio Natural. Todas as categorias de manejo tinham objetivos e características específicas, como pode ser observado na Tabela 9, em anexo.

Vale destacar que, no ano de 2007, foi criado o Instituto Chico Mendes de Conservação da Biodiversidade (ICMBio), por meio da Medida Provisória no 366, de 26 de abril de 2007, convertida na Lei $\mathrm{n}^{\circ}$ 11.516, de 28/08/2007. O Instituto foi criado como uma autarquia vinculada ao MMA e integrante do SISNAMA. Ao novo instituto foi atribuída a competência da execução das ações federais da política nacional de unidades de conservação: proposição, implantação, gestão, proteção, fiscalização e monitoramento das UCs federais ${ }^{295}$.

Desta forma, como fora no período de atuação conjunta do IBDF e da SEMA (1975 a 1989), o Brasil passou a contar novamente com duas agências ambientais distintas. O IBAMA, responsável pela política relacionada às unidades de conservação; e outra, o ICMCBio responsável pela atividade de polícia ambiental, pelo controle da qualidade ambiental, pela autorização de uso dos recursos naturais e pela fiscalização, monitoramento e controle ambiental. Além da execução de ações supletivas de competência da União ${ }^{296}$.

\subsubsection{Evolução das Unidades de Conservação de 1986 a 2000}

Como vimos no período de 1937 a 1948 foram criadas cinco UC's, quatro Parques Nacionais e uma Floresta Nacional. Três delas se concentravam nas regiões Sudeste e Sul, bioma da Mata Atlântica, e duas na região Nordeste, bioma da Caatinga,

\footnotetext{
${ }^{295}$ BRASIL. Lei n. 11.516, de 28 de agosto de 2007. Dispõe sobre a criação do Instituto Chico Mendes de Conservação da Biodiversidade - Instituto Chico Mendes; altera as Leis $\mathrm{n}^{\mathrm{os}} \mathbf{7 . 7 3 5}$, de 22 de fevereiro de 1989, 11.284, de 2 de março de 2006, 9.985, de 18 de julho de 2000, 10.410, de 11 de janeiro de 2002, 11.156, de 29 de julho de 2005, 11.357, de 19 de outubro de 2006, e 7.957, de 20 de dezembro de 1989; revoga dispositivos da Lei no 8.028, de 12 de abril de 1990, e da Medida Provisória no 2.216-37, de 31 de agosto de 2001; e dá outras providências. Brasília: 2007.

${ }^{296}$ LEUZINGER, 2009, p.113.
} 
acompanhando o processo de ocupação e exploração do espaço. Ao todo cobriram um total de $2.624,01 \mathrm{Km}^{2}$.

Já entre 1959 e 1961, foram implantadas no país doze áreas protegidas, a maioria na categoria parque. Foram onze Parques Nacionais e uma Floresta Nacional, abrangendo 26.333,87 $\mathrm{km}^{2}$. As unidades criadas ficaram concentradas no Bioma da Mata Atlântica, e no Cerrado. Este período foi marcado pela rápida destruição da floresta conduzida pela expansão da fronteira agrícola para a região Centro-Oeste e pela construção de Brasília, nova capital.

Entre 1968 a 1985, durante o regime militar, o número de UC's criadas chegou a setenta e sete, distribuídas em vários biomas do país, cobrindo uma área de 14.901.821,42 hectares, isto é, 149.018,21 $\mathrm{Km}^{2}$. Em termos de cobertura territorial a região amazônica foi a que mais protegeu, com 78,4\% do total do período. Neste período, as políticas de ocupação foram direcionadas para a região amazônica, e como aconteceu nas demais regiões do país, as unidades de conservação foram aparecendo, como forma de atenuar os grandes desmatamentos e de proteger os espaços territoriais brasileiros, especialmente em áreas de fronteira.

De 1986 a 2000, período que estamos analisando, foi registrada a criação de noventa e duas UC's, cobrindo mais de vinte e dois milhões de hectares $(22.486 .051,54)$, o correspondente/ou a $224.860,51 \mathrm{Km}^{2}$ do país. Como mostra o gráfico 4, quase $35 \%$ das unidades criadas localizaram-se no bioma da Amazônia, e as demais nos biomas Marinho Costeiro, Mata Atlântica, Cerrado, Caatinga e, Pampa (ver detalhes das unidades desse período na Tabela 10, em anexo).

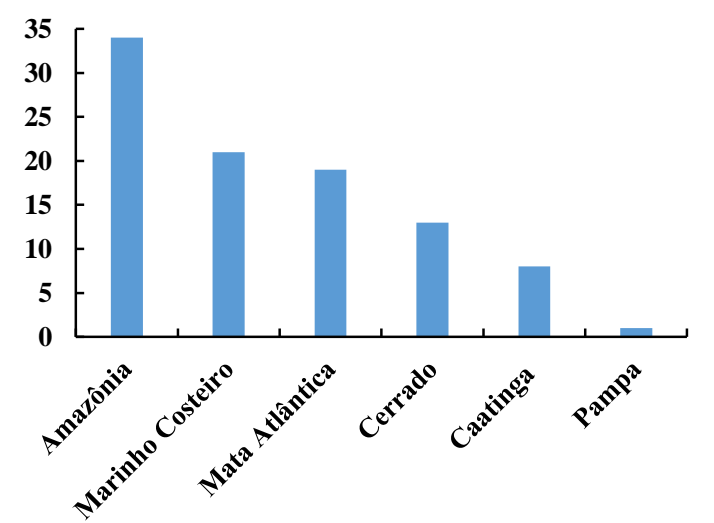

Gráfico 5 Número de Unidades de Conservação no Brasil, por Bioma: 1986 a 2000.

Fonte: Pesquisa da autora.

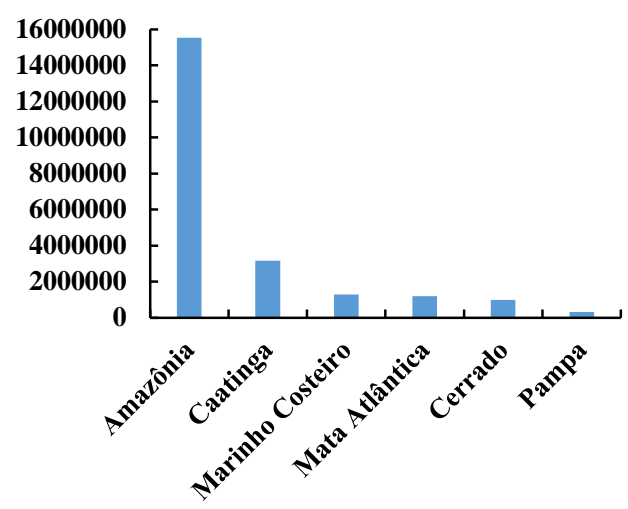

Gráfico 6 Tamanho (ha) das Unidades de Conservação no Brasil, por Bioma: 1986 a 2000. Fonte: Pesquisa da autora. 
No gráfico 6, destacamos o tamanho das unidades de conservação, do total de território protegido, novamente a região amazônica se sobressai, cobrindo mais de 15 milhões de hectares $(15.531 .393,87)$. Este valor representa $69,07 \%$ do total de áreas protegidas no período analisado.

Vemos assim também para este período que, sem dúvida, a região amazônica foi privilegiada na criação das unidades. Consideramos que este fato foi resultado da preocupação gerada no meio científico e em vários segmentos da população brasileira frente ao modelo de ocupação, iniciado na década de 1960 e que levou à destruição desenfreada das florestas na região. Sem dúvida, a ocorrência de conflitos pela posse da terra entre extrativistas e pecuaristas também repercutiu no país e a nível internacional. A morte do seringueiro e líder sindical, Chico Mendes, motivaram uma maior atenção ao que estava acontecendo na Amazônia.

\subsection{Algumas Considerações}

Neste capítulo, vimos que as primeiras unidades de conservação legalmente protegidas pelo poder público, a maioria na categoria Parque Nacional, assemelharamse ao modelo norte-americano, que tinha como principal objetivo a proteção das belezas cênicas, e usufruto da população urbana - fins turísticos. Gradativamente, outras categorias foram sendo criadas no país, assim como as políticas ambientais, que acompanharam os eventos internacionais de proteção à natureza.

$\mathrm{O}$ avanço das políticas ambientais no país, acompanharam as cobranças e regulamentos, sugeridos durante os eventos internacionais ligados a temática ambiental. Como exemplo, temos a implantação do primeiro Código Florestal brasileiro (1934), ocorrido logo após a Convenção de Londres (1933). Todas as outras legislações e órgãos implantados no período analisado, seguiram a mesma tendência.

O processo de categorização das unidades de conservação aconteceu de forma lenta. Somente a partir da década de 1970 é que o governo brasileiro tomou iniciativas para a implantação de um sistema nacional de unidades de conservação. Depois de mais trinta anos de estudos e trâmites legais, o Brasil aprovou em 2000, o Sistema Nacional de Unidades de Conservação, deixando claro as categorias de unidades de conservação, os tipos e formas de manejo. 
Analisando a influência internacional quanto a preservação do meio ambiente, podemos destacar que no processo de categorização das áreas protegidas em nível mundial, o Brasil contribuiu com a introdução de um tipo de área específica, as Reservas Extrativistas, que tiveram todo um contexto diferenciado das demais - a luta dos seringueiros, que queriam continuar trabalhando nas florestas com o extrativismo, contra os "novos" donos da terra, os fazendeiros. 


\section{CAPÍTULO 3}

\section{As Políticas de (Re)Ocupação para a Amazônia brasileira no Período Militar e a Criação das Primeiras Unidades de Conservação no Acre}

Com vimos, a criação das unidades de conservação no Brasil, acompanhou o processo de ocupação das regiões, iniciando-se no litoral, depois seguindo para o interior, no sentido leste para oeste. Na Amazônia não foi diferente, as políticas de ocupação dirigidas para esta região durante o regime militar, trouxeram junto a destruição de boa parte das florestas. Não obstante, foi também nesse período que a implantação das unidades de conservação cresceu de forma significativa.

Neste sentido, nosso objetivo, neste capítulo, é realizar uma análise das políticas de (re)ocupação para a região amazônica nos governos militares, afim de entender como se implantou um novo modelo de uso e ocupação das terras na região e como se deu a criação das primeiras unidades de conservação no território acreano.

\subsection{Localização Geográfica da Região Amazônica}

A Amazônia está situada na Região Centro-Norte da América do Sul, e ocupa áreas do território de nove países do continente: Brasil, Bolívia, Peru, Equador, Colômbia, Venezuela, Guiana, Suriname e Guiana Francesa. Em termos de tamanho, o Brasil abriga a maior parte deste bioma, o correspondente a 66\% (Mapa 1).

Em nosso país, a região ficou conhecida como "Amazônia Brasileira”, e depois de 1950 passou a denominar-se “Amazônia Legal”. Segundo Nádia Souza, um conceito essencialmente político, que aumentou para 1,3 milhão de $\mathrm{km}^{2}$ a área da Amazônia brasileira, através da incorporação de uma faixa de vegetação de transição, com cerca de 700 mil km² 297 .

Para Souza, o conceito de Amazônia Legal foi uma estratégia utilizada pelo governo federal para planejar e promover o desenvolvimento dessa grande região que tinha em comum a distância e o isolamento dos centros mais dinâmicos da economia do país, um conceito pautado por critérios econômicos e políticos, não prevalecendo aspectos puramente geográficos.

297 SOUZA, Nádia Simas. A Amazônia brasileira: processo de ocupação e a devastação da floresta. Boletim Científico ESMPU, Brasília, ano 9, n. 32/33, p. 199-235, jan./dez. 2010, p. 199. 


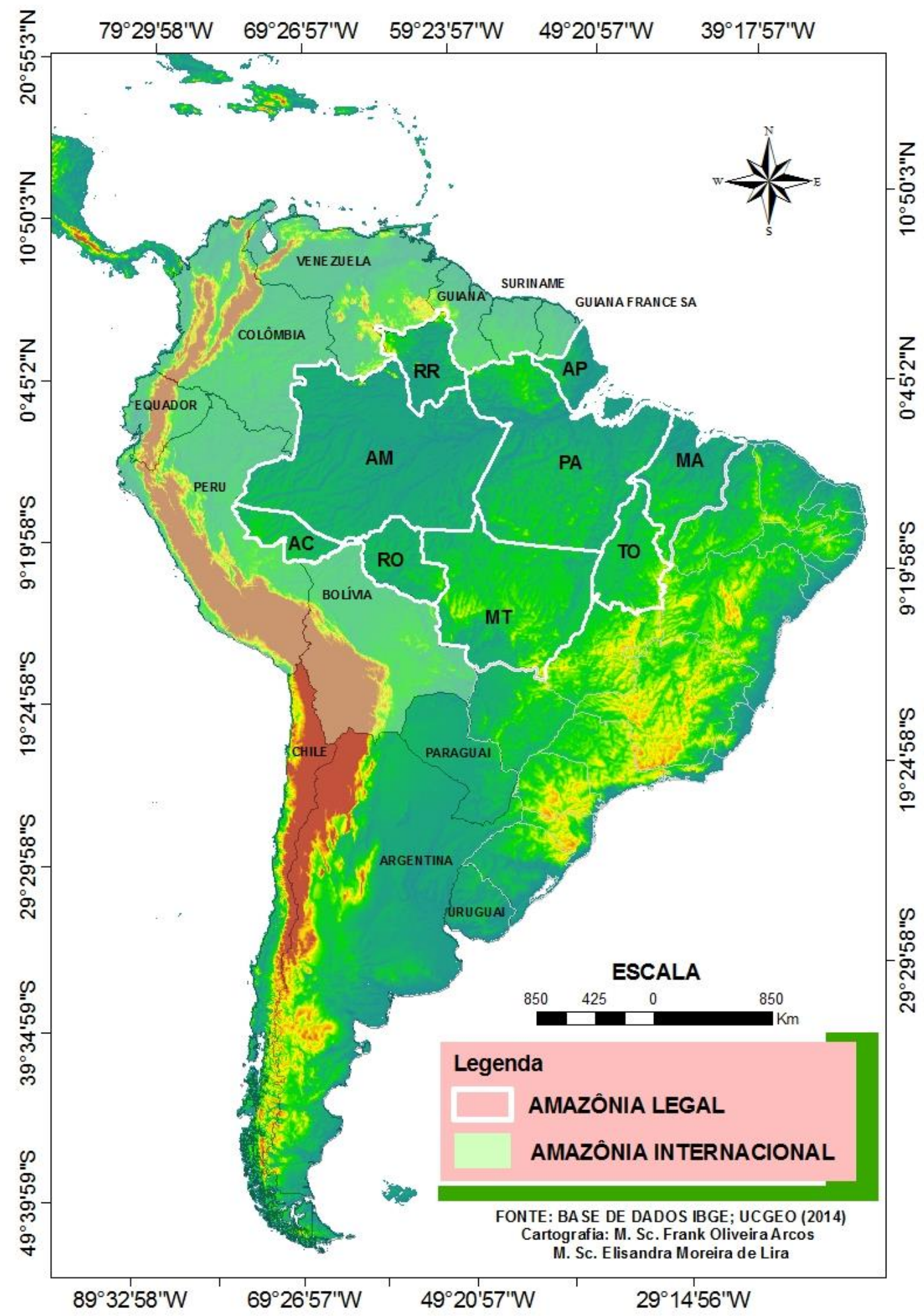

Mapa 1 Localização Geográfica da Amazônia Legal

Atualmente, a Amazônia Legal abrange todos os estados brasileiros pertencentes à Bacia Amazônica e aqueles que possuem ou tangenciam trechos da Floresta Amazônica. São eles: Amazonas, Pará, Amapá, Acre, Rondônia, Roraima, Tocantins, oeste do Maranhão e norte do Mato Grosso, que cobrem cerca de 5.217.423 
$\mathrm{km}^{2}$, aproximadamente $61 \%$ do território nacional, e possuem uma população em torno de vinte milhões de habitantes, a maioria (60\%) vivendo em áreas urbanas ${ }^{298}$.

\subsection{As Políticas dos governos militares de (re)ocupação para Amazônia Legal}

Segundo Becker, foi no período dos governos militares que deu-se início a um planejamento regional mais efetivo para a região amazônica. O Estado resolveu tomar para si a iniciativa de "um novo ordenado ciclo de devassamento amazônico num projeto geopolítico para a modernidade acelerada da sociedade e do território nacional ${ }^{299}$.

Já Hess, define esse período como de transição de um modelo "tradicional" de ocupação para um modelo "moderno". Para autora a forma tradicional era caracterizada por diferentes grupos sociais vivendo em estreita relação com a natureza, praticando o extrativismo da borracha, a coleta de castanha, a caça e a pesca, mantendo o equilíbrio ecológico. Por outro lado, o modelo moderno seria diferente, tanto na sua relação com a terra, - na medida em prevaleceu a especulação fundiária -, quanto em relação aos processos de produção, baseados na exploração maciça dos recursos naturais, especialmente, a madeira e os minérios ${ }^{300}$.

Para Hess, o modelo "moderno" de ocupação na Amazônia se consolidou no período dos governos militares que tinham como cerne a preocupação com a segurança nacional e o entendimento da Amazônia como um grande espaço "vazio", que precisava ser ocupado ${ }^{301}$. De acordo com Becker, para os militares, a ocupação da região também seria uma solução para as tensões sociais internas decorrentes da expulsão de pequenos produtores do Nordeste e do Sudeste, face a modernização da agricultura. Havia ainda a preocupação em nível continental, pois ocorria uma migração nos países vizinhos para suas respectivas amazônias, e a construção da Carretera Bolivariana Marginal de la Selva, uma artéria longitudinal que se estenderia pela face do Pacífico na América do

\footnotetext{
${ }^{298}$ INPE, 2004 apud Souza, 2010, p. 200.

${ }^{299}$ BECKER, Berta K. Síntese do Processo de Ocupação da Amazônia: lições do passado e desafios do presente. In: BRASIL. Ministério do Meio Ambiente. Causas e Dinâmica do Desmatamento na Amazônia. Brasília: MMA, 2001, p. 5-50. p. 8-9.

${ }^{300}$ HESS, Dora Rodrigues. Os Povos da Floresta, os Imigrantes e os Modelos de Ocupação Territorial: impactos e alternativas. Revista Brasileira de Geografia. v. 3, n. 52. Rio de Janeiro: IBGE, julho/setembro, 1990, p. 83-89. p. 83.

${ }^{301}$ HESS, 1990, p. 83.
} 
Sul (possibilitando trazer a Amazônia continental para a órbita do Caribe e do Pacífico, e por consequência reduzir a influência do Brasil no coração do continente). Além disso, a autora lembra a proposta dos norte-americanos do Instituto Hudson ${ }^{302}$, que pretendiam represar o rio Amazonas para a formação de um grande lago, a fim de criar um potencial para a geração de energia elétrica e facilitar a circulação e a exploração de recursos $^{303}$.

Segundo Maia, os militares viam o imenso território amazônico "quase da mesma forma que os espanhóis e portugueses na época da colonização”. Os colonizadores tinham a região como "tierras no descubiertas", enquanto os militares a viam como uma "terra sem gente para acomodar uma gente sem terras ${ }^{304}$. O autor refere-se aos sem-terra das regiões Sul, Sudeste e Nordeste, "que deveriam ser deslocados para os projetos de assentamento que seriam organizados visando integrar para não entregar' a Amazônia "305.

Ainda para Maia, a proposta de incorporação da Amazônia se enquadrava no que a historiografia denominou de "Grandes Projetos". Para ele, as visões geopolíticas e industrializantes, estavam concebidas dentro desse contexto, representadas pelo trinômio desenvolvimento, integração e segurança ${ }^{306}$.

Com estes objetivos, em $1^{\text {o }}$ de setembro de 1966 o governo Castelo Branco anunciava a chamada "Operação Amazônia" que, segundo Costa Sobrinho, foi resultado de uma reunião das instâncias dos governos federal, estaduais e municipais, realizada a bordo do navio Rosa da Fonseca, entre novembro e dezembro de 1966 (no decorrer de nove dias), ao navegarem o trajeto Manaus/Belém pelo rio Amazonas ${ }^{307}$. Na apresentação da Operação, o Presidente Castelo Branco falava em "Integrar para não Entregar” a Amazônia. Sua pretensão, segundo Souza, era enviar migrantes para a vasta

\footnotetext{
302 O Instituto Hudson, sem fins lucrativos, foi fundado, em 1961, por Herman Kahn, um estrategista militar, juntamente com seus amigos Max Cantor e Oscar Ruebhausen em Croton-on-Hudson, em Nova Iorque (Instituto Hudson. História. Disponível em: 〈http://www.hudson.org/about/history> Acesso em: 27 dez. 2014)

${ }^{303}$ BECKER, 2001, p. 9. Ver tb., VELHO, Otávio Guilherme. Capitalismo autoritário e campesinato. Rio de Janeiro: Difel, 1979, p. 212.

304 MAIA, José Sávio da Costa. A Florestania, o Desenvolvimento (in)sustentável e as Novas Fronteiras da Sóciodiversidade no Vale do Rio Acre na Virada do Século XX: o caso dos trabalhadores extrativistas. Tese (Doutorado em História). 353f. Universidade Federal do Rio Grande do Sul: Instituto de Filosofia e Ciências Humanas, 2009, p. 53.

${ }^{305}$ MAIA, 2009, p. 53.

${ }^{306}$ Id., p. 53.

${ }^{307}$ COSTA SOBRINHO, Pedro Vicente. Comunicação Alternativa e Movimentos Sociais na Amazônia Ocidental. João Pessoa: Editora Universitária/UFPB, 2001, p. 25.
} 
região, afim de demarcar o território, sinalizar limites para aos países vizinhos, demonstrando para o mundo que a Amazônia pertencia ao Brasil 308 .

Ainda segundo Souza, além da preocupação com a segurança, havia duas outras situações que justificavam a Operação Amazônia. Primeiro, existia a necessidade de deslocar uma parte da população da Região Nordeste, já que a seca e o solo desgastado, somados à concentração de terras em latifúndios, haviam produzido um número significativo de trabalhadores sem-terra. Em segundo lugar, a Região Sul, passava por conflitos de terra, decorrentes da mecanização da agricultura e também do aumento dos latifúndios, assim como no Nordeste, causando enorme tensão social ${ }^{309}$.

Para Maia, a Operação visava, por meio de uma abrangente ação do Estado, modernizar a economia regional de acordo com relações tipicamente capitalistas, que buscava o caminho da substituição de importações de bens industriais, entretanto mantendo a concentração na agropecuária e na agroindústria ${ }^{310}$.

Uma das primeiras providências do presidente Castelo Branco, para acelerar a ocupação regional e tornar exequível a "Operação Amazônia", foi a modernização de algumas instituições. Em 1966 foram extintos os organismos de proteção à borracha, como o Banco de Crédito da Borracha ${ }^{311}$ e a Superintendência do Plano de Valorização Econômica da Amazônia (SPVEA), e criados o Banco da Amazônia S/A (BASA) e a Superintendência para o Desenvolvimento da Amazônia (SUDAM) $)^{312}$.

Segundo Martins, a criação desses órgãos:

${ }^{308}$ SOUZA, 2010, p. 202.
${ }^{309}$ Id., p. 203.
${ }^{310}$ MAIA, 2009, p. 53-54; PAULA, Elder Andrade de. (Des)Envolvimento Insustentável na Amazônia Ocidental: dos missionários do progresso aos mercadores da natureza. Rio Branco: EDUFAC, 2005, p. 67.

${ }^{311}$ Este banco foi implantado em 1942, pelo Decreto-Lei no 4.451, de 9 de julho. Denominado Banco de Crédito da Borracha, seu objetivo baseava-se no desenvolvimento da produção da borracha e sua defesa econômica, bem como na execução do convênio celebrado em Washington, em 3 de março de 1942, entre o Governo Brasileiro e a Rubber Reserve Company, representante do Governo dos Estados Unidos da América. O Banco podia operar em todos os ramos de atividades bancárias no território nacional e prestar assistência financeira aos produtores e a pessoas físicas ou jurídicas que se dedicassem à extração e comércio de borracha e quaisquer outros produtos nativos. Também poderia incentivar o desenvolvimento de qualquer ramo da indústria de artefatos de borracha, no país (Decreto-Lei $\mathbf{n}^{\mathbf{0}}$ 9.720, de 3 de setembro de 1946). Já na década de 1950, o Banco passou a denominar-se Banco de Crédito da Amazônia S/A (Lei $\mathbf{n}^{\mathbf{0}}$ 1.164, de 30 de agosto de 1950), uma estratégia do governo de Juscelino Kubitschek que visava ampliar o financiamento a outras atividades produtivas da região para além da borracha, através do primeiro Plano de Valorização Econômica da Amazônia (SPVEA). O Plano de Valorização Econômica da Amazônia, previsto no Art. 199 da Constituição de 1946, se constituiu em um sistema de medidas, serviços, empreendimentos e obras, destinados a incrementar o desenvolvimento da produção extrativa e agrícola pecuária, mineral, industrial e das relações de troca, no sentido de melhorar os padrões sociais de vida e bem-estar econômico das populações da região e da expansão da riqueza do País (Lei no $\mathbf{1}^{\mathbf{1}} \mathbf{8 0 6}$, de 6 de janeiro de 1953).

312 HESS, 1990, p. 83. 
[...] preconizou uma política de concessão de incentivos fiscais aos empresários, especialmente das regiões mais ricas, para que deixassem de pagar 50\% do imposto de renda, desde de que o dinheiro fosse depositado naquele banco para financiar projetos de desenvolvimento na Amazônia, de cujo capital constituíram até $75 \%$. Os investimentos orientaram-se de preferência para a agropecuária, de modo que um grande número de empresários e de empresas, especialmente do Sudeste, sem tradição no ramo, tornaram-se proprietárias de terras de empresários rurais. Em princípio, a aquisição de terras pelos grandes capitalistas do Sudeste animou o mercado imobiliário, convertendo, por isso mesmo, os proprietários de terras em proprietários de dinheiro e forçando-os por sua vez, a agirem como capitalistas $^{313}$.

O BASA, criado através da Lei n. 5.122/66, ficou responsável por várias atribuições, dentre elas, podemos destacar: a execução da política do Governo Federal na Região Amazônica relativa ao crédito para o desenvolvimento econômico-social; a execução de operações bancárias em todas as suas modalidades, especialmente aquelas relacionadas com as atividades industriais, comerciais e produtoras da região; exercer as funções de agente financeiro da SUDAM; executar os serviços bancários de quaisquer órgãos federais, inclusive autarquias, nas localidades da Região Amazônica onde o Banco do Brasil S/A, não dispunha de agências; executar, paralelamente ao Banco do Brasil na Região Amazônica e como agente da Comissão de Financiamento de Produção, a política dos preços mínimos dos produtos agrícolas, pecuários ou extrativos $^{314}$.

Depois da criação do BASA, dando continuidade às intenções de desenvolver a economia da região e integrá-la à economia nacional, foi instituído um programa mais amplo através do Plano de Valorização Econômica da Amazônia, pela Lei no 5.173, de 1966. Entre os órgãos citados como agentes de elaboração, controle e execução do Plano de Valorização, estavam o BASA e a SUDAM.

O Plano tinha metas a serem alcançadas. Entre elas: a realização de programas de pesquisas e levantamento do potencial econômico da Região, como base para a ação planejada a longo prazo; a definição dos espaços econômicos suscetíveis de desenvolvimento planejado, com a fixação de polos de crescimento capazes de induzir o desenvolvimento de áreas vizinhas; a adoção de política imigratória para a Região, com aproveitamento de excedentes populacionais internos e contingentes selecionados externos; a fixação de populações regionais, especialmente nas zonas de fronteiras; o

\footnotetext{
${ }^{313}$ MARTINS, José de Souza. O Poder do Atraso: ensaios de sociologia da história lenta. São Paulo: Hucitec, 1994, p. 79.

${ }^{314}$ BRASIL. Lei $\mathbf{n}^{0} \mathbf{5 . 1 2 2}$, de 28 de setembro de 1966. Dispõe sobre a transformação do Banco de Crédito da Amazônia em Banco da Amazônia S.A. Brasília: 1966.
} 
ordenamento da exploração das diversas espécies e essências nobres nativas da região, inclusive através da silvicultura e aumento da produtividade da economia extrativista sempre que esta não pudesse ser substituída por atividade mais rentável; o incentivo e amparo à agricultura, à pecuária e à piscicultura como base de sustentação das populações regionais; a adoção de política intensiva de estímulos fiscais, creditícios; e a concentração da ação governamental nas tarefas de planejamento, pesquisa de recursos naturais, implantação e expansão da infraestrutura econômica e social, reservando para a iniciativa privada as atividades industriais, agrícolas, pecuárias, comerciais e de serviços básicos rentáveis ${ }^{315}$.

A SUDAM, com sede e foro na cidade de Belém-PA, ficou responsável por planejar, promover a execução e controlar a ação federal na região. E de acordo com Quintão, também se propunha a avaliar os recursos naturais da região e estudar a possibilidade de desenvolvimento das bases agriculturais e industriais já existentes ${ }^{316}$.

Entre as atribuições da SUDAM podemos destacar: a elaboração e fiscalização do Plano de Valorização Econômica da Amazônia, além da coordenação ou promoção de sua execução; fiscalização do emprego dos recursos financeiros destinados ao Plano; prestação de assistência técnica a entidades públicas na elaboração ou execução de programas ou projetos considerados prioritários para o desenvolvimento regional; dar sugestões de providências necessárias à criação, adaptação, transformação ou extinção de órgãos ou entidades; e promoção e divulgação de pesquisas, estudos e análises visando o reconhecimento sistemático das potencialidades regionais.

Ainda no âmbito da Lei que instituiu o Plano de Valorização Econômica da Amazônia, foi criado o Fundo para Investimentos Privados no Desenvolvimento da Amazônia (FIDAM), com o objetivo de executar com mais êxito as ações da SUDAM. Em 1967, com a publicação do Decreto n. 60.079, que aprovou o regulamento geral do Plano de Valorização Econômica da Amazônia, ficou registrado no artigo 40, que os recursos do FIDAM deveriam ser aplicados em financiamento da iniciativa privada, para investimentos declarados prioritários ao desenvolvimento da região, e para pesquisas que visassem o aproveitamento dos recursos naturais e agrícolas. Além disso, também ficou responsável por financiar a elaboração de projetos industriais decorrentes

\footnotetext{
${ }^{315}$ BRASIL. Lei ${ }^{\mathbf{0}}$ 5.173, de 27 de outubro de 1966. Dispõe sobre o Plano de Valorização Econômica da Amazônia; extingue a Superintendência do Plano de Valorização Econômica da Amazônia (SPVEA), cria a Superintendência do Desenvolvimento da Amazônia (SUDAM), e dá outras providências. Brasília: 1966.

${ }^{316}$ QUINTÃO, 1983, p. 21-22.
} 
de resultados das pesquisas consideradas positivas ${ }^{317}$. O que podemos observar é que a iniciativa privada sai privilegiada com mais recursos, impulsionando sua atração para a região.

Simultaneamente à criação do Plano de Valorização Econômica, foi regulamentada a concessão de incentivos fiscais na região, pela Lei n. 5174/66. Dessa forma, todas as pessoas jurídicas gozariam, até o exercício de 1982, de isenção do imposto de renda e quaisquer adicionais a que estivessem sujeitas, com relação aos resultados financeiros de empreendimentos econômicos na região ${ }^{318}$. Também, os empreendimentos instalados na data da publicação da lei, seriam beneficiados com isenção de 50\% (cinquenta por cento), e os demais que fossem legalmente instalados até o exercício financeiro de 1971, seriam contemplados em 100\% (cem por cento).

Finalizando a década de 60, ainda em 1967, o Decreto-Lei $\mathrm{n}^{\circ}$ 288/67 regulamentou a Zona Franca de Manaus ${ }^{319}$ (ZFM). De acordo com artigo $1^{\text {o }}$ do Decreto ficou estabelecido que a Zona Franca seria uma área de livre comércio de importação e exportação e de incentivos fiscais especiais, estabelecida com a finalidade de criar no interior da região amazônica um centro industrial, comercial e agropecuário dotado de condições econômicas que permitiriam seu desenvolvimento, em face dos fatores locais e da grande distância dos centros consumidores de seus produtos ${ }^{320}$.

Assim, a entrada de mercadorias estrangeiras na ZFM, destinadas ao consumo interno, industrialização e beneficiamento, agropecuária, pesca, instalação e operação de indústrias e serviços de qualquer natureza e a estocagem para reexportação, ficaram isentas dos impostos de importação. Destacando-se a exceção da isenção fiscal para armas e munições, perfumes, fumo, bebidas alcoólicas e automóveis de passageiros.

A administração das instalações e serviços da ZFM ficou a cargo da Superintendência da Zona Franca de Manaus (SUFRAMA), uma entidade autárquica,

\footnotetext{
317 BRASIL. Decreto $\mathbf{n}^{\mathbf{0}} \mathbf{6 0 . 0 7 9}$, de 16 de janeiro de 1967. Aprova o "Regulamento Geral do Plano de Valorização Econômica da Amazônia". Brasília: 1967.

${ }^{318}$ BRASIL. Lei $\mathbf{n}^{0}$ 5.174, de 27 de outubro de 1966. Dispõe sobre a concessão de incentivos fiscais em favor da Região Amazônica e dá outras providências. Brasília: 1966.

${ }^{319}$ A Zona Franca de Manaus, localizada na cidade de Manaus, Estado do Amazonas, foi criada em 06 de junho de 1957, através da Lei $\mathbf{n}^{\mathbf{0}}$ 3.173. O lugar era destinado ao armazenamento ou depósito, guarda, conservação, beneficiamento e retirada de mercadorias, artigos e produtos de qualquer natureza, provenientes do estrangeiro e destinados tanto ao consumo interno da Amazônia, como dos países interessados, limítrofes do Brasil ou que fossem banhados por águas tributárias do rio Amazonas. A Zona Franca foi considerada pelo governo um empreendimento coordenado com o Plano de Valorização Econômica da Amazônia.

${ }^{320}$ BRASIL. Decreto-Lei ${ }^{\mathbf{0}} \mathbf{2 8 8}$, de 28 de fevereiro de 1967. Altera as disposições da Lei número 3.173 de 6 de junho de 1957 e regula a Zona Franca de Manaus. Brasília, 1967.
} 
com personalidade jurídica e patrimônio próprio, autonomia administrativa e financeira, com sede e foro na cidade de Manaus, capital do Amazonas ${ }^{321}$.

Em 1970, para fortalecer ainda mais o processo de ocupação na região, o Presidente Emílio Médici lançou o Programa de Integração Nacional (PIN), por meio do Decreto-lei $\mathrm{n}^{\circ}$ 1.106/70 322 . Para Andreazza, Ministro dos Transportes, o PIN se definia nos seguintes termos:

\begin{abstract}
Integração Territorial em seus aspectos de efetiva posse de extensas áreas do nosso território, incorporando-as ao contexto nacional, através do desbravamento de áreas virgens e abertura de novas fronteiras de desenvolvimento econômico-social, mediante a construção de rodovias pioneiras que complementarão o sistema de navegação fluvial através de expansão da frota e da construção de terminais rodo-hidroviários nos pontos de conexão das rodovias com os cursos d'água, inserindo-se, assim, em um projeto integrado de criação de novos polos de atividades agrícolas, pastoris e de mineração ${ }^{323}$.
\end{abstract}

Segundo Duarte, o PIN tinha como meta imediata a construção de rodovias. As primeiras rodovias seriam a Transamazônica, que ligaria o Norte ao Nordeste; e a Cuiabá-Santarém, que ligaria o Norte ao Sul do país ${ }^{324}$. Além da função de ligação entre regiões, as rodovias poderiam impulsionar a colonização das faixas de terras nas suas laterais. Tais medidas, contribuíram para a abertura de estradas consideradas faraônicas na Amazônia, e, por conseguinte atraíram especuladores, grileiros, colonos e posseiros, intensificando assim os conflitos pela posse da terra na região ${ }^{325}$.

Em fevereiro de 1971, o Ministro do Interior General José Costa Cavalcanti anunciou que cerca de 12 mil quilômetros de rodovias federais estavam sendo

\footnotetext{
${ }^{321}$ Entre suas atribuições constava a elaboração do Plano Diretor Plurienal da ZFM e coordenação e, ou promoção da sua execução, diretamente ou através de convênio com órgãos ou entidades públicas inclusive sociedade de economia mista, ou ainda através de contrato com pessoas ou entidades privadas; a prestação de assistência técnica a entidades públicas ou privadas, na elaboração ou execução de programas de interesse para o desenvolvimento da Zona Franca; a manutenção de constante articulação com a SUDAM, com o Governo do Estado do Amazonas e autoridades do município em que se encontra a ZFM; a promoção e divulgação de pesquisas, estudos e análises que visassem o reconhecimento sistemático das potencialidades econômicas da Zona.

${ }^{322}$ BRASIL. Decreto-Lei $\mathbf{n}^{\mathbf{0}} \mathbf{1 . 1 0 6}$, de 16 de junho de 1970. Cria o Programa de Integração Nacional, altera a legislação do imposto de renda das pessoas jurídicas na parte referente a incentivos fiscais e dá outras providências. Brasília, 1970.

${ }^{323}$ ANDREAZZA, Mário. Programas especiais na área dos transportes: objetivos e execução. Rio de Janeiro: Companhia Brasileira de Artes Gráficas, 1972, p. 10.

${ }^{324}$ No ano de 1972, o Decreto-lei no 1.243 elevou as dotações do PIN, prorrogando a destinação de $30 \%$ das deduções, até 1975, incluindo também a construção da Rodovia Perimetral Norte e o prolongamento da Cuiabá-Santarém até a divisa do Brasil com Suriname.

${ }^{325}$ DUARTE, Élio Garcia. Conflitos pela Terra no Acre. Rio Branco: Casa da Amazônia, 1987, p. 50.
} 
implantadas na Amazônia, como prioridade no plano de ocupação e integração do Governo. Então, ele comentou que:

Entre as rodovias federais situadas na Amazônia, destacam-se: BR-010 (Belém-Brasília), com $1.901 \mathrm{~km}$; BR-156 (Macapá-Fronteira da Guiana Francesa), com 676 km; BR-174 (Manaus-Fronteira com Venezuela), com 970 km; BR-236 (Abunã-Fronteira com o Peru), com 1.108 km; BR-310 (Manaus-Guajará-Mirim), com 1.107 km; BR-364 (Cuiabá-Porto Velho), com 1.384 km; BR-317 (Brasiléia-Lábrea), com 879 km; BR-316 (BelémPeritoró), com 742 km; BR-165 (Cuiabá-Santarém), com 1.618 km; e a Transamazônica, em sua primeira etapa, com $1.290 \mathrm{~km}$, correspondentes ao trecho Porto Franco, no Maranhão, a Itaituba, no Pará ${ }^{326}$.

Segundo o Ministro, os principais fatores que levaram o Governo Federal a executar essas obras rodoviárias de vulto, foram os aspectos fisiográficos, demográficos, econômicos e sociais das regiões norte e nordeste.

[...] De um lado, a Amazônia, rica em recursos naturais e demograficamente vazia. Do outro lado, o Nordeste, constituído, em grande maioria, por um sertão semiárido, onde se agita uma população superior a 30 milhões de habitantes favoráveis à pecuária, à agricultura e à mineração, essas rodovias poderão repetir o sucesso da Belém-Brasília, (...), cortando regiões antes desconhecidas do homem, em 10 anos de funcionamento $[\ldots]^{327}$.

A tabela a seguir nos mostra o resultado do "sucesso" da rodovia BelémBrasília, que atravessou várias regiões, resultando no aumento da população, número de cidades e povoados, e no desenvolvimento das atividades agropecuárias.

Tabela 11 Alterações Socioeconômicas com a implantação da rodovia Belém-Brasília: 1960-1970

\begin{tabular}{|c|c|c|}
\hline Dados & Situação em 1960 & Situação em 1970 \\
\hline População* & 100.000 habitantes & 2.000.000 habitantes \\
\hline $\begin{array}{l}\text { Número de cidades e } \\
\text { povoados }\end{array}$ & 10 & 120 \\
\hline Rebanho bovino & Inexpressivo & 5.000 .000 reses \\
\hline Agricultura & De subsistência & Culturas intensivas de milho, feijão, arroz e algodão \\
\hline $\begin{array}{l}\text { Médias diárias de } \\
\text { tráfego }\end{array}$ & Praticamente inexistente & $\begin{array}{l}700 \text { veículos no trecho inicial sul Anápolis-Ceres- } \\
\text { Uruaçu; } 350 \text { veículos no trecho intermediário Uruaçu- } \\
\text { Porangatu e Gurupi; } 300 \text { veículos no trecho restante; } \\
\text { até a zona de influência de Belém, quando esse índice } \\
\text { se eleva acentuadamente. }\end{array}$ \\
\hline Estradas vicinais & Inexistentes & $2.300 \mathrm{~km}$, em implantação acelerada \\
\hline
\end{tabular}

${ }^{326}$ Bol. Geogr., ano 30, n. 220, p. 1-94. Rio de Janeiro: IBGE, jan/fev, 1971, p. 176.

${ }^{327}$ Id. 
Ao observarmos a Tabela 11, fica evidente que as políticas para ocupação da região, de certa forma deram certo. Todavia, os objetivos de atender os considerados sem-terra, ficaram de lado. A população aumentou e o número de povoados também, assim como as estradas para facilitar o tráfego de veículos. O que não podemos deixar de destacar foi o ritmo de crescimento da atividade pecuária, que em 1960 era inexpressivo e, em 1970, já contabilizava 5.000.000 de reses.

A outra linha de ação do governo federal dizia respeito à questão fundiária. Ainda em 1970, foi instituído o Instituto Nacional de Reforma Agrária (INCRA), através do Decreto-lei n. 1.110/70, com o objetivo de promover e executar a reforma agrária. Segundo o Decreto, esta ação visava “corrigir a estrutura agrária do país, adequando-a aos interesses do desenvolvimento econômico e social; promover, coordenar, controlar e executar a colonização; e promover o desenvolvimento rural através da coordenação, controle e execução, preferencialmente, das atividades de cooperativismo, associativismo e eletrificação rural" ${ }^{328}$.

A continuidade desta ação se deu em 1971, pelo Decreto-lei $\mathrm{n}^{\circ} 1.179$ que criava o Programa de Redistribuição de Terras e de Estímulo à Agroindústria do Norte e Nordeste (PROTERRA), que tinha por objetivo "promover o acesso do homem à terra, criar empregos e fomentar a agroindústria nas regiões norte e nordeste”. De acordo com o Decreto-lei 20\%, das deduções do imposto de renda deveriam ser destinadas ao PROTERRA, pelo período de cinco anos (1972 a 1976) ${ }^{329}$.

Entretanto, segundo Duarte, o objetivo do PROTERRA de promover o acesso do homem à terra não teve êxito. O Fundo de Redistribuição de Terras, criado pelo Decreto $n^{\circ} 70.677$ de 1972, que regulamentou a aplicação dos recursos destinados ao PROTERRA $^{330}$, contou com apenas $25 \%$ de seus recursos em 1972, enquanto $65 \%$ foram destinados a projetos de fortalecimento da infraestrutura agrícola e ao financiamento de projetos de expansão e modernização da agricultura, pecuária e agroindústria. E, outros $10 \%$ foram usados para ações discriminatórias, fiscalização da posse e uso da terra, extensão rural, assistência ao cooperativismo, colonização e outras

\footnotetext{
${ }^{328}$ BRASIL. Decreto-Lei $\mathbf{n}^{\mathbf{0}}$ 1.110, de 09 de julho de 1970. Cria o Instituto Nacional de Colonização e Reforma Agrária (INCRA), extingue o Instituto Brasileiro de Reforma Agrária, o Instituto Nacional de Desenvolvimento Agrário e o Grupo Executivo da Reforma Agrária e dá outras providências. Brasília: 1970.

${ }^{329}$ BRASIL. Decreto-Lei no 1.179, de 6 de julho de 1971. Institui o Programa de Redistribuição de Terras e de Estímulo à Agro-indústria do Norte e do Nordeste (PROTERRA), altera a legislação do imposto de renda relativa a incentivos fiscais e dá outras providências. Brasília, 1971.

${ }^{330}$ BRASIL. Decreto no 70.677, de 6 de junho de 1972. Dispõe sobre a execução do Decreto-lei no ${ }^{\circ} .971$, que institui o PROTERRA. Brasília, 1972.
} 
atividades correlatas $^{331}$. O próprio Ministro da Agricultura, Moura Cavalcanti, reconheceu, em reunião realizada em 1973, que foram poucas as redistribuições feitas. Segundo Duarte, então, ele relatou que a redistribuição beneficiou especuladores, e que foram feitas manobras para obtenção de lucros com as terras que seriam distribuídas pelo programa ${ }^{332}$.

A intenção do governo de favorecer as grandes empresas ficou mais evidente durante um encontro realizado na Amazônia, dos Ministros do Planejamento, da Agricultura e do Interior, com os maiores empresários da região Sul, onde eles declararam a intenção do governo de apoiar a formação de grandes consórcios empresariais para a região, em propriedades com área em torno de 100 mil hectares ${ }^{333}$.

O gráfico 7, construído com dados do IBGE editados em 2007, nos mostra realmente que, no período dos governos militares, o número de estabelecimentos agropecuários só aumentou. Em 1970, já atingia a cifra de 261.145 estabelecimentos e, em 1985, no final do regime militar, o número já ultrapassava os 500.000 de estabelecimentos. Desde o início de 1970 até o final do regime militar, em 1985, quase duplicou, o acréscimo em números de estabelecimentos agropecuários foi de 282.568 .

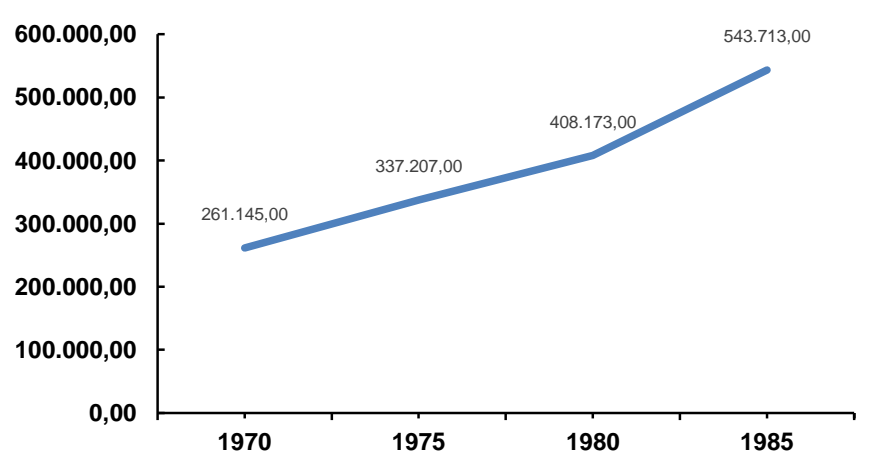

Gráfico 7 Números de Estabelecimentos Agropecuários na região Norte no período militar (em hectares) Fonte: Estatísticas do Século XX. Rio de Janeiro: IBGE, 2007. Disponível em http://seriesestatisticas.ibge.gov.br/ Acesso em: 31 dez. 2014.

No gráfico 8 a seguir, podemos observar que os tamanhos dos estabelecimentos sofrem variações ao longo do regime militar.

De acordo com os dados do gráfico, o número de estabelecimentos agropecuários com menos de 100 hectares, não mostrou grande variações. Permaneceu com uma média de $18,44 \%$ do total de estabelecimentos, durante todo o período militar.

\footnotetext{
${ }^{331}$ DUARTE, 1987, p. 50.

332 Id., p. 51.

${ }^{333}$ Ibid., p. 51.
} 
Entretanto, o mais expressivo foi o que aconteceu com os estabelecimentos que possuíam uma área igual ou superior a 1000 hectares. Depois de lançadas as principais políticas de incentivos fiscais, o número de estabelecimentos com este tamanho foi superior a $80 \%$, do total contabilizado em 1975, e depois esta categoria continuou sendo a de maior representatividade, quando comparada aos outros estabelecimentos com área inferior.

No gráfico a seguir, podemos observar que os tamanhos dos estabelecimentos sofrem variações ao longo do regime militar.

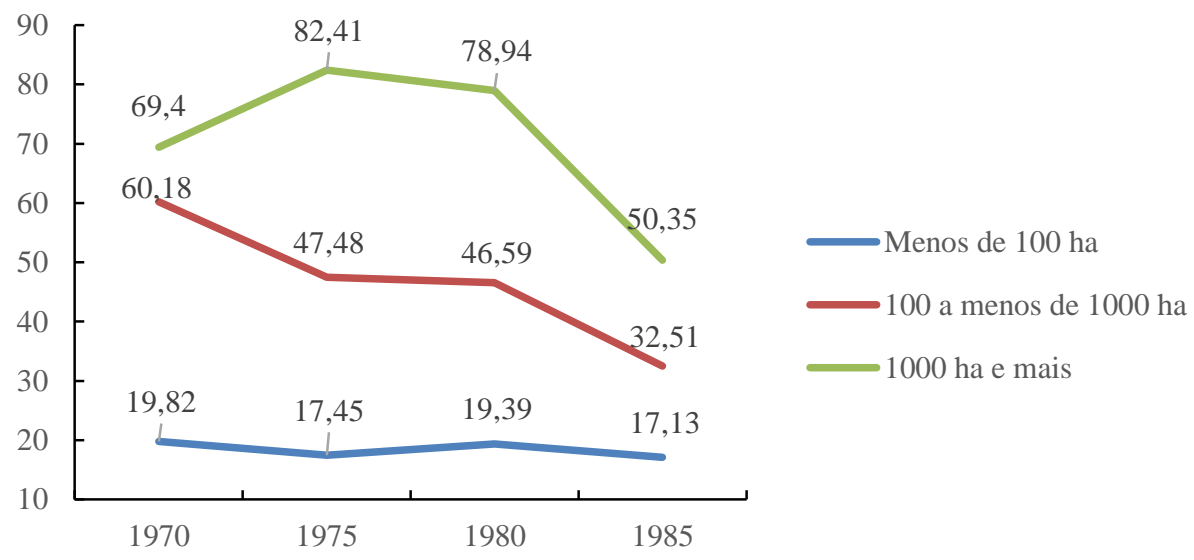

Gráfico 8 Tamanho dos Estabelecimentos Agropecuários (em percentual) na região Norte:1970 a 1985.

Fonte: Estatísticas do Século XX. Rio de Janeiro: IBGE, 2007. Disponível em http://seriesestatisticas.ibge.gov.br/ Acesso em: 31 dez. 2014.

Também podemos relacionar os dados do gráfico 8 com os do gráfico 9. Pois no período analisado, observamos um grande número de estabelecimentos com área igual ou superior a 1000ha, tamanhos ideais para o investimento na pecuária.

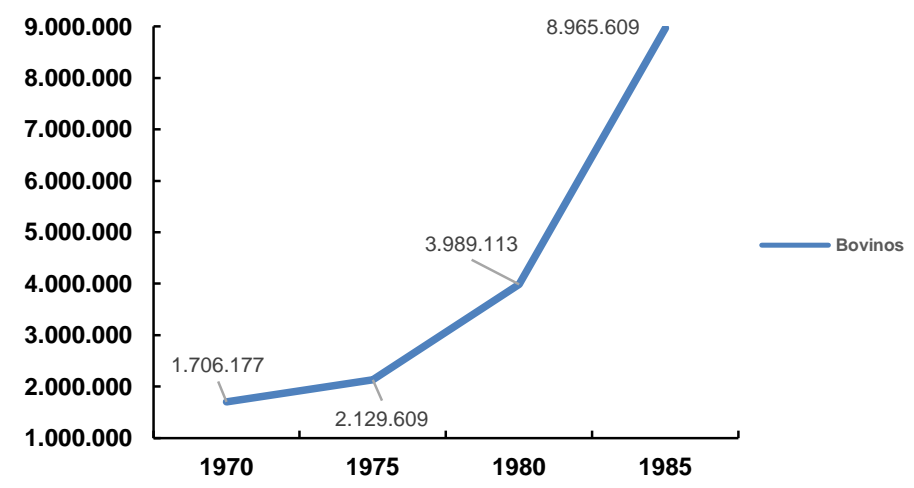

Gráfico 9 Efetivo de Bovinos (por cabeça) na região Norte no período militar

Fonte: Estatísticas do Século XX. Rio de Janeiro: IBGE, 2007. Disponível em http://seriesestatisticas.ibge.gov.br/ Acesso em: 31 dez. 2014. 
Os dados do IBGE, nos mostram um crescimento acelerado dos investimentos na pecuária bovina. Em 1970 o quantitativo de animais por cabeça já estava próximo a dois milhões, e esse número só aumentou ao longo dos anos. Em 1975, eram contabilizadas 2.129.609 de cabeças; em 1980, 3.989.113 de cabeças; e, em 1985, chegava-se a quase 9.000.000 (8.965.609 de cabeças).

Esses dados também são resultado do Programa de Polos Agropecuários e Agrominerais da Amazônia (POLAMAZÔNIA), lançado em 1974. O Programa tinha por finalidade promover o aproveitamento integrado das potencialidades agropecuárias, agroindustriais, florestais e minerais, com a implantação de quinze polos de desenvolvimento em áreas prioritárias da Amazônia ${ }^{334}$. Para tanto, o POLAMAZÔNIA passou a receber investimentos oriundo do PIN, do PROTERRA e do Fundo de Desenvolvimento de Programas Integrados (F.D.P.I), para os exercícios de 1974 a $1977^{335}$.

De acordo com Decreto 74.607/75, que criou o POLAMAZÔNIA, para cada uma das áreas prioritárias indicadas, deveria ser elaborado um Plano de Desenvolvimento Integrado (PDI), que especificaria a programação de investimentos públicos orientados principalmente para viabilizar a implementação, nas mesmas áreas, de atividades produtivas de responsabilidade da iniciativa privada. Neste sentido, os PDI's deveriam contemplar a elaboração do zoneamento adequado do uso dos recursos naturais, bem como a destinação de áreas para reserva florestais e biológicas, parques nacionais e reservas indígenas.

No entanto, a existência de órgãos, como o INCRA, e de programas voltados para a implantação da reforma agrária, não conseguiram fazer frente ao processo de concentração fundiária. Em 1980, o Diretor do Departamento de Recursos Fundiários do INCRA, Odair Zanatta, em depoimento à CPI da Amazônia, declarou que grupos empresariais do centro sul do País adquiriram áreas já ocupadas por posseiros. Algumas com titulações ilegítimas. E para agravar a situação ele comentou que:

Os Estados cujas áreas integram total ou parcialmente a Amazônia Legal tinham alienado, até 1970, sem se cercarem das devidas cautelas, terras que não haviam previamente discriminado, ferindo as disposições da Lei Federal e da sua própria legislação, de juridicidade e constitucionalidade discutíveis. Os Governos Estaduais, sem levar em conta o fato de que essas terras se

334 Xingu-Araguaia; Carajás; Araguaia-Tocantins; Trombetas; Altamira; Pré-Amazônia Maranhense; Rondônia; Acre; Juruá Solimões; Roraima; Tapajós; Amapá; Juruena; Aripuanã; e Marajó.

335 BRASIL. Decreto $\mathbf{n}^{\mathbf{0}}$ 74.607, de 25 de setembro de 1974. Dispõe sobre a criação de Pólos Agropecuários e Agrominerais da Amazônia (POLAMAZÔNIA). Brasília, 1974. 
encontravam densamente ocupadas, vendiam-na a particulares. Alienaram-se, por exemplo, terras ocupadas por posseiros que nelas residiam há mais de 20 (vinte) anos, ou terras que o próprio Estado já tinha, através de lei, dado outra destinação ${ }^{336}$.

Neste ínterim, explodiam os conflitos por todas as regiões, especialmente na Amazônia. E as grandes empresas que já vinham se apoderando das terras da região, passaram a adquirir terras diretamente do INCRA, como citado no documento da Conferência Nacional dos Bispos do Brasil (CNBB) de 1977:

[...] com o governo Geisel, houve mudanças de política do INCRA [...] apossou-se dessas terras (faixas marginais das rodovias federais da região EGD) com o fim claro de colonização e Reforma Agrária, visando beneficiar os trabalhadores rurais sem-terra, notadamente do Nordeste.

Todavia, agora, o INCRA passou a vender essas terras a grandes empresas, a preços baixíssimos.

[...] Constata-se, pois, que essa mudança na orientação do INCRA nada mais faz que compatibilizá-la com a linha que sempre orientou o governo na ocupação da Amazônia: o privilégio das grandes empresas ${ }^{337}$.

Segundo Duarte, a própria CPI da Amazônia, instalada no Congresso Nacional em 1980, constatou que tanto o POLAMAZÔNIA quanto o PROTERRA fracassaram em sua principal finalidade, que era a de fomentar a infraestrutura em regiões prioritárias da Amazônia e de viabilizar a distribuição de terras e de créditos a pequenos produtores no Norte e Nordeste. Ao contrário, na maioria dos casos, seus recursos acabaram sendo utilizados pelos grandes empresários ${ }^{338}$.

\begin{abstract}
Apesar de tanta confusão reinante na legislação, da indefinição de grande parte dos programas elaborados para a Amazônia, das disputas internas no próprio governo e do conflito de atribuições entre os diversos órgãos que atuam na região, no conjunto, a tendência predominante foi a intensificação dos empreendimentos intensivos em capital na Amazônia. Estes empreendimentos, concentrando mais a renda e a propriedade, limitando as oportunidades de emprego e de acesso à terra, provocaram, consequentemente, intensos conflitos sociais na região ${ }^{339}$.
\end{abstract}

Para Magalhães, estes projetos foram os grandes instrumentos para a maior agressão, já conhecida, a um ecossistema. A abertura de estradas, a implantação de projetos de colonização, a fartura de terras baratas (no Acre, por exemplo, terras foram

\footnotetext{
${ }^{336}$ ZANNATA, Odair. Depoimento à Comissão Parlamentar de Inquérito destinada a investigar distorções ocorridas na execução dos Planos de Desenvolvimento da Amazônia. In: Diário do Congresso Nacional (Seção I), Suplemento ao no 156, Capital Federal, 05/10/80, p. 424 apud DUARTE, 1987, p. 43.

${ }^{337}$ CNBB-CEP. Pastoral da Terra - posse e conflitos. Estudos da CNBB-CEP, ed. $2^{\mathrm{a}}$. São Paulo: Edições Paulias, 1977, p. 90.

${ }^{338}$ DUARTE, 1987, p. 51.

${ }^{339}$ Id., p. 51.
} 
vendidas a Cr\$2,00 o hectare), financiamentos facilitados, atraíram aventureiros de todos os Estados. E o fracasso econômico das atividades extrativistas também contribuíram para atração de uma migração incontrolável ${ }^{340}$.

A seguir, podemos observar no gráfico 10, a taxa média de crescimento geométrico da população, na região Norte, entre 1950 a 1980.

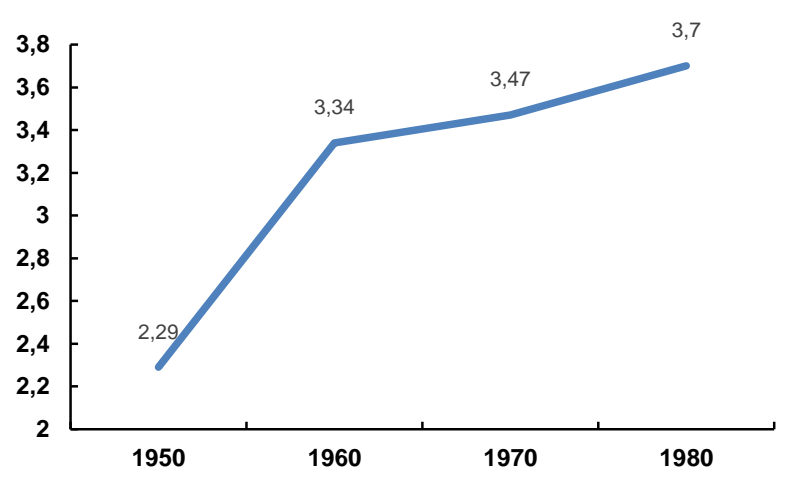

Gráfico 10 Taxa média geométrica de crescimento populacional na região Norte: 1950 a 1980

Fonte: Estatísticas do Século XX. Rio de Janeiro: IBGE, 2007. Disponível em http://seriesestatisticas.ibge.gov.br/. Acesso em: 31 dez. 2014.

Antes da Operação Amazônia, a região Norte possuía uma taxa média geométrica de 2,29 em seu crescimento populacional. Depois das políticas de ocupação, observamos que na década de 1960, este valor aumentou para 3,34 e, em 1980, já chegava em 3,7. Estes valores não corresponderam a um crescimento natural da própria região, mas esteve relacionado ao grande fluxo de migrantes que foram atraídos pela facilidade na obtenção de terras.

\subsubsection{Questionamentos sobre os resultados dos programas dos governos militares para a Amazônia}

Como vimos, a Operação Amazônia trouxe consigo um processo de destruição dos recursos naturais, especialmente das florestas. Podemos dizer que a destruição foi grande, semelhante à devastação da Mata Atlântica no período da colonização do país, bem retratada por Warren Dean ${ }^{341 .}$

340 MAgalhães, Juraci Perez. Recursos Naturais, Meio-Ambiente e sua Defesa no Direito Brasileiro. Rio de Janeiro: Ed. da Fundação Getulio Vargas: 1982, p. 32.

${ }^{341}$ DEAN, Warren. A Ferro e Fogo: a história e a devastação da Mata Atlântica brasileira. Tradução Cid Knipel Moreira; revisão técnica de José Augusto Drummond. São Paulo: Companhia das Letras, 1996. 
A literatura também tem chamado a atenção para como a Operação Amazônia privilegiou os grandes empresários. Para Duarte, grande parte das funções atribuídas aos órgãos encarregados pela Operação Amazônia, não foram implementadas, ficando somente no texto da Lei $^{342}$. E, para Ianni, tais órgãos tiveram como meta primordial apaziguar os latifúndios e empresários rurais, que formaram uma base econômica e política importante para o Golpe de Estado de 31 de março de 1964. Desta maneira, o próprio Estatuto da Terra ${ }^{343}$ adotado pelo governo de Marechal Castelo Branco (196467), resultou em um instrumento que indicava aos latifundiários e empresários rurais, qual seria a direção da política agrária a ser posta em prática pelos governos implantados em $1964^{344}$.

Na visão de Valverde, sob o pretexto de integrar a Amazônia à economia nacional, os governos militares construíram muitas estradas e foram instalando, ao longo delas, colonos que migravam. A colonização se deu principalmente em três faixas: na Transamazônica, entre Marabá e Itaituba (Pará); na Cuiabá-Porto Velho; e ao longo da Cuiabá-Santarém, na parte situada no Estado de Mato Grosso que, segundo o autor, estava entregue à colonização privada, e que nada mais fez senão especulação fundiária baseada em loteamentos ${ }^{345}$.

Ainda para Valverde, nem as companhias colonizadoras, nem os órgãos federais responsáveis pela reforma agrária, foram capazes de fixar totalmente os migrantes. Foram muitos os que abandonaram seus lotes e saíram para a periferia das cidades. Outros se internaram mais na selva, em busca de terras virgens.

Ao avaliar a região amazônica em seu processo de reorganização do espaço pelos militares, Schmink e Wood, argumentam que toda a estrutura organizada para atrair novos ocupantes e investimentos na região, resultou em mais de um bilhão de dólares de investimentos aprovados para a agropecuária, durante todo o período dos

\footnotetext{
342 DUARTE, 1987, p. 41.

${ }^{343} \mathrm{O}$ Estatuto das Terras regulou os direitos e obrigações concernentes aos bens imóveis rurais, para os fins de execução da Reforma Agrária e promoção da Política Agrícola. Ficou definido no Estatuto o conceitos de Reforma Agrária - conjunto de medidas que visem a promover melhor distribuição da terra, mediante modificações no regime de sua posse e uso, a fim de atender aos princípios de justiça social e ao aumento da produtividade -, e Política Agrícola - conjunto de providências de amparo à propriedade da terra, que se destinem a orientar, no interesse da economia rural, as atividades agropecuárias, seja no sentido de garantir-lhes o pleno emprego, seja no de harmonizá-las com o processo de industrialização dos país.(BRASIL. Lei n. 4.504, de 30 de novembro de 1964. Dispõe sobre o Estatuto da Terra e dá outras providências. Brasília: 1964).

344 IANNI, Octávio. Colonização e Contra-Reforma Agrária na Amazônia. Petrópolis: Ed. Vozes, 1979, p 37-38.

345 VALVERDE, Orlando. A Devastação da Floresta Amazônica. Revista Brasileira de Geografia. v. 3, n. 52. Rio de Janeiro: IBGE, julho/setembro, 1990, p. 11-24. p. 16.
} 
governos militares. Para os autores, os produtores de madeira industrial, juntamente com os fazendeiros, captaram a maior parte dos subsídios da SUDAM. Entretanto, o crédito para atividades tradicionais, como a extração da borracha, por exemplo, ficou em segundo plano ${ }^{346}$.

Como vimos, a SUDAM era responsável por avaliar os projetos para a região e, também, por fiscalizar sua implementação. Mas a falta de fiscalização levou ao desvio de recursos por meio de esquemas engenhosos que, segundo Schmink e Wood, contribuíram para um maior lucro das empresas, e não para o desenvolvimento da Amazônia. Algumas empresas usaram os subsídios da SUDAM para especular na bolsa de valores, outras reformulavam um mesmo projeto várias vezes e o enviavam novamente ao órgão para receber créditos adicionais ${ }^{347}$.

Na mineração não foi diferente, as companhias arrumaram formas criativas de driblar as restrições de suas operações. De acordo com Fernandes, apud Schmink, e Wood, "o limite de cinco autorizações por ano era fácil de burlar criando-se "empresas fantasmas", ou solicitando permissões para toda uma lista de substâncias diferentes ${ }^{\text {"348 }}$. Utilizando-se dessas formas ilegais, grandes áreas do sul do Pará foram monopolizadas por firmas, inclusive a estatal Companhia Vale do Rio Doce (CVRD), cujas 38 subsidiárias mantiveram 1.674 autorizações de pesquisa e 89 alvarás de $\operatorname{lavra}^{349}$.

Ainda segundo Valverde, o governo brasileiro, através do Ministério do Planejamento, declarou, em 1971, sua intenção de financiar apenas grandes unidades fundiárias que tivessem capacidade de trazer retornos fiscais e de gerar cerca de trinta mil empregos ou formar um rebanho de dois milhões de bovinos, tornando a Amazônia não apenas auto-suficiente, mas até exportadora de carne ${ }^{350}$.

\footnotetext{
Para atrair investidores, o governo brasileiro lhes concedeu isenção total de impostos durante dez anos e, mediante contrato aprovado pela SUDAM, o Banco do Brasil lhes assegurou, ademais, financiamentos a juros baixíssimos, em três parcelas: a primeira, destinada à derrubada, à queimada da floresta $\mathrm{e}$ ao plantio de pastos; a segunda, para a construção de benfeitorias, como casas, cercas, currais; e a terceira para formação do plantel $^{351}$.
}

\footnotetext{
346 SCHMINK, Marianne \& WOOD, Charles H. Conflitos Sociais e a Formação da Amazônia. Tradução de Noemi Miyasaka Porro e Raimundo Mourta. Belém: Ed. UFPA, 2012, p. 103.

${ }^{347}$ Id., p. 104.

${ }^{348}$ Ibid., p. 114.

${ }^{349}$ Ibid., p. 114.

${ }^{350}$ VALVERDE, 1990, p. 17.

${ }^{351} \mathrm{Id}$.
} 
Logo, grandes empresas transnacionais e nacionais foram atraídas: Volkswagen (automóveis), Atlântica-Boa Vista (banco e seguros, do grupo Rockefeller), Suiá-Missu (do grupo Liquifarma), SANBRA (norte-americana de óleos vegetais), VARIG-Cruzeiro (aviação comercial), Sul-América (seguros), Tamakavy (do grupo Sílvio Santos: rede de televisão e eletrodomésticos). Sem contar com o gigantesco Projeto Jari (celulose, mineração de caulim, agropecuária) de Daniel K. Ludwing, maior acionista da Universe Tank-ships e da National Bulk Carriers, com sede em Monróvia, que se apoderou de 3.600.000 hectares, na divisa do Pará com o Amapá ${ }^{352}$.

A literatura também tem chamado a atenção para o intenso desmatamento que acompanhou estes empreendimentos. Valverde lembra que o Senador Jarbas Passarinho, relator da Comissão Parlamentar de Inquérito, instaurada pelo Senado Federal em 1989, afirmou que os projetos agropecuários implantados na Amazônia não tinham nada de “agro" sendo, na verdade, responsáveis pelo desmatamento, em grande escala, da hiléia amazônica ${ }^{353}$. E Magalhães ressaltou que, “... muitos recursos foram desviados sem que projetos fossem executados, deixando apenas a marca da agressão ao meio-ambiente com a transformação da floresta em capoeira" ${ }^{354}$.

Na opinião de Valverde, além dos danos causados à natureza, os projetos agropecuários, tiveram de apelar para o tráfico de mão-de-obra, pois foram instalados, quase todos, em lugares distantes e pouco acessíveis. Então, foram encarregados empreiteiros, conhecidos como "gatos", que atraíam trabalhadores rurais sem-terra, ingênuos e ignorantes, para se transferirem para os projetos, com promessas de bons salários e benefícios sociais. Em alguns lugares, os trabalhadores rurais da região se reuniram em sindicatos, procurando resistir como posseiros ou fazendo valer seus direitos, apoiados por padres da Comissão Pastoral da Terra (CPT), advogados trabalhistas e políticos de esquerda ${ }^{355}$.

Em contrapartida, os latifundiários também se organizavam, na chamada União Democrática Ruralista (UDR), com a qual promoviam leilões de gado, apurando fundos para a compra de armas de guerra (geralmente no Paraguai) e a contratação de

\footnotetext{
${ }^{352}$ Em consequência das pressões de políticos e da opinião pública, o Projeto Jarí passou em 1983 por aparente nacionalização, sendo vendido a 23 empresas nacionais, mas controlada por um sócio de Lucwig, o Sr. A. T. Azevedo Antunes, que detinha 40\% das ações (VALVERDE, 1990, p. 17).

${ }^{353}$ VALVERDE, 1990, p. 17.

${ }^{354}$ MAGALHÃES, 1982, p.31.

${ }^{355}$ VALVERDE, 1990, p. 17-18.
} 
pistoleiros, usados no assassinato de líderes rurais, bem como de padres, advogados e políticos que os apoiassem ${ }^{356}$.

Valverde, em seu artigo de 1990, sobre a devastação da floresta amazônica, também chama a atenção para outra atividade de grande impacto: a extração de madeira. Antes da década de 1970, já existiam pelo menos três grandes madeireiras multinacionais funcionando na Amazônia: a Georgia Pacific (norte-america), a Toyomenka (japonesa) e a BRUMASA, subsidiária da firma holandesa Bruynzeel. Em seu texto, o autor alertava, ainda, para o crescimento do desflorestamento na região baseado em fins lucrativos rápidos. Inclusive citava que o maior importador de madeiras tropicais, naquele momento, era o Japão e que seus cartéis estavam consolidados num bloco denominado International Tropical Timber Organisation (ITTO). Esse bloco havia feito, em 1987, um contrato com o governo do Acre, propondo asfaltar por sua conta a rodovia Rio Branco-Cruzeiro do Sul (BR-364) e completá-la até Pucallpa, no Peru, centro petrolífero de onde era possível alcançar a costa do Pacífico por rodovias pavimentadas. Desta forma, o acesso ao mercado japonês ficaria bem curto e mais barato $^{357}$. Hoje a estrada já é uma realidade ${ }^{358}$.

Como vemos, a literatura que se voltou para as políticas implementadas pelos governos militares na Amazônia, nos anos 1970 e 1980, tem chamado a atenção para a forma como foi privilegiado o incentivo financeiro e tributário aos grandes empreendimentos, e como a questão da reforma agrária ficou em segundo plano. Também tem destacado a intensa destruição por que passou a floresta amazônica no período.

\subsection{A (Re)Ocupação da Região Acreana nos anos 1970-1980}

\subsubsection{Localização Geográfica do Estado do Acre}

O Estado do Acre localiza-se no extremo sudoeste da Amazônia brasileira, entre as latitudes de $07^{\circ} 07^{\prime} \mathrm{S}$ e $11^{\circ} 08^{\prime} \mathrm{S}$, e as longitudes de $66^{\circ} 30^{\prime} \mathrm{W}$ e $74^{\circ} \mathrm{WGr}$. Atualmente

\footnotetext{
356 VALVERDE, 1990, p. 18.

${ }^{357}$ Id., p. 18-19.

358 Atualmente denominada Estrada do Pacífico, liga o Brasil ao Peru. Ela passa pelo Estado do Acre, através BR-317, chegando a Iñapara no Peru, depois se divide inicialmente em duas direções: Oeste (Rodovia PE-036, passando por Nazca, Cuzco até o Porto San Juan de Marcona) e Sul (nesta rota a estrada se subdivide em duas direções na região próximo ao Lago Titicaca: segue pela PE-034 até o Porto de Matarani e pela PE-036 até o Porto de Ilo).
} 
ocupa uma superfície territorial de $164.221,36 \mathrm{~km}^{2}$, englobando $4 \%$ da área da Amazônia brasileira e $1,9 \%$ do país. Conta com vinte e dois municípios e tem como capital a cidade de Rio Branco. Sua população é composta de 776.463 habitantes ${ }^{359}$, com densidade demográfica da ordem 4,47 hab/ $\mathrm{Km}^{2}$. O Estado faz fronteira internacional com o Peru e Bolívia, e nacionais com os estados do Amazonas e Rondônia.

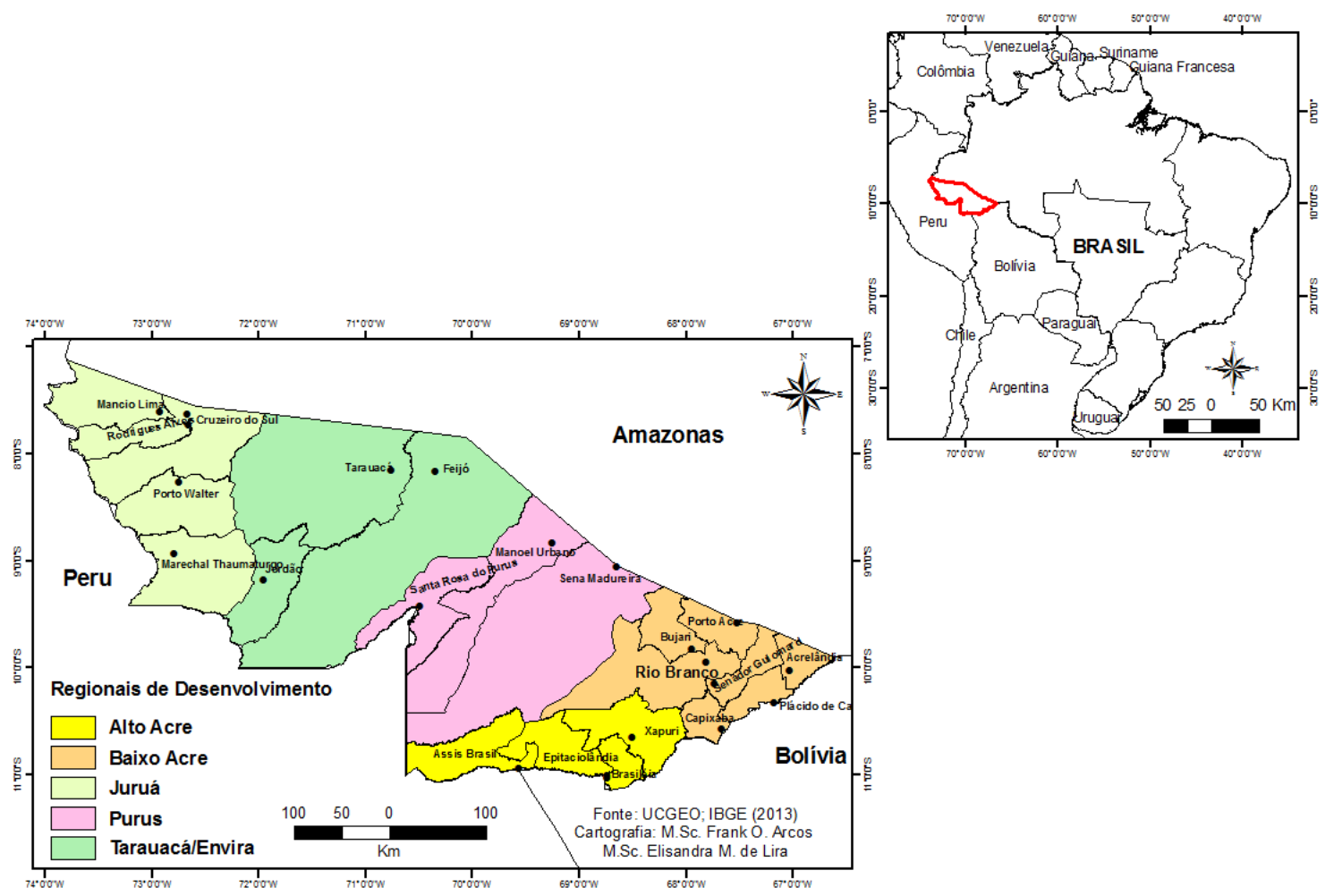

Mapa 2 Localização Geográfica do Estado do Acre - Regionais de Desenvolvimento.

O Estado está dividido em cinco microrregiões, estabelecidas pelo Instituto Brasileiro de Geografia e Estatística (IBGE), que seguem a distribuição das bacias hidrográficas dos principais rios. No ano de 2000, com a publicação do Zoneamento Ecológico e Econômico do Estado, as microrregiões foram definidas como Regionais de Desenvolvimento ${ }^{360}$.

\footnotetext{
359 População estimada para 2013. IBGE. Instituto Brasileiro de Geografia e Estatística. Estados. Disponível em: <http://www.ibge.gov.br/estadosat/perfil.php?sigla=ac> Acesso em: 06/12/2013.

360 ACRE. Governo do Estado do Acre. Programa Estadual de Zoneamento Ecológico-Econômico do Estado do Acre. Zoneamento ecológico-econômico: aspectos socioeconômicos e ocupação territorial documento final. v.2, Primeira Fase. Rio Branco: SECTMA, 2000, p. 11.
} 


\subsubsection{Nova onda de ocupação do território acreano pelos "Paulistas"}

O período militar se instalou no território acreano com o governo do capitão do Exército Edgard Pedreira de Cerqueira Filho, que atuou no período de 8 de maio de 1964 a 14 de agosto de 1966. Depois de dois anos de governo, as eleições indiretas para governadores passaram a vigorar em todo o território brasileiro. No Acre, Jorge Kalume assumiu o governo, pelo partido de sustentação à ditadura militar, Aliança Renovadora Nacional (ARENA), pelo período de 13 de setembro de 1966 a 15 de março de 1971. Após o mandato de Kalume, assumiram Francisco Wanderley Dantas (1971-1975), Geraldo Gurgel de Mesquita (1975-1979) e Joaquim Falcão de Macedo (1979-1983) ${ }^{361}$.

Durante este período, o Estado foi marcado por um cenário de violência, que veio no bojo da então recente ocupação das áreas de fronteira pela frente de expansão agropastoril, como vimos, a chamada "Operação Amazônia". Segundo Costa Sobrinho, como as atividades econômicas tradicionais da região não foram incluídas nos programas governamentais, "no caso do Acre, o velho extrativismo gomífero e da castanha estavam fadados ao desaparecimento "362.

Realmente foi o que aconteceu, as políticas de ocupação para a região amazônica no período militar, desencadearam um processo de reorganização do espaço e uso da terra. A estratégia dos governos militares para integração da região Amazônica ao restante do país, motivou a chegada de inúmeros migrantes oriundos da região sudeste do país, denominados "paulistas" 363, que foram à procura de terras fartas e de baixos preços. Os empresários foram atraídos pelos incentivos fiscais oferecidos pelo governo federal, sem contar com a vinda de pequenos colonos, motivados pelos projetos de colonização do INCRA, que dava incentivo às atividades agropecuárias.

A princípio, os projetos agropecuários aprovados pela SUDAM se estabeleceram no Mato Grosso, Goiás e Pará, pois eram áreas mais próximas às regiões que tinham maior densidade demográfica. Dos anos 1960 até agosto de 1980, dos 326 projetos agropecuários aprovados pela SUDAM, 91,72\% se encontravam nos Estados supracitados, e o restante, $8,28 \%$, foram estabelecidos nas outras unidades federativas

361 DANTAS, Juliana de Souza. Estado e Sociedade Civil no Acre (1970-1980). 113f. Dissertação (Mestrado em Ciências Sociais). Natal: Universidade Federal do Rio Grande do Norte, Centro de Ciências Humanas, Letras e Artes, Programa de Pós-Graduação em Ciências Sociais, 2008, p. 58.

${ }^{362}$ COSTA SOBRINHO, Pedro Vicente. Meios Alternativos de Comunicação e Movimentos Sociais na Amazônia Ocidental (Acre: 1971-81). 228f. Tese (Doutorado em Ciências da Comunicação). São Paulo: Programa de Pós-Graduação da Escola de Comunicação e Artes da Universidade de São PauloUSP, 2000. p. 10-11

${ }^{363}$ Denominação dada aos novos migrantes que vinham do Sul do país em busca de terras fartas e baratas. 
pertencentes à Amazônia Legal (Acre, Amapá, Amazonas, parte do Maranhão, Rondônia e Roraima) ${ }^{364}$.

De acordo com Duarte, no Acre a dificuldade da SUDAM em aprovar mais projetos se deu pela situação jurídica confusa das terras:

[...] Com a exigência da SUDAM, a partir de 1976, de provas de regularização jurídica da área e com a morosidade do INCRA em regularizar as terras do Acre, a aprovação de projetos ficou bastante limitada. Mas, os compradores de terra mantinham a esperança de regularizar rapidamente a situação fundiária do Estado, a fim de que eles pudessem usufruir dos incentivos oferecidos ${ }^{365}$.

Para contextualizar o processo de reorganização do espaço acreano, resultante das estratégias militares de ocupação para a região, nosso período de referência ficou concentrado no governo de Francisco Wanderley Dantas ${ }^{366}$, pois foi neste governo que o processo foi intensivo.

No período de 15 de março de 1971 a 30 de setembro de 1972, Dantas sancionou 44 leis, que revelaram suas várias intenções para o "desenvolvimento do Estado". Dentre os assuntos elencados em suas leis podemos destacar: a abertura de créditos especiais, aquisição de terras urbanas, constituição da Companhia de Saneamento do Estado do Acre S/A - SANACRE, autorização de crédito especial para o sistema educacional (por meio audiovisual), autorização para o Poder Executivo adquirir áreas de seringais, alienar terras públicas do Estado para efeito de colonização e aproveitamento agrário, dentre outros ${ }^{367}$.

No relatório de atividades do seu governo, Dantas defende a diversificação das atividades econômicas, pois as atividades extrativistas, já praticadas, não ofereciam

\footnotetext{
${ }^{364}$ Informações dadas no depoimento do Dr. Hugo de Oliveira Rocha, Procurador Geral da SUDAM, à Comissão Parlamentar de Inquérito destinada a investigar distorções na execução do Plano de Desenvolvimento da Amazônia (CPI da Amazônia), realizada em 5 de dezembro de 1980 pelo Congresso Nacional. Apud DUARTE, 1987, p. 55.

${ }^{365}$ DUARTE, 1987, p.55.

${ }^{366}$ Francisco Wanderley Dantas era filho do Coronel Sebastião Gomes Dantas e de dona Maria Cândida e nasceu na Vila Porto Acre, Estado do Acre, no dia 22 de outubro de 1932. Estudou no Rio de Janeiro, onde se formou em Filosofia. Em 1959 tomou parte na Campanha para a transformação do Acre em Estado, formando com os seus companheiros do Comitê Pró-Autonomia do Acre, uma bandeira em favor da emancipação política. Com a transformação do Acre em Estado, em 1962, Dantas candidatou-se a Deputado Federal, e em 1963, como primeiro suplente, assumiu a vaga do Deputado Valério Magalhães (devido ao seu falecimento). Como parlamentar acreano, assumiu duas legislaturas de 63 a 70 . E, em 15 de março de 1971, foi escolhido pelo Presidente Médici, para dirigir o então mais novo Estado da Federação (GOVERNO DO ESTADO DO ACRE. Novo Acre, Um Estado em Ação: agora também a independência econômica do Acre. Notícias - Informações. Ano I, nº X. Rio Branco-AC: de 1 a 31 de outubro de 1972 ?.

${ }^{367}$ Id.
} 
grandes perspectivas. Para tanto, o governo apresentou vários projetos que seriam financiados com os recursos provenientes do Programa de Redistribuição de Terras e de Estímulo à Agro-indústria do Norte e Nordeste (PROTERRA). Dentre os projetos agroindustriais merecem destaque:

1) A construção de uma Usina de Pasteurização de Leite em Rio Branco, tendo em vista haver mercado consumidor para o produto e seus subprodutos;

2) Implantação de usinas de lavagem de borracha nos municípios de Cruzeiro o Sul, Tarauacá e Xapuri, com objetivo de estimular a organização de grupos de produtores (seringalistas) sob a forma de sociedade anônimas e/ou sociedades cooperativas;

3) Implantação de indústria de beneficiamento de castanha em Xapuri para atender a demanda das áreas de grande produção; $; 68$

4) Projetos agropastoris, que tratavam de culturas de arroz e feijão, desenvolvimento da fruticultura, avicultura, bovinocultura, comercialização, suinocultura e pimenta do reino ${ }^{369}$.

Após 2 anos do governo de Dantas, o relatório de atividades de seu governo, intitulado "Ano de Impacto e das Grandes Metas - A Borracha, Fator de Ocupação do Acre, Futuro Promissor dos Investidores", anunciava, dentre outras benfeitorias: inauguração de um escritório da Empresa Brasileira de Telecomunicações (EMBRATEL); reorganização e implantação de novos equipamentos para o setor de rádio-comunicações; inauguração do Fórum "Barão do Rio Branco" para o funcionamento da parte burocrática dos serviços afeitos à Justiça; construção de um Hospital de Clínicas; conclusão da pista do aeroporto Internacional de Rio Branco e asfaltamento do acesso aeroporto - centro da cidade (extensão de $2 \mathrm{~km}$ ); inauguração do Círculo Militar, que objetivava a "congregação de civis e militares, para fins de lazer e confraternização"; entrega de casas às vítimas das enchentes do Rio Acre; entrega de unidade geradora de energia elétrica em Vila Plácido de Castro, fronteira com Bolívia; e a instalação da primeira unidade de tratamento de água de Rio Branco $^{370}$.

Em exposição proferida em abril de 1973, no I Seminário de Integração Nacional (promovido pela Associação Brasileira de Banco de Desenvolvimento e Jornal do Brasil), realizado no Hotel Glória, no Estado da Guanabara ${ }^{371}$, o governador Dantas fez vários apelos ao empresariado do Centro-Sul do país, utilizando como argumento os

\footnotetext{
${ }^{368}$ O Estado do Acre era considerado o terceiro produtor de castanha-do-pará do país. Nesse período já se encontrava em fase de finalização a primeira indústria de beneficiamento primário na Capital.

${ }^{369}$ GOVERNO DO ESTADO DO ACRE. Novo Acre. Notícias - Informações. Ano II, $\mathrm{n}^{\circ}$ 17. Rio Branco-AC: junho/julho de 1973c? p. 4.

${ }^{370}$ GOVERNO DO ESTADO DO ACRE. Novo Acre, Ano do Impacto e das Grandes Metas - "A Borracha, Fator de Ocupação do Acre, Futuro Promissor dos Investidores". Notícias - Informações Ano II, $\mathrm{n}^{\circ}$ 14. Rio Branco-AC: fevereiro de1973a? p. 5-18.

${ }^{371}$ GOVERNO DO ESTADO DO ACRE. Novo Acre, O Desafio da Integração e do Desenvolvimento Produzir no Acre, Investir no Acre, Exportar pelo Pacífico. Notícias - Informações. Ano II, $n^{\circ} 15$. Rio Branco-AC: abril de 1973b? p. 3-4.
} 
incentivos fiscais para o desenvolvimento da Amazônia Ocidental, estabelecidos pelo Decreto-lei n 291 de 28 de fevereiro de $1967^{372}$, e ainda a adoção da agropecuária como atividade econômica básica a ser desenvolvida. Estes foram os dois principais argumentos utilizados por Dantas, na política que abriu as portas do Acre, durante o Seminário, onde estiveram presentes autoridades, técnicos e investidores nacionais e internacionais.

Dantas incentivou, através de intensa campanha publicitária, a corrida pelas terras do Acre, divulgando as potencialidades das terras, facilidades de aquisição e as vantagens de se investir nesta região. "Investir no Acre, produzir no Acre, exportar pelo Pacífico" era o "slogan" 373 da sua campanha, que teve resposta imediata. Segundo Duarte, ao término de seu mandato, o governador Dantas já havia vendido pelo menos um terço das terras do Acre aos $\operatorname{sulistas}^{374}$. Foi neste período que a corrida pela incorporação das áreas de florestas, através da ocupação das terras acreanas pela nova frente agropastoril, tomou forte impulso ${ }^{375}$.

Neste processo, os recursos florestais sofreram grande impacto, pois eram alvo de exploração dos novos empreendimentos:

$\mathrm{Na}$ exploração dos recursos naturais, encontramos a madeira de lei como atividade de alta rentabilidade, dadas as suas concentrações favoráveis, o relativamente baixo custo das terras, no momento, e a crescente demanda do mercado, principalmente com a exaustão das florestas dos tradicionais centros produtores nacionais e internacionais. ${ }^{376}$

O Governo pregava ainda que ao investir no Acre, principalmente no ramo de transformação industrial, os empresários estariam cobertos por um vasto mecanismo de incentivos fiscais, o que beneficiaria o investidor com menores inversões, menor capital de giro, possibilitando consequentemente maior rentabilidade.

O vasto mecanismo de incentivos fiscais, o baixo custo de transporte até os portos do Pacífico, em virtude da pequena distância que separa o Estado e aquele oceano, um mercado externo nele situado de alto poder aquisitivo e

\footnotetext{
372 BRASIL. Decreto-lei $\mathbf{n}^{\mathbf{0}}$ 291, de 28 de fevereiro de 1967. Estabelece incentivos para o desenvolvimento da Amazônia Ocidental da Faixa de Fronteiras abrangida pela Amazônia e dá outras providências. Brasília: 1967.

${ }^{373}$ Para Dantas quando o Brasil se tornasse um País de dois oceanos, pelas ligações ao Pacífico, o Acre se beneficiaria de sua estratégica posição geográfica, constituindo-se no Estado mais promissor da Amazônia para a área de investimentos privados e, segundo suas previsões técnicas, a ligação seria feita a curto prazo (GOVERNO DO ESTADO DO ACRE, 1973b? p. 3).

${ }^{374}$ DUARTE, 1987, p. 56.

${ }^{375}$ COSTA SOBRINO, 2000, p. 33.

${ }^{376}$ GOVERNO DO ESTADO DO ACRE, 1973b? p. 4
} 
em crescente demanda de produtos que encontram em nosso território as melhores condições para a sua obtenção; uma demanda nacional ascendente, tudo isto constitui indicadores que colocam o Acre em privilegiada situação de apoio aos projetos empresariais ${ }^{377}$.

Em seu discurso sobre as oportunidades de investimentos e a recepção do governo para os investidores em potencial, Dantas deixa clara sua intenção de ocupar a região por meio da inserção da indústria de processamento, extração de madeira e pecuária. Empreendimentos que, segundo ele, mudariam totalmente a paisagem do Estado e as condições sociais, especialmente daqueles que não tinham recursos para investir, como os seringueiros, índios e posseiros.

No Rio de Janeiro e em São Paulo, as propagandas oficiais anunciavam a região acreana como "um sul sem geadas, um nordeste sem seca" e, mais tarde, "o filé mignon da Amazônia", e foram muitos os empresários que apostaram no novo eldorado amazônico, investindo o seu capital, e arrastando, também, uma porção de grileiros e especuladores. Tais medidas, trouxeram mudanças repentinas para as populações que tradicionalmente viviam nas florestas: índios, seringueiros, ribeirinhos e colonos. Estes tiveram suas terras invadidas e devastadas, em favor de um novo tipo de progresso que trazia consigo uma grande destruição dos recursos florestais ${ }^{378}$.

Só no mandato de Dantas, foram vendidos 4.290.930 hectares de seringais para 284 proprietários de fora, sendo que $32 \%$ dessa área foi adquirida por apenas quatro proprietários $^{379}$. Dando início a uma grande concentração fundiária na região.

Devido as mudanças traçadas pelo governo federal em relação à ocupação econômica da região amazônica, vimos que os Bancos deixaram de financiar os seringalistas e passaram a exercer, com exclusividade, as operações de compra e venda da borracha. Os seringalistas por sua vez, se viram sem condições de continuar aviando $^{380}$ os seringueiros, e não conseguiram mais juntar a quantidade de borracha necessária para pagar os débitos no Banco. Segundo Duarte, sem produzir e sem

\footnotetext{
377 Id., p. 8.

${ }^{378}$ MINISTÉRIO DO MEIO AMBIENTE. Cadernos Povos da Floresta. Rio Branco: Comitê Chico Mendes, 2003. 112p. p. 19.

379 Depoimento do ex-governador Geraldo Mesquita, na Comissão de Agricultura da Câmara dos Deputados apud ISABEL, Rosa Maria Roldan Santana. Acre: das lutas socioambientais ao desafio de um desenvolvimento sustentável. 117f. Dissertação (Mestrado em Desenvolvimento, Agricultura e Sociedade). Seropédica-RJ: Universidade Federal Rural do Rio de Janeiro, 2001. p. 20.

${ }^{380}$ Fornecer mercadoria a alguém em troca de outro produto. Era o que acontecia na relação de trabalho entre o seringalista e o seringueiro.
} 
condições de saldar as dívidas com o Banco, os donos dos seringais foram obrigados a vender suas terras a preços baixíssimos ${ }^{381}$.

Padre Paulino, um dos maiores conhecedores dos seringais do Acre, em entrevista concedida ao jornal Varadouro em 1979, referiu-se exatamente a este novo contexto de endividamento dos seringalistas:

[...] devido à instabilidade do mercado, a maioria dos seringalistas endividouse com o BASA, que passou a cobrar de seus clientes juros sobre juros de suas enormes dívidas. Os seringalistas não conseguiram aguentar o rojão e o BASA foi forçado a vender os seringais a fim de que eles pudessem pagar suas dívidas. Os seringalistas passaram a ser escravos do BASA e os seringueiros escravos de seus patrões. Nessa crise, os seringueiros começaram a procurar as cidades mais próximas, mas ainda não era um êxodo em massa, como ocorreu posteriormente, no início das vendas das terras para o especuladores, grileiros e investidores do sul. De 1970 em diante foi que se começou a falar de paulistas e da venda dos seringais. Não havendo quem avie mercadorias, os seringueiros logo fogem, vão procurar outro meio de vida ${ }^{382}$.

Em entrevista concedida ao Jornal da Tarde (setembro de 1988), na colocação

Fazendinha, Seringal Cachoeira, o seringueiro e sindicalista Chico Mendes fez o seguinte relato sobre a falência dos seringais e o novo modelo de ocupação e uso da terra no Acre:

(...) em 64, com o golpe militar, o Castelo Branco acaba com o monopólio estatal da borracha e o Banco fecha as suas portas. O monopólio, quer dizer, era o monopólio que garantia todo o domínio dos patrões, dos seringalistas. Só podia vender pro Banco. O patrão era submetido, nós éramos escravos dos patrões, submetidos a ele, e eles eram submetidos às ordens do Banco. Então ele tinha que fazer aquilo que o Banco mandava. Acontece que quando o Castelo Branco acaba com o monopólio da borracha e fecha o Banco da Borracha, aí esses caras entraram em falência, bancaram a falência. E aí, até aí os seringueiros ainda pagavam renda. Aproveitando-se desse momento, existem vários movimentos para não pagamento de renda. Mas muito fracos. Aí o que eles fazem. Aí então que começa a mudança radical, a estrutura violenta, porque aí o governo... em 69, em 70, o governo do Acre vai no sul do país, e faz aquele alarme, propaganda, o Acre tem terra farta e barata e os acreanos são malandros, nós precisamos do progresso. E aí vem a correria dos fazendeiros do sul e com apoio dos incentivos fiscais da SUDAM, de 70 até 75, compraram 6 milhões de hectares de terra aqui nessa região, no Estado do Acre ${ }^{383}$.

${ }^{381}$ DUARTE, 1987, p. 57; ISABEL, 2001. p. 21.

${ }^{382}$ Jornal Varadouro N.15, junho de 1979, p. 12 apud ALLEGRETTI, Mary Helena. A Construção Social de Políticas Ambientais - Chico Mendes e o Movimento dos Seringueiros. 827f. Tese (Doutorado em Desenvolvimento Sustentável - Gestão e Política Ambiental). Brasília-DF: Universidade de Brasília, Centro de Desenvolvimento Sustentável, 2002. p. 210-211.

${ }^{383}$ ALLEGRETTI, 2002, p. 125. 
O governo do Acre ofereceu ainda, serviços dos órgãos estatais para elaboração de projetos agropastoris e estrutura de apoio à implantação dos projetos na região. Através do Banco do Estado do Acre (BANACRE), que disponibilizava recursos financeiros para os empreendedores, além dos já oferecidos pelo Banco do Brasil e BASA, que ofereciam juros baixos a longo prazo de carência e pagamento. Para Duarte, com tantos estímulos aos empresários, não só pequenos e médios fazendeiros adquiriram terras no Acre, mas, principalmente, os especuladores de terra e grandes grupos econômicos ${ }^{384}$.

Tabela 12 Estabelecimentos Agropecuários (por número e área) no Acre: 1970, 1975 e 1980

\begin{tabular}{|c|c|c|c|c|c|c|}
\hline \multirow[t]{2}{*}{$\begin{array}{l}\text { Grupo de Área Total } \\
\text { (ha) }\end{array}$} & \multicolumn{3}{|c|}{$\begin{array}{c}\text { Número de } \\
\text { Estabelecimentos } \\
\text { (Unidade) }\end{array}$} & \multicolumn{3}{|c|}{$\begin{array}{c}\text { Área do } \\
\text { Estabelecimento } \\
\text { (Hectares) }\end{array}$} \\
\hline & 1970 & 1975 & 1980 & 1970 & 1975 & 1980 \\
\hline Menos de 10 & 2.189 & 3.340 & 2.768 & 9.610 & 10.794 & 11.423 \\
\hline 10 a menos de 100 & 7.193 & 7.409 & 10.845 & 248.844 & 297.737 & 449.813 \\
\hline 100 a menos de 1000 & 13.528 & 14.014 & 13.445 & 2.654 .323 & 2.724 .262 & 3.292 .411 \\
\hline 1000 a mais & 192 & 119 & 313 & 1.212 .308 & 1.258 .984 & 1.925 .880 \\
\hline Total & 23.102 & 25.001 & 27.371 & 4.122.084 & 4.291.777 & 5.679 .532 \\
\hline
\end{tabular}

Segundo a tabela do IBGE no ano de 1970 o número de estabelecimentos agropecuários era de 23.102, o correspondente a 4.122.084ha das terras acreanas $\left(41.220,84 \mathrm{~km}^{2}\right)$. Neste período, destacaram-se as propriedades que tinham de $100 \mathrm{a}$ menos de 1000ha, com 13.528 estabelecimentos, cobrindo uma área de 2.654.323ha $\left(26.543,23 \mathrm{~km}^{2}\right)$, representando quase $65 \%$ da área total de estabelecimentos agropecuários registrados. Em segundo lugar, destacaram-se os estabelecimentos com área igual e/ou superior a 1000 ha, cobrindo uma superfície de 1.212.308ha (12.589,84 $\mathrm{km}^{2}$ ), quase $30 \%$ da área total de estabelecimentos. Juntos, esses dois grupos de áreas cobriam cerca de $95 \%$ do total de áreas registradas.

Esta situação nos mostra que as estratégias do governo federal, através dos vários tipos de incentivos à ocupação da Amazônia, estimularam a especulação fundiária e a formação de grandes latifúndios. Em dezembro de 1976, o diretor do Instituto de Pesquisas da Amazônia (INPA), Warwick Kerr, mostrou preocupação com o problema do desflorestamento no Acre, informando que o ritmo acelerado da destruição

${ }^{384}$ DUARTE, 1987, p.56-57. 
das florestas levaria a total inexistência da mesma em apenas 33 anos. Segundo ele, em 1974 os desmatamentos eram inferiores a 1\% de toda a área florestal; em 1975, a porcentagem quase dobrou (1,8\%); e em 1976 o valor subiu para 3,5\%, ou seja, três vezes mais em apenas dois $\operatorname{anos}^{385}$.

Em 1975, no último ano do governo de Dantas, os jornais anunciavam que um dos maiores problemas que o Acre estava sofrendo era a grilagem organizada ${ }^{386}$. O Presidente do INCRA, Lourenço Vieira da Silva, em exposição proferida na Comissão Amazônia, na Câmara dos Deputados, em 1975, declarou que as atividades do órgão eram problemáticas tendo em vista a grilagem de terras que estava acontecendo, principalmente no Acre ${ }^{387}$.

Grandes grupos se envolveram na grilagem de terras no Acre, o jornal O Estado de São Paulo, em uma reportagem com o tema "Um roteiro das grandes grilagens", destacou que:

[...] A Cia de Desenvolvimento Novo-Oeste, sob a direção do General Bandeira de Melo (ex-Presidente da FUNAI), adquiriu, dos herdeiros de um seringalista acreano, oito glebas que formavam o Seringal Califórnia, de 624.200 ha. Obteve, em seguida, financiamentos do BASA e da SUDAM. Mas no inventário do seringalista constavam apenas 8.117 ha. Após descobertas as irregularidades, os financiamentos foram sustados. Também o Seringal Rio Novo, de 17.697 ha., que foi transformado em Cia. AgroIndustrial Rio Novo (Banco Real) com 64.069 ha $^{388}$.

No início da década de 1980 a Polícia Federal em Rio Branco, tinha instaurado doze inquéritos sobre grilagens, na sua maioria sobre falsificação de títulos, como foi o caso dos seringais Catuaba, Bagaço e Monte Alegre, que tinha como suspeito Cesar Claure Vasques, que possuía títulos emitidos pelo país vizinho, Bolívia. A maioria dos inquéritos tratavam de irregularidades de títulos, com ênfase nos famosos esticamentos, ou seja, acréscimo de grandes áreas de terras às já obtidas ${ }^{389}$.

\footnotetext{
${ }^{385}$ VARADOURO. Rio Branco, ano I, no 1, maio de 1977, p. 5 apud COSTA SOBRINHO, p. 148.

386 É o termo usado para a apropriação ilícita de terras por meio da expulsão de seus proprietários, posseiros ou índios. Também denomina a legalização do domínio da terra através de documento falso. Esse termo, grilagem, é utilizado, pois em outras épocas se fazia uso de grilos, colocados em gavetas sobre papéis que precisavam parecer velhos para dar "autenticidade" a títulos de terras. Os papéis adquiriam características com cor amarelada e pequenas corrosões (Relatório da Comissão Parlamentar de Inquérito destinada a investigar a Ocupação de Terras Públicas na região amazônica. Brasília: 2001, p. 348).

387 O Estado de São Paulo, INCRA denuncia grilagem no Acre, São Paulo, 30/04/75 apud DUARTE, 1987, p. 62.

388 O Estado de São Paulo, Um roteiro das grandes grilagens. São Paulo, 15/04/79, p. 22 apud DUARTE, 1987, p. 62.

${ }^{389}$ O Rio Branco, Escândalo: 600 km de terras foram griladas no Acre. Rio Branco, 06/05/81, p. 12 apud DUARTE, 1987, p. 62-3.
} 
Segundo Duarte, a maioria das terras acreanas "foram vendidas de maneira irregular e caíram nas mãos de grandes grupos econômicos, causando prejuízos de diversas ordens no Estado. ${ }^{390}$ Neste contexto, podemos citar a expulsão de um grande número de famílias de seringueiros que dependiam da floresta para a sua subsistência, e os que permaneceram, passaram para a condição de posseiros, considerados indesejáveis aos seringalistas que pretendiam vender suas terras aos "novos donos", que não tinham interesse pelo extrativismo. Neste sentido, segundo Oliveira, a presença da população continuava a ser um obstáculo no processo de transferência da propriedade, a partir do momento em que se iniciava o processo de regularização jurídica das propriedades $^{391}$.

Os anos se passaram e a concentração de terras na região só aumentou. Para termos uma ideia mais concreta da situação fundiária no Acre, apresentamos a seguir uma tabela, com a relação dos doze maiores proprietários de terras até maio de 1980.

Tabela 13 Relação das maiores propriedades rurais no Acre em 1980

\begin{tabular}{llr}
\hline \multicolumn{1}{c}{ MUNICÍPIO } & \multicolumn{1}{c}{ PROPRIETÁRIO } & ÁREA (HA) \\
\hline Sena Madureira & Coloama - Colonizadora Agropecuária São Paulo- & $1.000 .000,00$ \\
& Amazonas S.A. & \\
Sena Madureira & Nelson Taveira - Seringal Vale do Rio Chandless & $975.000,00$ \\
Tarauacá & Paranacre & $600.000,00$ \\
Feijó & Companhia de Desenvolvimento Novo Oeste & $510.000,00$ \\
Sena Madureira e Rio & José Mario Junqueira, Ismerindo Ribeiro do Vale, Líbero & $440.000,00$ \\
Branco & Luchesi e outros. & \\
Feijó & Fazenda Califórnia & $427.000,00$ \\
Cruzeiro do Sul & Santana Empreendimento Agropastoril & $350.000,00$ \\
Tarauacá & Condomínio Tarauacá & $300.000,00$ \\
Sena Madureira & Coapai - Cooperativa Agropecuária Alto Iaco Seringal & $187.000,00$ \\
& Icuriã & \\
Tarauacá & Agronorte & $160.000,00$ \\
Rio Branco & Rômulo Bonalumez (na divisa do Acre com Amazonas) & $152.000,00$ \\
Tarauacá & Agropastoril Leal Ind. Com. Ltda. & $114.000,00$ \\
TOTAL & & $\mathbf{5 . 2 1 5 . 0 0 0 , 0 0}$ \\
\hline
\end{tabular}

Fonte: Jornal Varadouro N. 19, maio de 1980 apud ALLEGRETTI, 2002, p. 212-213.

De acordo com a tabela, em 1980 os doze maiores proprietários detinham cerca de $34,18 \%$ de toda a área de terras do Acre (a área territorial do Acre era de 152.589,00 $\mathrm{km}^{2}$ ). Vale salientar que nesta lista podemos constatar a presença de grandes grupos empresariais que tinham suas propriedades ao longo da BR-364, em direção a Cruzeiro

\footnotetext{
${ }^{390}$ DUARTE, 1987, p. 63.

391 OLIVEIRA, Fernando Garcia de. População de Baixa Renda da Cidade de Rio Branco: situação anterior, processo migratório, formas de inserção/retribuição no mercado de trabalho. 232f. Dissertação (Planejamento Urbano e Regional). Rio de Janeiro: UFRJ: 1978, p. 87.
} 
do Sul, região mais ocidental do Estado (na época, sem pavimentação asfáltica, em péssimas condições de trafegabilidade), indicando claramente que, mais importava o título de propriedade, que a propriedade com base para atividade produtiva. A falta de condições de acesso, também constituía fator de desvalorização. As terras eram adquiridas como títulos que permitiam acesso aos recursos dos incentivos fiscais ${ }^{392}$.

Os grandes grupos que adquiriram terras no Acre constituíam-se principalmente de empresários do Sul do país que, na sua maioria, compraram áreas de terras ao longo da BR-364, em direção à cidade de Cruzeiro do Sul (sentido leste-oeste). Entretanto, foram os antigos pequenos e médios fazendeiros do Sul, transformados em grandes fazendeiros no Acre e, também, alguns grandes grupos com tradição pecuária, como o Bordon, que compraram as terras ao longo da BR-317 (Regionais de Desenvolvimento do Alto e Baixo Acre) e procederam a uma mudança no uso da terra. O desmatamento foi a principal prática dos "novos donos" da terra que tinham como perspectiva a criação de gado bovino para os mercados nacionais e futura exportação através do Pacífico. Mas, como as florestas já estavam ocupadas, desmatar significou o início de sérios conflitos ${ }^{393}$.

\subsubsection{Conflitos pela Posse da Terra no Acre e Resistência aos Desmatamentos}

A política de incentivo à implantação de empresas agropecuárias, iniciada na década de 1970, desencadeou grandes conflitos entre fazendeiros e posseiros em toda a Amazônia, tendo em vista que, após o colapso da economia da borracha, grupos sociais permaneceram na região dedicando-se a atividades agrícolas de subsistência ${ }^{394}$.

No Acre, as especificidades dos conflitos resultaram do fato da economia extrativa da borracha não ter se desestruturado totalmente no momento em que as empresas agropecuárias começaram a se implantar. Como consequência, dois modos de produzir entraram em confronto: "um que existia previamente e dependia da manutenção da base de recursos naturais para se reproduzir e outro que, para se implantar, requeria a destruição desta mesma base de recursos ${ }^{\prime 395}$.

\footnotetext{
392 GONÇALVES, Carlos Walter Porto. Geografando nos Varadouros do Mundo: da territorialidade seringalista (o seringal) à territorialidade seringueira (a Reserva Extrativista). Brasília: Ibama, 2003, p. 352.

${ }^{393}$ Id., 2003, p. 363.

${ }^{394}$ ALLEGRETTI, 2002, p. 191.

${ }^{395}$ Id., p. 191.
} 
Os seringueiros, ao permanecerem nas áreas onde exerciam suas atividades, passaram à condição de posseiros e logo iniciou-se o processo de expulsão. Vários foram os mecanismos para que os seringueiros saíssem das terras onde viviam: indenizações irrisórias pelas suas benfeitorias; expulsão sem qualquer indenização, por meio da intimidação e muitas vezes uso da violência ${ }^{396}$. Em depoimento à CPI do Sistema Fundiário, em setembro de 1979, o Bispo Dom Moacyr Grechi ${ }^{397}$, elencou os cinco principais métodos de expulsão dos seringueiros pelos novos donos da terra:

a) Não fornecimento de mercadorias para os seringueiros, obstrução de varadouros, proibição de desmatar e fazer roçados;

b) Destruição de plantações, invasão de posses, derrubadas até perto das casas dos posseiros, deixando-os sem ou quase sem terra para trabalhar;

c) Compra de posses e benfeitorias por preços irrisórios ou, quando muito, em troca de uma área muito inferior ao módulo, que não permita ao posseiro e família trabalhar e progredir;

d) Atuação de pistoleiros que amedrontam os posseiros numa guerra psicológica através de ameaças ou mesmo com espancamentos e outras violências;

e) Ameaças feitas por policiais a serviço de proprietários; prisões de posseiros por questões de terra sem ordem judicial ou por ordem judicial sem que tenha sido movida a ação competente ${ }^{398}$.

Segundo as denúncias do Bispo, podemos citar como exemplo, as arbitrariedades cometidas contra os seringueiros na Fazenda Paraná 2, desde 1973, divisa do Acre com Amazonas, de propriedade do paranaense Rômulo Bonalume:

\begin{abstract}
Cometeram-se aí as maiores barbaridades: foram contratados pistoleiros que intimidaram 70 famílias de posseiros, submetendo-as a uma série de humilhações. Os jagunços, com revólveres na cintura, impediam os posseiros de fazerem os roçados, de reformarem suas casas e até mesmo de fazerem reuniões de caráter religioso. Depois de tantas ameaças e humilhações, nem todos conseguiram suportar a situação; abandonavam suas posses e, para viver, tinham que se submeter em desmatamentos para aqueles mesmos que os expulsaram da terra ${ }^{399}$.
\end{abstract}

Além dos seringueiros, grupos indígenas seculares também sofreram com os grandes grupos econômicos que fizeram aquisição de terras na região. No imenso latifúndio de 463 mil hectares de terra no Rio Gregório, em Tarauacá, onde a empresa Paranacre alegava ser proprietária, existiam cerca de 300 índios Iauanauá e Katukina. O

\footnotetext{
${ }^{396}$ DUARTE, 1987, p. 63.

${ }^{397}$ Bispo da Prelazia do Acre e Purus, Presidente da Comissão Pastoral da Terra. No Acre, a Igreja foi durante muito tempo, o único canal de expressão do oprimido e a única entidade em que os expropriados ou ameaçados recorriam para pedir apoio e fazer suas denúncias (DUARTE, 1987, p. 63).

${ }^{398}$ Depoimento de D. Moacyr Grechi, na CPI do Sistema Fundiário, in Diário do Congresso Nacional, Seção I, Suplemento ao n 21, Capital Federal, 28/09/79, p. 310 apud DUARTE, 1987, p. 63.

${ }^{399}$ Id., p. 64.
} 
Chefe Iauanauá, em entrevista concedida ao jornal Varadouro, se expressou indignado com a situação:

Nós índios daqui do Rio Gregório consideramos esse Seringal Caxinauá e a Sete Estrelas, como nossa terra. Mas a firma Paranacre diz que a terra é deles, que eles compraram do Altevir Leal. Entonce quer dizer que o Altevir Leal vendeu a terra com nós tudim dentro? ${ }^{400}$

Segundo Duarte, os seringueiros que deixaram suas colocações, tomaram destinos variados, uns recorreram a outros patrões seringalistas e continuaram com a atividade extrativista da borracha, no sistema tradicional, sujeito ao seringalista; outros se apossaram de colocações em outros seringais e permaneceram como seringueiros autônomos e, ou, posseiros; ou migraram para a zona urbana das cidades ${ }^{401}$.

A região do Estado que mais gerou este tipo de migração foi a porção leste, que estava servida pelas rodovias BR-364 e Br-317, e contava com mais estabelecimentos com a prática da pecuária. A tabela com dados do IBGE, a seguir, demonstra a evolução da população urbana e rural nas décadas de 1960, 1970 e 1980.

Tabela 14 População Urbana e Rural no Estado do Acre: 1960, 1970 e 1980

\begin{tabular}{|c|c|c|c|c|c|}
\hline \multirow[t]{2}{*}{ ANO } & \multicolumn{2}{|c|}{ URBANA } & \multicolumn{2}{|c|}{ RURAL } & \multirow[t]{2}{*}{ TOTAL } \\
\hline & ABSOLUTA & $\%$ & ABSOLUTA & $\%$ & \\
\hline 1960 & 33.534 & 21,11 & 125.318 & 78,89 & 158.852 \\
\hline 1970 & 59.307 & 27,55 & 155.992 & 72,45 & 215.299 \\
\hline 1980 & 132.174 & 43,82 & 169.431 & 56,18 & 301.605 \\
\hline
\end{tabular}

Fonte: IBGE - Censos Demográficos - 1960, 1970 e 1980

Com podemos observar, os Censos Demográficos corroboram a migração de famílias que viviam na zona rural para zona urbana. Na década de 1960, do total de habitantes no Estado, quase $80 \%$ residiam no campo, mas essa taxa foi caindo nas décadas seguintes, para 72,45\% em 1970 e 56,18\% para 1980.

O destino dessas famílias não foi dos melhores. A maioria, sendo analfabetos e sem nenhuma qualificação profissional, dificilmente encontravam emprego na cidade, e quando eram contratados ficavam subordinados a serviços braçais, de forma temporária e mal remunerados. O excedente de pessoas que Rio Branco (capital) não esperava

\footnotetext{
${ }^{400}$ Varadouro n. 20, A qualquer sinal os jagunços podem sair da toca, Rio Branco, abril/81, p. 11 apud DUARTE, 1987, p. 64.

${ }^{401}$ DUARTE, 1987, p. 66.
} 
acabou por agravar os problemas sociais, aumentando a delinquência e prostituição. As famílias foram ocupando a periferia da cidade de Rio Branco, em locais não indicados para habitação como as margens dos rios, e regiões alagadiças ${ }^{402}$, áreas de preservação permanente (APP's), sem nenhuma infraestrutura.

Vale destacar ainda que muitos dos que foram expulsos dos seringais acreanos, preferiram migrar para o país vizinho, a Bolívia, em busca de novas áreas onde pudessem continuar suas atividades. Em 1979, a Confederação Nacional dos Trabalhadores na Agricultura (CONTAG), calculou que 5.000 famílias de seringueiros já haviam migrado para a Bolívia. Ainda no depoimento de D. Moacyr Grechi à CPI do Sistema Fundiário, em 1979, ele fez uma estimativa do número de acreanos que migraram tanto para o Bolívia quanto para o Peru, na perspectiva de trabalhar novamente na extração de borracha, entre 40 e 45 mil pessoas ${ }^{403}$.

Em entrevista dada ao jornal o Varadouro em 1978, o seringueiro Raimundo Pereira da Silva, 42 anos, explicou por que teve que imigrar:

Fui prá Bolívia porque os "paulistas" compraram o seringal onde eu trabalhava no Brasil. Aí fui obrigado a imigrar para a Bolívia porque eu só sei trabalhar na seringa e os "paulistas" não querem seringueiros em suas propriedades $^{404}$.

Enquanto isso, os seringueiros que preferiram resistir às pressões do novo modelo de reorganização do espaço acreano, sofreram com as tentativas de expulsão. Duarte trata de um dos primeiros confrontos considerados mais sérios que ocorreu no Seringal Catuaba, em Rio Branco onde, desde 1974, os posseiros resistiam às tentativas de expulsão por parte do "pseudo-proprietário" José Alexandre de Oliveira, que precisava limpar sua propriedade para depois vende-la a um grupo de pecuaristas. $\mathrm{O}$ posseiro Raul Veras acabou matando a tiros de espingarda o gerente do seringal, ferindo ainda um fiscal, quando ambos tentavam expulsar os seringueiros da área. Mas em 1976, o Juiz Federal em Rio Branco, determinou a expulsão de 300 posseiros $^{405}$.

Entre 1975 e 1979, o Estado do Acre ficou sob governo de Geraldo Gurgel de Mesquita, que buscou minimizar os problemas relacionados aos conflitos pela terra. Segundo Costa Sobrinho, o governo adotou uma política de não alinhamento

\footnotetext{
${ }^{402}$ DUARTE, 1987, p. 67.

403 Id., p. 67.

404 Entrevista de um seringueiro acreano, que foi expulso também da Bolívia, VARADOURO $\mathrm{n}^{\circ} 11$, Seringueiros acreanos - expulsos à bala da Bolívia. Rio Branco: agosto de 1978, p. 24 apud DUARTE, 1987, p. 67.

${ }^{405}$ DUARTE, 1987, p. 69.
} 
automático e direto aos interesses dos seringalistas e fazendeiros; tentou afastar a polícia militar e civil da questão da terra; procurou criar obstáculos e mesmo impedir a liberação de recursos de órgãos públicos estaduais e federais que financiavam empresários e fazendeiros; estimulou a ida para o Acre de órgãos federais como a FUNAI, EMBRAPA, INPA; fez pressões para que fossem ampliadas as instalações do INCRA, para que este órgão desempenhasse de modo eficiente e rápido, o trabalho de regularização e discriminação de terras, objetivando a desapropriação de áreas para a implantação de projetos de colonização e reforma agrária ${ }^{406}$.

As informações cedidas pelo Patrimônio Histórico e Cultural do Acre (Fundação Elias Mansour) também mostram que o governador Geraldo Mesquita foi um dos gestores que mais se destacaram no contexto histórico político do Acre, por sua divergência à política que transformou a economia acreana, adotada pelo antecessor Francisco Wanderley Dantas. Ele lutou pela implantação de Projetos de Assentamentos Dirigidos, os PAD's, que tinham por finalidade a utilização de terras federais devolutas através de sua doação aos sem-terra para que os mesmos pudessem morar e plantar para sustentar suas famílias ${ }^{407}$.

O governo de Geraldo Mesquita teve uma particularidade não encontrada em outros, o seu distanciamento da mídia durante todo o mandato, preferindo manter-se isolado, o que fez com que houvessem pouquíssimas matérias que falassem de seu governo.

Neste período, instalou-se no Acre a Confederação Nacional dos Trabalhadores na Agricultura (CONTAG) que estimulou o movimento sindical, e foi criada a Comissão Pastoral da Terra (CPT), que teve como Presidente o Bispo da Prelazia do Acre e Purus. Ainda no governo de Mesquita, foi criado o jornal alternativo " $O$ Varadouro, um jornal das Selvas", que tinha como objetivo tornar "possível a veiculação de opiniões dos que até então não tinham voz"408. A instalação da CONTAG, a criação da CPT e a publicação de um jornal alternativo deram nova configuração à luta dos seringueiros/posseiros pela terra.

Foi neste período que posseiros e seringueiros acreanos começaram a se organizar, evoluindo para as grandes mobilizações em torno dos sindicatos rurais. $\mathrm{O}$

\footnotetext{
${ }^{406}$ COSTA SOBRINO, 2000, p. 142.

407 PATRIMÔNIO HISTÓRICO E CULTURAL DO ACRE. Biografia dos Governadores do Acre. Fundação Elias Mansour, 2014. ${ }^{408}$ GONÇALVES, 2003, p. 403.
} 
Bispo Dom Moacyr Grechi, quando entrevistado pela antropóloga Eloisa Winter, fez a seguinte declaração:

[...] dias antes o governador Mesquita me disse que aqui não havia condições para sindicato e eu não sei o que respondi, mas creio que dois ou três dias depois a Catedral estava cheia, eu contei sentados oitocentas pessoas eu diria ter duas mil porque ela estava lotada (...). Eu me lembro que o Mesquita tomou a palavra contente porque o acreano finalmente se organizara. Mais de 2 mil em Rio Branco; 6000 em Sena Madureira; quase mil em Brasiléia; cerca de 800 em Cruzeiro do Sul; ainda 800 em Tarauacá; outros 700 em Feijó; e outros tantos trabalhadores em Xapuri. Em apenas dois anos, praticamente todos os municípios do Acre estavam cobertos pelos sindicatos rurais que, daí por diante, passaram a organizar e dar rumo à luta pela terra e pela reforma agrária, para os seus mais de 20 mil associados ${ }^{409}$.

Segundo Gonçalves, no final da década de 1970 a violência já não era tão difusa e sim direcionada contra lideranças de trabalhadores rurais, advogados e outros que militavam ao lado de entidades populares ${ }^{410}$.

A resistência dos seringueiros contra fazendeiros, no Vale do Acre ${ }^{411}$, resultou na morte de dois líderes sindicais que se destacaram, pela coragem e determinação, Wilson Souza Pinheiro e Francisco Alves Mendes Filho (Chico Mendes). Estes sindicalistas foram incessantes na luta contra o desmatamento de áreas onde os seringueiros ainda trabalhavam e tiravam seu sustento. Eles tiveram uma trajetória social semelhante e o mesmo destino.

Wilson Pinheiro foi seringueiro, Presidente do Sindicato dos Trabalhadores Rurais (STR) de Brasiléia e da Comissão de Fundação do Partido dos Trabalhadores (PT), iniciou sua carreira como delegado sindical em 1975 e foi assassinado em 21 de julho de 1980¹2; Chico Mendes também foi seringueiro, secretário do STR de Brasiléia e presidente do STR de Xapuri, vereador em dois períodos de 1977-1980 e de 19801982, exerceu a Presidência da Câmara dos Vereadores de Xapuri em 1981, deu início ao seu trabalho sindical no mesmo ano do líder Wilson e, foi assassinado em $1988^{413}$.

\footnotetext{
${ }^{409}$ Apud COSTA SOBRINO, 2000, p. 142-143. O livro não informa a data da realização da entrevista.

${ }^{410}$ GONÇALVES, 2003, p. 403. Vários professores da Universidade Federal do Acre foram afastados por suas notórias posições políticas, assim como muitos daqueles que militavam em entidades que faziam a defesa dos direitos humanos,

${ }^{411}$ Essa região foi classificada pelo IBGE como: Microrregião do Alto Acre e Microrregião do Baixo. Acre.

${ }^{412}$ ALLEGRETTI, 2002, p. 192; GONÇALVES, 2003, p. 403.

${ }^{413}$ ALLEGRETTI, 2002, p. 192.
} 


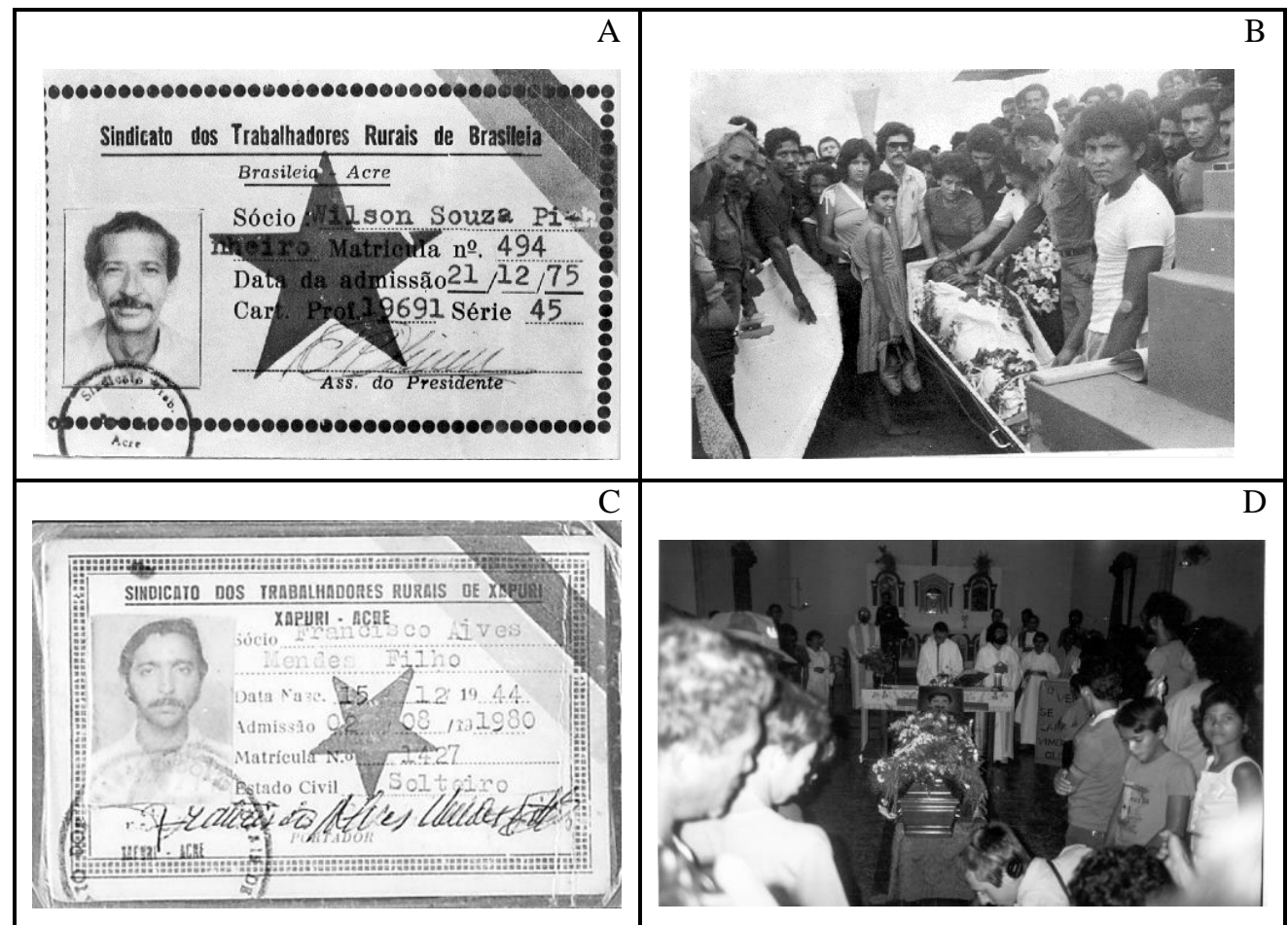

Figura 3: Vida e Morte dos líderes sindicais Wilson Souza Pinheiro e Francisco Alves Mendes Filho.

A - Carteira do STR de Brasiléia de Wilson Souza Pinheiro; B - Enterro de Wilson Souza Pinheiro em 1980; C - Carteira do STR de Xapuri de Francisco Alves Mendes Filho (Chico Mendes); D - Velório de Chico Mendes, Igreja de Xapuri, em 1988.

Fonte: Acervo Comissão Pastoral da Terra, Acervo Digital do Departamento de Patrimônio Histórico e Cultural do Acre - FEM.

Para o líder Chico Mendes a região mais afetada com os conflitos foi o Vale do Acre, tendo em vista a abertura da BR-317 no ano de 1971, que facilitou o acesso entre a capital, Rio Branco, aos municípios de Brasiléia (fronteira com Bolívia), Xapuri e Assis Brasil (fronteira com o Peru), fato estimulador para a compra de terras e circulação de pessoas naquela região.

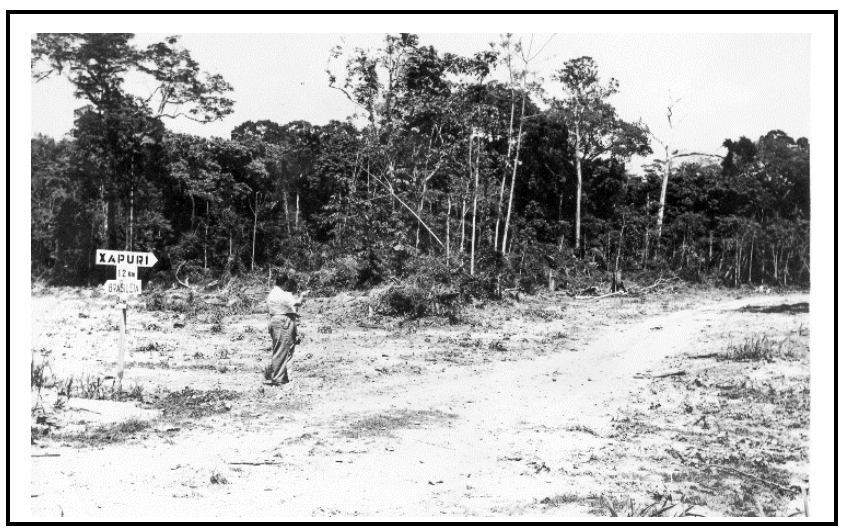

Figura 4: Estrada de terra: ligação entre os municípios de Xapuri e Brasiléia, década de 1970.

Fonte: Patrimônio Histórico e Cultural do Acre (Fundação Elias Mansour). 
Em entrevista concedida à pesquisadora Mary Allegretti, para sua tese de doutorado intitulada "A construção Social de Políticas Ambientais - Chico Mendes e o Movimento dos Seringueiros", o líder Mendes, declarou que:414

[...] E em poucos anos, e a partir de 70 até 77, mais de 10 mil famílias de seringueiros foram expulsas através dos métodos mais violentos possível. Xapuri foi o município ... a maior vítima dessa violência. Dezenas de jagunços foram mandados para os seringais, derrubar a casa dos seringueiros, queimar os barracos dos seringueiros, seringueiros que moravam desde muitos anos, que nasceram e se criaram na selva, foram de repente obrigados a sair sem receber nenhum tostão pelos seus bens, pelo seu trabalho e o desespero dominou essa população de modo que uma grande parte deles, de 10 a 15 mil, talvez 50\%, foi tentar a vida na cidade. Rio Branco foi, realmente, a cidade de preferência para o êxodo desse pessoal e como não tinham trabalho, não tinham profissão nenhuma, não tinham saber nenhum, só sabiam cortar seringa, fazer a borracha e cortar a castanha, aí foram e ocuparam as periferias das cidades [...] A outra parte, grande parte, que achou que tentar a vida na cidade seria arriscado demais, se mandou para a Bolívia, e hoje, por exemplo, nós não temos uma previsão segura, mas se prevê que 10 a 20 mil famílias de seringueiros se encontram em território boliviano, peruano, na Amazônia internacional.

No ano de 1976, o antigo Seringal Carmem, transformado na Fazenda Carmem, no município de Brasiléia, foi palco do primeiro conflito que caracterizou a resistência dos seringueiros à expulsão de suas terras, denominado empate ${ }^{415}$. Os seringueiros do antigo seringal, se reuniram e resolveram defender suas posses, impedindo o desmatamento realizado por peões contratados pelo novo dono da área, que tinha como objetivo desmatar e dividir a terra em colônias para serem revendidas a colonos vindos do sul do Brasil. Estavam iniciando os primeiros grandes movimentos sociais pela terra na região ${ }^{416}$.

Para o líder Chico Mendes, o empate foi uma forma que os trabalhadores encontraram de impedir o avanço do latifúndio e defender sua própria sobrevivência:

[...] Uma espécie de uma bandeira que eles, entre si, pensaram que seria o último apelo, já que às vezes eles recorriam à justiça e o processo era muito lento. Enquanto eles recorriam à justiça, enquanto isso, a floresta ia sendo derrubada, de qualquer maneira. Então, isso não levava vantagem nenhuma pro trabalhador, porque ele ia perdendo terreno, diariamente. Então ele pensou uma outra forma. Não em termos de querer ser um agitador, como ele é acusado, muitas vezes, de agitar, e tal, de ter orientações, nunca. Mas seria a única saída para ele defender os seus direitos, a sua própria sobrevivência. É incrível dizer, muita gente até não acredita, que o trabalhador chegou a dizer que dessa forma ele estaria cooperando para a segurança nacional: empatar o

\footnotetext{
${ }^{414}$ ALLEGRETTI, 2002, p. 207.

415 O termo empatar, no linguajar amazônico, quer dizer impedir, neste caso, as derrubadas ou desmatamentos.

${ }^{416}$ ALLEGRETTI, 2002, p. 235
} 
desmate, quer dizer, defender a seringueira e a castanheira, que é a sobrevivência deles, da família deles, isso desde o século passado, e que ele considera também como seja a única fonte de riqueza do Estado, ainda é, prevalece, apesar de toda a destruição, é a seringa e a castanha ${ }^{417}$.

A figura 5 retrata a luta dos seringueiros organizados para empates. Uma disputa acirrada pelo o uso da terra em sua forma tradicional - o extrativismo - contra as grandes empresas, especuladores e pecuaristas. Os conflitos foram ferrenhos e provocaram diversas mortes, tanto dos que lutavam pela permanência das atividades extrativistas, como dos que queriam derrubar a floresta para implantação da pecuária na região.

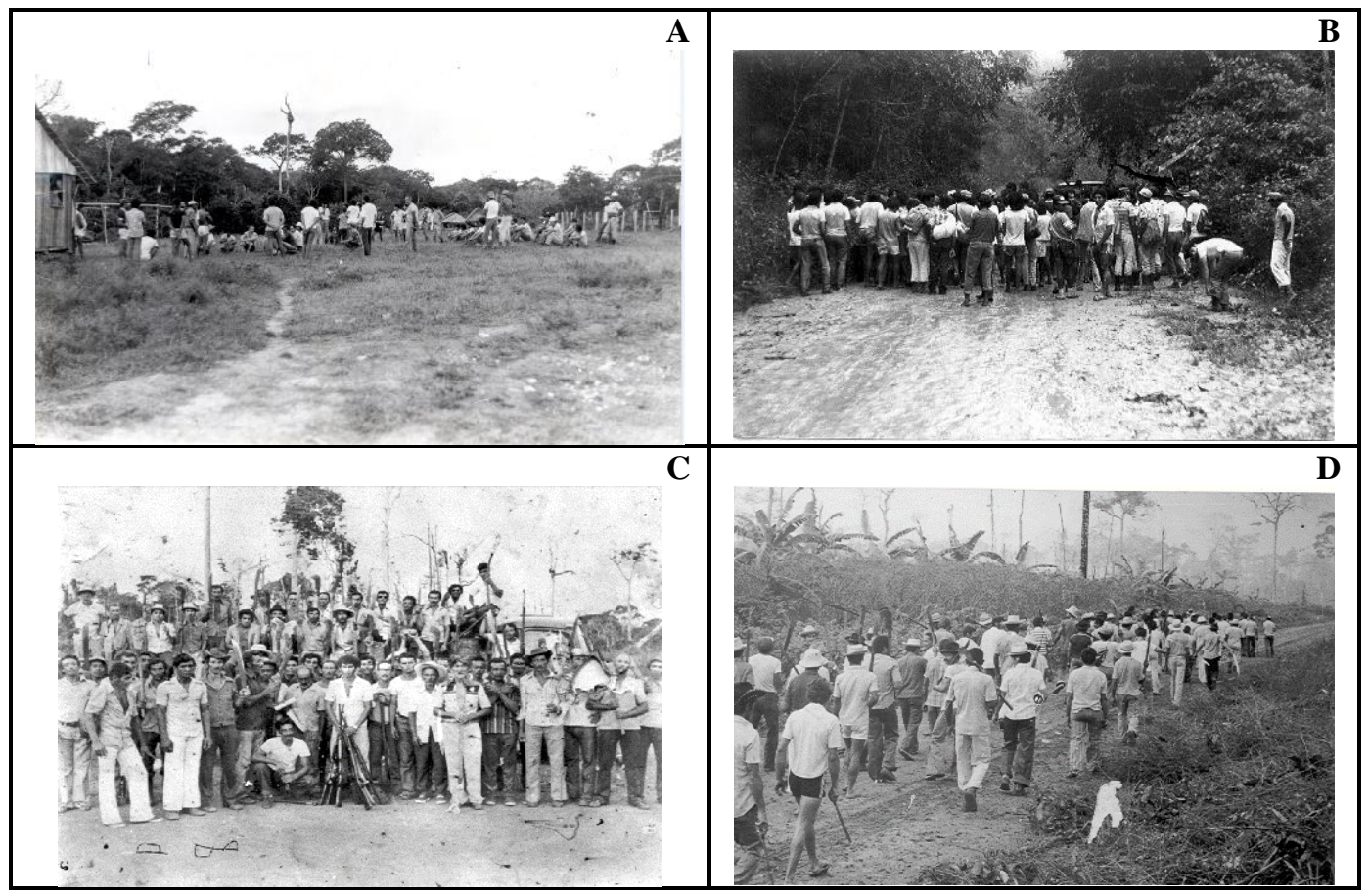

Figura 5 Seringueiros na luta contra os desmatamentos causados pelos novos latifundiários do Acre. A - Seringueiros reunidos para organizar os empates, década de 1970; B - Trabalhadores rurais reunidos para empate contra os "paulistas", década de 1970; C - Empate na estrada de Boca do Acre - AM, setembro de 1979; D - Seringueiros armados com terçados e foices para empate no Km 38 da BR-317, Boca do Acre-AM, década de 1970.

Fonte: Acervo Comissão Pastoral da Terra e Acervo Digital do Departamento de Patrimônio Histórico e Cultural do Acre - FEM.

Frente aos graves problemas sociais gerados pela disputa da terra, o governo federal em parceria com o estadual, procuraram amenizar a situação. Desde a gestão do governador Geraldo Mesquita (1975-1979), houve um estímulo ao setor agrícola, voltado para a produção de gêneros de subsistência, além dos incentivos à reativação de seringais nativos, e implantação de seringais de cultivo. Para tanto, foi providenciada

${ }^{417}$ Id., p. 190. 
uma infraestrutura visando o apoio ao pequeno produtor ${ }^{418}$, surgindo a partir daí a Companhia de Desenvolvimento Agrário e Colonização do Acre ${ }^{419}$ (COLONACRE), e a Companhia de Armazéns Gerais do Acre ${ }^{420}$ (CAGEACRE), ambas criadas em 1975.

Outro recurso utilizado foi a desapropriação de terras por interesse social. A primeira delas ocorreu por meio do Decreto $\mathrm{n}^{\mathrm{o}} 79.048$ de 27 de dezembro de 1976, que autorizou o INCRA a promover a desapropriação dos imóveis rurais de uma área de aproximadamente 292.000,00 hectares, no município de Sena Madureira ${ }^{421}$. A desapropriação tinha como objetivo a implantação do Projeto Boa Esperança, que visava o plantio de seringueiras, e o assentamento de 442 famílias ${ }^{422}$.

$\mathrm{Na}$ mesma data, o Decreto $\mathrm{n}^{\mathrm{o}} 79.049$ desapropriou uma área de aproximadamente 408.000,00 hectares, localizada no município de Rio Branco, transcrita em nome de diversos particulares ${ }^{423}$. A área em desapropriação abrangeu as terras dos seringais Bagaço, Triunfo, União, São Vicente, Floresta, Campo Belo e Bom destino, que cobriu ainda boa parte dos municípios de Plácido de Castro e Senador Guiomard. O objetivo dessa desapropriação foi a implantação do Projeto de Assentamento Dirigido (PAD) Pedro Peixoto, localizado na zona de influência da BR364 e AC-475, que assentou 3.815 famílias, entre seringueiros e colonos vindos do Sul do país ${ }^{424}$.

De forma gradativa, o governo do Estado, em parceria com o INCRA continuaram a desapropriação, "levando em consideração a ociosidade da terra, a demanda migratória na região e a frequências dos conflitos entre posseiros $e$

\footnotetext{
${ }^{418}$ DUARTE, 1987, p. 76.

419 ACRE. Lei n. 560, de 10 de julho de 1975. "Autoriza a constituição da Companhia do Desenvolvimento Agrário e Colonização do Acre - COLONACRE. Rio Branco: 1975.

${ }^{420}$ ACRE. Lei n. 564, de 26 de setembro de 1975. "Autoriza a constituição da Companhia de Armazéns Gerais e Entrepostos do Estado do Acre - CAGEACRE. Rio Branco: 1975.

${ }^{421}$ BRASIL. Decreto no 79.048, de 27 de dezembro de 1976. Declara de interesse social, para fins de desapropriação, imóveis rurais situados no Município de Sena Madureira, Estado do Acre, compreendidos na área prioritária de Reforma Agrária, assim declarada pelo Decreto $n^{\circ}$ 67.557, de 12 de novembro de 1970, e ampliada pelo Decreto ${ }^{\circ} 75.295$, de 27 de janeiro de 1975. Brasília: 1976.

${ }^{422}$ INCRA - Coordenadoria Especial da Amazônia Ocidental apud DUARTE, 1987, p. 77-78.

${ }^{423}$ BRASIL. Decreto no 79.049, de 27 de dezembro de 1976. Declara de interesse social, para fins de desapropriação, imóveis rurais situados no Município de Rio Branco, Estado do Acre, compreendidos na área prioritária de Reforma Agrária, assim declarada pelo Decreto n 67.557, de 12 de novembro de 1970, e ampliada pelo Decreto ${ }^{\circ}$ 75.295, de 27 de janeiro de 1975. Brasília: 1976.

${ }^{424}$ DUARTE, 1987 , p. 77-78. Os posseiros localizados na área deveriam ter sua situação regularizada de acordo com o Estatuto da Terra, entretanto, por pressões dos proprietários e dos políticos, que conduziam a questão junto ao INCRA em Brasília, para que este projeto fosse desativado, resultou em atraso na sua implantação e sofreu uma redução em termos de área. Parte da área foi cedida ao Projeto Redenção, coordenado pela COLONACRE, e depois de uma grande celeuma com os ex-proprietários, e pressões dos trabalhadores sem-terra, que iniciaram uma invasão na área, o INCRA reativou o Projeto em 1980.
} 


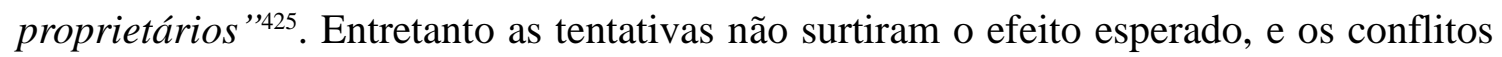
sociais permaneceram agudos durante toda a década seguinte.

Mas, não podemos deixar de destacar a atuação dos sindicalistas rurais, que continuaram a defender o direito de ocupação das áreas onde viviam. Entretanto, as associações dos seringueiros, estabelecidas no primeiro momento, nos municípios de Brasiléia e Xapuri, não conseguiram deter o avanço do desmatamento das florestas habitadas pelos seringueiros.

Os conflitos fundiários e os empates continuaram cada vez mais crescentes, culminando, como já vimos, na morte de Wilson Pinheiro, primeiro líder sindical do município de Brasiléia. Depois da morte de Wilson, Chico Mendes ainda deu continuidade aos empates no município de Xapuri, ampliando sua visibilidade como líder, em defesa da terra.

Os sucessivos empates, endossados pelas reivindicações do Conselho Nacional do Seringueiro (CNS) - organização fundada em 1985 - resultaram na institucionalização de duas modalidades de áreas destinadas a populações extrativistas. A primeira, regularizada e coordenada pelo INCRA, se constituiu nos Projetos de Assentamento Extrativista (PAE's); e, logo depois, as Reservas Extrativistas (RESEX's), subordinadas ao IBAMA. Tais modalidades surgiram em resposta às demandas apresentadas pelos seringueiros, no Primeiro Encontro Nacional dos Seringueiros, sediado em Brasília, em 1985, que reivindicavam a desapropriação dos seringais nativos; a definição de áreas ocupadas por seringueiros como Reservas Extrativistas; além de novas políticas de desenvolvimento para a Amazônia, que reconhecessem as suas comunidades tradicionais ${ }^{426}$.

Os PAE's foram legalizados em 1987, através da Portaria n. 627-INCRA de 30 de julho, constituindo-se na época, um modelo de reforma agrária inovador na região amazônica. Com a morte de Chico Mendes em 1988, a luta dessa comunidade ganhou repercussão, criando uma pressão nacional e internacional sobre o governo brasileiro, no que diz respeito a uma solução para os conflitos de natureza sócio-ambiental na Amazônia. Toda essa situação culminou na criação das RESEX's, através do Decreto n. 98.897 de 30 de janeiro de 1990, como unidade de conservação de uso indireto, definido como "espaços territoriais destinados à exploração auto-sustentável e conservação dos

${ }^{425}$ DUARTE, 1987, p. 77.

${ }^{426}$ ACRE, 2000, p. 101-102. 
recursos naturais renováveis, por população extrativista", ficando sob responsabilidade do IBAMA ${ }^{427}$.

Neste contexto, foram criadas em 1990, no Estado do Acre, as duas primeiras RESEX'S do país, a Reserva Extrativista do Alto Juruá, e a Reserva Extrativista Chico Mendes.

A Reserva Extrativista do Alto Juruá (REAJ) foi a primeira RESEX criada no país e no Estado do Acre, através do Decreto nº 98.863 de 1990. O decreto, além de afirmar tratar-se de reserva de interesse ecológico e social, determinava que sua área seria de 537.946,47 hectares, conforme o Mapa $3^{428}$.

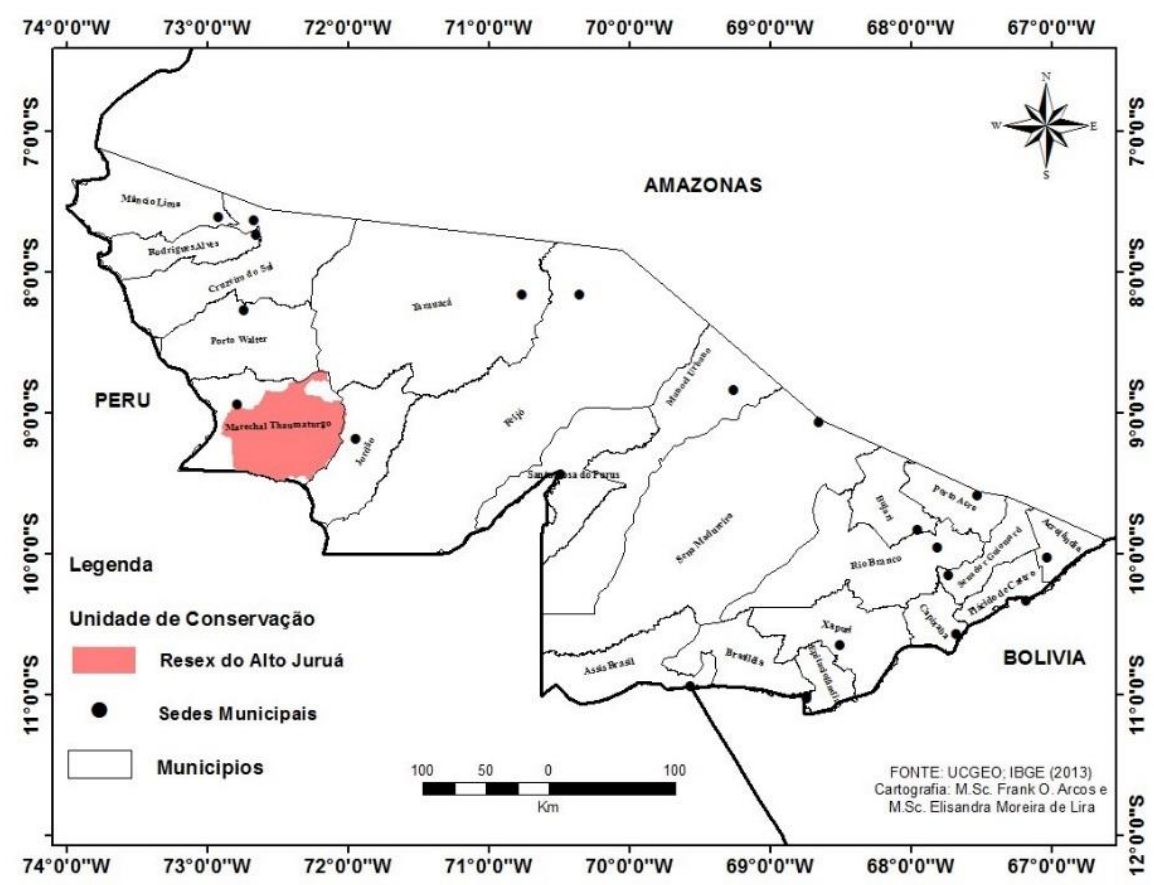

Mapa 3 Localização Geográfica da Reserva Extrativista Alto Juruá-AC.

Na justificativa de proposição da nova RESEX, elaborada pelo Ministro do Interior, ao qual estava ligado o IBAMA (a quem coube a responsabilidade da unidade de conservação), estava registrado que a Reserva possibilitaria a conservação dos recursos renováveis existentes, bem como sua exploração de forma sustentável por populações consideradas de tradição extrativista e que já habitassem a região. Com a criação desse tipo de unidade, tornava-se possível conciliar ações extrativistas, principalmente a exploração da borracha em seringais nativos (principal atividade

${ }^{427}$ BRASIL. Decreto n. 98.897, de 30 de janeiro de 1990. Dispõe sobre as Reservas Extrativistas e dá outras providências.

${ }^{428}$ BRASIL. Decreto $\mathbf{n}^{\mathbf{0}} \mathbf{9 8 . 8 6 3}$, de 23 de janeiro de 1990. Cria a Reserva Extrativista do Alto Juruá. Brasília: 1990. 
econômica da região), com a conservação da natureza, especialmente pela presença de endemismos e diversidades biológicas específicas da região ${ }^{429}$.

A RESEX Chico Mendes foi a segunda a ser criada no Acre, localizada na região sudeste do Estado, com uma área aproximada de 970.570 hectares $^{430}$, abrangendo terras dos municípios de Assis Brasil, Brasiléia, Capixaba, Xapuri, Sena Madureira e Rio Branco (Mapa 4) ${ }^{431}$.

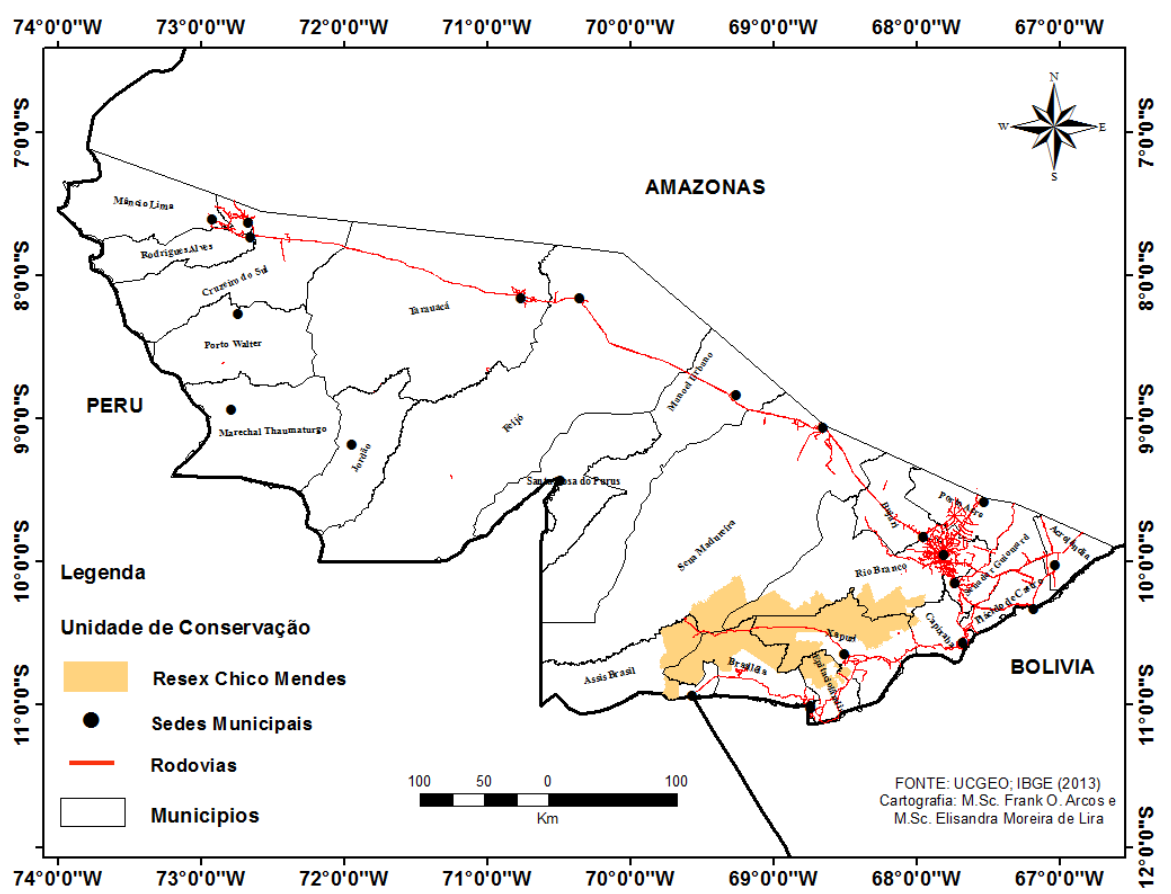

Mapa 4 Localização Geográfica da Reserva Extrativista Chico Mendes-AC.

Por fim, podemos concluir que tanto os PAE's quanto as RESEX'S foram uma conquista dos seringueiros e também um avanço nas políticas nacionais de reforma agrária e meio ambiente ${ }^{432}$.

\footnotetext{
${ }^{429}$ ALLEGRETTI, 2008, p.48.

${ }^{430}$ BRASIL. Decreto $\mathbf{n}^{\mathbf{0}}$ 99.144, de 12 de março de 1990. Cria a Reserva Extrativista Chico Mendes. Brasília: 1990.

${ }^{431}$ Hoje seu acesso é feito pela rodoviária BR-317 e por via fluvial, através do Rio Xapuri e afluentes, exceto no período de seca, pois devido ao baixo nível de água e a formação de enormes bancos de areia, a navegação fica praticamente impossível. Outro acesso viável se dá pelos rios Iaco e Macauã, na porção mais ocidental da Reserva, pelo município de Sena Madureira. IBAMA, 2006, p. 12.

${ }^{432}$ ACRE, 2000, p. 102.
} 


\subsection{A Implantação das Primeiras Unidades de Conservação Federais no} Acre

Frente a grande devastação que a região amazônica vinha sofrendo com as políticas de integração nacional do governo federal, muitas críticas foram surgindo para este modelo de ocupação. Durante os eventos internacionais de defesa da natureza, aumentou-se a cobrança para que o país protegesse melhor seus recursos naturais, o que levou o governo a desenvolver estudos sobre a região. Estes estudos serviram como base para o reconhecimento da biodiversidade existente na Amazônia, além de indicarem a necessidade de criação de unidades de conservação, seja de uso direto ou indireto, afim de proteger a natureza dos impactos provocados pelas atividades antrópicas.

Dentre os principais estudos desenvolvidos na década de 1970 e 1980, para a região amazônica, destacamos: o PROJETO RADAMBRASIL, que operou de $1970 \mathrm{e}$ 1985, com realização de imagens de radar; o Programa de Polos Agropecuários e Agrominerais da Amazônia (POLAMAZÔNIA), de 1974, criado para determinação de áreas para a exploração agrícola, pecuária, florestal e mineral; o relatório "Uma Análise de Prioridade para a Conservação da Natureza na Amazônia”, publicado pelo IBDF, em 1976, que tinha o objetivo de identificar áreas para preservação; e por último a II Etapa do "Plano do Sistema de Unidades de Conservação do Brasil" - PSUC, também publicado pelo IBDF em parceria com a FBCN, em 1982, que realizou estudos para embasar a indicação e implantação de áreas de conservação no país.

O Projeto RADAMBRASIL e o POLAMAZÔNIA, foram produtos dos planos de integração nacional. Mesmo assim, foram de fundamental importância para o reconhecimento da região e, ao final de cada relatório publicado continham sugestão de criação de áreas de proteção ambiental, partindo de critérios tanto de beleza cênica, como da riqueza de fauna e flora das regiões estudadas. Já as pesquisas publicadas pelo IBDF, estavam voltadas especificamente para a implantação de um sistema nacional de unidades de conservação no país, também levando à sugestão de criação de diversas áreas, com a finalidade de proteção e conservação de ecossistemas. Todos esses relatórios serão melhor detalhados no cap. 4 deste trabalho, quando serão apresentados como subsídios para a criação do Parque Nacional da Serra do Divisor, Acre, nosso foco de estudo. 
Antes que se iniciasse o período dos governos militares, havia na região amazônica apenas uma área protegida, na categoria de uso direto, a Floresta Nacional de Caxiuanã. Como vimos no cap. 2, ela foi criada em 1961 pelo Decreto n. 239 de 28 de novembro, com área de 200.000,00 hectares, no Estado do Pará.

No período militar, foram criadas na Amazônia, dezenove unidades de conservação entre 1974 a 1984. Foram implantados cinco Parques Nacionais, cinco Reservas Biológicas, sete Estações Ecológicas, uma Floresta Nacional, e uma Área de Relevante Interesse Ecológico. Ao todo, estas unidades cobriram 10.591.942,37 hectares, ou seja, 105.919,42 $\mathrm{Km}^{2}$.

Como podemos observar no mapa 5, a maioria das unidades de conservação criadas, concentraram-se no Estado do Amazonas. As outras, foram distribuídas pelos Estados do Pará, Rondônia, Roraima, Amapá e Acre (ver tab. 15 em anexo).

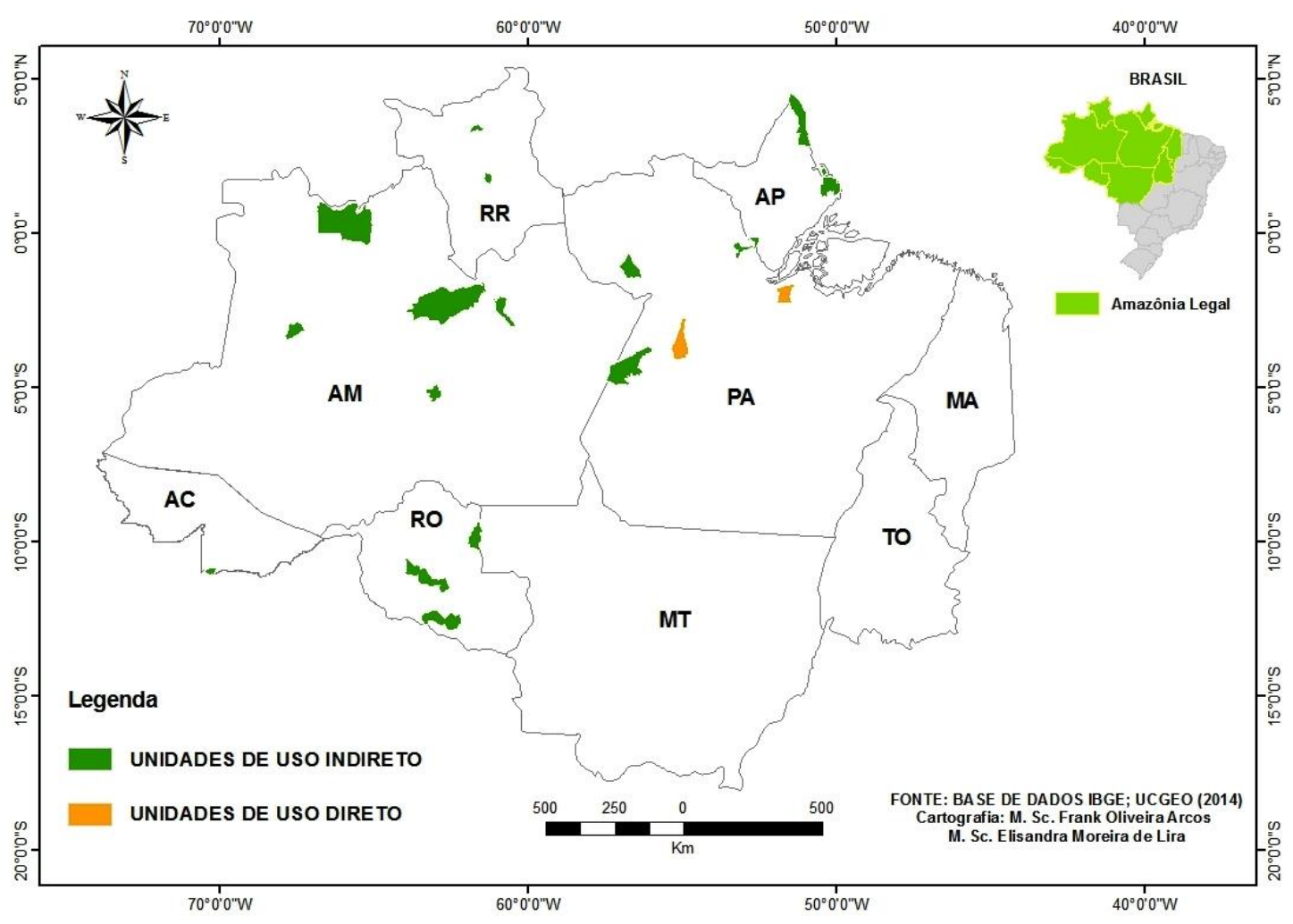

Mapa 5 Unidades de Conservação criadas na Amazônia Legal no regime militar.

\subsubsection{A criação das primeiras unidades de conservação no Estado do Acre - 1980}

Como já mencionado no cap. 2, depois da publicação do "Mapa Florestal do Brasil”, foi sugerida a criação de uma área de Reserva Florestal no Território do Acre, através do Decreto Federal $\mathrm{n}^{\circ} 8.843$ de 26 de julho de 1911, que abrangeria 
aproximadamente 2,8 milhões de hectares (sob a jurisdição do Ministério da Agricultura, Indústria e Comércio $)^{433}$. Com base neste Decreto, a justificativa de criação dessa reserva florestal se dava em resposta à destruição das florestas, que estaria afetando todo o país, com alterações no clima e no regime das águas pluviais. Mas, como vimos, a proposta de criação da reserva foi esquecida.

Apenas em 1981, parte da área proposta para a criação de uma reserva florestal em 1911, foi transformada na primeira unidade de conservação do Estado. A Estação Ecológica do Rio Acre (EERA), uma unidade de proteção integral. Criada pelo Decreto $\mathrm{n}^{\circ} 86.061 / 81$, com uma área de 77.500,00 ha ${ }^{434}$ (representando na época 0,5\% da área do Estado), e 146.130 metros de perímetro. A EERA está localizada na região sudeste do Estado do Acre, Gleba Abismo, município de Assis Brasil, limitando-se ao Norte com a Terra Indígena Mamoadate, ao Leste com a Terra Indígena Cabeceira do Rio Acre, ao Sul e Oeste com o Peru (Mapa 6). O objetivo de sua criação baseava-se no desenvolvimento de projetos de pesquisa e na preservação de parte das nascentes do rio Acre $^{435}$.

\footnotetext{
${ }^{433}$ BRASIL. Decreto n. 8.843, de 26 de julho de 1911. Cria a reserva florestal no Território do Acre. Rio de Janeiro: 1911.

${ }^{434}$ BRASIL. Decreto $\mathbf{n}^{\mathbf{0}}$ 86.061, de 2 de junho de 1981. Cria Estações Ecológicas, e dá outras providências. Brasília: 1981. (Este foi um Decreto único que criou as primeiras oito Estações Ecológicas no país. Além da Estação Ecológica Rio Acre mais três unidades foram criadas no bioma amazônico, a Estação Ecológica de Anavilhanas no Amazonas, a Estação Ecológica de Maracá - Jipioca no Amapá e a Estação Ecológica de Maracá em Roraima; duas no Cerrado, a Estação Ecológica Uruçuí-Una e a Estação Ecológica de Iquê; uma na Mata Atlântica, a Estação Ecológica Aracuri-Esmeralda; e uma no Pantanal, a Estação Ecológica do Taiamã).

${ }^{435}$ ICMBio. Instituto Chico Mendes de Conservação da Biodiversidade. Plano de Manejo - Estação
} Ecológica Rio Acre. Brasília: ICMBio, WWF, SOS AMAZÔNIA, 2010, p. 6-7. 


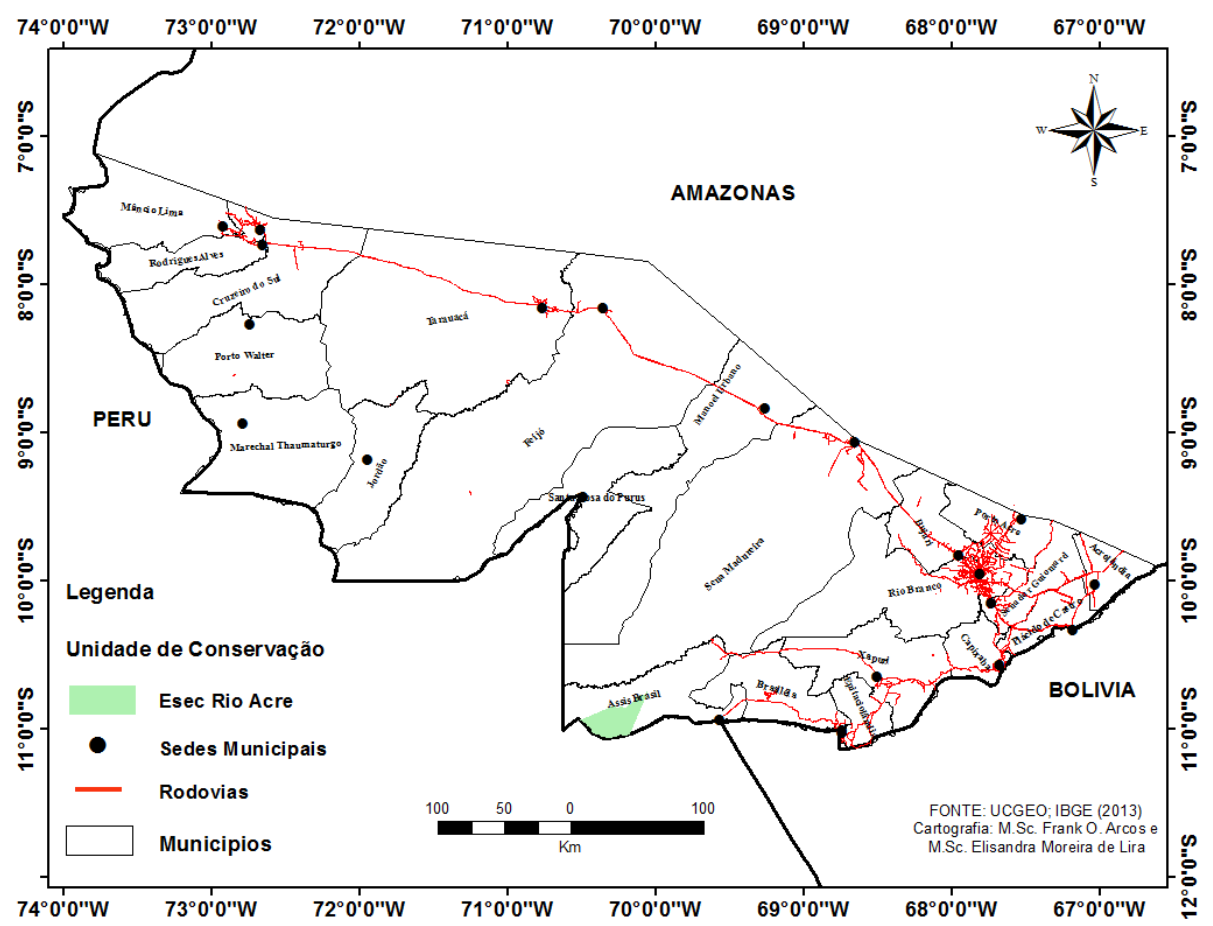

Mapa 6 Localização Geográfica da Estação Ecológica Rio Acre-AC.

O nome da Estação está relacionado à existência, na região, do próprio Rio Acre. Já o nome Acre surgiu de "Aquiri", que significa "rio dos jacarés" na língua nativa dos índios Apurinãs, habitantes originais da região banhada pelo rio, que empresta o nome ao Estado.

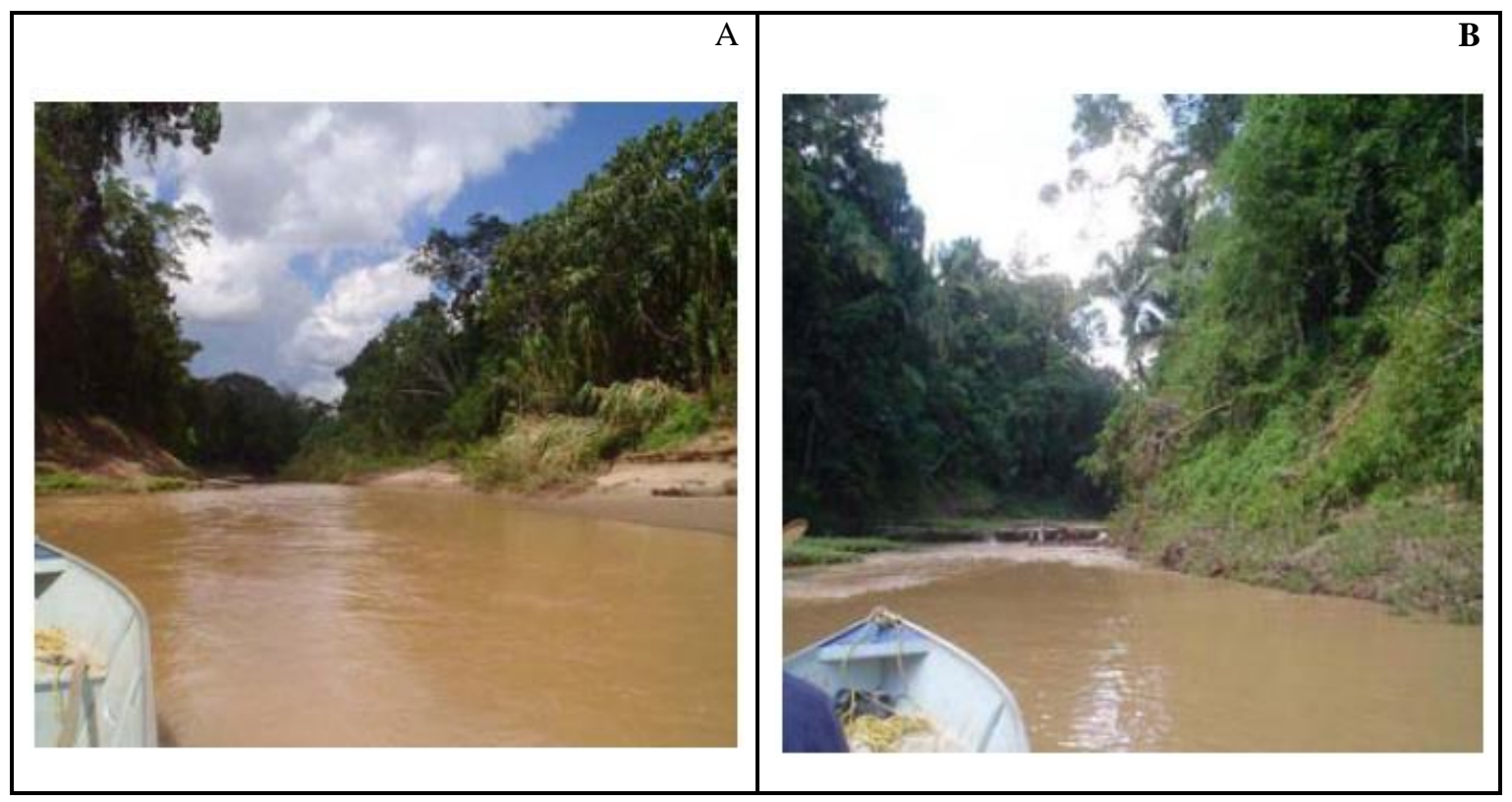

Figura 6 Aspectos da hidrografia da bacia do Rio Acre - leitos encaixados.

Fonte: PASSOS apud ICMBio, 2010, p. 84. 
A Estação Ecológica Rio Acre, está localizada em uma região considerada prioritária para a conservação da biodiversidade, uma das maiores concentrações mundiais de áreas protegidas adjacentes e fronteiriças, que formam um mosaico ${ }^{436}$ contínuo de áreas protegidas, abrangendo uma extensão de aproximadamente 8,8 milhões de hectares. ${ }^{437}$

Ao fazer limite com a Província de Iñapari, localizada na região de Madre de Dios, no Peru, a EERA se aproxima de uma área de Concessão Madeireira e de uma reserva de índios isolados, além de um parque nacional e uma reserva comunal, formando ao longo da fronteira Brasil-Peru um mosaico contínuo de terras protegidas de pouco mais de 4,2 milhões de hectares. E é justamente nesta região que estão localizadas as nascentes de importantes rios para o Estado do Acre, como o Chandless, Purus, Envira, Juruá e Amônia e, ainda a bacia tri-nacional do Alto Rio Acre, abrangendo áreas da Bolívia (Bolpebra, Polvenir e Cobija), Brasil (Assis Brasil, Brasiléia, Epitaciolância, Xapuri e parte de Sena Madureira) e Peru (província de Iñapari). ${ }^{438}$

Passados sete anos, após o período militar, em 1988, foi criada a segunda unidade de conservação do Acre. Trata-se da Floresta Nacional do Macauã, com extensão de 173.475,00 hectares, subordinada e integrante da estrutura básica do IBDF. $^{439}$ Sua criação, como a maioria das Florestas Nacionais da Amazônia, ocorreu durante o governo de José Sarney ${ }^{440}$.

A Floresta Nacional do Macauã está localizada no Município de Sena Madureira (Mapa 7) às margens do Rio Macauã, afluente do rio Iaco. Pertencente à bacia hidrográfica do rio Purus. Seu acesso se dá pelo município de Sena Madureira (onde fica o escritório da unidade), por via fluvial, através dos rios Iaco e Macauã, no período de chuvas (novembro a abril), e por via terrestre através de um ramal com

\footnotetext{
${ }^{436}$ Para melhor entendermos o termo mosaico no contexto das unidades de conservação, o Artigo 26 da Lei $n^{\circ} 9.985$ de 18 de julho de 2000 o define como um conjunto de unidades de conservação de categorias diferentes ou não, próximas, justapostas ou sobrepostas a outras áreas protegidas públicas ou privadas geridas de forma integrada, transparente e participativa, considerando os seus distintos objetivos de conservação, de forma a compatibilizar a presença da biodiversidade, a valorização da sociodiversidade e o desenvolvimento sustentável no contexto regional (BRASIL. Lei $\mathbf{n}^{\mathbf{0}} \mathbf{9 . 9 8 5}$, de 18 de julho de 2000. Regulamenta o art. 225, § 1ํㅡㄹ incisos I, II, III e VII da Constituição Federal, institui o Sistema Nacional de Unidades de Conservação da Natureza e dá outras providências. Brasília: 2000).

${ }^{437}$ ICMBio, 2010, p. 81

${ }^{438}$ Id., p. 82.

${ }^{439}$ BRASIL. Decreto no 96.189, de 21 de junho de 1988.Cria, no Estado do Acre, a Floresta Nacional do Macauã, com limites que especifica, e dá outras providências. Brasília: 1988.

${ }^{440}$ Desde de 1965 o Código Florestal (Lei no 4.771), instituiu a Florestas Nacionais (FLONAS), bem como as Reservas Biológicas (REBIO) e as Áreas de Preservação Permanentes (APP).
} 
extensão aproximada de $150 \mathrm{~km}$ até a sede da associação de moradores. Boa parte dete, sem condições de trafegabilidade, mesmo no período de estiagem (maio a outubro) ${ }^{441}$.

Os moradores da Flona do Macauã, são descendentes de famílias de seringueiros que ocuparam a região no fim do século XIX, provenientes do fluxo migratório Nordeste-Norte, que se deslocaram para trabalhar na atividade extrativa da borracha, no período conhecido como do "ouro negro". Entretanto, depois da falência da economia da borracha, boa parte das famílias que viviam no rio Macauã abandonaram os seringais para aventurar-se nas cidades de Sena Madureira e Rio Branco. Os troncos familiares que permaneceram, repovoaram a região do alto Macauã. Até a publicação do Plano de Manejo, em 2009, existiam 14 famílias habitando na área do antigo seringal Caíco, que se transformou na Flona ${ }^{442}$.

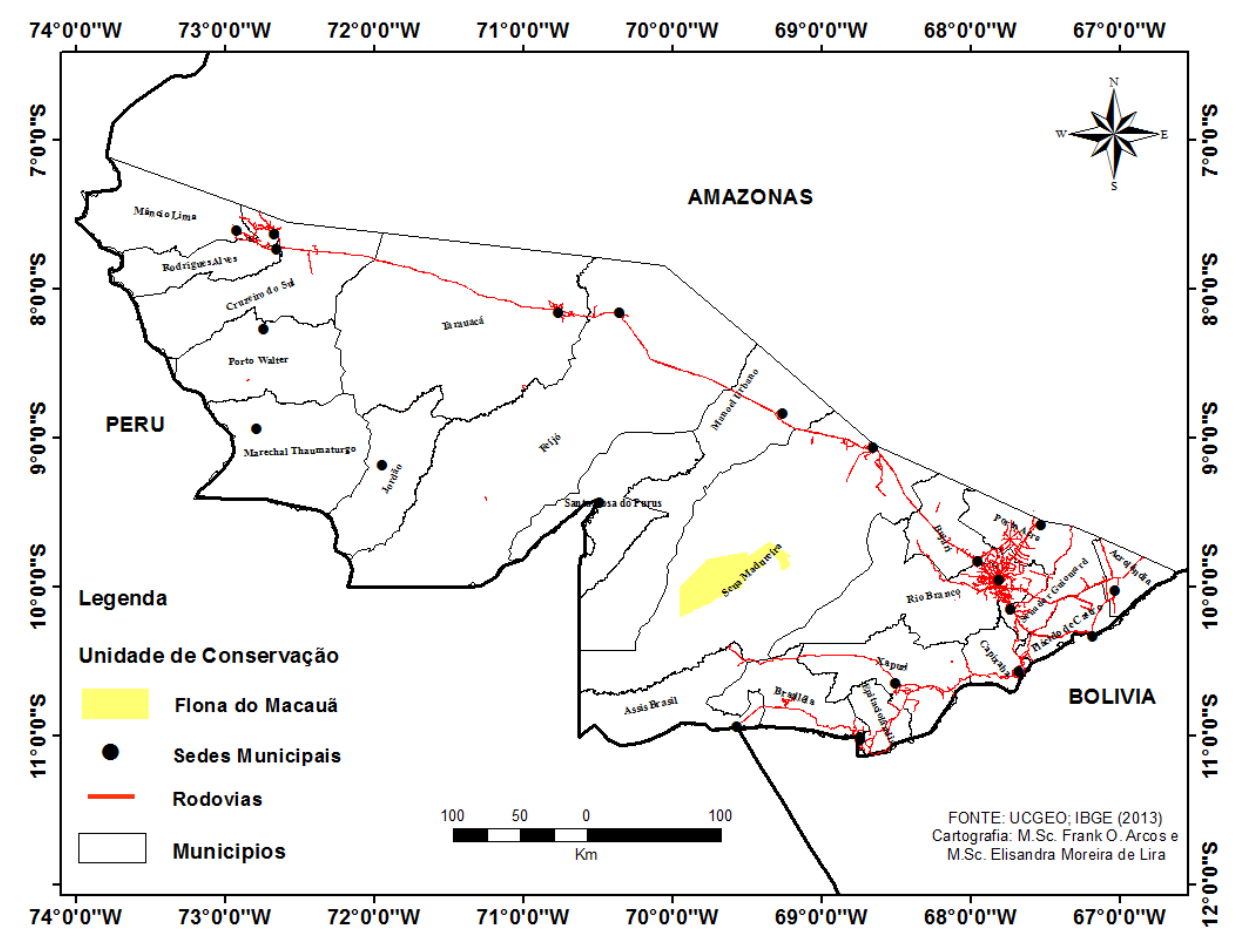

Mapa 7 Localização Geográfica da Floresta Nacional do Macauã-AC.

No ano de 2000, as Florestas Nacionais foram definidas pelos SNUC como: "uma área com cobertura florestal de espécies predominantemente nativas e tem como

${ }^{441}$ ICMBio. Plano de Manejo das Florestas Nacionais do Macauã e de São Francisco. v. 1. Diagnóstico e Caracterização. Sena Madureira-AC: ICMBio, 2009, 41-42.

${ }^{442}$ Id., p. 34-35. 
objetivo básico o uso múltiplo sustentável dos recursos florestais e a pesquisa científica, com ênfase em métodos para exploração sustentável de florestas nativas" ${ }^{443}$.

Entretanto, um estudo realizado em 2012, para identificar áreas de florestas estaduais, levando em consideração fatores como valor madeireiro, pressão antrópica, importância biológica, acessibilidade econômica, situação fundiária, entre outros, evidenciou que a área da Flona do Macauã é formada principalmente de formações florestais de baixo valor ${ }^{444}$, inviabilizando de certa forma o sucesso das atividades.

Com base no Plano de Manejo da Flona do Macauã, as atividades econômicas praticadas na unidade, giram em torno do extrativismo florestal, agricultura, pecuária e serviços (a produção de bens e serviços é destinada ao consumo local e ao mercado externo). Porém, o baixo investimento em capacitação e tecnologia limita a agregação de valor aos produtos e serviços, prevalecendo a produção de matéria-prima e mão-deobra baratos. Com o objetivo de mudar esta situação, instituições como o ICMBio, IBAMA, SEAPROF, FUNTAC e WWF, desenvolvem atualmente, trabalhos na Flona capacitando famílias, especialmente em técnicas de manejo de produtos florestais não madeireiros como o óleo de copaíba e a colheita de sementes ${ }^{445}$, visando aumentar sua renda familiar.

Passado um ano da criação da Flona do Macauã, em 1989, foi criado o Parque Nacional da Serra do Divisor (PNSD), que trataremos com maiores detalhes do cap. 4.

\subsection{Considerações Críticas sobre a Implantação de Unidades de Conservação no Acre}

Como vimos, a "Operação Amazônia" lançada pelos governos militares tinha como principais desafios a segurança nacional e a ocupação de espaços "vazios". Para a execução desta operação o governo federal criou órgãos e programas específicos.

Na opinião de Clara Pandolfo, esta operação visava desenvolver a Amazônia, ocupá-la, povoá-la e fortalecê-la economicamente, de modo a promover a sua definitiva

\footnotetext{
${ }^{443}$ Artigo $17^{\circ}$ da Lei $\mathbf{n}^{\mathbf{0}} \mathbf{9 . 9 8 5}$, de 18 de julho de 2000 .

${ }^{444}$ VERÍSSIMO, Adalberto; SOUZA Jr., Carlos, SALOMÃO, Rodney. Identificação de Áreas com Potencial para a criação de Florestas Estaduais no Estado do Acre. Relatório Final. Belém: IMAZON e Governo do Estado do Acre, 2002, p. 10,12.

${ }^{445}$ ICMBio, 2009, p. 119.
} 
integração à comunidade brasileira ${ }^{446}$. Entretanto, com bem pontuou Orlando Valverde, os vários incentivos fiscais e creditícios para a implantação de grandes projetos agropecuários na Amazônia, estimulou não só a destruição da floresta, mas também, a concentração de terra, a invasão de áreas indígenas, a expulsão de populações extrativistas, além de contribuir para o aumento dos conflitos sociais na região ${ }^{447}$.

Clando Yokomiso, em estudo publicado em 1989, intitulado "Incentivos financeiros na Amazônia: fatos, problemas e solução”, apresenta uma análise do desempenho dos projetos agropecuários implantados através dos incentivos fiscais do Fundo de Investimentos da Amazônia (FINAM). A análise foi realizada a partir dos projetos agropecuários que haviam sido aprovados (58\%). Dos 766 projetos aprovados (entre 1966 e 1988), 115 foram considerados implantados, ou seja 15\%; 63 foram cancelados (8\%) e, 33 não chegaram a ser iniciados (4\%), por isso, caducaram. A maior parte desses projetos (556), permaneceu em fase de implantação, por períodos que variavam de dez a vinte anos ${ }^{448}$.

Quanto aos projetos agropecuários implantados, segundo o estudo de Yokomiso, mostraram-se extremamente ineficazes. De um total de 90 projetos agropecuários e dois agroindustriais, apenas três apresentaram eficácia, no quesito rentabilidade.

Em outra pesquisa realizada por Suzan Hecht e Steve Schwartzmann ${ }^{449}$, intitulada "The Good, the Bad and the Ugly: Amazonian Extraction, Colonist Agriculture and Livestock in Comparative Perspective”, foram quantificados os custos e benefícios da criação de gado, da agricultura e do extrativismo, tendo como base o custo da recuperação ambiental local, usando como indicador apenas a recuperação do solo, excluindo os efeitos globais, como os causados pelas queimadas ou perda de germoplasma $^{450}$.

Neste estudo teve-se o seguinte resultado:

\footnotetext{
${ }^{446}$ PANDOLFO, Clara. A Amazônia, seu Grande Potencial de Recursos Naturais e Oportunidades de Industrialização. Boletim Geográfico, ano 30, n. 221. Rio de Janeiro: IBGE, março/abril de 1971, pp. 3595 , p. 35.

${ }^{447}$ VALVERDE, 1990, p. 84-85.

${ }^{448}$ YOKOMISO, 1989 apud VALVERDE, 1990, p. 85.

${ }^{449}$ HECHT, Suzan \& SCHWARTZMANN, Steve, 1988 apud VALVERDE, 1990, p. 85.

${ }^{450}$ Termo empregado para indicar o material genético que constitui a base física da herança que se transmite de uma geração para outra, através das células reprodutivas de uma espécie (MOURA, Maria da Cruz Chaves Lima at. al. Conservação in situ: cenário nacional e manejo. In: PEREIRA, Telma Nair Santana (editora técnica) Germoplasma: conservação, manejo e uso no melhoramento de plantas. Viçosa-MG: Arca, 2010, p. 42).
} 
Sem considerar o custo de recuperação do solo, analisando-se um projeto de 15 anos, a comparação entre as três atividades mostra que o extrativismo dá lucros médios anuais cinco vezes maiores do que os da agricultura e 15 vezes maiores do que os da pecuária. Introduzindo-se os custos de recuperação dos solos, para que a terra possa novamente passar a produzir, tem-se, em 20 anos, resultados negativos (de US\$ 28.000 a US\$ 55.000 para a agricultura e de US\$ 60.000 a US\$ 100.000 para a pecuária). Os únicos resultados positivos (entre US\$30.460 e US\$ 50.000) são os do extrativismo vegetal, dada a ausência de custos de recuperação, em função da reposição natural dos recursos extraídos ${ }^{451}$.

Os resultados dessas pesquisas, segundo Valverde, vêm comprovar a ineficácia da política de estímulo à agropecuária para a região amazônica, depois de vinte anos de vigência, ou seja, de 1970 a $1990^{452}$.

De acordo com Warren Dean, a redução irresponsável das florestas da bacia amazônica nos anos 1970, suscitou o alarme e o escárnio internacional. Para o autor, a Floresta Amazônica provocara especial alarme e presságio, quando comparada aos estudos históricos que mostram as terríveis consequências da destruição da Mata Atlântica ${ }^{453}$.

Realmente, a destruição das florestas na região (em conjunto com a morte de Chico Mendes, em 1988), teve grande repercussão mundial e levou à realização no Brasil da Conferência das Nações Unidas sobre Meio Ambiente e Desenvolvimento, ocorrida no Rio de Janeiro em junho de 1992, como já mencionado no Cap. 1.

Como vimos, na opinião de Schmink \& Wood, a luta dos seringueiros pelo controle do desmatamento no Acre, através dos "empates", não deve ser considerada uma ação ambiental, mas agrária. No entanto, os seringueiros, na tentativa de se protegerem dos fazendeiros, enalteceram a sabedoria da cultura tradicional e as virtudes da conservação da floresta. Fazendo isto, estabeleceram uma afinidade com o movimento global. Segundo estes autores, “A ascensão dos critérios ambientais no Brasil e no mundo alterou profundamente o conteúdo do debate sobre o destino da Amazônia e dos méritos do "desenvolvimento" em geral" 454 .

Segundo Schmink \& Wood, daí resultou o chamado "discurso verde", gerado de um processo pelo qual os atores sociais passaram a reformular seus interesses em termos ambientais ${ }^{455}$. Eles apresentam como exemplo dramático desse "esverdeamento" de discurso,

\footnotetext{
${ }^{451}$ HECHT \& SCHWARTZMANN, 1988 apud VALVERDE, 1990, p. 85.

${ }^{452}$ VALVERDE, 1990, p. 85.

${ }^{453}$ DEAN, 1996, p. 380.

${ }^{454}$ SCHMINK \& WOOD, 2012, p. 54-55.

${ }^{455}$ Id., p. 55.
} 
[...] a forma como alguns seringueiros no Estado do Acre, ao defenderem seus territórios contra a intrusão de fazendeiros determinados a converter florestas em pastos, se autodefenderam como guardiões da floresta. Um rótulo que emergiu das alianças por eles forjadas com os militantes nacionais e internacionais, cuja missão era defender a floresta. Como Chico Mendes bem lembrou numa entrevista pouco antes de sua morte, "até recentemente, a palavra 'ambiente' nem mesmo existia em nosso vocabulário"

Vários anos depois, em 1990, outro líder seringueiro, Osmarino Amâncio Rodrigues, questionou a utilidade política do discurso ambiental que os seringueiros tinham adotado:

Ele temia que uma ênfase exclusiva em temas ecológicos trouxesse o risco de desviar a atenção do que considerava como foco prioritário - reforma agrária. Se a defesa do ambiente é divorciada da justiça social, argumentava o líder, o sindicato dos seringueiros corria o risco de endossar o que ele chamava de um "ambientalismo vazio"457.

Com discurso "esverdeado" ou não, este movimento contribuiu para que o governo federal tomasse iniciativas para contrabalancear os efeitos do desmatamento. Neste contexto, foram criadas várias unidades de conservação na Amazônia. Como vimos, mesmo durante o período militar (de 1974 a 1984), a região protegeu quase 106.000 km² com a implantação de dezenove unidades de conservação.

No Estado do Acre, palco dos conflitos entre seringueiros e os "novos" donos da terra, foram criadas três unidades de conservação na década de 1980. Também, devido às conquistas dos movimentos sociais dos seringueiros, foram estabelecidas, na década de 1990, as primeiras Reservas Extrativistas do Brasil. Com base nos levantamentos de Lira e Nascimento, até 2012, o Acre possuía dezessete unidades de conservação, três de proteção integral e quatorze de uso sustentável. Cobrindo juntas, cerca de $51.982,73 \mathrm{~km}^{2}$, o correspondente a 31,65\% do território, sem contar as terras indígenas, que somavam $13,1 \%$ das terras do Estado ${ }^{458}$.

\footnotetext{
${ }^{456}$ SCHMINK \& WOOD, 2012, p. 55.

${ }^{457}$ RODRIGUES, 1990 apud SCHMINK \& WOOD, 2012, p. 55.

${ }^{458}$ LIRA, Elisandra Moreira de; NASCIMENTO, Ivam Castro do. Sistema Estadual de Áreas Naturais Protegidas do Estado do Acre: bases para a sustentabilidade ambiental. Revista Brasileira de Ciências da Amazônia, v. 1. n. 1, p. 99-103, Rolim de Moura-RO, 2012.
} 


\section{CAPÍTULO 4}

\section{A Implantação do Parque Nacional da Serra do Divisor no Acre: 1976 a 1998}

\subsection{Localização Geográfica do Parque Nacional da Serra do Divisor - PNSD}

O Parque Nacional da Serra do Divisor (PNSD) é uma Unidade de Conservação de Proteção Integral, ou seja, de uso indireto, a segunda unidade desta categoria no Acre ${ }^{459}$. Criado pelo Decreto federal n. 97.839 de $1989^{460}$, protege uma área de 843.012,28 hectares $\left(8.430,12 \mathrm{~km}^{2}\right)^{461}$, com objetivos baseados na preservação dos ecossistemas e na realização de pesquisas científicas. Assim como todos os parques, apresenta restrições à presença humana, a não ser para fins educativos, e ou recreativos, e está sob gerência do governo federal, através do Instituto Chico Mendes de Conservação da Biodiversidade (ICMBio).

Seu nome originou-se de uma importante característica geomorfológica que existe na área, a região divortium aquarum (divisor de águas) das bacias hidrográficas do Médio Vale do Rio Ucayali, no Peru e do Alto Vale do Rio Juruá, Acre/Brasil ${ }^{462}$.

Está localizado no extremo oeste do Estado do Acre, nas seguintes latitudes e

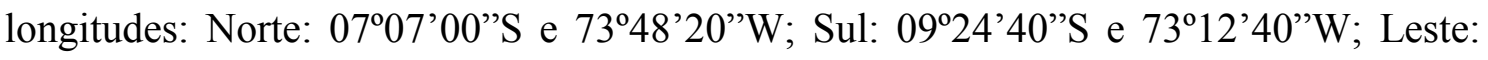
0908'40”S e 7240'00”W; Oeste: 07³2’40”S e 7359’20”W. A área do parque abrange terras dos municípios de Cruzeiro do Sul, Mâncio Lima, Rodrigues Alves, Porto Walter e Marechal Thaumaturgo, municípios que fazem parte da microrregião de Cruzeiro do Sul. O PNDS ainda faz fronteira com o Peru em toda sua porção ocidental.

Partindo da cidade de Cruzeiro do Sul, a principal via de acesso ao PNSD (no período chuvoso - novembro/abril), é feita por via fluvial, chegando-se ao Setor Norte do Parque através dos rios Môa e, ao Setor Sul, pelo rio Juruá. No período de chuvas é possível a utilização de canoas, baleeiras ou batelões, com capacidade para até oito toneladas (com motor de centro ou de rabeta), que levam em média doze horas para

\footnotetext{
459 A primeira trata-se da Estação Ecológica Rio Acre.

460 BRASIL. Decreto no 97.839, de 16 de junho de 1989. Cria o Parque Nacional da Serra do Divisor. Brasília: 1989.

461 SOS AMAZÔNIA. Plano de Manejo Parque Nacional da Serra do Divisor Acre - Brasil. Rio Branco: SOS AMAZÔNIA, IBAMA, The Nature Conservancy, 1998, p. 34.

462 Id., p. 42.
} 
atingir a confluência do rio Môa com o Azul e cerca de quinze horas para chegar à confluência dos rios Juruá/Juruá-Mirim. Mas, ao se utilizar embarcações tipo lanchas, conhecidas localmente de "voadeiras", o tempo reduz-se pela metade ${ }^{463}$.

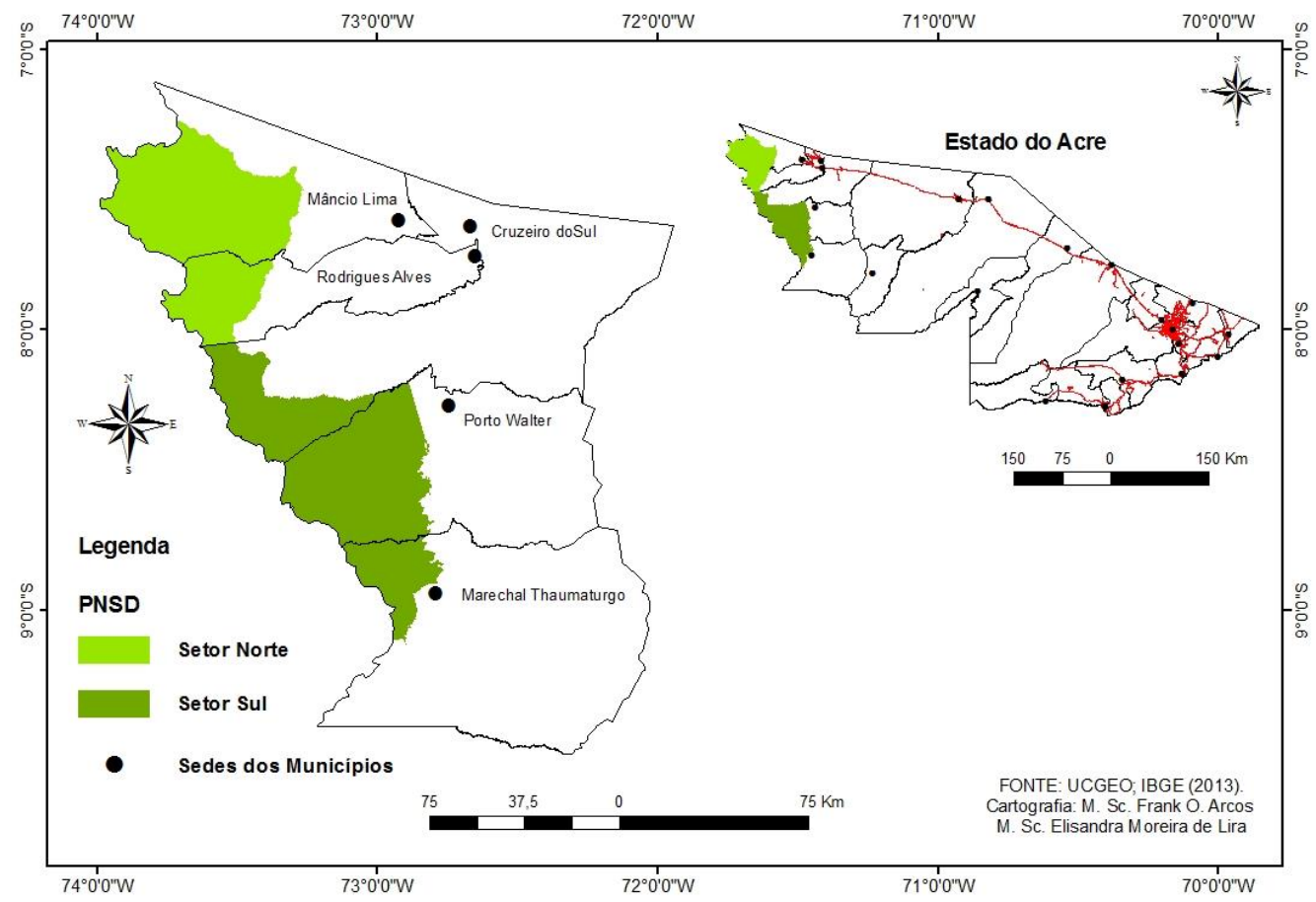

Mapa 8 Localização Geográfica do Parque Nacional da Serra do Divisor - AC.

Com a diminuição do nível de água dos rios, no período de estiagem, troncos de árvores ficam encalhados em seus leitos, permitindo apenas o fluxo de pequenas embarcações, canoas ou botes de alumínio (com capacidade para carga de no máximo duas toneladas). Neste período, o tempo de deslocamento até o Parque pode chegar a vinte e quatro horas para se chegar Setor Norte, e trintas horas para o Setor Sul ${ }^{464}$.

Neste capítulo será analisado o processo pelo qual esta área, como vemos, de difícil acesso e na fronteira extrema oeste do Brasil, foi escolhida como adequada à implantação de uma unidade de conservação e, por fim, criado, em 1989, o PNSD.

${ }^{463}$ SOS AMAZÔNIA, 1998, p. 6 (Encarte 1).

${ }^{464}$ Id., p. 6-7 (Encarte 1). 


\subsection{Os Primeiros Estudos para Implantação de Unidades de Conservação no sudoeste da Amazônia}

Na esteira do II Plano Nacional de Desenvolvimento, nos anos 1970, proliferaram estudos que visavam contribuir para a implantação de medidas para conservação da natureza na Amazônia. Consideramos que estes estudos foram fundamentais para as políticas federais de criação de unidades de conservação na Amazônia- entre elas o PNSD- nas décadas seguintes.

\subsubsection{O II PND e as questões ambientais}

O II PND (1975-1979) incluía como objetivo nacional atingir "o desenvolvimento sem deterioração da qualidade da vida, e, em particular, sem devastação do patrimônio de recursos naturais do País" ${ }^{465}$. Entretanto, no âmbito da "Estratégia Agropecuária" contida no Plano, ficou destacado que, no quadro mundial, o Brasil era um dos poucos países com grande disponibilidade de espaço, e a ocupação de novas áreas era promissora para a expansão da agropecuária. Em especial, o Plano enfatizava a existência de terras relativamente férteis para deslocamento da fronteira agrícola no sentido Centro-Oeste e Amazônia ${ }^{466}$, modelo de ocupação definido como uma estratégia de integração nacional.

Olhando à distância, o Plano se mostra bastante contraditório, já que parecenos impossível ignorar a possibilidade de uma grande devastação da floresta nestas regiões, através da derrubada e queimada. Entretanto, o Plano sugeria que, para a ocupação dessas novas áreas e para a expansão da fronteira agropecuária, seria importante utilizar diretrizes de "caráter conservacionista, evitando o uso indiscriminado do fogo, no preparo de áreas, e utilizando práticas de rotação de culturas e descanso do solo, de modo a manter a produtividade das terras em níveis elevados" 467.

A análise do II PND sugere assim que a ideia era adotar uma política de desenvolvimento de recursos florestais e uso racional dos solos da Amazônia, para

\footnotetext{
${ }^{465}$ BRASIL. II Plano Nacional de Desenvolvimento (1975-1979). Brasília, 1974, p. 15

466 Id., p. 27.

467 Ibid., p. 29.
} 
transformar a exploração madeireira em uma atividade planejada, institucionalizada e permanente. E que, para tanto, seria adotado o sistema de Florestas de Rendimento, que condicionava os projetos às exigências de regeneração conduzida e reflorestamento, buscando evitar o processo de devastação já presente na região ${ }^{468}$.

Além disso, o II PND sugeriu, por antecipação, que fossem definidas as áreas que seriam destinadas à criação de unidades de conservação, como os "... Parques $e$ Florestas Nacionais, Reservas Biológicas e Parques de Caça"469.

Como já mencionado no capítulo 3, no início da década de 1970, o Presidente Médici, visando acelerar o processo de ocupação da região amazônica lançou o Programa de Integração Nacional (PIN). Esse programa tinha como metas a efetiva incorporação nacional da região amazônica no contexto de desenvolvimento econômico e social. Foram construídas grandes rodovias para facilitar o fluxo de mercadorias e pessoas, fortalecendo a criação de novos polos de atividades agropecuárias e de mineração.

Com investimentos oriundos do PIN e de outros programas, em 1974 foi aprovado o Programa de Polos Agropecuários e Agrominerais da Amazônia (POLAMAZÔNIA). Este estava pautado no aproveitamento integrado das potencialidades agropecuárias, agroindústrias, florestais e minerais, através da implantação de quinze polos de desenvolvimento, em áreas prioritárias da Amazônia. E para cada polo deveria ser elaborado um Plano de Desenvolvimento Integrado (PDI) ${ }^{470}$.

No artigo $5^{\circ}$, do Decreto de criação do POLAMAZÔNIA, ficou definido que os PDI's deveriam contemplar além do zoneamento adequado do uso dos recursos naturais, a "destinação de áreas para reservas florestais e biológicas, parques nacionais e reservas indígenas" ${ }^{\prime 471}$.

Já observamos no capítulo anterior, que os programas governamentais impulsionaram o processo de ocupação da Amazônia, atraindo várias frentes pioneiras para áreas até então "intocadas". Esse modelo de ocupação a qualquer custo gerou preocupações nos meios científicos e em diversos segmentos da população brasileira, com questionamentos sobre a destruição dos recursos naturais e a necessidade de proteger amostras de ecossistemas.

\footnotetext{
468 Ibid., p. 29.

${ }^{469}$ Ibid., p.51.

470 Áreas consideradas prioritárias: Xingu-Araguaia, Carajá, Araguaia-Tocantins, Trobetas, Altamira, Maranhense, Rondônia, Acre, Juruá Solimões, Roraima, Tapajós, Amapá, Juruena, Aripuaña e Marajó.

471 BRASIL. Decreto n. 74.607, de 25 de setembro de 1974. Dispõe sobre a criação do Programa de Pólos Agroflorestais e Agrominerais da Amazônia (POLAMAZÔNIA). Brasília, 1974.
} 
Consideramos que as observações contidas no II PND e também no POLAMAZÔNIA procuravam responder a estas questões. Também, na esteira do Plano Desenvolvimento e do Programa de Polos, diversas organizações e instituições apresentaram propostas objetivando a criação de unidades de conservação na região ${ }^{472}$.

Analisaremos a seguir três propostas que, na nossa opinião, foram fundamentais para o projeto de criação do PNSD.

\subsubsection{O relatório do IBDF: “Uma Análise de Prioridade para a Conservação da} Natureza na Amazônia” de 1976

Com base nas recomendações do II PND (1975-79), o IBDF publicou, em 1976, um relatório intitulado "Uma Análise de Prioridade para a Conservação da Natureza na Amazônia”, que tinha por objetivo a definição de um programa geral para a conservação da natureza na região, incluindo a identificação, em bases científicas, de áreas chaves a serem estudadas para sua futura proteção ${ }^{473}$. Só para a Amazônia brasileira, o relatório previa a proteção de 17.500 .000 hectares através da criação de novos Parques Nacionais ou Reservas Biológicas ${ }^{474}$.

O documento foi estruturado com os seguintes itens: Introdução, Alguns Problemas, Objetivos, Diversidade na Amazônia, Preservação do Habitat: uma necessidade básica, Requisitos de Tamanho, Unidades de Conservação Existentes e Planejadas, Vegetação, Refúgios do Pleistoceno, Polos de Desenvolvimento da Amazônia - POLAMAZÔNIA, Prioridades aparentes para Unidades de Conservação da Natureza na Região Amazônica, O Plano do Sistema de Parques Nacionais, Conclusões, e Recomendações. A elaboração ficou a cargo dos pesquisadores: Gary B. Wetterberg, Engenheiro Florestal, especialista em manejo de áreas silvestre (integrante do Projeto de Desenvolvimento e Pesquisa Florestal -PNUD/FAO/IBDF/BRA); Maria Tereza Jórge Pádua, Engenheira Agrônoma (Diretora da Divisão de Proteção da Natureza - IBDF); Celso Soares de Castro, Engenheiro Agrônomo (Diretor do Departamento de Parques Nacionais e Reservas Equivalentes - IBDF); e José Manuel Carvalho de Vasconcellos, Planejador Ambiental e Arquiteta Paisagista (Assessor do Departamento de Parques Nacionais e Reservas - IBDF) ${ }^{475}$.

\footnotetext{
${ }^{472}$ QUINTÃO, 1983, p. 22.

${ }^{473}$ Id., p. 22.

${ }^{474}$ WETTERBERG, 1977 apud PÁDUA e PORTO, 1979, p. 20.

${ }^{475}$ WETTERBERG, et. al., 1976.
} 
O relatório identificava alguns problemas que impediam a definição de possíveis áreas de conservação na região amazônica. Primeiramente o documento destaca a falta de conhecimento sobre esta vasta região; em segundo lugar, destaca que muitas das publicações científicas existentes não chegavam aos indivíduos em posições políticas ou administrativas, para que pudessem ser usadas no desenvolvimento de políticas de conservação; também que os critérios para selecionar Parques Nacionais e Reservas Equivalentes, dificilmente se aplicavam à Amazônia já que, para a região, o objetivo principal seria a manutenção da diversidade. O conceito de Reserva Biológica, por exemplo deveria ter maior representação. Por último, declara que na região, tais áreas eram, na maioria das vezes, criadas de uma forma ad hoc, em resposta a pressões locais, expedientes políticos, ou situações oportunistas ${ }^{476}$. Para Dourojeanni, a maioria das áreas escolhidas para a implantação das unidades de conservação do bioma amazônico, foram selecionadas por razões estéticas ou políticas ${ }^{477}$.

Nesse sentido, o relatório faz uma tentativa de analisar alguns dos problemas apontados acima, e tornar essas análises, de domínio público, para uma revisão crítica e "feedback". Dentre os objetivos propostos destacavam-se:

a) Sintetizar e comparar os trabalhos publicados por vários especialistas da Amazônia, para que possam ser tentativamente identificadas prioridades biologicamente significantes em conservação da natureza;

b) Identificar e localizar as unidades de conservação existentes e planejadas na Amazônia;

c) Analisar potenciais compatibilidades ou incompatibilidades entre os programas Brasileiros do POLAMAZÔNIA e a preservação de áreas biologicamente significantes;

d) Propor um programa de conservação da natureza na Amazônia que desse a devida consideração à diversidade da região, permitisse a identificação de áreas prioritárias a serem preservadas, e que fosse suficientemente flexível para adaptar-se a futuras descobertas científicas;

e) Permitir uma ação mais efetiva dos organismos públicos responsáveis por Parques Nacionais e Reservas Equivalentes, pela qual uma política de conservação para Amazônia pudesse ser efetivamente perseguida;

f) Contribuir para a execução do seu Plano do Sistema de Parques Nacionais ${ }^{478}$.

Para apontar as regiões com potencial para a implantação de Unidades de Conservação, o relatório utilizou como metodologia informações de várias fontes relativas às regiões fitogeográficas; unidades de conservação existentes e planejadas; formações vegetais; refúgios do Pleistoceno, baseados em pássaros, lagartos, evidência

\footnotetext{
${ }^{476}$ Id., p. 2-3.

${ }^{477}$ DOURAJEANNI, 1975 apud WETTERBERG, et. al., 1976, p. 3.

${ }^{478}$ Id., p. 4.
} 
botânica e borboletas; e os Polos de Desenvolvimento da Amazônia ${ }^{479}$. Estas informações foram transferidas para cartas transparentes na mesma escala, permitindo assim uma análise visual das relações dos vários fatores. Todavia, mesmo compilando os estudos mais completos existentes, a escala utilizada só permitiu dados $\operatorname{aproximados}^{480}$.

As regiões fitogeográficas ${ }^{481}$ foram definidas seguindo os padrões definidos por Prance (1976) $)^{482}$ e Pires $(1974)^{483}$ que identificaram diversos tipos fisionômicos da vegetação Amazônica. O relatório utilizou a área delimitada por Prance, que consistia em cerca de $6.250 .000 \mathrm{~km}^{2}$, definindo assim sete regiões ou feições ${ }^{484}: 1$ - Costa Atlântica, 2 - Jari-Trombetas, 3 - Xingú-Madeira, 4a - Roraima, 4b - Manaus, 5 - Alto Rio Negro, 6 - Solimões-Amazonas, e 7 - Sudoeste.

Das unidades de conservação já existentes o relatório considerou vinte e duas áreas, sendo nove em território brasileiro, uma na Colômbia, uma no Equador, uma na Guiana, três no Peru, seis no Suriname e uma na Venezuela. Quanto às unidades planejadas foram indicadas cinquenta nove, a maioria no Brasil (51 unidades) ${ }^{485}$.

\footnotetext{
${ }^{479}$ Ibid., p. 5-23.

${ }^{480}$ PÁDUA e PORTO, 1979, p. 20.

${ }^{481}$ São regiões definidas de acordo com a flora predominante.

482 Ghillean Tolmie Prance é um botânico, nasceu em 13 de julho de 1937, em Brandeston, Suffolk, Inglaterra. Trabalhou de 1963 a 1988 no Jardim Botânico de Nova York, como Diretor do Instituto de Botânica Econômica. Durante sua carreira no Jardim Botânico, ele realizou extensos trabalhos de campo na Amazônia brasileira, onde atuou por mais tempo. Depois foi diretor do Royal Botanic Gardens, onde atuou até 1999 (SIR Ghillean Prance 1937. Disponível em: http://www.prancefamily.co.uk/Sir Ghillean Prance.html Acesso em 06 jan. 2015). Em 1976 publicou o trabalho "The phytogeographic subdivions of Amazonia and their consequencis on the selection of biological reservas", em Bronx, pelo Jardim Botânico de Nova York, com 38 páginas.

483 João Murça Pires (1917-1994), nasceu Bariri, São Paulo. Fez o Curso de Agronomia pela Escola Superior de Agricultua Luiz de Queiroz/ESALQ/USP de Piracicaba, em 1942 e recebeu o título de Doutor em Ecologia Florestal em 1942 pela mesma instituição. Ele um taxonomista vegetal e fitogeográfico renomado, orientado inicialmente por Adolpho Ducke, se tornou um expert da taxonomia da flora amazônica. Suas coleções botânicas estão disponíveis principalmente nos herbários do Centro de Pesquisa Agroflorestal da Amazônia Oriental/CPATU, Museu Paraense Emílio Goeldi, Universidade de Brasília, Jardim Botânico do Rio de Janeiro, New Yok Botanical Garden/EUA e Smithsonian Institution/EUA. Seus trabalhos sobre vegetação, publicado entre 1973 e 1989 são aceitos pela maioria dos botânicos da região e do exterior, inclusive pelo próprio Projeto RADAMBRASIL (LISBOA, Pedro L. B. e ALMEIDA, Samuel Soares de. Vida e Obra de João Murça Reis Pires - 1917-1994. Acta bot. bras., v. 9, n. 5, p. 303-314, 1995). Em 1974 publicou o artigo "Tipos de vegetação da Amazônia" na revista Brasil Florestal, v. 5, n. 17, p. 48-58.

${ }^{484}$ Embora a maioria da área esteja dentro do Brasil, partes da Bolívia, Colômbia, Equador, Guiana Francesa, Guiana, Peru, Suriname e Venezuela também estão incluídas.
}

${ }^{485}$ WETTERBERG, et. al., 1976, p.13. 


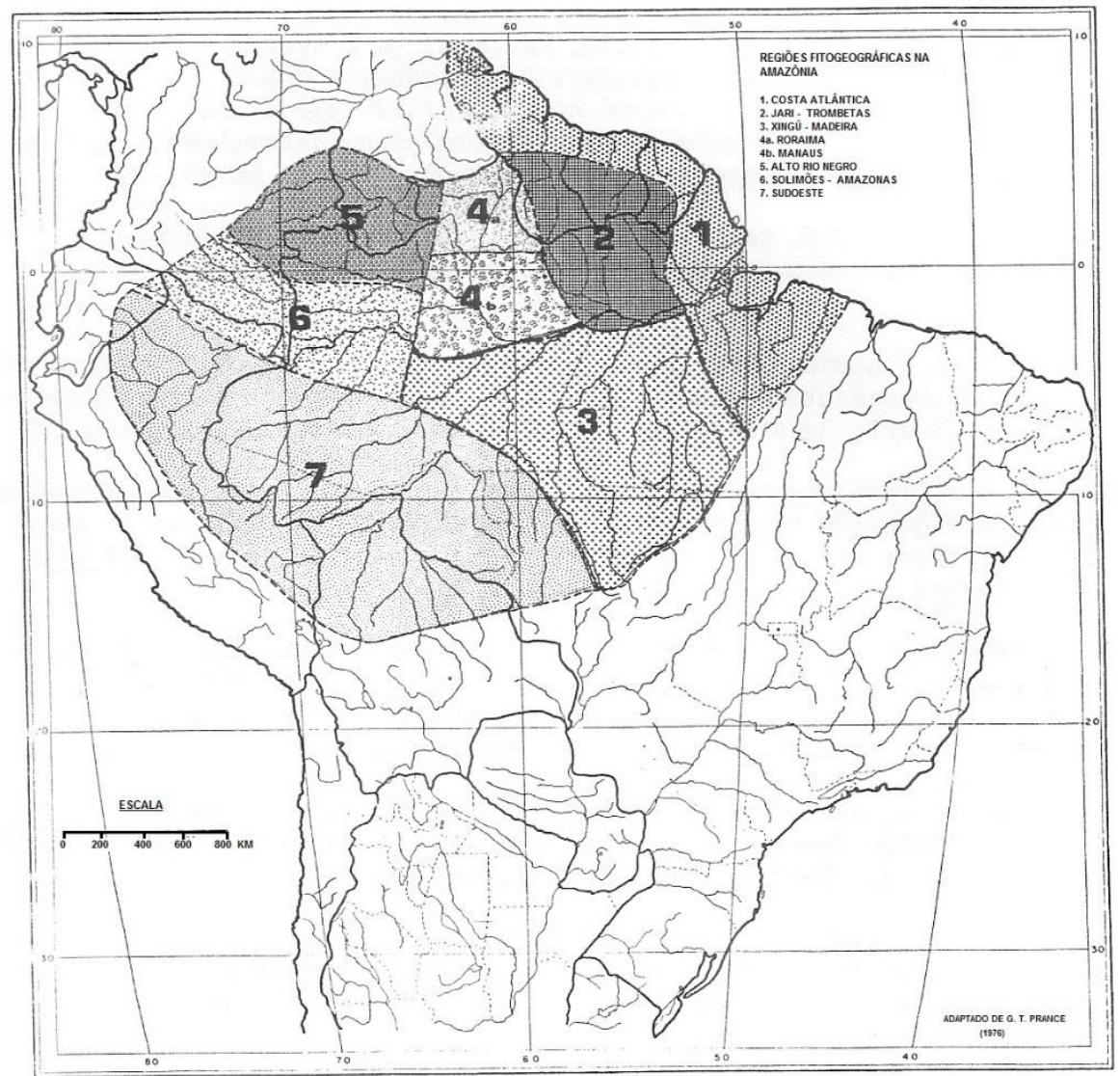

Figura 7 As Regiões Fitogeográficas na Amazônia classificadas por Prance (1976) e Pires (1974). Fonte: WETTERBERG at. al., 1976, p. 53.

Quando feita uma análise dos sistemas de manejo dos diferentes tipos de unidades de conservação existentes e propostos, dentro ou na adjacência dos limites das regiões fitogeográficas da Amazônia (indicadas por Prance, 1976), os parques e reservas citados não eram necessariamente representativos das regiões nas quais estavam localizados, demonstrando prováveis lacunas na cobertura. A região fitogeográfica Solimões-Amazonas, foi um exemplo de cobertura inexistente, mas todas as unidades propostas (Parque Nacional Auati-Paraná, Estação Ecológca Japurá-Solimões no Brasil; Parque Nacional Yasuni no Equador; e o Parque Nacional do Loreto, no Peru), estão situadas nesta região ${ }^{486}$. Para nosso estudo, vale ressaltar que, na região fitogeográfica do Sudoeste da Amazônia, uma Reserva Biológica foi planejada para o Estado do Acre, denominada Cruzeiro do Sul.

Outra análise da vegetação foi realizada à luz das províncias biogeográficas do mundo, propostas pela União Internacional para a Conservação da Natureza e Recursos

${ }^{486}$ Id., p.15. 
Naturais - IUCN, publicado por Udvardy ${ }^{487}$, em 1975. De acordo com os critérios de Udvardy, a Amazônia faria parte do Domínio Neotropical, sendo na sua maioria formada pelas Províncias da “Guyanan, Amazônian e Maderian”488. Pelo relatório, embora cerca de $90 \%$ da Amazônia consistisse de Floresta Tropical Úmida, os demais tipos de vegetação contribuíam para a diversidade biológica da área e incluíam: Mata de Cipó, Campinas Altas, Mata Seca de Transição, Mangue, Mata de Igapó, Mata de Várzea, Cerrado, Campos de Terra Firme e Campos de Várzea ${ }^{489}$. É importante destacar que segundo o próprio Relatório, a análise dos sistemas de manejo existentes e previstos nas formações vegetais, como no caso das regiões fitogeográficas, não eram necessariamente representativos das formações nos quais estavam localizados, demonstrando também prováveis lacunas de cobertura ${ }^{490}$.

Os prováveis Refúgios do pleistoceno na Amazônia, nas Florestas de Terra Firme, foram sugeridos por Haffer $(1969,1974)^{491}$; Vanzolini $(1970)^{492}$, Vanzolini e Willians (1970) ${ }^{493}$; Prance $(1973)^{494}$; Brown $(1975,1976)^{495}$; e Wing $(1973)^{496}$. Tais

\footnotetext{
${ }^{487}$ Miklos Dezso Fernc Udvardy (1919-1998) nasceu em Debrecen, Hungria. Recebeu o título de doutor em Biologia pela Universidade de Debrecen em 1942. Inicialmente trabalhou na Estação Biológica Tihanyi em Lake Balaton, oeste da Hungria. Em 1948 deixou a Hungria para residir Uppsala na Suécia, onde foi curador de invertebrados marinhos no Museu Sueco de História Natural, em Estocolmo. Depois de casado migrou para o Canadá, em 1952 foi nomeado Professor Assistente do Departamento de Zoologia pela University of British Columbia, em Vancouver "A Classification of the biogeographical provinces of the world", publicada pela UICN Occasional Paper, n. 18, Morges, Switzerland, com 48 páginas.

${ }^{488}$ WETTERBERG, et. al., 1976, p.16.

${ }^{489}$ Adicionalmente, Prance indicou uma floresta de bambu, descoberta no Estado do Acre, em 1976, mas que ainda estava cartografada (WETTERBERG, et. al., 1976, p.18).

${ }^{490}$ Id., p.18.

${ }^{491}$ HAFFER, Jugem. Speciation in Amazonian forest birds, Science, v. 165, n. 3889, p. 131-137, jul. 1969.
}

Avian speciation in tropical South America. Nuttall Ornithological Club. Museum of Comparative Zoology. Harvard University Cambridge, Mass. USA (390p.), 1974.

${ }^{492}$ VANZOLINI, Paulo Emílio. Zoologia sistemática, geografia e a origem das espécies. São Paulo: Universidade de São Paulo (Série Teses e Monografias IG, n. 3, 56p).

${ }^{493}$ VANZOLINI, Paulo Emílio and WILLIAMS, Ernest E. South American anoles: the geographic differentation and evolution of the Anolis chrysolepis species group (Sauri, Iguanidae), Arq. Zool. v. 19, p. 1-240, São Paulo.

${ }^{494}$ PRANCE, Ghillean Tolmie. Phytogeographic support for the theory of Pleistocene forest refuges in the Amazon Basin, based on evidence fron Dichapetalaceae and Lecythidaceae. Acta Amazonica,v. 3, n. 3, p. 5-28, INPA/CNPq., 1973.

${ }^{495}$ Brown, K. S. Jr. Geographical patterns of evolution in neotropical lepidóptera. Sustematcs and Derivation of Known and new heliconiini (Nymphalidae: Nymphalinne), Jor. Ent.. (B), v. 44, n. 3, p. 201-242, 1975.

Geographical patterns of evolution in neotropical Lepidóptera. (Nymphalidae: Ithomiinae \& Nymphalianae-Heliconiini), Contribuição n. 19, Prog. de Ecologia. Inst. De Biologia. Universidade Estadual de Campinas -SP, Brazil. In press. Orig. manuscript, 31p., 1976.

${ }^{496}$ WING, H. Races of Drosophila willistoni sibling species: probable origin in quaternary forest refuges of. S. America. Genetics, v. 74, p. 297-298 (Suppl.), 1973. 
refúgios, principalmente onde eles se sobrepunham ou se juntavam, foram considerados áreas que possuíam ou poderiam possuir uma alta probabilidade de espécies endêmicas.

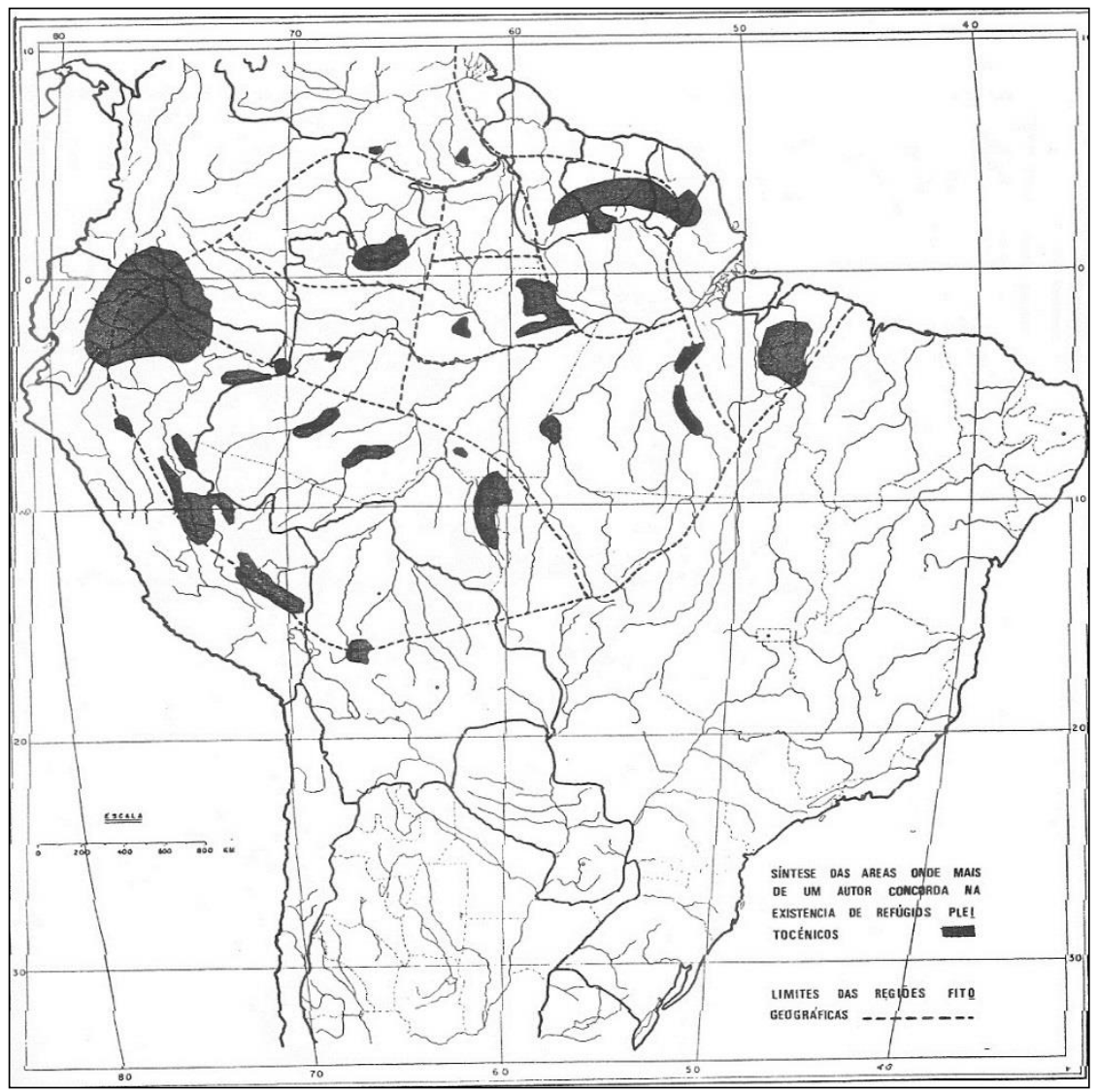

Figura 8: Prováveis Refúgios do Pleistoceno na Amazônia Fonte: WETTERBERG, at. al., 1976, p.60.

Ao sobrepor alguns mapas com diferentes espécies de animais, por exemplo, gerou-se um mapa que mostra áreas gerais onde dois ou mais autores concordavam na existência de refúgios do Pleistoceno. Embora, segundo o relatório, esta informação estivesse em uma escala grosseira e não levasse em consideração possíveis alterações ambientais recentes, podia se ter uma ideia das áreas potencialmente importantes biologicamente, devendo, portanto, serem consideradas na criação de um sistema de unidades de conservação na Amazônia ${ }^{497}$.

O Relatório também analisou os quinze Polos de Desenvolvimento da Amazônia, sugeridos pelo POLAMAZÔNIA, que fazia a indicação de áreas de desenvolvimento prioritárias (Xingu-Araguaia, Carajá, Araguaia-Tocantins, Trombetas, Altamira, Maranhense, Rondônia, Acre, Juruá Solimões, Roraima, Tapajós, Amapá,

${ }^{497}$ WETTERBERG, et. al., 1976, p.20. 
Juruena, Aripuaña e Marajó). Ao comparar as regiões fitogeografias e as áreas de mais alta probabilidade de endemismo, indicadas pelos refúgios do Pleistoceno, com os polos de desenvolvimento prioritário, apenas três deles (Altamira, Aripuaña e Juruá-Solimões) demonstraram abrigar áreas de alta probabilidade de espécies endêmicas.

Levando em consideração as dimensões analisadas (regiões fitogeográficas; unidades de conservação existentes e planejadas; formações vegetais; refúgios do Pleistoceno; e os Polos de Desenvolvimento), o relatório do IBDF finalizava com a indicação de áreas para a criação de unidades de conservação da natureza na região amazônica, com três níveis de prioridade.

As áreas definidas como de primeira prioridade, foram aquelas que mais de um autor considerou como refúgio do Pleistoceno, embora essas áreas não representassem necessariamente as áreas de maior riqueza e diversidade de flora e fauna na época. A segunda prioridade ficou para as áreas que mais provavelmente representavam diversas formações vegetais e talvez um refúgio Pleistocênico ao mesmo tempo. Enquanto as áreas de terceira prioridade incluíam todos os outros parques e reservas já propostos anteriormente ao Relatório ${ }^{498}$.

Os critérios estabelecidos pelo relatório deram ênfase à Floresta Amazônica de "Terra Firme" que, segundo os estudos feitos, constituía 90\% da bacia. Entretanto, a floresta de terras baixas, e áreas não florestadas, mesmo encontrando-se dentro das categorias de segunda ou terceiras prioridades, não eram menos importantes para o objetivo de preservar amostras representativas, devendo ser consideradas em suas especificidades por cientistas qualificados ${ }^{499}$. Também é importante ressaltar que, as áreas qualificadas como de segunda prioridade, devido aos tipos de vegetação, foram omitidas na porção oeste da Amazônia, visto que as formações vegetais indicadas nas análises foram baseadas em trabalhos feitos, especialmente, na porção leste da região.

A região da Serra do Divisor (AC), ponto mais ocidental do Brasil, ficou classificada como de primeira prioridade, localizada na sétima região Fitogeográfica, a Sudoeste, na qual Prance (1973) e Haffer (1974) indicaram refúgios que se sobrepunham, próximo das cabeceiras do Rio Tapiche e outros pequenos tributários do Rio Ucayali, no leste do Peru.

Não podemos deixar de registrar que o relatório "Uma Analise de Prioridades em Conservação na Natureza na Amazônia”, produzido pelo IBDF, constituiu-se em um

498 Id., p. 24.

${ }^{499}$ Ibid., p. 24-25. 
estudo com bases teóricas, mas, com uma escala considerada grosseira pelo próprio relatório, com grandes extrapolações das informações.

Pelos padrões atuais, a pesquisa in loco das características biofísicas das áreas onde se pretende implantar as unidades de conservação, sejam elas de uso indireto ou direto, jamais poderia ser descartada, pois são de vital importância para a identificação dos verdadeiros atributos do local, sem deixar de lado também as análises de laboratório, que cada indicador natural merece. Além disso, não podem ser esquecidas as questões socioeconômicas da região, que irão fundamentar a escolha das áreas a serem preservadas ou conservadas, respeitando a dinâmica local.

Até meados de 1978 foram recebidos, pelo Departamento de Parques Nacionais e Reservas Equivalentes do IBDF, vinte e seis comentários sobre o relatório, provenientes de vários pesquisadores nacionais e estrangeiros, representando organismos governamentais, institutos de pesquisa, museus, universidades e organizações conservacionistas. De acordo com Wetterberg e Pádua, em geral os comentários foram favoráveis, indicando que o escasso conhecimento científico sobre a Amazônia no período de estudo, levou à adoção de uma metodologia de aproximação, a mais apropriada para o caso ${ }^{500}$.

Pádua et al., nos lembra que o modelo de criação das áreas protegidas no Brasil, foi semelhante ao que ocorrera em outros países da América Latina. A criação dos parques até a década de 1960 se justificava principalmente por razões estéticas, ou seja, pela beleza cênica evidenciada em algumas áreas ${ }^{501}$. Por isso, os autores consideram que o IBDF foi o órgão que iniciou os estudos para a elaboração de um Plano do Sistema de Unidades de Conservação para o país, e que ele se efetivou em face da diversidade de ecossistemas existentes no Brasil e do aproveitamento limitado, em termos culturais, científicos ou recreativos das áreas até então criadas. No entanto, parecem considerar que a escolha das áreas deveria ser baseada em critérios mais técnicos e científicos ${ }^{502}$.

Não obstante, não podemos perder de vista que o relatório do IBDF foi o primeiro estudo a recomendar o estabelecimento de uma rede de unidades de

\footnotetext{
500 WeTterberg. G. B. e PÁDUA, M. T. J. Preservação da Natureza na Amazônia Brasileira: situação em 1978. Brasília: IBDF, PNUD, FAO, 1978, 44p. (PNUD/FAO/IBDF/BRA-76/027, Série Técnica $\left.\mathrm{N}^{\mathrm{o}} 13\right)$, p. 16.

${ }^{501}$ PÁDUA, Maria Tereza Jorge; PORTO, Eduardo Lourenço Rocha; BORGES, Gabriel Cardoso; e BESERRA, Margarene Maria Lima. Plano do Sistema de Unidades de Conservação do Brasil (II Etapa). Brasília: IBDF/FBCN, 1982, p.12.

${ }^{502}$ Id., p. 12
} 
conservação no país, apesar de se apoiar em vários os critérios para a indicação de áreas a serem preservadas.

\subsubsection{O Projeto RADAMBRASIL - 1977}

Como já mencionado no capítulo 3, a região amazônica como um todo foi alvo de um modelo político de ocupação motivada pelos ideais dos governos militares. O objetivo do governo federal era de ocupar os chamados "espaços vazios", consolidando assim uma integração inter-regional, sem muitas preocupações com a questão ambiental ou mesmo social.

Em 1971, o governo brasileiro, com recursos do Plano de Integração Nacional (PIN), lançou o PROJETO RADAMBRASIL, organizado pelo Ministério das Minas e Energia (MME) através do Departamento Nacional de Produção Mineral (DNPM), que seria responsável pelo levantamento dos recursos naturais na Amazônia. Nesta década, o uso do radar de visada lateral (SLAR - side-looking airbon radar) representou um avanço tecnológico, suas imagens podiam ser obtidas durante o dia ou à noite e em condições de nebulosidade ${ }^{503}$.

Inicialmente, foi criado o Projeto RADAM - Radar na Amazônia, que buscou priorizar a coleta de dados sobre recursos minerais, solos, vegetação, uso da terra e cartografia da Amazônia e áreas adjacentes da região Nordeste. Em junho de 1971 foi dado início ao aerolevantamento. Em 1975, os bons resultados do projeto levaram a uma extensão do levantamento por radar para o restante do território nacional, tendo por objetivo um mapeamento integrado dos recursos naturais. Então, o Projeto RADAM passou a denominar-se Projeto RADAMBRASIL ${ }^{504}$.

Apesar dos esforços para a elaboração dos relatórios do Projeto, as características da região amazônica dificultaram a obtenção de informações mais detalhadas. De acordo com o próprio Relatório, o levantamento feito foi de caráter bastante generalizado e, basicamente, apoiou-se na interpretação de imagens de radar, pelas extremas dificuldades de acesso às áreas cobertas por densas florestas e

\footnotetext{
${ }^{503}$ OLIVEIRA, Sérigo Azevedo Marques de. Projeto RADAM-D - Preservação e Disseminação das Imagens originais geradas pelo Projetos RADAM e RADAMBRAIL. 2012. Disponível em <http://www.cprm.gov.br/publique/cgi/cgilua.exe/sys/start.htm?infoid=796\&sid=9> acesso em 01.05 .2014$. 504 OLIVEIRA, 2012.
} 
praticamente desabitadas. Levando as análises a um grau elevado de extrapolação, dos dados obtidos nos pontos amostrados no campo ${ }^{505}$.

Mas, é importante destacar que por mais que tenha havido um grau de extrapolação, cada recurso natural analisado seguiu metodologias já utilizadas em outros trabalhos de caráter científico. Nos estudos dos solos, por exemplo, foram utilizados mosaicos semicontrolados de imagens de radar na escala 1:250.000, obtidos pelo "Sistema Good Year", que foram preliminarmente interpretadas com a utilização estereoscópicos. Essa interpretação possibilitou uma visão dos padrões fisiográficos das áreas, principalmente relevo, drenagem, geologia e cobertura vegetal, permitindo uma noção do conjunto. Além da utilização das imagens foram realizadas a priori consultas ao material bibliográfico disponível sobre a temática, não apenas da área em estudo, mas também de outras regiões que pudessem fornecer informações importantes. E as amostras de solos coletadas em campo, foram submetidas às análises físicas e químicas e de fertilidade. Tais análises foram realizadas nos laboratórios do Serviço Nacional de Levantamento e Conservação dos Solos (SNLCS) - EMBRAPA-MA; Centro de Pesquisas Agropecuárias do Trópico Úmido (CPATU) - EMBRAPA-MA; Superintendência de Desenvolvimento da Região Sul (SULDESUL) - MINTER; e Centro de Estudo de Solos (CES) - ESALQ-USP506. E, mesmo com todas as dificuldades de pesquisa, o relatório RADAM é usado até hoje como base para novas pesquisas sobre os recursos naturais na região amazônica.

Foram publicados vários volumes do Projeto RADAMBRASIL, seguindo uma mesma estrutura, para cada região estudada. Em 1973 foram publicados três volumes: volume 1 - Parte das Folhas SC.23 Rio São Francisco e SC.24 Aracaju; volume 2 Folha SB.23 Teresina e Parte da Folha AS.24 Fortaleza; e o volume 3 - Folha SA.23 São Luís e Parte da Folha AS.24 Fortaleza. Em 1974 publicou-se mais três volumes: volume 4 - Folha SB.22 Araguaia e Parte da Folha SC.22 Tocantins; volume 5 - Folha SA.22 Belém; e volume 6 - Folha NA/NB.22 Macapá. No ano de 1975, outros três volumes foram publicados: volume 7 - Folha SB.21 Tapajós; volume 8 - Folha NA.20 Boa Vista e Parte das Folhas NA.21 Tumucumaque, NB.20 Roraima e NB. 21; e volume 9 - Folha NA.21 Tumucumaque e Parte da Flha NB.21. Em 1976, foram publicados: volume 10 - Folha AS.21 Santarém; volume 11 - Folha NA.19 Pico da Neblina; e

${ }^{505}$ BRASIL. Departamento Nacional da Produção Mineral. Projeto RADAMBRASIL. Folhas SB/SC. 18 Javari/Contamana; geologia, geomorfologia, pedologia, vegetação e uso potencial da terra. Rio de Janeiro, 1977, p. 163.

${ }^{506}$ Id., p.169,173. 
volume 12 - Folha SC.19 Rio Branco. Todas essas regiões estudadas podem ser melhor observadas na Figura 9.

E para a região de estudo do nosso trabalho, foi publicado em 1977 o volume 13, Folhas SB/SC.18 Javari/Contamana, que abrange justamente a região do atual Parque Nacional da Serra do Divisor ${ }^{507}$. O relatório apresentou um estudo dos recursos naturais da região mais ocidental do território brasileiro, compreendendo terras dos Estados do Acre e Amazonas, abrangendo uma área de $75.870 \mathrm{~km}^{2}$, limitando-se ao norte, oeste e sul com o Peru. Assim, como os demais volumes, este relatório foi bastante extensivo, com mais de 400 páginas, apresentando informações sobre a geologia, geomorfologia, pedologia, vegetação e uso potencial da terra, utilizando-se a escala de 1:250.000 (Fig. 9).

O trabalho se estruturou da seguinte forma: Introdução - localização, objetivo e método de trabalho; Estratigrafia - províncias geológicas, descrições das unidades; Paleontologia - histórico das pesquisas paleontológicas; Estruturas - estruturas regionais (Bacia do Acre), estrutura falhadas e estruturas locais; Evolução Histórica formação geológica local; Geologia Econômica - ocorrências minerais, possibilidades metalogenéticas da área, situação Legal dos trabalhos de Lavra e pesquisa mineral; Conclusões, e Recomendações.

A metodologia usada para caracterizar a região baseou-se na utilização dos mosaicos semicontrolados das imagens de radar e faixas de visada lateral na escala de 1:250.000 nas interpretações, aliada às consultas bibliográficas, verificações em campo, em pontos previamente escolhidos para serem amostrados. Para este trabalho foi necessário o apoio de barcos, viaturas e helicópteros. Os trabalhos que culminaram na elaboração do relatório, tiveram a colaboração de várias pessoas, organizações, companhias e autoridades, com destaque para a atuação do Governo do Estado do Acre, PETROBRÁS, CPRM, CNPq, INCRA, Batalhões de Fronteira, além do apoio da Força Aérea Brasileira $(\mathrm{FAB})^{508}$. Esta metodologia permitiu a elaboração de um mapa final apresentado na escala de 1:1.000.000.

\footnotetext{
507 Ibid.

${ }^{508}$ Ibid., p. 11.
} 


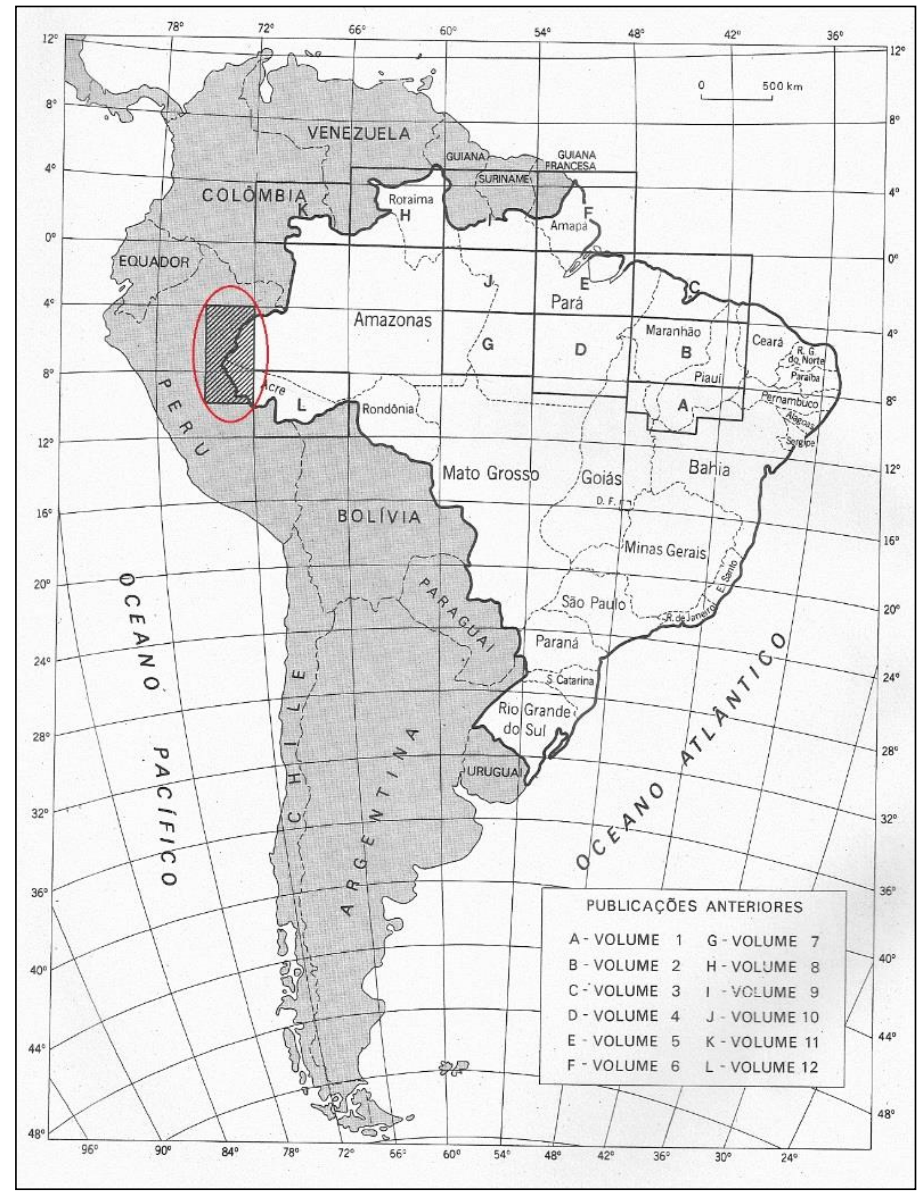

Figura 9 Localização da Área Javari/Contamana caracterizada pelo Projeto RADAMBRASIL (vol.13) Fonte: BRASIL, 1977.

Resumidamente, os estudos apresentados no relatório mostraram que a cidade de Cruzeiro do Sul-AC, foi considerada o centro urbano mais importante de toda a região, levando-se em consideração outras cidades localizadas às margens dos principais rios, como Porto Walter, Taumaturgo, Bom Jesus, Envira e Palmares do Javari. Informa também que o sistema de drenagem constituía-se na via de transporte mais utilizada, sendo representado pelos rios Juruá, ao sul, e Javari, ao norte. Quanto ao relevo, identificou-se uma vasta superfície aplainada que se estendia em direção à Serra do Divisor, na fronteira com o Peru, onde ocorriam as maiores elevações da região, em torno de $700 \mathrm{~m}$ de altitude ${ }^{509}$.

No tocante à geologia, foram caracterizadas duas províncias geológicas, a Bacia do Acre (representada pelos sedimentos neopaleozóicos, cretáceos e da Formação Ramon que constituem as serras do Divisor) e os Depósitos Cenozoicos (sedimentos pelíticos e psamíticos da Formação Solimões e as aluviões holocênicas dos terraços e 
das planícies fluviais), com algumas ocorrências de rochas pré-cambrianas e intrusivas alcalinas. As formas de relevo e suas posições altimétricas, apresentaram três unidades morfoestruturais: Planície Amazônica, Depressão Rio Acre-Javari e Planalto Rebaixado da Amazônia (ocidental). Para cada uma destas unidades, estão presentes as colinas, cristas, interflúvios tabulares, planícies e terraços, tidas como as principais formas de relevo da área ${ }^{510}$.

Nos estudos de pedologia foram apresentados vários tipos de solos, sua distribuição, características morfológicas, físicas e químicas. Identificadas, dentro do caráter generalizado do levantamento, foram apresentados doze tipos de solos $^{511}$, com suas respectivas aptidões agrícolas. Verificou-se que o norte da área analisada, apresenta, na maioria, solos pouco férteis, destacando-se os Podzólicos Vermelho Amarelo Álicos, e em menor proporção, os solos férteis como os Podzólicos Vermelho Amarelo Eutróficos. E devido as característica do relevo desta região (variando de ondulado a forte ondulado) e a alta susceptibilidade à erosão, há limitações para o uso agrícola. Nas planícies de inundação (várzeas), ocorrem solos Gley Pouco Húmico Eutróficos, bastante férteis, de bom potencial para a agricultura. Já na parte sul, o destaque foi para os solos Podzólicos Vermelho Amarelo Eutróficos, de boa fertilidade. A parte central da área, ficou representada com pequenas variações, por solos pouco férteis ${ }^{512}$.

No tocante ao aproveitamento agrícola, verificou-se na área estudada (considerando uma agricultura baseada no sistema rudimentar), que $80 \%$ das terras foram classificadas como inaptas para culturas anuais, observando-se a existência de uma pequena parcela de terras aptas. Devido especialmente ao relevo, a susceptibilidade à erosão, e a dificuldade de mecanização agrícola, quase toda área de terra foi classificada como regulares e restritas para as culturas anuais ${ }^{513}$.

Os estudos fitoecológicos apontaram a presença das Regiões de Campinarana, Floresta Tropical Densa e Floresta Tropical Aberta. Sendo esta última com maior cobertura superficial, $80 \%$ do total mapeado. Também foram identificadas as áreas antrópicas, com cerca de $511 \mathrm{~km}^{2}$. Ficou claro no relatório que a madeira e os

\footnotetext{
${ }^{510}$ Ibid., p. $28,111$.

${ }^{511}$ Latossolo Amarelo Distrófico, Latossolo Vermelho Amarelo Distrófico, Podzólico Vermelho Amarelo Eutrófico, Podzólico Vermelho Amarelo Eutrófico, Podzólico Vermelho Amarelo Álico, Brunizém Avermelhado, Cambissolo Eutrófico e Distrófico, Podzol Hidromórfico, Areias Quartzosas Distróficas, Solos Aluviais Eutróficos e Distróficos, e Solos Litólicos Eutróficos (BRASIL, 1977, p. 177-227)

${ }^{512}$ Id., p. 265.

${ }^{513}$ Ibid., p. 265.
} 
subprodutos florestais foram considerados os dois principais recursos renováveis de significativo valor econômico. Quanto à atividade extrativa, observou-se estar ligada, especialmente, à extração do látex das seringueiras e de óleos essenciais do pau-rosa. Outras espécies de comprovado valor econômico são encontradas na região, como o mogno (Switenia macrophylla) e a palmeira jarina (Phytelephas sp), cujas amêndoas assemelham-se ao marfim, utilizadas para tornearia ${ }^{514}$.

Além dos estudos sobre as características naturais da região, no final do relatório foi apresentado, dentro da temática de uso potencial da terra, um diagnóstico socioeconômico de Cruzeiro do Sul. Que apontou uma população predominantemente rural e de baixa densidade demográfica, sendo o extrativismo da borracha a principal fonte de renda, e agricultura praticada apenas para subsistência. Toda a área estudada foi considerada rica em madeira, além de serem constatadas algumas ocorrências de serrarias e olarias $^{515}$.

Ainda dentro da última temática, do relatório, sobre uso potencial da terra, ficou sugerida a criação de uma reserva florestal, considerando as várias características do local a ser preservado. Ela seria denominada Floresta Nacional do Alto Vale do Juruá, e seria a primeira entidade conservacionista a proteger uma Floresta Aberta com bambu.

A proposta de criação da Floresta Nacional do Alto Vale do Juruá se deu pela justificativa de apresentar atrativos que poderiam também valer para a criação de um Parque Nacional, destacando-se: a localização das terras no extremo oeste brasileiro; o conjunto de blocos elevados, conhecido pela denominação geral de serra do Divisor (contemporâneo do levantamento da Cordilheira Andina); o cañyon do rio Moa, na serra do mesmo nome (um acidente geomorfológico notável); a ocorrência em seu território de três tipos de Floresta Aberta - com palmeira, bambus e cipós - e a Floresta Submontana. E, dentro dessas quatro formações vegetais, a presença da fauna regional, faunas próprias, ficariam preservadas numa área relativamente pequena (Figura 10) ${ }^{516}$.

Assim, o relatório RADAMBRASIL incitou a criação de uma Floresta Nacional, alegando que não existia motivação para a concretização de um Parque Nacional, pois não seria fácil impedir o extrativismo que já se desenvolvia na área. Neste sentido, a categoria Floresta Nacional, além de conciliar a situação existente,

\footnotetext{
514 Ibid., p. 284,362.

515 Ibid., p. 381.

516 Ibid., p. 389.
} 
poderia permitir a racionalização dessas atividades. Quanto à questão da preservação da flora e fauna em condições naturais, o relatório indica que isso podia ser viabilizado através da divisão da área em glebas para manejo e para reserva, como havia sido feito da Reserva Florestal Ducke, do Instituto Nacional de Pesquisas da Amazônia ${ }^{517}$.

O próprio Código Florestal de 1965 , em seu artigo $5^{\circ}$, já previa a criação desse tipo de área protegida, sob responsabilidade do poder público, que teriam fins econômicos, técnicos ou sociais ${ }^{518}$.

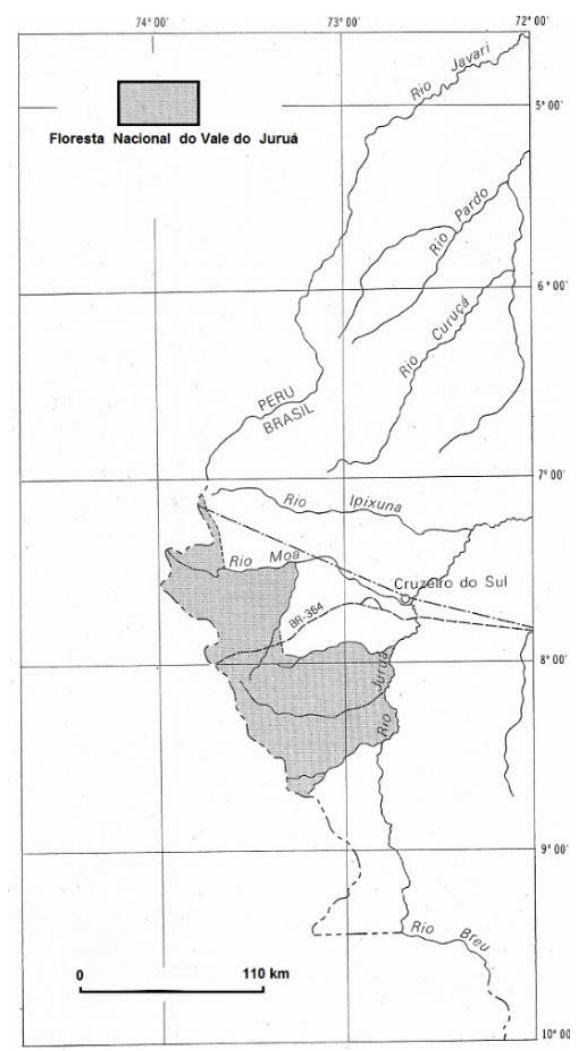

Figura 10 Proposição da criação da Floresta Nacional do Alto Vale do Juruá Fonte: BRASIL, 1977, p. 388.

\subsubsection{O Plano do Sistema de Unidades de Conservação do Brasil-PSUC, 1982 (II Etapa)}

Como vimos no capítulo 2, a iniciativa da criação de um sistema nacional de unidades de conservação no país, iniciou com a publicação, em 1979, do "Plano do Sistema de Unidades de Conservação do Brasil”, pelo Ministério da Agriculta, através da parceria entre o IBDF e a FBCN. Depois de quatro anos da publicação do I PSUC,

\footnotetext{
${ }^{517}$ Ibid., p. 389.

${ }^{518}$ BRASIL. Lei no 4.771, de 15 de setembro de 1965. Institui o novo Código Florestal. Brasília, 1965.
} 
outra versão foi publicada, em 1982, pelas mesmas instituições, visando o aperfeiçoamento do sistema. O novo documento alcançou 173 páginas, sendo dividido em quatro capítulos, que versaram sobre: Unidades de Conservação; Critérios para Seleção de Potenciais Unidades de Conservação; Situação das Unidades de Conservação até 1981; e Unidades Propostas. A maioria dos autores que elaboraram o relatório eram funcionários do IBDF: os Engenheiros Agrônomos Maria Tereza Jorge Pádua, Gabriel Cardoso Borges e Margarene Maria Lima Beserra, e o Geólogo Eduardo Lourenço Rocha ${ }^{519}$.

No primeiro capítulo o documento elencou os objetivos nacionais de conservação da natureza para um sistema de unidades de conservação, as categorias ou tipos de manejo, e ainda os critérios de seleção de cada categoria de manejo. Todos os itens foram copiados sem nenhuma alteração do primeiro PSUC de 1979.

Da mesma forma, o segundo capítulo não trouxe grandes novidades, fazendo apenas uma síntese do relatório "Uma Análise de Prioridades para Conservação da Natureza na Amazônia", publicado em 1976 pelo IBDF. Já no terceiro capítulo, começam a aparecer novos dados, sobre a situação das unidades de conservação já criadas, caracterizadas por região ${ }^{520}$ : Norte, Nordeste, Sudeste, Sul e Centro-Oeste. Verificou-se que até o ano de 1981, o país protegia aproximadamente 10.000.000 de hectares, cerca de 1,2\% do território, contabilizando apenas os Parques Nacionais e Reservas Biológicas ${ }^{521}$.

A maior contribuição do II PSUC, veio no capítulo 4, com as propostas de criação de outras unidades de conservação. Ao todo foram propostas a criação de dezoito unidades de conservação, onde foram apresentadas fichas de análise para todas, contemplando as características biofísicas e socioculturais, de acordo com as informações existentes. Além disso, também foi confeccionado um mapa da área a ser protegida, bem como uma minuta de decreto de criação da unidade.

As unidades de conservação sugeridas abrangeram sete categorias de manejo: Parque Nacional, Reserva Biológica, Parque Natural, Reserva de Recursos, Santuário de Vida Silvestre, Monumento Natural e Estrada Parque, como podemos observar na fig. 11.

\footnotetext{
519 PÁDUA et. al., 1982.

${ }^{520}$ As características descritas abrangiam desde o decreto de criação até as condições biofísicas e socioculturais.

${ }^{521}$ PÁDUA, et. al., 1982, p. 51.
} 


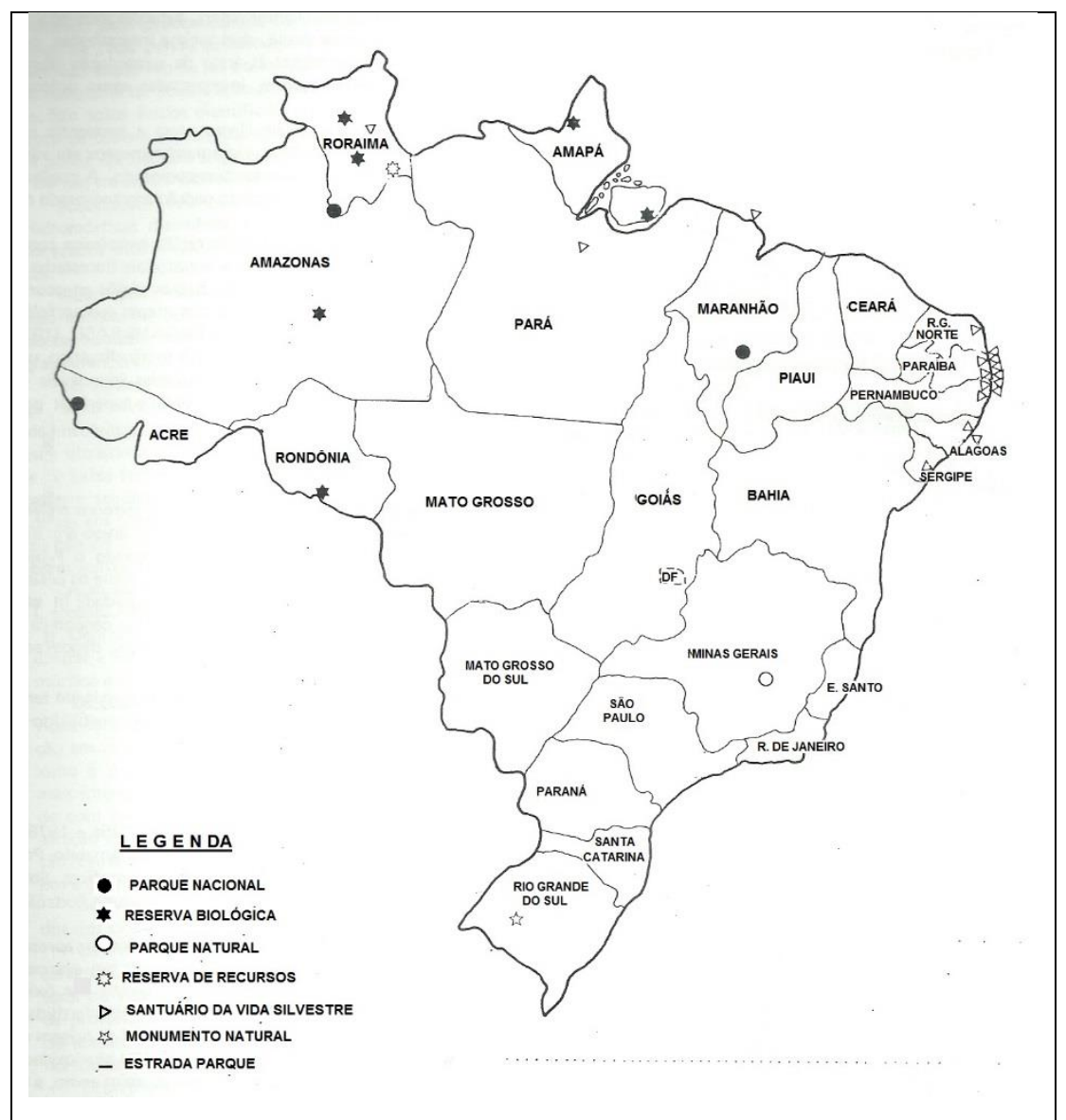

Figura 11 Unidades de Conservação Propostas pelo II PSUC (1982)

Fonte: PÁDUA, et. al., 1982, p. 120

Entre as unidades sugeridas, tivermos a proposta de criação de um Parque Nacional no Estado do Acre, na região da Serra do Divisor. Como vimos, a mesma área, localizada na sétima região fitogeográfica, de acordo com Relatório do IBDF ("Uma Análise de Prioridades em Conservação da Natureza na Amazônia”), de 1976, apontou esta região como de primeira prioridade, para a criação de uma unidade de conservação. Da mesma forma, o RADAMBRASIL, em 1977, sugeriu a criação de uma Floresta Nacional, na mesma localidade. 


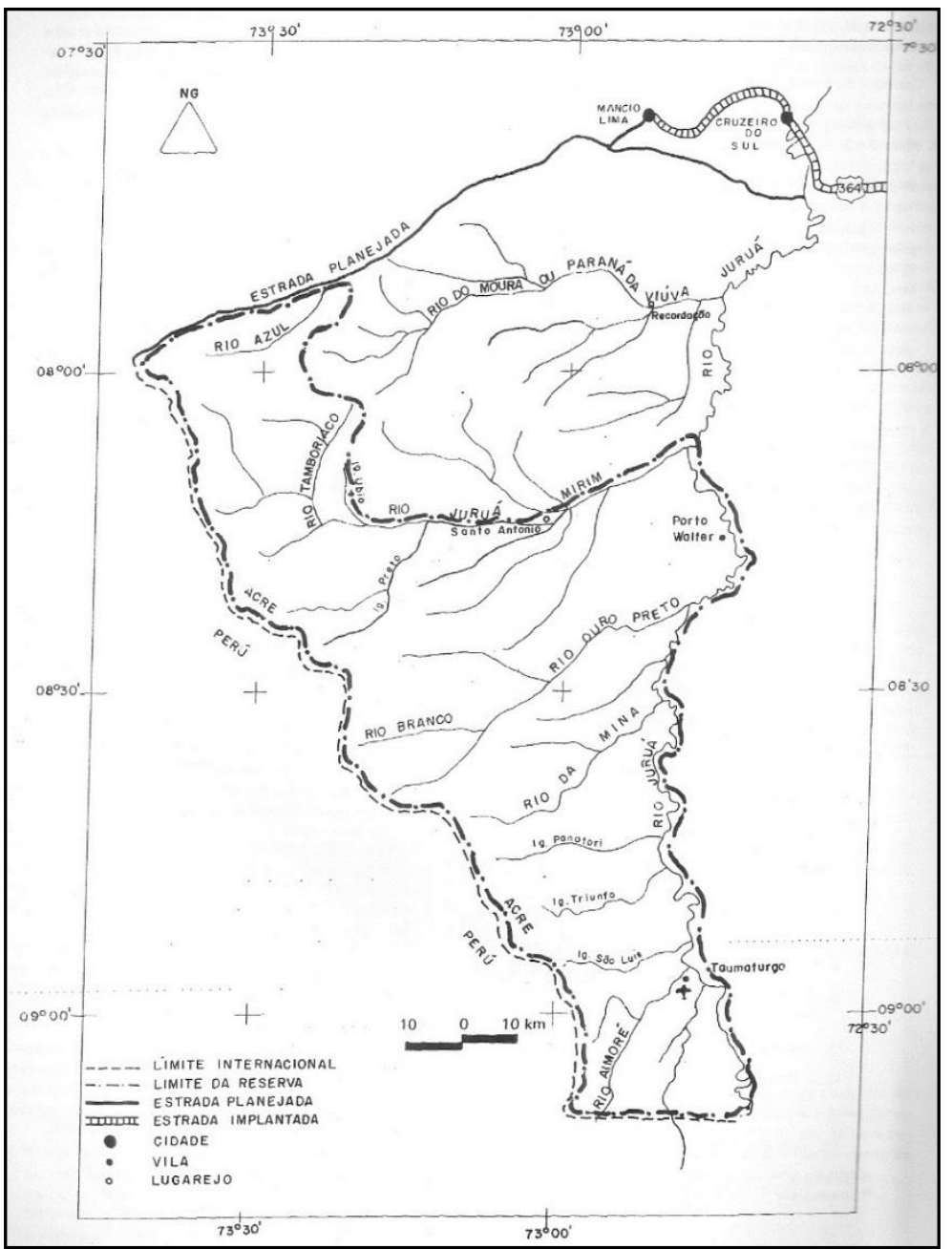

Figura 12 Parque Nacional da Serra do Divisor-AC, proposta pela II Etapa do Plano do Sistema de Unidades de Conservação do Brasil de 1982

Fonte: PÁDUA, et. al., 1982, p. 131.

A Ficha de Análise da área proposta para implantação do Parque Nacional da Serra do Divisor, ficou estruturada da seguinte forma: Identificação; Descrição Resumida do Recurso/Enquadramento da região; Recursos Biofísicos (Fisiografia e Geomorfologia, Geologia, Pedologia, Aptidão Agrícola, Clima, Vegetação, e Fauna); Valores Culturais; Uso Potencial da Terra; Posse da Terra; Conflitos do Uso da Terra; Infra-estrutura existente e prevista; Atividade Projetadas para a Área; Critérios de Avaliação; Declaração de Significância; e a Minuta do Decreto de criação ${ }^{522}$.

De acordo com a ficha de análise, o Parque Nacional da Serra do Divisor, se localizaria na cidade de Cruzeiro do Sul, no Estado do Acre, com superfície aproximada de 605.000 hectares. As características biofísicas e de uso da terra foram semelhantes às

\footnotetext{
522 PÁDUA, et. al., 1982, p. 128-130. Para maiores detalhes ver, em anexo, Quadro 3, Ficha de Análise para o Estabelecimento do Parque Nacional da Serra do Divisor no Acre, proposta pela II Etapa do Plano do Sistema de Unidades de Conservação do Brasil de 1982.
} 
apresentadas na proposta do RADAMBRASIL. O que se teve de novidade foram os critérios de avaliação da área, com treze indicadores. Sete deles foram considerados excelentes na região: Representatividade de Região Fisiográfica Geomorfológica, Diversidade ecológica, Raridade, Qualidade estética, Estado natural, Potencial científico, e por último, Valor para turismo internacional.

Entretanto, não foi possível mensurar os indicadores de Valor Histórico, Cultural e Antropológico, e de Potencial educativo. As informações sobre tais aspectos ainda eram insuficientes. Ao nosso ver, tais aspectos são de grande de relevância, pois trata-se sobretudo de uma população que já vivia no local (seringueiros e índios), que ficaram à margem desta proposta.

Na minuta do Decreto de criação, além da localização geográfica e abrangência do Parque, ficou claro que sua finalidade seria proteger a flora, a fauna e as belezas naturais existente no local, estando sujeito ao regime especial do Código Florestal de 1965.

\subsubsection{A Elaboração dos Planos de Manejo dos Parques brasileiros: 1970-1980}

De acordo com as informações dadas ao pesquisador Gustavo Simas Pereira ${ }^{523}$ pelos principais atores envolvidos diretamente no processo de construção e implantação dos primeiros Planos de Manejo no país ${ }^{524}$, fomos influenciados pelos movimentos internacionais que ganharam maiores proporções a partir da década de 1960.

Segundo Garay B. Wetterberg, então consultor da FAO, em 1976, o IBDF deu início, em Brasília, a um programa para a formação de uma equipe multidisciplinar que atuasse no planejamento dos Parques Nacionais, da qual ele fez parte. E, em setembro do mesmo ano, foi redigido o "Guia de Elaboração de Planos de Manejo e Planos Interpretativos para Unidades do Sistema Brasileiro de Parques Nacionais" ${ }^{525}$. Este guia

\footnotetext{
523 PEREIRA, Gustavo Simas. O Plano de Manejo e o seu Uso como Ferramenta de Gestão de Parques Nacionais no Estado do Rio de Janeiro. Dissertação (Mestrado em Ciências Ambientais e Florestais). 115f. Seropédica-RJ: Universidade Federal Rural do Rio de Janeiro, Instituto de Florestas, 2009.

${ }^{524}$ Dra. Maria Tereza Jorge Pádua (Agente do Instituto Brasileiro de Desenvolvimento Florestal - IBDF); Dra. Ângela Tresinari (Agente do IBDF); Dra. Sônia Wiedmann (Advogada do IBDF); Sra. Lourdes Maria Ferreira (Agente do IBDF); Dr. Garay B. Wetterberg (Consultor da FAO); Dr. Marc Dourojeanni (Diretor do Serviço Peruano de Fauna e Floresta e Vice-presidente da Comissão de Parques Nacionais e Áreas Protegidas da UICN); e Sra. Margarene Maria Lima Beserra (Agente do IBDF).

${ }^{525} \mathrm{O}$ objetivo do documento era servir de referência para a elaboração de Planos de Manejo no Brasil, sendo inspirado no modelo de Planejamento de Parques da FAO e nos manuais interpretativos
} 
foi encaminhado, em setembro de 1976, aos setores responsáveis do IBDF e do Projeto de Pesquisa e Desenvolvimento Florestal do Brasil (PRODEPEF), afim de ser discutido e adaptado com base nas necessidades do país, já que sua elaboração baseou-se nas experiências realizadas em outros países ${ }^{526}$.

Também, em 1977, sob orientação do Dr. Celso Soares de Castro e da Dra. Maria Tereza Jorge Pádua, a equipe do IBDF desenvolveu o esboço de um Plano de Manejo para Parques, utilizando como referência principal o livro do Dr. Kenton Miller, "Planejando Parques Nacionais para o Ecodesenvolvimento - Métodos e Casos da América Latina". Segundo Pádua, outros instrumentos como o Plano de Manejo do Parque Nacional de Volcán Poás da Costa Rica, elaborado sob orientação de Mario Bozan, em 1968, também serviu de base para a elaboração dos primeiros Planos no Brasil $^{527}$.

Nos primeiros planos de manejo elaborados pelo IBDF, adotou-se uma estrutura dividida em quatro capítulos. No primeiro capítulo, entraria o contexto nacional e regional (tratando-se dos objetivos nacionais de gestão, da bacia hidrográfica, da província biogeográfica, do solo, da geologia, das características socioeconômicas, dos transportes, da economia, da demografia, da cultura, da arqueologia, da história, entre outros). No segundo, caberia uma análise da Unidade de Conservação (seriam descritas as mesmas características do primeiro capítulo, mas ficariam limitadas aos recursos dentro da unidade, além da declaração de significância e uma síntese de valores significativos no parque). No terceiro capítulo, entraria a parte de Gestão e Desenvolvimento (seria o capítulo mais significativo do Plano, derivado dos capítulos anteriores e conteria os objetivos gerais de manejo; propostas de alteração dos limites, se necessário; zoneamento, programas de Uso Público e Operações, Áreas de Desenvolvimento; o mapa de zoneamento e o cronograma físico-financeiro). Por fím, o quarto capítulo, trataria da implementação, ou seja, da execução das atividades planejadas no terceiro capítulo ${ }^{528}$.

Em 1978, teve início a elaboração dos primeiros Planos de Manejo, com a meta inicial para três Parques nacionais. Entretanto, naquele momento, o IBDF não dispunha de equipe técnica suficiente para realizar o trabalho e tão pouco podia contratar. A

desenvolvidos pelo Projeto Regional para América Latina em Santiago, Chile (HOROWITZ, 2000 apud PEREIRA, 2009, p. 29).

${ }^{526}$ Id., p. 30.

${ }^{527}$ Ibid., p. 30.

${ }^{528}$ Ibid., p. 31. 
solução foi a celebração de um convênio entre o IBDF e a Fundação Brasileira para a Conservação da Natureza - FBCN, que contratou especialistas para a realização dos trabalhos, sob a coordenação da Dra. Maria Tereza Jorge Pádua ${ }^{529}$. Como vimos, no capítulo 2, essa mesma estratégia foi utilizada quando da elaboração da I e II Etapa do PSUC.

O primeiro parque selecionado foi o de Sete Cidades (Piauí), por apresentar pequena dimensão territorial e ter poucos problemas fundiários. O Plano de Manejo deste parque foi elaborado pelo IBDF e a FBCN através de convênio, e atingiu 61 páginas, estruturado em quatro capítulos. Na introdução foi levantado a situação geográfica e histórica do lugar. Em seguida os capítulos abordaram sobre o Enquadramento Nacional e Regional do parque, a Análise da Unidade de Conservação, Manejo e Desenvolvimento, e Implementação do plano ${ }^{530}$. Mas, contava com a boa vontade do Sr. Raimundo Nonato (Delegado do IBDF no Piauí) para colocar o Plano de Manejo em prática após sua conclusão, em $1979^{531}$.

O segundo foi do Parque Nacional da Amazônia, que teve seu plano elaborado pela equipe do IBDF, com a colaboração da World Wide Fund for Nature - WWF, através de consultoria prestada pela canadense Suzanne W. Barrett, Arquiteta Paisagista (consultora da WWF/UICN) ${ }^{532}$. O Plano foi publicado ainda em 1978, com 154 páginas e com a mesma estrutura já menciona no plano de manejo do parque de Sete Cidades.

O terceiro e último plano, elaborado como piloto, foi o do Parque Nacional de Brasília. Este foi o que levou mais tempo para sua elaboração, em função de uma divergência existente entre os técnicos do IBDF e dois consultores portugueses contratados pela FBCN (Dr. José Manuel Carvalho de Vasconcelos e Dr. David Oliveira Assoreia), mas foi publicado em 1979. Curiosamente, na opinião de Pereira, dos três Planos elaborados, dois tiveram a participação de consultores estrangeiros, o que indicaria, segundo o autor, a falta de profissionais qualificados no país, naquele momento 533 .

Depois da elaboração dos três planos, tornou-se uma possibilidade concreta que essa ferramenta fosse utilizada para todos os Parques Nacionais no Brasil. Diante disso, como vimos no capítulo 2, foi com a publicação do Decreto n. 84.017, de 21 de

\footnotetext{
${ }^{529}$ Ibid., p. 32.

${ }^{530}$ IBDF/FBCN. Plano de Manejo - Parque Nacional de Sete Cidades. Brasília: IBDF/FBCN, 1979.

${ }^{531}$ PEREIRA, 2009, p. 32.

${ }^{532}$ IBDF/WWF. Plano de Manejo - Parque Nacional da Amazônia (Tapajós). Brasília: IBDF/WWF, 1978.

${ }^{533}$ PEREIRA, 2009, p. 32-33.
} 
setembro, que regulamentou os Parques no país, que o Brasil passou a contar com um instrumento que regulamentasse a elaboração e aplicação dessa ferramenta.

$\mathrm{Na}$ entrevista concedida a Gustavo Simas Pereira, em 2009, a Dra. Ângela Tresinari relatou que o Decreto n. 84.017 de 1979 foi criado, dentre outras coisas, para permitir que os demais parques nacionais pudessem ter um plano de manejo, pois até então não havia um instrumento que disciplinasse esta questão ${ }^{534}$. Realmente, no Decreto encontramos a primeira definição jurídica para os Planos de Manejo: “... projeto dinâmico que, utilizando técnicas de planejamento ecológico, determine o zoneamento de um Parque Nacional, caracterizando cada uma das suas zonas e propondo seu desenvolvimento físico, de acordo com suas finalidades ${ }^{, 535}$.

Entretanto, como vimos no Cap. 2, o Decreto que regulamentou os parques não detalhou de forma precisa o conteúdo do plano de manejo, focando com mais ênfase no zoneamento, onde ficou estabelecido sete tipos de zonas (intangível, primitiva, de uso extensivo, e uso intensivo, histórico cultural, de recuperação, de uso especial) com características diferenciadas.

Somente dezessete anos depois da Regulamentação legal dos parques nacionais, em 1996, foi editado o primeiro Roteiro Metodológico para elaboração de Planos de Manejo. O Roteiro foi publicado pelo IBAMA, através da Diretoria de Ecossistemas - DIREC, com o objetivo de atualizar, padronizar e orientar na elaboração dos planos de manejo no país ${ }^{536}$. Para a construção deste Roteiro, o IBAMA teve a colaboração da Cooperação Técnica da República Federal da Alemanha, através da Deutsche Gesellschaft für Technische Zusammenarbeit GmbH ${ }^{537}$.

O Roteiro Metodológico estabeleceu procedimentos gerais para a construção do Plano de Manejo em três fases distinta, a fim de que diferentes profissionais pudessem construí-lo.

\footnotetext{
${ }^{534}$ Id., p. 34.

535 BRASIL. Decreto no 84.017, de 21 de setembro de 1979. Aprova o Regulamento dos Parques Nacionais Brasileiros. Brasília: 1979.

536 IBAMA. (Instituto Brasileiro de Meio Ambiente e dos Recursos Naturais Renováveis). Roteiro Metodológico para Planejamento de Unidade de Conservação de Uso Indireto. Brasília-DF: IBAMA, GTZ, 1996.

537 Cooperação Técnica Alemã é uma empresa pública criada em 1974, apoia o Governo alemão para atingir seus objetivos em matéria de cooperação internacional para o desenvolvimento sustentável. Sua sede está localizada em Bonn e Eschborn. Opera em toda a Alemanha e em mais de 130 países em todo o mundo. Sua agência no Brasil localiza-se em Brasília/DF, Setor Comercial Norte, Quadra 1, Bloco C Ed. Trade Center, Sala 1501 (Agências de implementação da cooperação alemã para o desenvolvimento. Deutsche Gesellschaft für Internationale Zusammenarbeit (GIZ) GmbH. Disponível em: <http://www.brasil.diplo.de/Vertretung/brasilien/pt/Startseite.html > Acesso em: 08 jan. 2015).
} 


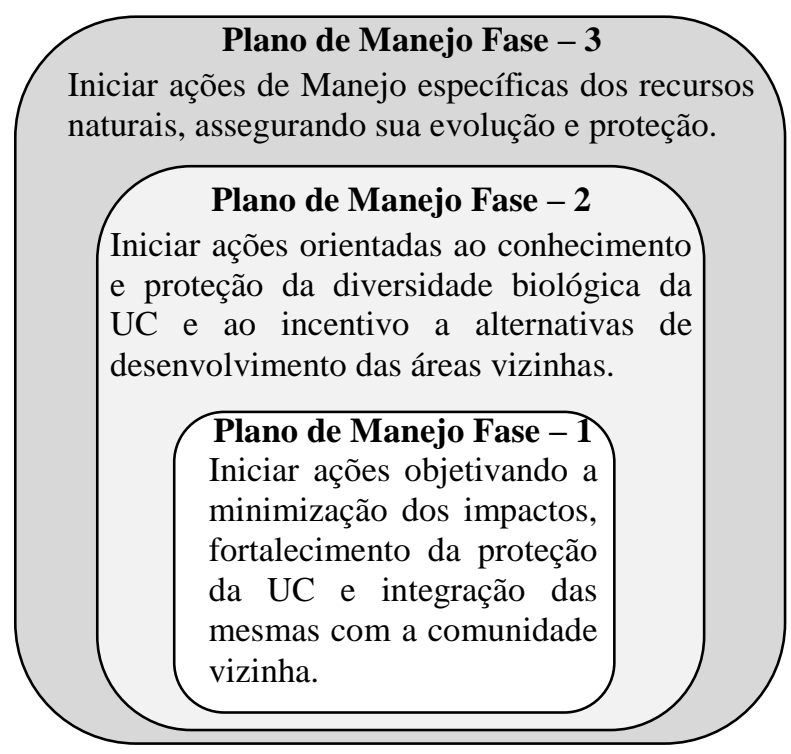

Figura 13 Fases de um Plano de Manejo com base no Roteiro Metodológico de 1996.

Fonte: IBAMA, 1996, p. 5.

As fases evidenciam uma estratégia de planejamento. Correspondem a uma concepção de construção gradual do Plano de Manejo, relacionada ao acréscimo contínuo de informação sobre a unidade em estudo. Como podemos observar na fig. 13, a primeira fase está voltada para as condições internas do parque, através de ações que diminuíssem os possíveis impactos já sofridos. Na segunda fase, a preocupação estaria voltada para o conhecimento das características naturais e de sua proteção juntamente com a preocupação do que se desenvolvia nas áreas vizinhas ao parque. Por último, na terceira fase, tratar-se-ia do manejo dos recursos já estudados na fase anterior, a fim de assegurar a evolução da proteção dos mesmos ${ }^{538}$.

Por fim, consideramos este item importante, pois através desse entendimento sobre a elaboração de um plano de manejo, facilitará nosso entendimento sobre o processo de elaboração do Plano de Manejo do Parque Nacional da Serra do Divisor.

\footnotetext{
538 O Roteiro Metodológico para Planejamento de Unidade de Conservação de Uso Indireto de 1996 foi utilizado até 2002, quando da publicação, também pelo IBAMA, de um novo documento intitulado "Roteiro Metodológico de Planejamento: Parque Nacional, Reserva Biológica, Estação Ecológica" (IBAMA. Instituto Brasileiro de Meio Ambiente e dos Recursos Naturais Renováveis. Roteiro Metodológico de Planejamento: Parque Nacional, Reserva Biológica, Estação Ecológica. Brasília: IBAMA, 2002).
} 


\subsection{A criação do Parque Nacional da Serra do Divisor - PNSD: 1989}

As fontes até aqui analisadas nos permitem apontar que a criação do Parque Nacional da Serra do Divisor (PNSD), em 1989, não foi por acaso. Como vimos, foram realizados nos anos 1970 e 1980, uma série de estudos, que indicavam esta área como propícia aos objetivos de conservação, tendo em vista, sua vasta diversidade biológica.

No entanto, a decisão de criação do Parque ficou por conta do governo federal, sem consultas públicas ou qualquer outra participação da comunidade local. Foi assim, uma determinação tomada "de cima para baixo".

O PNSD foi criado de acordo com as exigências e objetivos estabelecidos pelo Regulamento dos Parques Nacionais do Brasil publicado em 1979 que, como vimos, no cap. 2, tinha como base os requisitos estabelecidos na X Assembleia Geral da IUCN, realizado em Nova Delhi, em 1969.

De acordo com o artigo $1^{\circ}$ do Decreto de criação do PNSD, ele abrangeu terras dos municípios de Mâncio Lima e Cruzeiro do Sul, com objetivo de "proteger e preservar amostra dos ecossistemas ali existentes, assegurando a preservação de seus recursos naturais, proporcionando oportunidades controladas para uso pelo público, educação e pesquisa cientifica" ${ }^{539}$.

O decreto descreveu os limites do parque de acordo com as cartas na escala de 1:250.000, números SB.189-2-D/C, SC-18-X-D e SC-18-X-B/A, editadas pelo Departamento Nacional de Produção Mineral, em 1977 (RADAMBRASIL). Entretanto, não foi informado o tamanho da área a ser preservada.

No artigo $3^{\circ}$ do Decreto, ficou autorizada a implantação futura de um trecho da BR-364 que cortaria os limites deste parque, enfatizando que deveriam ser observadas todas as medidas de proteção ambiental e compatibilização do traçado com as características naturais.

Também ficou estabelecido no Decreto, o prazo de cinco anos para a elaboração do Plano de Manejo. As terras e benfeitorias localizadas dentro dos limites descritos, ficariam declaradas como de utilidade pública, para fins de desapropriação. Por fim, o parque ficou sob a responsabilidade do Instituto Brasileiro do Meio Ambiente e dos Recursos Naturais Renováveis - IBAMA ${ }^{540}$.

\footnotetext{
${ }^{539}$ BRASIL. Decreto n. 97.839, de 16 de julho de 1989. Cria o Parque Nacional da Serra do Divisor. Brasília: 1989.

${ }^{540}$ Os detalhes do Decreto podem ser observados no Quadro 4, em anexo.
} 
Um fato marcante nos chama atenção no Decreto. No artigo $3^{\circ}$ ficou autorizada a implantação de um trecho da BR-364, cortando os limites do parque. Esta estrada poderia ameaçar todo a área do parque, uma vez que se faz necessário proteger uma faixa fora dos seus limites, para evitar os efeitos de borda. Os efeitos de bordas podem ser exemplificados como consequência da fragmentação de habitats florestais. Segundo Viana, um fragmento florestal é qualquer área de vegetação natural contínua, interrompida por barreiras antrópicas, como estradas, cidades, culturas agrícolas, pastagens e até mesmo naturais, como montanhas, lagos, capazes de diminuir o fluxo de animais, pólen e/ou sementes ${ }^{541}$. Estudos como os de Laurance e Bierregaard, 1997; e Bierregaard et. al., 2001, têm apontado que nas florestas tropicais do Brasil, estão sendo registradas que o efeito de borda tem sido um dos principais fatores que vêm ameaçando as espécies, em paisagens fragmentadas ${ }^{542}$.

Esta situação nos revela uma verdadeira contradição quanto aos objetivos de criação de um parque! Como assegurar a preservação dos recursos naturais de um ecossistema onde irá ser implantada uma rodovia?

Devemos lembrar que já no artigo $4^{\circ}$ do Decreto n. 84.017 , de 1979 , que aprovou o Regulamento dos Parques no país, era vedada a execução de obras que visassem a construção de teleféricos, ferrovias, rodovias, barragens, aquedutos, oleodutos, linhas de transmissão, ou outras ${ }^{543}$ que não fossem de interesse para o ambiente a ser protegido. Felizmente, devido à dificuldade de acesso e alto custo para a construção de uma estrada na região, até o momento a rodovia não foi concluída naquele trecho.

Quanto ao Plano de Manejo, vimos que no Decreto foi estabelecido o prazo de cinco anos para a sua elaboração. No entanto, este documento só foi publicado após nove anos, em 1998, por iniciativa de uma organização não governamental, a SOS AMAZÔNIA (criada no estado do Acre em 1985), como veremos no próximo item.

\footnotetext{
${ }^{541}$ VIANA, 1999 apud BARROS, Christiane A. de S. e BUENO, Cecília. Breve Caracterização do Efeito de Borda no Parque Natural Municipal de Marapendi - Rio de Janeiro. In: VIII Congresso de Ecologia do Brasil, 2007, Caxambu-MG. Anais... Caxambu-MG: Universidade Veiga de Almeida, Curso de Ciências Biológicas, p. 1-2, 23 a 28 de set., 2007.

${ }^{542}$ ARAÚJO, 2007, p. 20.

543 BRASIL. Decreto n. 84.017, de 21 de setembro de 1979. Aprova o Regulamento dos Parques Nacionais Brasileiros. Brasília: 1979.
} 


\subsection{Elaboração e Publicação do Plano de Manejo do PNSD-AC: 1995 a 1998}

\subsubsection{Atores envolvidos na coordenação e elaboração do Plano de Manejo do PNSD}

Os trabalhos para o plano de manejo do PNSD iniciaram-se em 1995, sob a coordenação e execução de uma organização não governamental, a SOS AMAZÔNIA, sendo concluído em 1998.

A SOS Amazônia é uma associação civil com personalidade jurídica de direito privado, com fins não econômicos, de âmbito nacional, apartidária, com sede e foro na cidade de Rio Branco-AC, situada na Rua Pará, no 61, bairro Cadeia Velha ${ }^{544}$. A associação foi criada no dia 30 de setembro de 1988, resultante do movimento articulado de um grupo de estudantes, profissionais liberais e representantes do movimento comunitário e social local ${ }^{545}$, que defendiam a ideia de que, melhorando as condições de vida dos homens na Amazônia, a preservação da floresta seria garantida. $\mathrm{O}$ processo de criação da SOS Amazônia acompanhou o período de maior combate ao desmatamento no Estado, ocorrido na década de 1980.

De acordo com o histórico disponível em seu próprio site, a entidade tem como missão principal "promover a conservação da biodiversidade, o desenvolvimento sustentável e o crescimento da consciência ambiental na Amazônia" ${ }^{546}$. E, de acordo com o Estatuto Social da Associação, capítulo II, os objetivos estatutários basearam-se em promover e apoiar ações que visassem: a preservação, conservação, defesa e recuperação ambiental, com prioridade para os ambientes da Amazônia, em particular, do Estado do Acre; assessorar técnica e juridicamente causas envolvendo questões ambientais, inclusive propor ações judiciais; promover ações de educação ambiental, formal e não formal, envolvendo todos os segmentos da população; criar comitês ou comissões de acompanhamento de órgãos fiscalizadores da aplicação da legislação ambiental; elaborar e executar programas e projetos na área ambiental; celebrar

\footnotetext{
${ }^{544}$ Desde setembro de 2001 está qualificada como Organização da Sociedade Civil de Interesse Público OSCIP. A SOS possui escritórios nos municípios de Rio Branco e Cruzeiro do Sul.

${ }^{545}$ Dentre os representantes dos movimentos sociais, a instituição teve o líder seringueiro Chico Mendes como um de seus fundadores.

546 SOS AMAZÔNIA. Nossa História. Disponível em: http://sosamazonia.org.br/oscip/quemsomos/nossa-historia/>. Acesso em: 12 nov. 2013.
} 
convênios, acordos e contratos com organizações e entidade públicas e privadas, nacionais e internacionais, com vistas a atingir seus objetivos; dentre outros ${ }^{547}$.

A elaboração do Plano de Manejo do PNSD foi fruto do acordo de Cooperação Técnica, celebrado entre o IBAMA, a SOS Amazônia e The Nature Conservancy (TNC), com apoio financeiro da United States Agency for International Devolopment (USAID).

Fundada em 1951, a TNC é uma das organizações de conservação mais antigas do planeta, composta por um grupo de cientista norte-americanos interessados em estudar a natureza e protege-la. Seu principal objetivo é proteger a natureza e preservar a vida, e sua missão é conservar as terras e águas das quais a vida depende ${ }^{548}$.

Em 1980 a organização lançou um programa de conservação internacional para identificar áreas naturais e organizações de conservação na América Latina que precisavam de assistência técnica e financeira. Atualmente está presente em mais de 35 países, entre eles o Brasil, onde trabalha desde $1988^{549}$, atuando em todos os biomas. De acordo com as informações disponível em seu próprio site (http://www.tnc.org.br), no Brasil. De todo trabalho realizado, $76 \%$ concentra-se em programas de conservação, $14 \%$ englobam as funções administrativas e $10 \%$ na arrecadação de fundos e programas de membros.

O Plano de Manejo do PNSD, ficou sob a coordenação geral do geógrafo Miguel Scarcello (Secretário Geral da SOS Amazônia), enquanto que a coordenação científica ficou sob a responsabilidade da Dra. Verônica T. da Rocha Passos (Geógrafa), com apoio técnico institucional de uma equipe da The Nature Conservancy, composta por Luciana Honigman (Diretora de Ciências - Programa do Brasil), Ângela Tresinari (Diretora de Projetos - Programa do Brasil), Paquita Bath (Diretora da Rede de Treinamentos para Conservação), Steve Cox (diretor do Programa do Brasil) e, Nanete Rutsch (Coordenadora de Operações Regionais). A Equipe Técnica da SOS AMAZÔNIA foi composta por Maria Letícia Rosa dos Santos (Agrônoma), Amauri Siviero (Mestre em Agronomia), Rosemeire de Castro Correia (Socióloga), Rosemary Silva Vieira (Mestre em Ecologia), Claúdia Calegaro Marques (Mestre em Ecologia), e Mauro César Rocha da Silva (Estagiário da Universidade Federal do Acre - UFAC),

\footnotetext{
${ }^{547}$ ESTATUTO SOCIAL ASSOCIAÇÃO S.O.S AMAZÔNIA. Rio Branco-AC: Cartório de Registros de Títulos e Documentos de Registro Civil da Pessoas Jurídicas, 18 de janeiro de 1996.

${ }^{548}$ Quem é a TNC? Disponível em: <http://www.tnc.org.br/quem-e-a-tnc/index.htm>. Acesso em: 08 jan. 2015.

${ }^{549}$ Em 1994, com a expansão do seu trabalho na América Latina, um escritório foi aberto em Brasília. Atualmente a já existem escritórios também no Rio de Janeiro, Belém, Cuiabá, Curitiba e São Paulo.
} 
além da Equipe Administrativa da SOS Amazônia, Kelly Gouveia (Contadora) e Leila Hoffmann (Secretária) ${ }^{550}$.

Os levantamentos de campo relativos à flora e fauna foram realizados com a cooperação de várias instituições: Universidade Federal do Acre - UFAC; Fundação Tecnológica do Acre - FUNTAC; Universidade Federal Rural do Rio de Janeiro UFRRJ; Universidade Federal do Rio de Janeiro - UFRJ; Museu Paraense Emílio Goeldi; Universidade Estadual de Londrina, e New York Botanical Garden - NYBG ${ }^{551}$.

Já o levantamento socioeconômic,o foi realizado por técnicos da SOS Amazônia, com a colaboração de algumas instituições que cederam seus funcionários, como o Sindicato dos Trabalhadores de Cruzeiro do Sul, o Instituto Nacional de Reforma Agrária - INCRA de Cruzeiro do Sul, o Centro Nacional de Desenvolvimento Sustentado das Populações Tradicionais (CNPT), e o Conselho Nacional de Seringueiros $^{552}$. O IBAMA contribuiu com a parte de Geoprocessamento e com a digitalização e confecção de mapas. Consta no Plano que todas as fases do trabalho foram acompanhadas e discutidas pelo IBAMA e TNC.

\title{
4.4.2 Elaboração e Publicação do Plano de Manejo
}

O Plano de Manejo do PNSD seguiu as orientações propostas pelo Roteiro Metodológico para a Elaboração de Planos de Manejo de Unidades de Conservação de Uso Indireto, publicado pelo IBAMA em 1996. De acordo com Miguel Scarcello, na época, Coordenador Geral da elaboração do Plano de Manejo:

\begin{abstract}
A metodologia foi estabelecida pelo IBAMA. Já era um roteiro metodológico que estava sendo aplicado na época, que condicionava todos os procedimentos. Nós tínhamos que cumprir todo um roteiro, passo a passo, não tinha como alterar. Caso houvesse uma intenção de mudar alguma coisa, tinha que ser autorizado pelo IBAMA. Caso não fizéssemos dessa maneira esse documento poderia ser suspenso ou não ser incluído no documento. Então a SOS ficou condicionada a elaborar o documento da maneira que eles queriam $^{553}$.
\end{abstract}

Inicialmente era necessário enquadrar o Plano de acordo com as Fases 1, 2 ou 3, caracterizadas pelo Roteiro Metodológico (Quadro 5, em anexo). Entretanto, se

\footnotetext{
550 SOS AMAZÔNIA, 1998.

${ }^{551} \mathrm{Id}$.

552 Ibid., p. 3 (Encarte 5).

553 Entrevista concedida à autora pelo geógrafo Miguel Scarcello, gestor da SOS Amazônia, em Rio Branco, em 15.01.2014.
} 
fossem levados em consideração os critérios usados em conjunto - planejamentos

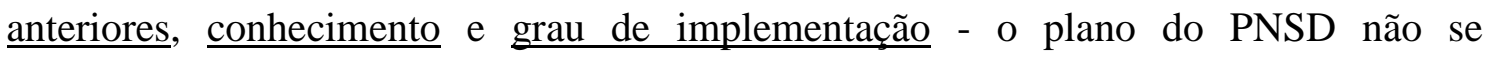
enquadraria em nenhuma das fases descritas pelo Roteiro Metodológico.

$\mathrm{Na}$ Fase 1, o pressuposto é que ainda não existisse nenhum instrumento de planejamento anterior, e a base de conhecimento sobre a Unidade de Conservação seria limitada. Na Fase 2, a ideia era que já existisse um instrumento prévio de planejamento, e uma base de dados sobre a UC. E por último, para se encaixar na Fase 3, o pressuposto é de que já existisse um instrumento de planejamento e a base de dados fosse suficiente para o manejo completo da Unidade ${ }^{554}$.

Assim, caso fosse levado em conta a existência de um instrumento de planejamento e seu grau de implementação, ou as ações específicas de manejo, o enquadramento na Fase 2 ou Fase 3 não se aplicaria, já que não existia naquele momento nenhum instrumento de planejamento prévio ou alguma ação de manejo. Mas, se tais critérios fossem usados o Plano de Manejo se enquadraria na Fase 1.

Porém, se fosse considerado o conhecimento requerido para a elaboração de um instrumento de planejamento, o plano enquadrar-se-ia na Fase 3, pois muitas informações requeridas já estavam disponíveis. Então, a equipe de estudiosos chegou à conclusão de que o Plano de Manejo do PNSD se enquadraria em um nível intermediário, neste caso, na Fase $2^{555}$. Com base no Roteiro Metodológico do IBAMA, ao término das três fases de estudo, o documento do Plano de Manejo, deveria apresentar uma estrutura composta de oito capítulos ou encartes (Encarte 1Informações gerais, da UC, Encarte 2 - Contexto Federal, Encarte 3 - Contexto Estadual, Encarte 4 - Contexto Regional, Encarte 5 - Unidade de Conservação e Zona de Transição, Encarte 6 - Planejamento da UC, Encarte 7 - Projetos Específicos, e Encarte 8 - Monitoria e Avaliação) ${ }^{556}$.

No caso do Plano de Manejo do PNSD, a estrutura do documento foi composta de seis Encartes: 1 - Informações Gerais do Parque Nacional da Serra do Divisor, 2 Contexto Federal, 3 - Contexto Estadual, 4 - Contexto Regional, 5 - O PNSD e sua Zona de Transição e, 6 - Planejamento do PNSD. Os seis capítulos ou encartes contidos no plano se justificam pelo seu enquadramento prévio na FASE 2 do Roteiro Metodológico.

\footnotetext{
554 IBAMA, 1996.

555 SOS AMAZÔNIA, 1998, p. 3, (Encarte 5).

${ }^{556}$ Detalhes na Quadro 6, em anexo.
} 
Para os levantamentos em campo, a área do Parque foi dividida em dois setores: Norte e Sul, por razões logísticas e espaciais, pois se tratavam de duas bacias hidrográficas: a do rio Môa (Norte) e a do rio Juruá (Sul) (ver Mapa 8, pag. 144).

Durante o levantamento de campo utilizou-se a metodologia Avaliação Ecológica Rápida ${ }^{557}$ - ERA, elaborada pela The Nature Conservancy em 1992, com formulários adaptados para a região do PNSD. Em seu depoimento o professor Elder Ferreira Morato trata desta metodologia, presente principalmente na literatura da América Latina:

\begin{abstract}
... quando ela surgiu, apresentou uma possibilidade muito grande de se trabalhar de uma forma rápida, de tal forma que se gerassem os inventários, listas de espécies para que se pudesse estabelecer zonas dentro dessas unidades que estavam sendo criadas. Então, a SOS comprou essa ideia. Inclusive foram feitos vários treinamentos em que os pesquisadores eram capacitados para realizar esses processos (...) é usado até hoje para dar subsídios em planos de manejo, nos zoneamentos e levantamentos de áreas de uso da terra (...) é a única metodologia pertinente. Inclusive, o paradoxo que se tem em relação à conservação, de que para se conservar a gente não pode esperar muito tempo, e como a criação das Unidades flutuam muito de acordo com a política que o país está vivendo naquele momento, então o tempo que se tem para catalogar todas as informações é um tempo muito exíguo. Então, nesse sentido, a avaliação ecológica rápida ajuda muito, é a melhor e a mais eficaz ${ }^{558}$.
\end{abstract}

Também, na opinião do ecólogo Marcos Silveira, que participou do processo de coleta e elaboração do Plano de Manejo do PNSD, a Avaliação Ecológica Rápida foi muito eficiente,

... uma metodologia rápida e viável. Levanta várias informações em um curto espaço de tempo, mais barata do que outras, eu julgo que essa metodologia até hoje é uma das melhores, lembrando que a do Parque Nacional foi uma das pioneiras e uma das melhores também. Eu participei em uma reunião na Flórida onde foi citada a experiência do Acre nesse processo ${ }^{559}$.

A metodologia foi também avaliada de forma positiva pelo ecólogo Armando Muniz Calouro, que colaborou nas pesquisas sobre Mastofauna. Na sua visão:

É uma metodologia usual e conhecida. A Avaliação Ecológica Rápida é uma maneira de você pegar muitas informações com um menor custo, pois você trabalha com uma quantidade mínima de amostras. É uma metodologia

\footnotetext{
${ }^{557}$ SOBREVILLA, C.; BATH, P. Evaluación ecológica rápida: um manual para usuários de América Latina y el Caribe. Washington: The Nature Conservancy, 1992.

${ }^{558}$ Entrevista concedida à autora pelo Ecólogo Elder Ferreira Morato, professor da Universidade Federal do Acre, em Rio Branco, em 02.04.2014.

${ }^{559}$ Entrevista concedida à autora pelo Ecólogo Marcos Silveira, professor da Universidade Federal do Acre, em Rio Branco, em 11.07.2014.
} 
publicada, usual. Ela é bem válida. Inclusive é utilizada até hoje nos planos de manejo, para pegar o máximo de informação possível ${ }^{560}$.

A AER foi usada para o levantamento da fauna e flora da região do PNSD. Para tanto, de acordo com a divisão do parque em Setor Norte e Setor Sul, foram também selecionados sítios de observação, de acordo com seus limites naturais, representatividade, grau de pressão antrópica e acessibilidade. Além dos critérios citados, também foram considerados os estudos preliminares já existentes sobre a vegetação da área de estudo e de ambientes semelhantes; o mapeamento através de imagens de satélite, que geraram diferentes tipos de polígonos produzidos pela interpretação das imagens e que representavam a princípio dez classes de tipologias florestais; e, a viagem de reconhecimento. Lembrando que o levantamento faunístico foi realizado nos mesmos sítios previamente caracterizados pela equipe de vegetação ${ }^{561}$.

Como mencionamos o Plano do PNSD, foi constituído de seis encartes. O primeiro encarte, tratou das informações gerais do parque. Neste foi apresentado a Ficha Técnica, o Acesso, Histórico e Antecedentes Legais, Origem do Nome, e Situação Fundiária.

Vimos que no Decreto de Criação do PNSD (1989) a área total não foi calculada, entretanto, quando da publicação do II PSCU, em 1982, já havia um cálculo de 605.000 hectares. Agora no Plano de Manejo, a superfície total do parque foi calculada com técnicas de cartografia computadorizada pelo Centro de Sensoriamento Remoto do IBAMA, em Brasília, ficando registrada em 843.012,28 hectares, e perímetro de 809.040 metros. Quanto aos municípios que fazem parte da área do parque, foram citados, Cruzeiro do Sul, Mâncio Lima, Rodrigues Alves, Marechal Taumaturgo e Porto Walter ${ }^{562}$.

De acordo com os levantamentos do INCRA, 408.000 hectares já são de propriedade da União. Oito glebas, já foram arrecadadas pelo INCRA, e estão localizadas principalmente no extremo ocidental do parque, que inclui toda a área de montanhas ao longo da fronteira com o Peru. O restante das terras, estavam ocupadas por trinta e duas proprietários particulares. As quinze propriedades situadas na bacia dos rios Môa/Azul (Setor Norte do Parque) passariam por processo discriminatório e estudo da cadeia dominal. Outras dezessete propriedades, situadas na região do Rio Juruá

560 Entrevista concedida à autora, pelo Ecólogo Armando Muniz Calouro, professor da Universidade Federal do Acre, em Rio Branco, em 25.03.2014.

${ }^{561}$ SOS AMAZÔNIA, 1998, p. 10 (Encarte 5).

${ }^{562}$ Id., p. 4 (Encarte 1). 
(Setor Sul do Parque), estavam registradas pelo órgão de terras estadual, sem estudo fundiário ${ }^{563}$.

O que nos chamou atenção no Encarte 1, foi a questão fundiária de toda a área do parque. Quando da criação legal do parque, ficou decretado que as terras e benfeitorias localizadas dentro da área, foram declaradas de utilidade pública, para fins de desapropriação. Entretanto, como se passaram mais de 25 anos, e a lei determina o prazo de cinco anos, com carência de um ano, para que a desapropriação ocorra, houve caducidade do Decreto. Neste sentido, torna-se necessário uma reedição do artigo que faz menção ao processo de desapropriação, para que se possa validar novamente a situação.

Mas, o levantamento sócio-econômico realizado para o Plano de Manejo, indicou a existência de 72 proprietários particulares, e muitas das denominações das localidades, bem como os nomes dos proprietários, não coincidiram com as informações levantadas pelo INCRA. Embora a listagem do INCRA conste a existência de muitos seringais, a maioria foi denominadas fazendas pelos próprios entrevistados. Algumas com cerca 1.000.000 hectares de extensão ${ }^{564}$.

No final dos levantamentos sócio-econômicos, registrou-se a presença de 522 famílias, 165 no Setor Norte e 357 no Setor Sul. As famílias dependem diretamente dos recursos naturais da região, exercendo atividades econômicas que conforme o Decreto de criação do parque, são incompatíveis. As atividades incluem a agricultura de subsistência, extração de látex, criação de animais, pesca, pecuária de pequeno porte, extrativismo de produtos florestas, extração de madeiras, caça de subsistência e comercial $^{565}$.

No Encarte 2, foi tratado sobre o Contexto Federal, o Sistema Nacional de Unidades de Conservação (SNUC), e das Diferentes Formas de Classificação de Unidades Ambientais no país. Neste, o plano aborda um levantamento histórico do sistema nacional de unidades de conservação no Brasil no âmbito federal, descrevendo de forma sucinta as categorias de uso indireto, seus respectivos decretos de criação e mapas temáticos, acompanhados de uma resumida explicação ${ }^{566}$. Este Encarte não traz novidades neste momento, pois em nosso trabalho, já realizamos um levantamento de todas as unidades de conservação no âmbito federal, como consta em todo o cap.2.

\footnotetext{
${ }^{563}$ Ibid., p. 13 (Encarte 1).

${ }^{564}$ Ibid., p. 15 (Encarte 1).

565 Ibid., p. 15 (Encarte 1).

${ }^{566}$ Ibid., p. 1-19 (Encarte 2).
} 
Já no Encarte 3, buscou-se mostrar o Contexto Estadual, através das características apresentadas nos subitens: Estado do Acre: Divisão Política e Administrativa e Demografia; Unidades de Conservação; Uso e Ocupação do Solo; e por último, apresentou os Órgãos Governamentais e Não Governamentais. Como nosso objetivo, é explorar as características do PNSD, achamos conveniente não aprofundarmos nas características do Estado como um todo, mas fazer uma breve caracterização do contexto regional da área que situa a Unidade de Conservação em estudo (Encarte 4).

O Encarte 4, tratou do Contexto Regional, através da Descrição da Área de Influência; Uso e Ocupação do Solo e Principais Atividades Econômicas; Caracterização da População; Características Culturais; Infra-Estrutura de Apoio ao PNSD; Ações Ambientais Exercidas por outras entidades; e Apoio Institucional.

A microrregião de Cruzeiro do sul (Mapa 2, pag. 110), agrupa os municípios de Cruzeiro do Sul, Mâncio Lima, Porto Walter, Rodrigues Alves e Marechal Thaumaturgo, que compõe a Área de Influência do PNSD. Os dados de 1996, registram que esta microrregião correspondia a $19,3 \%$ de todo o território do Estado, com uma população de 87.556 habitantes (cerca de $18 \%$ da população do Estado), e uma densidade demográfica de 2,94 hab./ $\mathrm{km}^{2}$. Esta microrregião possui uma linha de fronteira internacional com o Peru, mas, de acordo com Plano de Manejo, não constitui uma Área de Influência do parque pois é uma área que está fora do país ${ }^{567}$. Entretanto, do ponto de vista ecológico, esta região de fronteira não poderia ter sido deixada de fora, pois toda unidade de conservação necessita de uma faixa de transição em todo seu perímetro, para sua proteção contra os efeitos de borda.

De acordo com os dados do INCRA, de 1996, a microrregião de Cruzeiro do Sul possuía cerca de 1.495 imóveis rurais cadastrados, totalizando uma área de 305.265 ha. Deste total, $85 \%$ (1.268) dos imóveis estavam classificados como minifúndios, ocupando 29,2\% da área. Por outro lado, 1,6\% dos imóveis (24) foram classificados como de grande propriedade improdutiva, ocupando $61 \%$ da área. Isso nos remete a uma extrema concentração fundiária ${ }^{568}$.

Existia naquele momento 21 áreas públicas instaladas pelo governo federal na microrregião, cobrindo mais de $18.000 \mathrm{~km}^{2}$, aproximadamente $60 \%$ da área. Além do PNSD, faziam parte da área, uma reserva extrativista, onze assentamentos agrícolas e

${ }^{567}$ Ibid., p. 4 (Encarte 4).
${ }^{568}$ Ibid., p. 8 (Encarte 4). 
sete áreas indígenas. $\mathrm{O}$ restante das terras da microrregião estava ocupada por cinco núcleos urbanos, antigos seringais, colônias agrícolas e fazendas para criação de $\operatorname{gado}^{569}$.

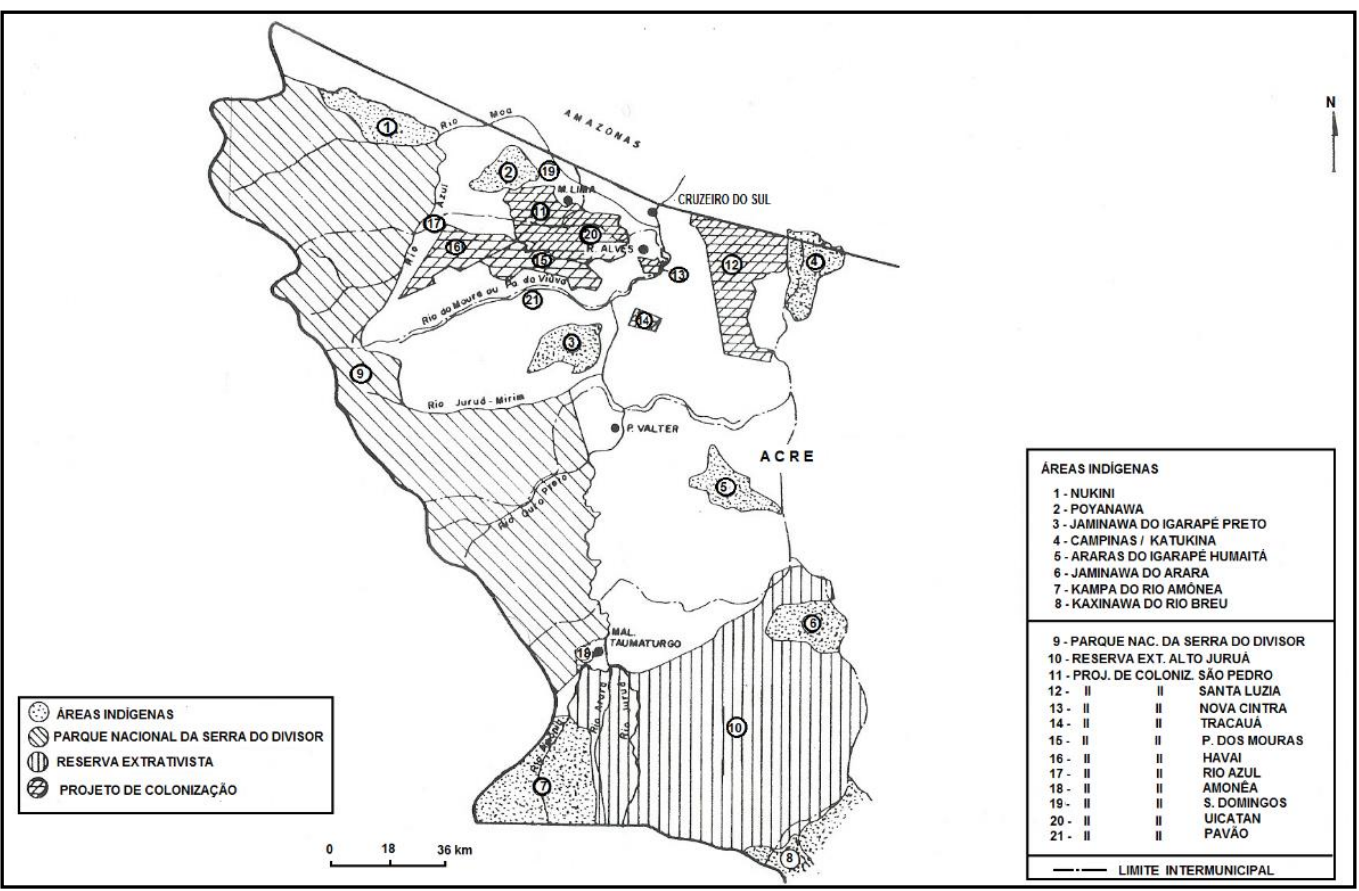

Figura 14: Microrregião de Cruzeiro do Sul - Unidades de Conservação, Áreas Indígenas e Projetos de Colonização (1990) Fonte: SOS AMAZÔNIA, 1998, p. 7 (Encarte 8).

Os principais impactos ambientais registrados, foram provenientes do tipo de atividade econômicas desenvolvidas na microrregião, dentre eles foram destacados: o aumento do desmatamento pela agropecuária, a exploração seletiva de madeira, caça e pesca comerciais. A diminuição da atividade extrativista e a expansão da agriculta e pecuária, principalmente, tem levado a um substancial aumento da conversão de áreas florestais na microrregião, causando perturbações significativas aos ecossistemas ${ }^{570}$.

Dentro do Encarte 5, que tratou do PNSD e sua Zona de Transição, foi realizado avaliação constando o Histórico do Planejamento (conceito de plano de manejo, enquadramento em Fases e metodologias utilizadas); Aspectos Abióticos (clima, geologia, geomorfologia, paleontologia, solos e hidrografia); Caracterização dos Aspectos Naturais (vegetação e fauna); Aspectos Culturais e Históricos; Ocorrência de fogo e fenômenos naturais excepcionais; Atividades no PNSD e seus Impactos

${ }^{569}$ Ibid., p. 10 (Encarte 4).
${ }^{570}$ Ibid., p. 19 (Encarte 4). 
Evidentes; Aspectos Institucionais; Zona de Transição; Declaração de Significância; e por último, Problemáticas.

Neste Encarte, tratou-se longamente das características específicas do clima, geologia, geomorfologia, paleontologia, solos e hidrografia (características abióticas) e também dos tipos de vegetação e animais existentes. O que mais nos chama atenção está na Zona de Transição do Parque, que compreende uma faixa de $10 \mathrm{~km}$ a norte, leste e sul, em território nacional. A faixa limítrofe a oeste do parque, como já mencionamos não foi considerada "zona de transição", por estar situada em território estrangeiro.

Esta zona de transição do parque, abrange as sedes dos municípios de Porto Walter e Marechal Thaumaturgo, os Projetos de Assentamentos Havai, Rio Azul e Amônia, com 66.800 ha, as Áreas Indígenas Nukini/Mõa e parte da Aldeia Ashaninka/Kampa do Amônia, com 47.611 ha, as Glebas Vitória/Redenção no rio Juruá e Arara no rio Amônia, com 22.950 ha, área integral de 12 seringais e trechos de 14 seringais (particulares), e parte da Reserva Extrativista do Alto Juruá ${ }^{571}$.

Também foi realizada a caracterização dos ecossistemas da zona de transição. A classificação fitoecológica, apresentou as características propostas pelo RADAMBRASIL, em 1977: Região Fitoecológica da Floresta Tropical Densa; Região Fitoecológica da Floresta Tropical Aberta; e Região Fitoecológica da Campinarana.

Quanto a Declaração de Significância, o PNSD foi considerado na época o quarto maior parque nacional. E o fato de estar localizado na borda oeste da Bacia Amazônica, zona de transição entre a cordilheira andina e as terras baixas de floresta tropical úmida, faz com que o parque proteja uma diversidade impressionante de habitats, tornando-se de vital importância para a manutenção de uma área de comprovado endemismo e biodiversidade ${ }^{572}$.

Sua proximidade com outras unidades de conservação como a Resex do Alto Juruá, potencializa sua significância na conservação dos ecossistemas amazônicos, possibilitando a existência de um corredor ecológico mais efetivo para o fluxo gênico. $\mathrm{O}$ IBAMA implantou a criação de grandes "corredores ecológicos", englobando unidades de conservação em áreas representativas dos diferentes ecossistemas brasileiros. $\mathrm{O}$ PNSD está inserido no Corredor Oeste da Amazônia, considerado de alta prioridade em termos de conservação da biodiversidade no país ${ }^{573}$.

\footnotetext{
${ }^{571}$ Ibid., p. 224 (Encarte 5).

572 Ibid., p. 233 (Encarte 5).

${ }^{573}$ IBAMA, 1996 apud SOS AMAZÔNIA, 1998, p. 233 (Encarte 5).
} 
Usando a metodologia "Avaliação Ecológica Rápida", os pesquisados que elaboraram o plano de manejo, conseguiram levantar alguns grupos faunísticos, que indicaram alta diversidade (aproximando-se ou excedendo-se dos maiores valores anteriormente conhecidos para a floresta tropical). Como exemplo, podemos citar o registro a presença de 1.233 espécies de animais, 60\% considerados de valor especial para a conservação (76 vertebrados e 14 invertebrados), além de três espécies de aves novas para a ciência (uma de Squamata - animais que fazem parte da classe dos répteis que apresentam como principal característica a presença de escamas no corpo - e inúmeros de invertebrados).

O sexto e último Encarte contemplou a temática de Planejamento do PNSD, onde foi apresentado os objetivos do parque, normas gerais, zoneamento, programas de manejo, e áreas de desenvolvimento.

Os objetivos do Parque, foram os mesmos estabelecidos no Decreto n. 84.017 de 21 de setembro de 1979, que definiu e caracterizou estas unidades: "preservação dos ecossistemas naturais englobados contra quaisquer alterações que os desvirtuem"574. Quanto aos objetivos específicos, foram listados: a proteção da beleza cênica excepcional da área serrana denominada Complexo Fisiográfico da Serra do Divisor; proteção de amostras representativas dos ecossistemas florestais encontrados; preservação da riqueza florística das tipologias vegetais, cujos valores observados estão entre os mais altos já encontrados na Amazônia brasileira; proteção da fauna da região; garantir a conservação e estudo dos elementos da biodiversidade exclusivamente encontradas no parque; proteção da diversidade biológica, atuando como banco genético para a ciência e futuras gerações; proteção dos sítios paleontológicos localizados no rio Juruá e seus afluentes, e proteção da bacia hidrográfica do Alto Rio Juruác ${ }^{575}$.

Quanto as normas gerais de funcionamento do parque, também foi seguido o estabelecido no Decreto n. 84.017 de 1979. Para o PNSD o plano de manejo observou: as atividades humanas permitidas incluem a fiscalização, pesquisa científica, recreação e monitoramento ambiental; a proibição da utilização, perseguição, caça, apanha ou introdução de espécies da fauna e flora silvestre e domésticas, bem como modificações do meio ambiente a qualquer título, à exceção de atividades científicas devidamente autorizadas pelo IBAMA; permissão da visitação pública para propósitos científico,

\footnotetext{
574 BRASIL. Decreto $\mathbf{n}^{\mathbf{0}}$ 84.017, de 21 de setembro de 1979. Aprova o Regulamento dos Parques Nacionais Brasileiros. Brasília: 1979.

${ }^{575}$ SOS AMAZÔNIA, 1998, p. 1-3 (Encarte 6).
} 
culturais, educativos ou recreativos, de acordo com regulamentação específica; permissão para o lixo biodegradável ser enterrado próximo à sede do Parque, e o não biodegradável, gerado ou não no parque, devendo ser recolhido da área; autorização de pesquisa científica pelo IBAMA; proibição de acampamentos e fogueira em qualquer parte do parque; impedimento de abertura de trilhas a não ser as previstas no plano de manejo; qualquer atividade na Zona de Transição deverá ser submetida à Administração do parque e, quando couber, à Superintendência do IBAMA ${ }^{576}$.

Ainda neste Encarte, com objetivo de cumprir os objetivos de unidade de conservação dessa natureza, o Parque foi submetido a um zoneamento, que é obrigatório na realização de um plano de manejo, como já observamos no cap. 2. No zoneamento a área é dividida em zonas com distintos tipos de usos, todos eles indiretos, com diferentes graus de intervenção e proteção. Os critérios utilizados para zonear o PNSD basearam-se nos resultados dos levantamentos de campo para os quais foi utilizada a metodologia "Avaliação Ecológica Rápida". Deste modo, foram considerados critérios ecológicos (riqueza e diversidade de espécies, presença de espécies de valor especial para conservação - raras, ameaçadas, endêmicas, de distribuição restrita e exclusiva); a fragilidade, tamanho e representatividade das tipologias vegetais dentro e forma do parque (grau de primitividade em que se encontram); critérios sócio-econômicos e de uso da terra (como os padrões da ocupação humana da época); e os sistemas de produção presentes na área ${ }^{577}$.

Levando-se em conta tais critérios, foram definidas seis zonas: Intangível, Primitiva, Uso Extensivo, Uso Intensivo, Recuperação, e Uso Especial. Consta no plano de manejo que este zoneamento não é definitivo, ele pode ser modificado quando da elaboração do novo Plano de Manejo - Fase 3, conforme novos conhecimentos sobre o parque $^{578}$.

A Zona Intangível do parque ficou localizada no Setor Norte, ocupando 135.000 hectares, correspondendo a $16 \%$ da área total da unidade. Essa área engloba a Serra da Jaquirana, a Serra do Môa e uma faixa descontínua ao longo do sopé oriental das duas serras e toda a área Oeste destas. O objetivo dessa zona é propiciar o mais alto grau de proteção para o ecossistema de Floresta Ombrófila Densa Sub-Montana dos Baixos Platôs da Amazônia, na parte em que recobre a Serra da Jaquirana e Serra do

\footnotetext{
576 Ibid., p. 4 (Encarte 6).

577 Ibid., p. 8 (Encarte 6).

${ }^{578}$ Ibid., p. 8 (Encarte 6).
} 
Môa, para o ecossistema de Floresta Ombrófila Densa nos Interflúvios Colinosos dos Baixos Platôs da Amazônia, e para o ecossistema de Floresta Ombrófila Aberta de Palmeiras sobre Depósitos Coluviais. Toda esta área, apresenta o mais alto valor biológico no Parque e se encontra em condições próximas da primitiva, com nível baixo de alteração das suas condições naturais. Essa área também protegerá várias espécies de animais e plantas de valor especial para conservação ${ }^{579}$ (fig. 15).

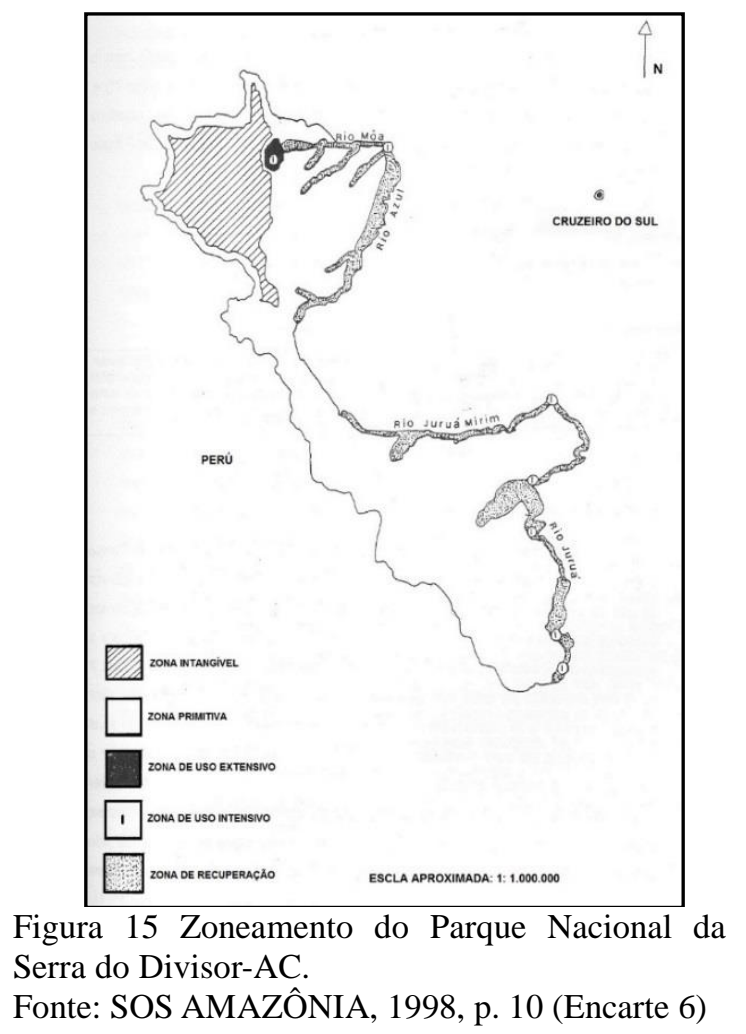

A Zona de Uso Extensivo, foi escolhida por sediar áreas com maior potencial para as atividades de visitação, ideal para a realização de atividades de turismo ecológico e recreação orientada. Ela está localizada no Setor Norte do parque e ocupa aproximadamente 7.000 hectares. Engloba o bordo oriental da Serra da Jaquirana denominada localmente de "Pé da Serra", o conhecido Igarapé do Amor e a trilha Anil até a altura da Cachoeira do Pedernal. Esta área foi considerada a mais bela em termos de beleza cênica, sendo possível observar o canyon formado pelo rio Môa ao entrar na Serra da Jaquirana, com seus paredões rochosos, e a caminhada até o topo do Morro Queimado (duração de 3 horas), que oferece uma vista panorâmica do Parque ${ }^{580}$.

${ }^{579}$ Ibid., p. 11-12 (Encarte 6).

${ }^{580}$ Ibid., p. 23 (Encarte 6). 


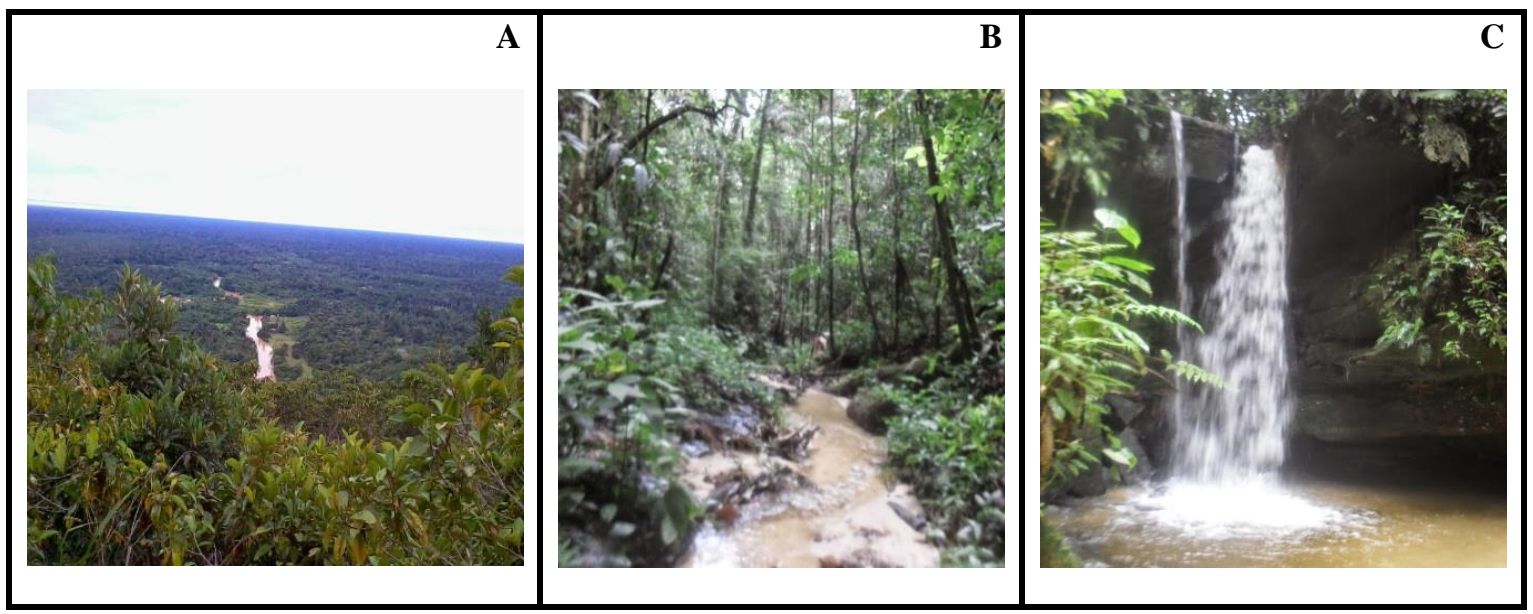

Figura 16 Vista Parcial do Parque Nacional da Serra do Divisor-AC. A- Visão do Topo da Serra; B Região de Nascente; e C - Cachoeira Ar Condicionado

Fonte: RAMOS, Paloma de Oliveira, 2014.

Quanto a Zona de Uso Intensivo, foram escolhidos pontos que pudessem fornecer apoio aos visitantes e ao mesmo tempo à fiscalização. Situada no Sopé da Serra da Jaquirana na localidade denominada Pé da Serra e na foz do igarapé Apuí, no rio Juruá Mirim ${ }^{581}$.

Por fim, a Zona de Recuperação, constituem basicamente áreas de várzeas, onde vivem a população do parque, cerca 552 famílias. As áreas desta zona são descontínuas, e totalizam mais de 78.000 hectares (33.112 ha no Setor Norte e 45.397 ha no Setor Sul). O objetivo principal desta zona é controlar a degradação das áreas ocupadas pelo homem, e implementar um manejo adequado para sua recuperação.

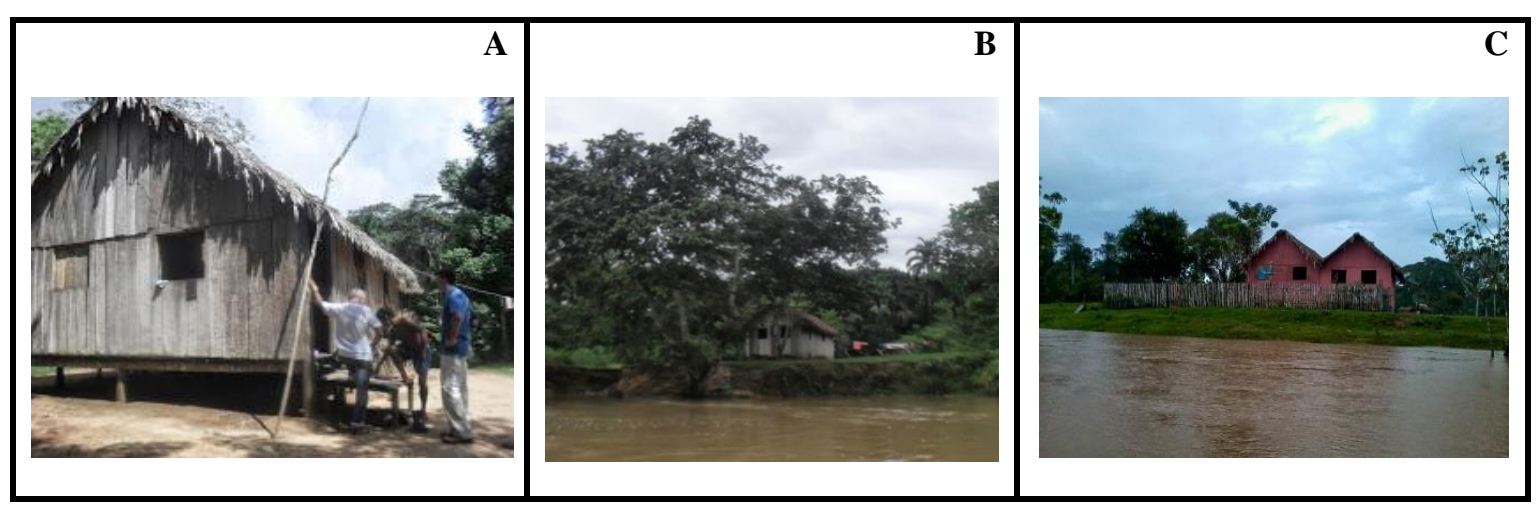

Figura 17 Moradias típicas do PNSD-AC. A, B e C-Casas das famílias que residem no parque. Fonte: RAMOS, Paloma de Oliveira, 2014.

A vegetação das áreas de várzea foi classificada como de Significância Muito Alta para a conservação, pela riqueza de espécies encontradas. Nestas áreas foi

${ }^{581}$ Ibid., p. 25 (Encarte 6). 
observado em muitos trechos, que a fauna já está empobrecida quando se trata de grandes mamíferos e da avifauna ${ }^{582}$.

As atividades humanas têm causado ameaças a integridade ecológica do local. Isso foi verificado pela extração de madeira, atividade agropecuária, caça, exploração de produtos florestais não madeireiros, pesca, presença de habitações, criação de gado, porcos, galinhas, carneiros e cabras, dentre outros ${ }^{583}$.

\subsection{Algumas Avaliações sobre o Processo de Criação do PNSD, Elaboração e Implantação do Plano de Manejo.}

Como vimos no decorrer deste capítulo, a área do PNSD não foi escolhida aleatoriamente, foram vários os estudos que apontaram a região como propícia para a criação de uma área protegida. Apesar de boa parte dos primeiros estudos basearem-se em levantamentos já realizados por pesquisadores de outros países, os demais foram aos poucos acrescentando informações importantes para a proposta de criação de uma unidade de conservação no sudoeste da Amazônia brasileira.

O Relatório do IBDF de 1976, intitulado "Uma Análise de Prioridade para a Conservação da Natureza na Amazônia", seguiu as recomendações feitas pelo II PND, que declarava que o desenvolvimento do país deveria ocorrer sem a degradação da qualidade de vida e dos recursos naturais. As dificuldades não foram poucas para a elaboração deste Relatório, haja vista que, além da imensidão territorial, nos anos 1970, era significativa a falta de conhecimento sobre a região amazônica.

O Projeto RADAMBRASIL de 1977 (Javari/Contamana), foi relevante, ao indicar a Serra do Divisor como área a ser protegida. Este projeto fazia parte da política de integração nacional, e um de seus objetivos era fazer o reconhecimento dos recursos naturais na Amazônia que, por suas características peculiares, dificultava os trabalhos de campo mais minuciosos. Nesse sentido, a pesquisa de campo se deu de forma generalizada, com a extrapolação dos dados verificados nos pontos de amostras.

Apesar das dificuldades mencionadas no próprio relatório do RADAMBRASIL, as características da região da Serra do Divisor foram melhor explicitadas, quando comparadas ao Relatório do IBDF. Sendo possível fazer uma avaliação das principais características fisiográficas da área (geologia, geomorfologia,

\footnotetext{
582 Ibid., p. 29 (Encarte 6).
}

${ }^{583}$ Ibid., p. 29 (Encarte 6). 
pedologia e flora), mesmo que na escala de 1:250.000. Além disso, o RADAMBRASIL apresentou uma simulação do uso potencial da terra, onde indicou a criação de uma Reserva Florestal na Serra do Divisor. O relatório afirmava que, pelas características da região também poderia ser implantado um Parque Nacional. Entretanto, como a existência de moradores e a atividade extrativa já era uma realidade, concliu que a categoria de Floresta Nacional se encaixaria melhor, tornando possível a conciliação da presença de moradores com a preservação das riquezas naturais do lugar.

Em 1982, o "Plano do Sistema de Unidades de Conservação do Brasil PSUC" (II Etapa) veio reforçar a criação legal de uma área protegida para a região sudoeste da Amazônia. Neste documento - que apresentava uma ficha de análise para cada área proposta, com as informações disponíveis sobre ela - também foi indicada a criação de um parque no Acre: "O Parque Nacional da Serra do Divisor". Na ficha constam as características biofísicas, socioculturais, a proposta de uma minuta do Decreto de Criação do Parque e, ainda, um mapa da área proposta com sua rede hidrográfica.

Podemos assinalar que o PSUC instigou de forma intensa a criação e legalização do Parque na Serra do Divisor. Porém, não devemos esquecer que este documento, assim como os demais, não apresentou um conjunto significativo de informações sobre a população local. O que dificultava a definição mais eficiente do tipo de unidade a ser criada.

Nas entrevistas realizadas com os pesquisadores responsáveis pela elaboração do plano de manejo do Parque, observamos que, em geral, eles se manifestaram favoráveis à criação de um parque na região. Porém, muitos se manifestaram acerca dos problemas de manutenção do Parque e, em especial, sobre sua criação, sem que tivesse sido feita uma consulta à população local.

Para o professor Moisés Barbosa de Souza, que participou da elaboração do plano de manejo, a área onde foi indicada a criação do Parque foi uma decisão acertada:

Quanto ao local de criação do Parque, acho que foi acertada. A área deve ser conservada mesmo, pois há uma enorme biodiversidade, pelo menos para anfíbios, penso que uma das maiores ou a maior do mundo para aquela localidade. Hoje eu não sei como a área se encontra, fazem treze a quatorze anos que estive lá, quando coletei dados para o meu doutorado (diversidade de anfíbios). Acho que continua com todos os problemas que existiam antes, primeiro de tudo todas as famílias continuam lá dentro, não existe fiscalização. O IBAMA ou a Fundação Chico Mendes, não sei quem está responsável por isso agora, mas o fato é que seu quadro funcional é muito pequeno. O cara vai lá uma vez por mês, as famílias continuam lá dentro 
caçando, pescando, extraindo madeira, então eu não posso dizer que a coisa está funcionando bem! Acho que continua do mesmo jeito que antes, o fato é que o governo cria as áreas, mas na maioria não dá condições de funcionamento, a maioria das reservas que você vê, têm problemas. Trabalhei na maioria das áreas de conservação criadas no Acre, depois você volta e elas estão do mesmo jeito do momento da criação, não se tem uma continuidade dos trabalhos ${ }^{584}$.

$\mathrm{Na}$ opinião do professor Elder Ferreira Morato, a área da Serra do Divisor deveria mesmo ser criada, por várias razões. Durante sua entrevista, ele comenta:

\begin{abstract}
Antes de mais nada, não esquecendo que sou um biólogo, hoje estamos vivendo um outro momento de discussões de exploração de gás e petróleo que inclusive afeta algumas áreas do parque, então na minha opinião isso tinha que acontecer, essa criação do parque naquela região. Naquele momento ele foi criado em uma esfera federal, mas eu acho que ele deveria ter sido contemplado de forma que abrangesse o interesse da população local. A própria Lei do SNUC quando lemos os artigos, a gente não entende porque não abrange as populações vigentes naquela área. É claro que lá não é uma região que se tenha uma vocação para o extrativismo, está muito longe disso. Mas assim, as nossas leis ainda têm lacunas e falhas. Na realidade, esse foi o grande problema já que as pessoas que falam muito nessa problemática, mesmo agora, a unidade de conservação que estamos falando é uma Unidade de Conservação de Uso Indireto onde já existia uma população e isso tem acontecido nas unidades como um todo. Não só no Brasil, mas em todas, de forma geral. E na Amazônia as nossas unidades de conservações são imensas, e são áreas que a geografia não favorece a ocupação, mas existem áreas como a do Parque Nacional da Serra do Divisor que são altamente suscetíveis, de fácil navegação, diferentemente de outras como o Pico da Neblina, o Monte Roraima, inacessível até para aqueles que querem fazer pesquisas. Não é o nosso caso, pois ele é altamente acessível ${ }^{585}$.
\end{abstract}

O gestor da SOS Amazônia, Miguel Scarcello, também relata que, quando da criação do Parque, a população residente na região não foi consultada e que, na época, não havia essa exigência. No entanto, segundo o Scarcello "a criação não foi feita de maneira aleatória, não foi feita só em gabinete, teve toda uma base conceitual de pesquisa bem fundamentada e que foi muito significativa".

Havia uma iniciativa do governo federal muito antiga de estudar as áreas prioritárias de conservação na Amazônia, com estudo feito pelo antigo IBDF e FAO, isso subsidiou uma série de políticas de governo, eu creio que tendo em vista as pressões contra os desmatamentos que ocorreu na década de $1980^{586}$.

\footnotetext{
${ }^{584}$ Entrevista concedida à autora pelo Biólogo Moisés Barbosa de Souza, professor da Universidade Federal do Acre, em Rio Branco, em 31.03.2014.

585 Entrevista concedida à autora pelo professor de Ecologia Elder Ferreira Morato, da Universidade Federal do Acre, Elder Ferreira Morato, em Rio Branco, em 02.04.2014.

${ }^{586}$ Entrevista concedida à autora pelo Geógrafo Miguel Scarcello, gestor da SOS Amazônia, em Rio Branco, em 15.01.2014.
} 
O estudo apontado por Scarcello foi o relatório publicado pelo IBDF em 1976, já mencionado em nosso trabalho como o primeiro estudo da região amazônica que aponta para a possibilidade de criação de um parque no sudoeste da Amazônia que, depois se concretizaria com o PNSD.

Como vemos, Scarcello ressalta que, na época, não se levava muito em consideração o número de famílias que moravam na região, um aspecto considerado por ele relevante, pois até hoje as famílias continuam no local, o que torna a situação complicada, tanto para as famílias quanto para o parque.

No relato da bióloga e ecóloga, Lindomar Soares Resende, o parque foi criado através de um decreto, sendo anterior ao SNUC:

O processo de criação não cumpriu todas essas etapas que o SNUC orienta, então ele foi uma criação mesmo de gabinete, ele não teve todo esse processo onde a sociedade pode opinar, onde a sociedade participa das audiências públicas e ajudam no processo de criação e nas decisões. Não cumpriram essas etapas por conta que a legislação não existia ainda, basearam-se apenas em referências, pesquisas e estudos ${ }^{587}$.

Já para o professor Elder Ferreira Morato, o parque foi criado por dois motivos:

Lembrando que isso e uma leitura minha! Foi um período que o governo federal estava criando um número muito grande de unidades de conservação, não só na Amazônia mas em todo país. Se a gente acompanhar, existem dados sobre isso. Não foi de uma forma continua, existem momentos na história do Brasil que houve picos de criações. Então essa época de criação coincidiu com esses picos. O outro motivo é um motivo de natureza biológica, pois o parque está localizado em uma área bastante privilegiada em termos do ponto de vista paisagístico, uma região relativamente alta e de uma alta biodiversidade, muito peculiar do ponto de vista biológico, mesmo sabendo que há famílias naquela região. O que não é novidade, pois a maioria das unidades de conservações do Brasil é criada onde já existem populações, ribeirinhos, indígenas e outros ${ }^{588}$.

Como vimos, em 1989 foi publicado o Decreto de criação do PNSD, mas os trabalhos de elaboração do Plano de Manejo só se iniciaram em 1995, por iniciativa de uma organização não governamental, a SOS AMAZÔNIA. De acordo com o Decreto que regulamentou os Parques Nacionais brasileiros, de 1979, o órgão responsável por estas áreas deveria providenciar, no prazo máximo de cinco anos, a elaboração do seu

\footnotetext{
${ }^{587}$ Entrevista concedida à autora pela bióloga e ecóloga Lindomar Resende, professora da Universidade Federal do Acre (Campus de Cruzeiro do Sul), em Cruzeiro do Sul, em 23.02.2014.

${ }^{588}$ Entrevista concedida à autora pelo professor de Ecologia Elder Ferreira Morato, da Universidade Federal do Acre, Elder Ferreira Morato, em Rio Branco, em 02.04.2014.
} 
Plano de Manejo. Porém, isso não aconteceu para o PNSD, o plano só foi publicado em 1998, nove anos após sua criação, e não foi elaborado exclusivamente pelo IBAMA.

Também, com base no Decreto de 1989, o plano de manejo, deveria sofrer revisão periódica a cada cinco anos, o que infelizmente não vem acontecendo com o plano do PNSD. Já se passaram dezessete anos, agora em 2015, da sua publicação e nenhuma revisão aconteceu.

Nas entrevistas com os profissionais que participaram na elaboração do plano de manejo, também foi perguntado sobre a eficácia do Plano nos mais de vinte anos de existência do Parque.

O professor Marcos Silveira argumentou que

... nos primeiros anos após a aprovação do plano de manejo, podemos dizer que funcionou muito bem. Em várias áreas do conhecimento foram elencados alguns projetos a serem desenvolvidos nas comunidades. Eu participei de um projeto de regeneração das espécies que ocorrem na área de várzea, onde a criação de porcos é danosa para sua regeneração. Mas, outras atividades de pesquisa que foram propostas nunca tiveram uma resposta positiva de realização. Teve a parte de educação ambiental que foi trabalhada por alguns pesquisadores, inclusive a S.O.S Amazônia foi uma pioneira em incentivar esses projetos na área de Educação Ambiental. Já está com cinco anos que eu não vejo nem uma ação desse tipo na região do Parque. Mas eu acho que essa eficácia do plano de manejo, não é uma eficácia completa, hoje ainda ouvimos falar de retirada de madeira ilegal, de caça. Tráfico, por se tratar de uma zona fronteiriça, é muito comum vermos canoas deixadas às margens dos rios por traficantes peruanos que acessam a região com grande facilidade. Então falta ainda uma ação mais forte de coibição do exército. No alto da Serra mesmo a gente não vê nem um tipo de fiscalização ${ }^{589}$.

Para o coordenador geral do Plano de Manejo, Miguel Scarcello,

De fato o parque ainda não está cumprindo o seu papel. De um lado, por si só, por ser um parque, ele já estabelece uma certa proteção e dificulta que haja uma ocupação e se promova o desmatamento de maneira descontrolada. Mas, por outro lado, ele ainda não tem implementado o seu plano de manejo, que ainda está engavetado. São poucas as iniciativas contidas no plano que estão sendo realizadas. Isso acaba impossibilitando que o parque atinja seus objetivos de maneira integral, até mesmo no trato com as famílias. Mesmo não estando contidas no plano, a questão com as famílias, mais a lei atual do sistema de unidades de conservação, já possibilita que essa situação seja tratada e esses problemas que as famílias encontram sejam de fato conduzidos a uma solução. Então, por essa dificuldade dos gestores do parque em cumprir o seu papel, o funcionamento do parque acaba tendo pouca efetividade ${ }^{590}$.

${ }^{589}$ Entrevista concedida pelo Ecólogo Marcos Silveira, professor da Universidade Federal do Acre, à autora, em Rio Branco, em 11.07.2014.

${ }^{590}$ Entrevista concedida à autora pelo Geógrafo Miguel Scarcello, gestor da SOS Amazônia, em Rio Branco, em 15.01.2014. 
Segundo a professora Lindomar Soares Resende, o plano ficou de fato paralisado, tanto nas ações propostas, como também em sua revisão:

... não vejo pesquisas voltadas para o desenvolvimento do parque, não vejo trabalho de educação ambiental, apesar de ser uma área que as pessoas, aqui no município tem interesse em visitar em feriados e finais de semanas. Mas, como a Unidade de Conservação que deveria funcionar, não funciona. E não tem nem um trabalho que dê uma visibilidade, que a gente possa reconhecer e pôr em funcionamento o plano de manejo. Acho que nem foi feita a revisão, como a lei recomenda, foi elaborado e deve estar no escritório. Se alguém quiser conhecer, pode ir lá que ele deve estar lá. O parque não está aberto para a comunidade, se está, a gente não enxerga, os órgãos públicos são limitados em suas atuações, por falta de recursos humanos, infraestrutura, ou por uma falta de comprometimento dos funcionários ${ }^{591}$.

Durante a entrevista com o professor Moisés Barbosa de Souza, ele acrescentou:

Eu voltei ao Parque em 2000-2001, para fazer meu projeto de doutorado. Já temos praticamente quatorze anos. Mas, pelo que ouço de amigos que acompanham a área, acredito que não mudou muito, os problemas continuam. Acredito até que nem uma equipe foi lá para fazer um acompanhamento ou um levantamento do que mudou ou do que está acontecendo. Eu não sei como está a população que lá se encontra vivendo, qual o número de famílias residentes no Parque. Então, como falei anteriormente, o governo cria, mas não dá o acompanhamento dos trabalhos que existem. São geralmente alguns pesquisadores que trabalham de forma esporádica, de acordo com seus interesses e dentro de suas áreas de pesquisas, sem que haja uma conexão, muitas vezes, com o projeto do governo e nada mais que isso. Os governantes fazem muito pouco. Essa é minha opinião ${ }^{592}$.

Leôncio Cerqueira de Menezes, Guia nos levantamentos de campo do PNSD (na época Assessor do Sindicato dos Trabalhadores de Cruzeiro do Sul e Coordenado do Conselho Nacional dos Seringueiros), também se mostrou bem desacreditado. Para ele:

O plano está parado. Não foi feita nem a revisão do plano. O que foi colocado em prática foi a construção do prédio do IBAMA, no pé da Serra. E depois, na comunidade São Salvador, foi feita uma estrutura para ser a sede do parque e hoje se tornou alojamento do Exército ${ }^{593}$.

Como podemos notar, a maioria dos entrevistados concorda que o Plano de Manejo do PNSD infelizmente ficou parado depois de sua publicação, em 1998. O que

\footnotetext{
${ }^{591}$ Entrevista concedida à autora pela bióloga e ecóloga Lindomar Resende, professora da Universidade Federal do Acre (Campus de Cruzeiro do Sul), em Cruzeiro do Sul, em 23.02.2014.

592 Entrevista concedida à autora pelo Biólogo Moisés Barbosa de Souza, professor da Universidade Federal do Acre, em Rio Branco, em 31.03.2014.

593 Entrevista concedida à autora pelo Guia Leôncio Cerqueira de Menezes, Assistente técnico em extensão rural (contrato provisório pela SOS AMAZÔNIA, em Cruzeiro do Sul, em 24.04.2014.
} 
nos revelar a necessidade de um olhar mais cuidadoso dos órgãos responsáveis pelas unidades de conservação no país. 


\section{Considerações Finais}

Este trabalho teve como objetivo o entendimento do processo de escolha e criação do Parque Nacional da Serra do Divisor, localizado na parte mais ocidental do Acre e do Brasil, no período de 1976 a 1998. Para tanto, fez-se necessária, inicialmente, uma análise do processo de criação das primeiras áreas protegidas no mundo e também no Brasil.

Ao longo do nosso trabalho pudemos observar que o principal objetivo da criação das áreas protegidas no mundo foi a manutenção dos ambientes naturais, com o mínimo impacto ambiental. Como ponto de partida, os vários países adotaram o modelo concebido nos Estados Unidos, com a criação do Parque Nacional de Yellowstone (1872), que a literatura tem apontado como divisor de águas, quando se trata de proteção dos recursos naturais. Do século XIX até meados do século XX, o Parque Nacional era o único modelo de área protegida e foi se espalhando pelo mundo, porém, com características muitas vezes diferenciadas de um país para outro. Geralmente estes parques tinham em comum o objetivo de resguardar ambientes "virgens", sendo permitido apenas a visitação com fins recreativos.

Com o avanço da urbanização e a crescente destruição dos recursos naturais (fauna e flora) em vários lugares do mundo, começaram a surgir outras categorias de áreas protegidas, com objetivos diferentes dos parques nacionais. Como exemplo, podemos citar, os refúgios de vida silvestre, os monumentos naturais, e as reservas florestais.

Para a implantação de debates sobre a questão da preservação e o estabelecimento de uma padronização dos diferentes tipos de áreas protegidas, foi fundamental a atuação da União Internacional para a Conservação da Natureza e dos Recursos Naturais, fundada no âmbito da UNESCO em 1948. Desde a sua criação a UICN, vem atuando em defesa da natureza, estimulando a criação de áreas protegidas em todo o mundo.

Em 1960, a UICN criou a Comissão Mundial de Áreas Protegidas, que passou a realizar os congressos mundiais de parques nacionais a cada dez anos. Foi nestes congressos que foram estabelecidas e aperfeiçoadas categorias para as áreas protegidas, de acordo com os objetivos de manejo que se desejava para cada tipo. 
Com a definição das várias categorias, foi possível a criação de diferentes tipos de áreas, com objetivos e manejo específicos. Inclusive áreas que permitiam a presença de moradores em seu interior, como as Reservas Extrativistas, última categoria incluída na classificação da UICN, em 1994.

Ficou definido então, a nível internacional, um sistema de classificação que agrupou seis categoriais: Reserva Natural Restrita/Área Silvestre; Parque Nacional; Monumento Natural; Santuário de Vida Silvestre; Paisagem Terrestre/Marinha Protegida; e Área Protegida com Recursos Manejados. Este sistema vigora até hoje.

No Brasil, as primeiras unidades de conservação foram criadas no século XX, seguindo o modelo dos primeiros parques norte-americanos, que tinham como objetivo a proteção das belezas cênicas. Entre 1937 até 1961 foram criadas dezessete unidades, a maioria na categoria Parque Nacional, correspondendo à proteção de uma superfície de $28.957,88 \mathrm{~km}^{2}$.

No entanto, diferentemente das áreas protegidas norte-americanas, localizadas em regiões com pouca ou nenhuma alteração humana, em nosso país, elas acompanharam o processo de ocupação, que foi seguido da destruição dos recursos naturais. Começando pelo litoral, primeira região ocupada pelos colonizadores, seguindo para o interior (porção Oeste), acompanhando o fluxo da frente pioneira.

Tanto as primeiras unidades de conservação, quanto os primeiros instrumentos de regulamentação dos recursos naturais no Brasil, tiveram como referência os movimentos ambientais internacionais, dos quais o país participou. Após a Convenção de Londres (1933), por exemplo, o governo brasileiro aprovou o primeiro Código Florestal, em 1934. Também neste ano foi realizada, na cidade do Rio de Janeiro, a primeira Conferência Brasileira de Proteção à Natureza. Entre os objetivos dessa Conferência estava a tentativa de pressionar o governo a cumprir algumas medidas conservacionistas aprovadas pelo Código Florestal, com destaque para a criação de um sistema de parques nacionais.

Em 1946, o Brasil reconheceu os regulamentos da Convenção Pan-Americana (1940), ratificada somente em 1966. A partir daí, o país adotou quatro categorias de áreas protegidas/unidades de conservação: os Parques Nacionais, as Reservas Nacionais, os Monumentos Naturais e as Reservas de Região Virgem.

Nos anos 1950, o governo Juscelino Kubitschek, além de seu ambicioso "Plano de Metas", que visava o desenvolvimento da economia do país, foi efetivado o processo de ocupação do interior do país, com a construção da nova capital federal na região 
Centro-Oeste. Então, um grupo de conservacionistas, preocupados com os impactos ambientais resultantes do Plano de Metas, criou a Fundação Brasileira para Conservação da Natureza (1958), que teve grande importância na luta pela criação de unidades de conservação nas décadas seguintes.

Dentre as preocupações do governo militar (1964 a 1985), destacamos o processo de ocupação da região amazônica, considerada "inabitada" naquele período. Castelo Branco lançou a "Operação Amazônia” nos anos 1960, definindo estratégias para a introdução de um modelo de desenvolvimento econômico na Amazônia Legal. Não podemos esquecer que o governo de Médici também deu prioridade para o desenvolvimento das regiões Norte e Nordeste, que tinha como lema "Integrar para não Entregar".

As consequências ambientais resultantes de um processo de ocupação a qualquer custo, chamou atenção nacional e internacional quanto a defesa dos recursos naturais naquela região. Estudos realizados pelo próprio governo revelaram a necessidade de se proteger parte da biodiversidade da região, através da criação de áreas protegidas. Neste interim, o país implantou setenta e sete unidades de conservação, cobrindo cerca de $150.000,00 \mathrm{~km}^{2}$. De toda a superfície protegida, durante o período militar, 78,4\% situava-se em terras amazônicas. Consideramos que este direcionamento resultou das críticas nacionais e internacionais dirigidas ao modelo de ocupação que estava sendo implantado na Amazônia.

Após a ditadura militar, as políticas de proteção dos recursos naturais deram seguimento, e no espaço de tempo de 14 anos (1986 a 2000) registrou-se no país a criação de noventa e duas unidades de conservação, cobrindo mais de $200.000,00 \mathrm{Km}^{2}$, a maioria situada na região amazônica. Por fim, em 2000, depois de muitos debates, críticas e alterações foi aprovado o Sistema Nacional de Unidades de Conservação SNUC, que estabeleceu critérios e normas para a criação, implantação e gestão das áreas protegidas.

Ao analisarmos mais de perto as políticas federais destinadas à ocupação da região amazônica pelos governos militares, nos anos 1960 e 1970, ficou claro que os incentivos fiscais e creditícios para a implantação dos grandes projetos agropecuários e/ou minerais, estimularam a destruição das florestas, a concentração de terras e a expulsão das populações extrativistas e indígenas, acarretando uma série de conflitos.

Em um contexto de grande destruição das florestas, a luta dos extrativistas pela manutenção das mesmas foi intensa, e trouxe consequências sangrentas na região. 
Depois da morte Chico Mendes, em 1988, encomendada por fazendeiros no Acre, a situação ganhou repercussão mundial. O que justificou a realização no Brasil da Conferência das Nações Unidas sobre Meio Ambiente e Desenvolvimento, em 1992.

A luta dos seringueiros para conter o desmatamento no Acre, por meio dos “empates", pautava-se na própria sobrevivência, tendo em vista, que era da floresta, que eles tiravam seu sustento. Neste sentido, não se tratava da uma ação em defesa do meio ambiente, e sim de uma questão agrária.

Porém, ao se apresentarem como guardiões da floresta, acabaram assumindo que a missão dos seringueiros era defender a floresta, dentro de uma ótica preservacionista. Mas, antes de morrer, o próprio Chico Mendes afirmou que, naquele momento, a palavra meio ambiente nem existia no vocabulário deles. Também vimos que nem todos os seringueiros consideravam válida a adesão ao discurso ambiental.

A luta dos seringueiros acreanos teve seus frutos. No palco dos conflitos entre seringueiros e os "novos" donos da terra, foram criadas três unidades de conservação já na década de 1980. E, na década de 1990, foram estabelecidas as primeiras Reservas Extrativistas do Brasil, classificadas como unidades de conservação de uso sustentável.

Como vimos, até 2012, o Estado do Acre possuía dezessete unidades de conservação, três de proteção integral e quatorze de uso sustentável, cobrindo cerca de $51.982,73 \mathrm{~km}^{2}$, ou seja, $31,65 \%$ do território.

As recomendações feitas no IV Congresso Mundial de Parques Nacionais (1992), era que se protegesse $10 \%$ do território de todos os países até o ano de 2000. Enquanto Estado, o Acre ultrapassou esta meta, com mais de 30\%, em 2012. O território brasileiro como um todo, conseguiu implantar, até o ano de 2000, mais de 90 unidades de conservação federais, cobrindo uma superfície de 402.836,60 km², representando apenas $4,73 \%$ do território. Vale destacar, que neste percentual não foram incluídas as unidades de conservação de âmbito estadual e municipal.

Por fim, em relação ao processo de escolha da área e a criação do Parque Nacional da Serra do Divisor, no Acre, as informações levantadas nos conduziram à conclusão de que a região do PNSD não foi escolhida de forma estocástica. Foram realizados vários estudos, entre 1976 e 1982 (Relatório do IBDF - 1976: "Uma Análise de Prioridade para a Conservação da Natureza na Amazônia"; Projeto RADAMBRASIL, vol.13 - 1977; II Etapa do Plano Sistema de Unidades de Conservação do Brasil - 1982), que apontavam a região como propícia a criação de uma unidade de conservação. 
E quanto ao Plano de Manejo do Parque, a maioria dos especialistas que fizeram parte da sua elaboração e foram por nós entrevistados, se manifestaram favoráveis à criação do PNSD, mas também criticaram a forma como o parque foi criado, sem consulta à população local. Neste contexto, não se podia esperar que o Plano de Manejo tivesse cumprido seus objetivos de gestão.

Segundo os especialistas, poucos dos projetos planejados para o PNSD foram implantados. A grande maioria considera que o Plano de Manejo está engavetado, impossibilitando que o parque cumpra e atinja seus objetivos de manejo integral. Enumeraram, assim, muitos problemas observados no Parque: o destino das populações residentes continua incerto; a falta de fiscalização é um agravante, por se tratar de uma grande área de fronteira com o Peru (com cerca 8.430,12 km², o parque possui apenas um agente do ICMbio para monitorar todas as atividades do parque); nem mesmo a visitação está aberta, o que contraria um dos propósitos dos parques nacionais, que é o turismo. Para a realização de pesquisas é necessário enviar um projeto para o ICMbio e, só após a aprovação é que professores, cientistas e alunos podem entrar, levando consigo a carta de autorização com período de validade e atividades que poderão ser realizadas.

Segundo os entrevistados, o governo federal criou a unidade, mas não dá apoio nem acompanha as atividades dentro do Parque. Apenas alguns pesquisadores trabalham de forma esporádica, de acordo com seus interesses e desenvolvimento de suas pesquisas. Para nós, esta situação aponta uma necessidade que a maioria das Unidades de Conservação do país têm, de serem melhor geridas pelos órgãos responsáveis. 


\section{Fontes}

\section{- Fontes Documentais}

PATRIMÔNIO HISTÓRICO E CULTURAL DO ACRE. Biografia dos Governadores Acre. Fundação Elias Mansour, 2014.

FUNATURA. Currículo. (encaminhado via e-mail), abril de 2013.

ICMBio. Instituto Chico Mendes de Conservação da Biodiversidade. Plano de Manejo - Estação Ecológica Rio Acre. Brasília: ICMBio, WWF, SOS AMAZÔNIA, 2010.

ICMBio. Plano de Manejo das Florestas Nacionais do Macauã e de São Francisco. v. 1. Diagnóstico e Caracterização. Sena Madureira-AC: ICMBio, 2009.

IBAMA. Plano de Manejo Reserva Extrativista Chico Mendes. Xapuri-AC: MMA, IBAMA, DISAN, 2006.

VERÍSSIMO, Adalberto; SOUZA Jr., Carlos, SALOMÃO, Rodney. Identificação de Áreas com Potencial para a criação de Florestas Estaduais no Estado do Acre.

Relatório Final. Belém: IMAZON e Governo do Estado do Acre, 2002.

MMA/IBAMA. Plano de Manejo do Parque Nacional do Araguaia-TO. BrasíliaDF: Ministério do Meio Ambiente/Instituto Brasileiro do Meio Ambiente e dos Recursos Naturais Renováveis, 2001.

SOS AMAZÔNIA. Plano de Manejo do Parque Nacional da Serra do Divisor. Rio Branco-AC: SOS AMAZÔNIA, The Nature Conservancy, IBMA, USAID, 1998 (Fase 2).

Boletim Informativo FBCN, n. 1, Rio de Janeiro, 1996.

ESTATUDO SOCIAL ASSOCIAÇÃO S.O.S AMAZÔNIA. Rio Branco-AC: Cartório de Registros de Títulos e Documentos de Registro Civil das Pessoas Jurídicas, 18 de janeiro de 1996.

FUNATURA - Fundação Pró-Natureza. Sistema Nacional de Unidades de Conservação (SNUC): aspectos conceituais e legais. Brasília: IBAMA/FUNATURA, 1989.

PÁDUA, Maria Tereza Jorge; PORTO, Eduardo Lourenço Rocha; BORGES, Gabriel Cardoso; e BESERRA, Margarene Maria Lima. Plano do Sistema de Unidades de Conservação do Brasil (II Etapa). Brasília: IBDF/FBCN, 1982.

IBDF/FBCN. Plano de Manejo - Parque Nacional de Sete Cidades. Brasília: IBDF/FBCN, 1979

PÁDUA, Maria Tereza Jorge; PORTO, Eduardo Lourenço Rocha (coord.). Plano do Sistema de Unidades de Conservação do Brasil. Brasília: IBDF, FBCN, 1979. IBDF/WWF. Plano de Manejo - Parque Nacional da Amazônia (Tapajós). Brasília: IBDF/WWF, 1978.

WETterberG. G. B. e PÁDUA, M. T. J. Preservação da Natureza na Amazônia Brasileira: situação em 1978. Brasília: IBDF, PNUD, FAO, 1978 (PNUD/FAO/IBDF/BRA-76/027, Série Técnica No 13).

CNBB-CEP. Pastoral da Terra - posse e conflitos. Estudos da CNBB-CEP, ed. $2^{\text {a }}$. São Paulo: Edições Paulias, 1977.

BRASIL. Departamento Nacional da Produção Mineral. Projeto RADAMBRASIL. Folhas SB/SC. 18 Javari/Contamana; geologia, geomorfologia, pedologia, vegetação e uso potencial da terra. Rio de Janeiro, 1977. 
WETTERBERG, G. B.; PÁDUA, M. T. J.; CASTRO, C. S.; e VASCOCELlOS, J. M. C. Uma Análise de Prioridades em Conservação da Natureza na Amazônia. Brasília: IBDF, PNUD, FAO, 1976 (Projeto de Desenvolvimento Florestal e Pesquisa Florestal, Série Técnica $N^{\circ} 8$ ).

BRASIL. II Plano Nacional de Desenvolvimento (1975-1979). Brasília, 1974. 119 p

GOVERNO DO ESTADO DO ACRE. Novo Acre. Notícias - Informações. Ano II, $\mathrm{n}^{\circ}$ 17. Rio Branco-AC: junho/julho de 1973c?

GOVERNO DO ESTADO DO ACRE. Novo Acre, O Desafio da Integração e do Desenvolvimento -Produzir no Acre, Investir no Acre, Exportar pelo Pacífico. Notícias - Informações. Ano II, n ${ }^{\circ}$ 15. Rio Branco-AC: abril de 1973b?

GOVERNO DO ESTADO DO ACRE. Novo Acre, Ano do Impacto e das Grandes Metas - "A Borracha, Fator de Ocupação do Acre, Futuro Promissor dos Investidores". Notícias - Informações Ano II, n 14. Rio Branco-AC: fevereiro de1973a?

GOVERNO DO ESTADO DO ACRE. Novo Acre, Um Estado em Ação: agora também a independência econômica do Acre. Notícias - Informações. Ano I, $n^{\circ}$ X. Rio Branco-AC: de 1 a 31 de outubro de 1972? (não paginado).

\section{- Leis e Decretos}

BRASIL. Decreto de 5 de junho, de 2012. Dispõe sobre a ampliação e os objetivos da Floresta Nacional do Araripe-Apodi, no Município de Barbalha, Estado do Ceará, criada pelo Decreto-Lei no 9.226, de 2 de maio de 1946. Brasília: 2012.

BRASIL. Lei n. 12.678, de 25 de junho de 2012. Dispõe sobre alterações nos limites dos Parques Nacionais da Amazônia, dos Campos Amazônicos e Mapinguari, das Florestas Nacionais de Itaituba I, Itaituba II e do Crepori e da Área de Proteção Ambiental do Tapajós; altera a Lei n⿳ำ 12.249, de 11 de junho de 2010; e dá outras providências. Brasília: 2012.

BRASIL. Lei n. 12.651, de 25 de maio de 2012. Dispõe sobre a proteção da vegetação nativa; altera as Leis nos 6.938, de 31 de agosto de 1981, 9.393, de 19 de dezembro de 1996, e 11.428, de 22 de dezembro de 2006; revoga as Leis nos 4.771, de 15 de setembro de 1965, e 7.754, de 14 de abril de 1989, e a Medida Provisória no 2.166-67, de 24 de agosto de 2001; e dá outras providências. Brasília, 2012.

BRASIL. Decreto de 5 de junho de 2012. Dispõe sobre a ampliação e os objetivos da Floresta Nacional do Araripe-Apodi, no Município de Barbalha, Estado do Ceará, criada pelo Decreto-lei n. 9.226, de 2 de maio de 1946. Brasília: 2012

BRASIL. Medida Provisória n. 542, de 12 de agosto de 2011. Dispõe sobre alterações nos limites do Parque Nacional Amazônia, do Parque Nacional dos Campos Amazônicos, do Parque Nacional da Mapinguari e dá outras providências. Brasília: 2011.

BRASIL. Decreto s/n. de 15 de setembro de 2008. Dá nova redação aos arts. $1^{\circ}, 2^{\circ}, 3^{\circ}$ e $4^{\circ}$ do Decreto n. 90.023, de 2 de agosto de 1984, que define os limites do Parque Nacional da Serra dos Órgãos, no Estado do Rio de Janeiro, e dá outras providências. Brasília: 2008 
BRASIL. Lei n. 11.516, de 28 de agosto de 2007. Dispõe sobre a criação do Instituto Chico Mendes de Conservação da Biodiversidade - Instituto Chico Mendes; altera as Leis $\mathrm{n}^{\mathrm{os}}$ 7.735, de 22 de fevereiro de 1989, 11.284, de 2 de março de 2006, 9.985, de 18 de julho de 2000, 10.410, de 11 de janeiro de 2002, 11.156, de 29 de julho de 2005, 11.357, de 19 de outubro de 2006, e 7.957, de 20 de dezembro de 1989; revoga dispositivos da Lei no 8.028, de 12 de abril de 1990, e da Medida Provisória no 2.216-37, de 31 de agosto de 2001; e dá outras providências. Brasília: 2007.

BRASIL. Decreto s/n., de 2 de maio de 2006. Amplia os limites da Reserva Biológica do Jaru, no Estado de Rondônia, e dá outras providências. Brasília: 2006.

BRASIL. Decreto s/n, de 13 de fevereiro de 2006. Amplia o Parque Nacional da Amazônia, no Estado do Pará, e dá outras providências. Brasília: 2006.

ACRE. Lei $\mathbf{n}^{\mathbf{0}}$ 1.426, de 27 de dezembro de 2001. Dispõe sobre a preservação e conservação das florestas do Estado, institui o Sistema Estadual de Áreas Naturais Protegidas, cria o Conselho Florestal Estadual e o Fundo Estadual de Florestas e dá outras providências. Rio Branco: 2001.

BRASIL. Lei n. 9.985, de 16de julho de 2000. Regulamenta o artigo 225, Parágrafo 1 incisos I, II, III e VII da Constituição Federal, institui o Sistema Nacional de Unidades de Conservação da Natureza e dá outras providências. Brasília: 2000.

BRASIL. Decreto s/n, de 11 de agosto de 2000. Cria a Reserva Extrativista Marinha da Baia do Iguapé, nos Municípios de Maragojipe e Cachoeira, Estado da Bahia, e dá outras providências. Brasília 2000.

BRASIL. Decreto s/n, de 14 de setembro de 2000. Dispõe sobre a criação da Área de Proteção Ambiental da Baleia Franca, no Estado de Santa Catarina, e dá outras providências. Brasília 2000.

BRASIL. Decreto s/n, de 21 de setembro de 2000. Cria o Parque Nacional da Serra da Bodoquena, no Estado de Mato Grosso do Sul, e dá outras providências. Brasília 2000.

BRASIL. Decreto s/n, de 21 de setembro de 2000. Cria a Reserva Extrativista Marinha do Corumbau nos Municípios de Porto Seguro e Prado, Estado da Bahia, e dá outras providências. Brasília 2000.

BRASIL. Decreto s/n, de 16 de novembro de 2000. Cria a Reserva Extrativista Marinha do Delta do Parnaíba, no Município de Ilha Grande de Santa Isabel, Estado do Piauí, e nos Municípios de Araióses e Água Doce, Estado do Maranhão, e dá outras providências. Brasília 2000.

BRASIL. Decreto s/n, de 8 de novembro de 2000. Cria a Reserva Extrativista do Alto Tarauacá, nos Municípios de Jordão e Tarauacá, no Estado do Acre, e dá outras providências. Brasília 2000.

BRASIL. Decreto s/n, de 20 de abril de 1999. Cria o Parque Nacional do Pau Brasil, no Município de Porto Seguro, no Estado da Bahia, e dá outras providências. Brasília 1999.

BRASIL. Decreto s/n, de 20 de abril de 1999. Cria o Parque Nacional do Descobrimento, no Município de Prado, no Estado da Bahia, e dá outras providências. Brasília 1999.

BRASIL. Decreto s/n, de 10 de junho de 1999. Autoriza a União a aceitar doação de imóveis que menciona, cria a Floresta Nacional de Brasília, e dá outras providências. Brasília 1999. 
BRASIL. Decreto s/n, de 20 de agosto de 1999. Cria a Área de Relevante Interesse Ecológico Seringal Nova Esperança, no Município de Xapuri, Estado do Acre, e dá outras providências. Brasília 1999.

BRASIL. Decreto s/n, de 21 de setembro de 1999. Cria a Floresta Nacional de Ritápolis, no Estado de Minas Gerais, e dá outras providências. Brasília 1999.

BRASIL. Decreto s/n, de 21 de setembro de 1999. Cria a Floresta Nacional Contendas do Sincorá, no Estado da Bahia, e dá outras providências. Brasília 1999.

BRASIL. Decreto s/n, de 21 de setembro de 1999. Cria o Parque Nacional Cavernas do Peruaçu, no Estado de Minas Gerais, e dá outras providências. Brasília 1999.

BRASIL. Decreto n. 3.238, de 11 de novembro de 1999. Dispõe sobre a criação da Reserva Extrativista do Lago do Cuniã, Estado de Rondônia, e dá outras providências. Brasília 1999.

BRASIL. Decreto n. 2.480, de 2 de fevereiro de 1998. Cria a Floresta Nacional do Itacaiunas, no Estado do Pará, e dá outras providências. Brasília 1998.

BRASIL. Decreto n. 2.481, de 2 de fevereiro de 1998. Cria a Floresta Nacional de Itaituba I, no Estado do Pará, e dá outras providências. Brasília 1998.

BRASIL. Decreto n. 2.482, de 2 de fevereiro de 1998. Cria a Floresta Nacional de Itaituba II, no Estado do Pará, e dá outras providências. Brasília 1998.

BRASIL. Decreto n. 2.483, de 2 de fevereiro de 1998. Cria a Floresta Nacional de Altamira, no Estado do Pará, e dá outras providências. Brasília 1998.

BRASIL. Decreto n. 2.485, de 2 de fevereiro de 1998. Cria a Floresta Nacional de Humaitá, no Estado do Amazonas, e dá outras providências. Brasília 1998.

BRASIL. Decreto n. 2.486, de 2 de fevereiro de 1998. Cria a Floresta Nacional de Carajás, no Estado do Pará, e dá outras providências. Brasília 1998.

BRASIL. Decreto s/n, de 22 de abril de 1998. Cria a Reserva Biológica União, no Estado do Rio de Janeiro, e dá outras providências. Brasília 1998.

BRASIL. Decreto s/n, de 29 de abril de 1998. Cria o Parque Nacional da Restinga de Jurubatiba, no Estado do Rio de Janeiro, e dá outras providências. Brasília 1998.

BRASIL. Decreto s/n, de 29 de abril de 1998. Cria o Parque Nacional Serra da Mocidade, no Estado de Roraima, e dá outras providências. Brasília 1998.

BRASIL. Decreto s/n, de 29 de abril de 1998. Cria o Parque Nacional do Viruá, no Estado de Roraima, e dá outras providências. Brasília 1998.

BRASIL. Decreto s/n, de 2 de outubro de 1998. Cria o Parque Nacional da Serra das Confusões, nos Municípios de Caracol, Guaribas, Santa Luz e Cristino Castro, no Estado do Piauí, e dá outras providências. Brasília 1998.

BRASIL. Decreto s/n, de 2 de outubro de 1998. Dispõe sobre a criação da Área de Proteção Ambiental dos Meandros do Rio Araguaia, nos Estados de Goiás, Mato Grosso e Tocantins, e dá outras providências. Brasília 1998.

BRASIL. Decreto s/n, de 6 de novembro de 1998. Cria a Reserva Extrativista TapajósArapiuns. Brasília 1998.

BRASIL. Decreto s/n, de 3 de janeiro de 1997. Cria a Reserva Extrativista Marinha do Arraial do Cabo. Brasília 1997. 
BRASIL. Decreto s/n, de 4 de março de 1997. Dispõe sobre a criação da Reserva Extrativista do Médio Juruá no Município de Carauarí, Estado do Amazonas, e dá outras providências. Brasília 1997.

BRASIL. Decreto s/n, de 4 de agosto de 1997. Dispõe sobre a criação da Área de Proteção Ambiental da chapada do Araripe, nos Estados do Ceará, Pernambuco e Piauí e dá outras providências. Brasília 1997.

BRASIL. Decreto s/n, de 30 de setembro de 1997. Cria o Parque Nacional de Ilha Grande, nos Estados do Paraná e Mato Grosso do Sul, e dá outras providências. Brasília 1997.

BRASIL. Decreto s/n, de 30 de setembro de 1997. Dispõe sobre a criação da Área de Proteção Ambiental das Ilhas e Várzeas do Rio Paraná, nos Estados do Paraná e Mato Grosso do Sul, e dá outras providências. Brasília 1997.

BRASIL. Decreto s/n, de 23 de outubro de 1997. Dispõe sobre a criação da Área de Proteção Ambiental da Costa dos Corais, nos Estados de Alagoas e Pernambuco, e dá outras providências. Brasília 1997.

BRASIL. Decreto n. 1.876, de 25 de abril de 1996. Altera o art. $3^{\circ}$ do Decreto ${ }^{\circ}$ 98.881, de 25 de janeiro de 1990, que dispõe sobre a Criação de Área de Proteção Ambiental no Estado de Minas Gerais. Brasília: 1996.

BRASIL. Decreto s/n, de 28 de agosto de 1996. Dispõe sobre a criação da Área de Proteção Ambiental Delta do Parnaíba, nos Estados do Piauí, Maranhão, e Ceará, e dá outras providências. Brasília 1996.

BRASIL. Decreto s/n, de 26 de novembro de 1996. Dispõe sobre a criação da Área de Proteção Ambiental Serra da Ibiapaba, nos Estados do Piauí e Ceará, e dá outras providências. Brasília 1996.

BRASIL. Decreto n. 924, de 10 de setembro de 1993. Cria a Área de Proteção Ambiental da Barra do Rio Mamanguape no Estado da Paraíba e dá outras providências. Brasília 1993.

BRASIL. Decreto n. 527, de 20 de maio de 1992. Delimita a Área de Proteção Ambiental da Região Serrana de Petrópolis, no Estado do Rio de Janeiro, criada pelo art. $6^{\circ}$ do Decreto n. 87561, de 13 de setembro de 1982, e dá outras providências. Brasília: 1992

BRASIL. Decreto n. 528, de 20 de maio de 1992. Declara como Área de Proteção Ambiental Anhatomirim, no Estado de Santa Catarina, a região que delimita e dá outras providências. Brasília: 1992.

BRASIL. Decreto n. 529, de 20 de maio de 1992. Declara como Área de Proteção Ambiental do Ibirapuitã, no Estado do Rio Grande do Sul, a região que delimita e dá outras providências. Brasília: 1992

BRASIL. Decreto n. 530, de 20 de maio de 1992. Cria a Floresta Nacional de Ipanema. Brasília: 1992.

BRASIL. Decreto n. 531, de 20 de maio de 1992. Cria, nos Estados do Rio Grande do Sul e Santa Catarina, o Parque Nacional da Serra Geral. Brasília: 1992.

BRASIL. Decreto n. 532, de 20 de maio de 1992. Cria a Reserva Extrativista da Mata Grande. Brasília: 1992. 
BRASIL. Decreto n. 533, de 20 de maio de 1992. Cria a Reserva Extrativista Marinha do Pirajubaé. Brasília: 1992.

BRASIL. Decreto n. 535, de 20 de maio de 1992. Cria a Reserva Extrativista do Extremo Norte do Estado do Tocantins. Brasília: 1992.

BRASIL. Decreto n. 536, de 20 de maio de 1992. Cria a Reserva Extrativista do Quilombo Flexal. Brasília: 1992.

BRASIL. Lei n. 6.938, de 32 de agosto de 1981. Dispõe sobre a Política Nacional do Meio Ambiente, seus fins e mecanismos de formulação e aplicação, e dá outras providências. Brasília: 1981; BRASIL. Lei n. 7.804, de 18 de julho de 1989. Altera a Lei $\mathrm{n}^{\mathrm{o}}$ 6.938, de 31 de agosto de 1981, que dispõe sobre a Política Nacional do Meio Ambiente, seus fins e mecanismos de formulação e aplicação, a Lei $n^{0} 7.735$, de 22 de fevereiro de 1989, a Lei $\mathrm{n}^{\circ} 6.803$, de 2 de julho de 1980, e dá outras providências. Brasília: 1989; BRASIL. Lei n. 8.028, de 12 de abril de 1990. Dispõe sobre a organização da Presidência da República e dos Ministérios, e dá outras providências. Brasília: 1990.

BRASIL. Decreto n. 98.897, de 30 de janeiro de 1990. Dispõe sobre as reservas extrativistas e dá outras providências. Brasília: 1990.

BRASIL. Decreto n. 99.143, de 12 de março de 1990. Declara de preservação permanente a vegetação natural das áreas que descreve. Brasília: 1990.

BRASIL. Decreto n. 98.845, de 17 de Janeiro de 1990. Cria, no Estado do Espírito Santo, a FLORESTA NACIONAL DO RIO PRETO. Brasília: 1990.

BRASIL. Decreto n. 98.863, de 23 de Janeiro de 1990. Cria a Reserva Extrativista do Alto Juruá. Brasília: 1990.

BRASIL. Decreto n. 9 8.864, de 23 de Janeiro de 1990. Cria a Estação Ecológica de Tamoios, e dá outras providências. Brasília: 1990.

BRASIL. Decreto n. 98.881, de 25 de Janeiro de 1990. Dispõe sobre a criação de área de proteção ambiental no Estado de Minas Gerais. e dá outras providências. Brasília: 1990.

BRASIL. Decreto n. 98.884, de 25 de Janeiro de 1990. Cria a Unidade de Conservação denominada RESERVA BIOLÓGICA GUARIBAS, no Estado da Paraíba, e dá outras providências. Brasília: 1990.

BRASIL. Decreto n. 98.891, de 26 de janeiro de 1990. Dispõe sobre e criação da Área de Proteção Ambiental no Estado de Minas Gerais, e dá outras providências. Brasília: 1990.

BRASIL. Decreto n. 99.142, de 12 de março de 1990. Cria, no Estado de Santa Catarina, a Reserva Biológica Marinha do Arvoredo, e dá outras providências. Brasília: 1990.

BRASIL. Decreto n. 99.144, de 12 de março de 1990. Cria a Reserva Extrativista Chico Mendes. Brasília: 1990.

BRASIL. Decreto n. 99.145, de 12 de março de 1990. Cria a Reserva Extrativista do Rio Cajari. Brasília: 1990.

BRASIL. Decreto n. 99.166, de 13 de março de 1990. Cria a Reserva Extrativista do Rio Ouro Preto. Brasília: 1990. 
BRASIL. Decreto n. 99.275, de 6 de junho de 1990. Dispõe sobre a criação da Árie Área de Relevante Interesse Ecológico Cerrado Pé-de-Gigante, no Município de Santa Rita do Passa-Quatro, Estado de São Paulo. Brasília: 1990.

BRASIL. Decreto n. 99.276, de 6 de Junho de 1990. Dispõe sobre a criação da ArieÁrea de Relevante Interesse Ecológico Buriti de Vassununga, na Área Florestal de Vassununga, no Município de Santa Rita do Passa-Quatro, Estado de São Paulo. Brasília: 1990.

BRASIL. Decreto n. 99.277, de 6 de Junho de 1990. Cria, no Estado do Amazonas, a Reserva Biológica do Uatumã e dá outras providências. Brasília: 1990.

BRASIL. Decreto n. 99.278, de 6 de junho de 1990. Dispõe sobre a criação da Área de Proteção Ambiental (APA) nos Estados do Maranhão e Tocantins, e dá outras providências. Brasília: 1990.

BRASIL. Decreto n. 98.897, de 30 de janeiro de 1990. Dispõe sobre as Reservas Extrativistas e dá outras providências.

BRASIL. Decreto no 98.863, de 23 de janeiro de 1990. Cria a Reserva Extrativista do Alto Juruá. Brasília: 1990.

BRASIL. Decreto n 97.839, de 16 de junho de 1989. Cria o Parque Nacional da Serra do Divisor. Brasília: 1989.

BRASIL. Lei n. 7.745, de 22 de fevereiro de 1989. Dispõe sobre a extinção de órgão e de entidade autárquica, cria o Instituto Brasileiro do Meio Ambiente e dos Recursos Naturais Renováveis e dá outras providências. Brasília: Senado Federal, 1989.

BRASIL. Lei n. 7.797, de 10 de julho de 1989. Cria o Fundo Nacional de Meio Ambiente e dá outras providências. Brasília: 1989.

BRASIL. Lei n. 7.804, de 18 de julho de 1989. Altera a Lei $n^{\circ}$ 6.938, de 31 de agosto de 1981, que dispõe sobre a Política Nacional do Meio Ambiente, seus fins e mecanismos de formulação e aplicação, a Lei no 7.735 , de 22 de fevereiro de 1989, a Lei $n^{\circ} 6.803$, de 2 de julho de 1980, e dá outras providências. Brasília: 1989.

BRASIL. Lei n. 7.804, de 18 de julho de 1989. Altera a Lei no 6.938, de 31 de agosto de 1981, que dispõe sobre a Política Nacional do Meio Ambiente, seus fins e mecanismos de formulação e aplicação, a Lei no 7.735 , de 22 de fevereiro de 1989, a Lei nº 6.803, de 2 de julho de 1980, e dá outras providências. Brasília: 1989.

BRASIL. Decreto n. 98.051, de 14 de agosto de 1989. Cria a Floresta Nacional Mapiá INAUINI. Brasília: 1989.

BRASIL. Decreto n. 97.545, de $1^{\circ}$ de março de 1989. Cria, no Estado de Roraima, a Floresta Nacional de Roraima, com os limites que específica e dá outras providências. Brasília: 1989

BRASIL. Decreto n. 97.546, de $1^{\circ}$ de março de 1989. Cria, no Estado do Amazonas, a Floresta Nacional do Amazonas, com os limites que especifica e dá outras providencias. Brasília: 1989.

BRASIL. Decreto n. 97.629, de 10 de abril de 1989. Cria, no Estado do Amazonas, a Floresta Nacional de Tefé, com os limitantes que especifica, e dá outras providências. Brasília: 1989. 
BRASIL. Decreto n. 97.630, de 10 de abril de 1989. Cria, no Estado do Amapá, a Floresta Nacional do Amapá, com limites que especifica, e dá outras providências. Brasília: 1989.

BRASIL. Decreto n. 97.656, de 12 de abril de 1989. Cria, no Estado de Mato Grosso, o Parque Nacional da Chapada dos Guimarães, e dá outras providências. Brasília: 1989.

BRASIL. Decreto n. 97.657, de 12 de abril de 1989. Cria a Reserva Biológica do Córrego Grande. Brasília: 1989.

BRASIL. Decreto n. 97.658, de 12 de abril de 1989. Cria nos Estados da Bahia e de Minas Gerais, o Parque Nacional Grande Sertão Veredas, com limites que especifica e dá outras providências. Brasília: 1989.

BRASIL. Decreto n. 97.688, de 25 de abril de 1989. Cria, no Estado do Paraná, o Parque Nacional do Superagui, e dá outras providências. Brasília: 1989.

BRASIL. Decreto n. 97.718, de 5 de maio de 1989. Dispõe sobre a criação da Área de Proteção Ambiental do Igarapé Gelado, no Estado do Pará. Brasília: 1989.

BRASIL. Decreto n. 97.719, de 5 de Maio de 1989. Cria a Reserva Biológica do Tapirapé. Brasília: 1989.

BRASIL. Decreto n. 97.720, de 5 de maio de 1989. Cria a Floresta Nacional do Tapirapé-Aquiri. Brasília: 1989.

BRASIL. Decreto n. 97.780, de 23 de maio de 1989. Cria a Reserva Biológica do Tinguá, e dá outras providências. Brasília: 1989.

BRASIL. Decreto n. 97.839, de 16 de junho de 1989. Cria o Parque Nacional da Serra do Divisor. Brasília: 1989.

BRASIL. Decreto n. 97.887, de 28 de Junho de 1989. Cria o Parque Nacional do Monte Roraima e dá outras providências. Brasília: 1989.

BRASIL. Decreto n. 98.182, de 26 de setembro de 1989. Dispõe sobre a criação de área de proteção ambiental no Estado de Minas Gerais, e dá outras providências. Brasília: 1989.

BRASIL. Decreto n. 98.524, de 13 de dezembro de 1989. Cria a reserva Biológica de Pedra Talhada. Brasília: 1989.

BRASIL. Decreto n. 98.704, de 27 de Dezembro de 1989. Cria a Floresta Nacional de Saracá - Taquera. Brasília: 1989.

BRASIL. Constituição (1988). Constituição da República Federativa do Brasil. Brasília, DF: Senado Federal, 1988.

BRASIL. Decreto n 96.189, de 21 de junho de 1988. Cria, no Estado do Acre, a Floresta Nacional do Macauã, com limites que especifica, e dá outras providências. Brasília: 1988.

BRASIL. Decreto n. 95.614, de 12 de Janeiro de 1988. Cria a Reserva Biológica do Gurupi e dá outras providências. Brasília: 1988.

BRASIL. Decreto n. 95.818, de 11 de Março de 1988. Cria a Floresta Nacional de Ibirama, no Estado de Santa Catarina, e dá outras providências. Brasília: 1988.

BRASIL. Decreto n. 96.188, de 21 de Junho de 1988. Cria, no Estado de Rondônia, a Floresta Nacional do Bom Futuro, com limites que especifica, e dá outras providências. Brasília: 1988. 
BRASIL. Decreto n. 96.189, de 21 de Junho de 1988. Cria, no Estado do Acre, a Floresta Nacional do Macauã, com limites que especifica, e dá outras providências. Brasília: 1988.

BRASIL. Decreto n. 96.190, de 21 de Junho de 1988. Cria, no Estado do Amazonas, a Floresta Nacional do Purus, com limites que especifica, e dá outras providências. Brasília: 1988.

BRASIL. Decreto n. 96.693, de 14 de Setembro de 1988. Cria o Parque Nacional Marinho de Fernando de Noronha e dá outras providências. Brasília: 1988.

BRASIL. Decreto n. 96.999, de 20 de Outubro de 1988. Cria, no litoral do Estado de Sergipe, a Reserva Biológica de Santa Isabel e dá outras providências. Brasília: 1988.

BRASIL. Resolução Conama n. 12, de 14 de dezembro de 1988. Rio de Janeiro: 1988.

BRASIL. Decreto n. 94.656, de 20 de Julho de 1987. Cria as Estações Ecológicas de Carijós, Pirapitinga e Tupinambás, e dá outras providências. Brasília: 1987.

BRASIL. Decreto n. 93.053, de 31 de julho de 1986. Acresce área aos limites da Estação Ecológica de Guaraqueçaba, no Estado do Paraná, criada pelo Decreto ${ }^{\circ}$ 87.222, de 31 de maio de 1982, e dá outras providências. Brasília: 1986.

BRASIL. Decreto n. 92.753, de 5 de junho de 1986. Denomina Augusto Ruschi a Reserva Biológica de Nova Lombardia, no Município de Santa Tereza, Estado do Espírito Santo. Brasília: 1986

BRASIL. Decreto n. 97.755, de 5 de junho de 1986. Declara Área de Proteção Ambiental o Território Federal de Fernando de Noronha, o Atol das Rocas e os Penedos de São Pedro e São Paulo, e dá outras providências. Brasília: 1986.

BRASIL. Decreto n. 92.964, de 21 de julho de 1986. Cria a Estação Ecológica dos Tupiniquins em ilhas e laje oceânicas que indica, e dá outras providências. Brasília: 1986.

BRASIL. Decreto n. 93.369, de 8de outubro de 1986. Cria a Floresta Nacional Mário Xavier, no Estado do Rio de Janeiro, e dá outras providências. Brasília: 1986.

BRASIL. Decreto n. 93.546, de 6 de Novembro de 1986. Cria o Parque Nacional da Lagoa do Peixe. Brasília: 1986.

BRASIL. Decreto n. 91.145, de 15 de março de 1985. Cria o Ministério do Desenvolvimento Urbano e Meio Ambiente, dispõe sobre sua estrutura, transferindo-lhe os órgãos que menciona, e dá outras providências. Brasília: 1985.

BRASIL. Decreto n. 90.823, de 18 de janeiro de 1985. Altera os limites do Parque Nacional da Amazônia, criado pelo Decreto nº 73.683, de 19 de fevereiro de 1974. Brasília: 1985

BRASIL. Decreto n. 91.884, de 5 de novembro de 1985. Declara como Área de Relevante Interesse Ecológico - ARIE as porções de terras de vários ecossistemas que integram o Projeto Dinâmica Biológica de Fragmentos Florestais, localizada no Estado do Amazonas, e dá outras providências. Brasília: 1985.

BRASIL. Decreto n. 90.791, de 9 de janeiro de 1985. Dispõe sobre a declaração de área de relevante interesse ecológico, no Município de Cosmópolis, no Estado de São Paulo, e dá outras providências. Brasília: 1985 
BRASIL. Decreto n. 90.883, de 31 de janeiro de 1985. Dispõe sobre a implantação da Área de Proteção Ambiental de Guaraqueçaba, no Estado do Paraná, e dá outras providências. Brasília: 1985.

BRASIL. Decreto n. 91.303, de 3 de junho de 1985. Dispõe sobre a declaração de área de relevante interesse ecológico, em Brasília, Distrito Federal, e dá outras providências. Brasília: 1985.

BRASIL. Decreto n. 91.304, de 3 de Junho de 1985. Dispõe sobre implantação de área de proteção ambiental nos estados de Minas Gerais, Rio de Janeiro e São Paulo, e dá outras providências. Brasília: 1985.

BRASIL. Decreto n. 91.306, de 3 de Junho de 1985. Cria a Estação Ecológica Niquiá em área de terra que indica, e dá outras providências. Brasília: 1985.

BRASIL. Decreto n. 91.307, de 3 de Junho de 1985. Cria a Estação Ecológica JuamiJapurá, em área de terra que indica, e dá outras providências. Brasília: 1985.

BRASIL. Decreto n. 91.655, de 17 de setembro de 1985. Cria o Parque Nacional da Chapada da Diamantina. Brasília: 1985.

BRASIL. Decreto n. 91.885, de 5 de novembro de 1985. Declara como Área de Relevante Interesse Ecológico - ARIE a Mata de Santa Genebra, no Estado de São Paulo, e dá outras providências. Brasília: 1985.

BRASIL. Decreto n. 91.886, de 5 de novembro de 1985. Declara como Área de Relevante Interesse Ecológico - ARIE, uma área denominada Javarí-Buriti, no Estado do Amazonas, e dá outras Providências. Brasília: 1985.

BRASIL. Decreto n. 91.887, de 5 de novembro de 1985. Declara como Área de Relevante Interesse Ecológico - ARIE as Ilhas de Queimada Pequena e Queimada Grande, no litoral de São Paulo, e dá outras providências. Brasília: 1985.

BRASIL. Decreto n. 91.889, de 5 de novembro de 1985. Declara como Área de Relevante Interesse Ecológico - ARIE a Ilha denominada Ameixal, situada no Rio Una, no Estado de São Paulo, e dá outras providências. Brasília: 1985.

BRASIL. Decreto n. 91.890, de 5 de novembro de 1985. Declara como Área de Relevante Interesse Ecológico - ARIE, uma área de mangues denominada Manguezais da Foz do Rio Mamanguape, no Estado da Paraíba, e dá outras providências. Brasília: 1985.

BRASIL. Decreto n. 90.023, de 2 de agosto de 1984. Define os limites do Parque Nacional da Serra dos Órgãos, criado pelo Decreto-lei n. 1.822, de 30 de novembro de 1939 e dá outras providências. Brasília: 1984.

43BRASIL. Decreto n. 89.569, de 23 de abril de 1984. Altera os limites da Reserva Biológica do Córrego do Veado, criada pelo Decreto $n^{\circ} 87590$, de 20 de setembro de 1982. Brasília: 1984.

BRASIL. Decreto n. 90.223, de 25 de setembro de 1984. Cria, no Estado de Minas Gerais, o Parque Nacional da Serra do Cipó e dá outras providências. Brasília: 1984.

BRASIL. Decreto n. 90.224, de 25 de setembro de 1984. Cria a FLORESTA NACIONAL DO JAMARI, no Estado de Rondônia, e dá outras providências. Brasília: 1984. 
BRASIL. Decreto n. 90.225, de 25 de setembro de 1984. Dispõe sobre a implantação da Área de Proteção Ambiental de Guapi-Mirim, no Estado do Rio de Janeiro, e dá outras providências. Brasília: 1984.

BRASIL. Decreto n. 90.222, de 25 de setembro de 1984. Cria, no Estado do Espírito Santo, a Reserva Biológica de Comboios, e dá outras providências. Brasília: 1984.

BRASIL. Decreto n. 90.347, de 23 de outubro de 1984. Dispõe sobre a implantação de área de proteção ambiental nos Municípios de Cananéia, Iguape, e Peruíbe, no Estado de São Paulo, e dá outras Providências. Brasília: 1984.

BRASIL. Decreto n. 88.351, de $1^{\circ}$ de junho de 1983. Regulamenta a Lei ${ }^{\circ}$ 6.938, de 31 de agosto de 1981, e a Lei ${ }^{\circ}$ 6.902, de 27 de abril de 1981, que dispõem, respectivamente, sobre a Política Nacional do Meio Ambiente e sobre a criação de Estações Ecológicas e Áreas de Proteção Ambiental, e dá outras providências. Brasília: 1983.

BRASIL. Decreto n. 88.218, de 6 de abril de 1983. Cria o Parque Nacional Marinho dos Abrolhos. Brasília: 1983.

BRASIL. Decreto n. 88.421, de 21 de junho de 1983. Dispõe sobre a implantação da Área de proteção Ambiental de Piaçabuçu, no Estado de Alagoas e dá outras providências. Brasília: 1983

BRASIL. Decreto n. 88.541, de 21 de julho de 1983. Cria a Reserva Ecológica de JutaíSolimões, em área de terra que indica e dá outras providências. Brasília: 1983.

BRASIL. Decreto n. 88.744, de 21 de setembro de 1983. Cria, no Estado de Pernambuco, a Reserva Biológica de Saltinho e dá outras providências. Brasília: 1983.

BRASIL. Decreto n. 88.940, de 7 de novembro de 1983. Dispões sobre a criação das Áreas de Proteção Ambiental das Bacias dos Rios São Bartolomeu e Descoberto, e dá outras providências. Brasília: 1983.

BRASIL. Decreto n. 89.242, de 27 de dezembro de 1983. Dispõe sobre a criação da Área de Proteção Ambiental de Cairuçu, no Estado do Rio de Janeiro e dá outras providências. Brasília: 1983.

BRASIL. Decreto n. 87.586, de 20 de setembro de 1982. Amplia a área do Parque Nacional de Itatiaia, criado pelo Decreto n. 1.713, de 14 de janeiro de 1937 e dá outras providências. Brasília: 1982

BRASIL. Decreto n. 86.097, de 12 de abril de 1981. Cria a Estação Ecológica do Jari, e dá outras providências. Brasília: 1982.

BRASIL. Decreto n. 89.440, de 13 de março de 1984. Altera o artigo $1^{\circ}$ do Decreto ${ }^{\circ}$ 87.092, de 12 de abril de 1982, que cria a Estação Ecológica do Jari. Brasília: 1982.

BRASIL. Decreto n. 87.222, de 31 de Maio de 1982. Cria as Estações Ecológicas do Seridó, Serra das Araras, Guaraqueçaba, Caracaraí e dá outras providências. Brasília: 1982

BRASIL. Decreto n. 87.588, de 20 de setembro de 1982. Cria, no Estado do Espírito Santo, a Reserva Biológica de Sooretama, com os limites que específica e dá outras providências. Brasília: 1982

BRASIL. Decreto n. 87.561, de 13 de setembro de 1982. Dispõe sobre as medidas de recuperação e proteção ambiental da Bacia Hidrográfica do Rio Paraíba do Sul e dá outras providências. Brasília: 1982 
BRASIL. Decreto n. 87.561, de 13 de Setembro de 1982. Dispõe sobre as medidas de recuperação e proteção ambiental da Bacia Hidrográfica do Rio Paraíba do Sul e dá outras providências. Brasília: 1982.

BRASIL. Decreto n. 87.590, de 20 de setembro de 1982. Cria, no Estado do Espírito Santo, a Reserva Biológica do Córrego do Veado. Brasília: 1982.

BRASIL. Decreto n. 87.585, de 20 de Setembro de 1982. Cria, no Estado do Amazonas, a Reserva Biológica do Abufari. Brasília: 1982.

BRASIL. Decreto n. 87.589, de 20 de setembro de 1982. Cria, no Estado do Espírito Santo, a Reserva Biológica de Nova Lombardia. Brasília: 1982.

BRASIL. Decreto n. 87.587, de 20 de Setembro de 1982. Cria, no Estado de Rondônia, a Reserva Biológica do Guaporé. Brasília: 1982

BRASIL. Decreto n. 87.591, de 20 de Setembro de 1982. Cria, no Estado de Pernambuco, a Reserva Biológica de Serra Negra. Brasília: 1982.

BRASIL. Decreto n. 86.061, de 2 de junho de 1981. Cria Estações Ecológicas e dá outras providencias. Brasília: 1981

BRASIL. Decreto n. 86.676, de $1^{\circ}$ de dezembro de 1981. Fixa novos limites do Parque Nacional do Iguaçu no Estado do Paraná. Brasília: 1981.

BRASIL. Lei n. 6.902, de 27 de abril de 1981. Dispõe sobre a criação de estações ecológicas, áreas de proteção ambiental e dá outras providências Brasília: 1981.

BRASIL. Lei n. 6.938, de 32 de agosto de 1981. Dispõe sobre a Política Nacional do Meio Ambiente, seus fins e mecanismos de formulação e aplicação, e dá outras providências. Brasília: 1981.

BRASIL. Lei $\mathbf{n}^{\mathbf{0}}$ 6.902, de 27 de abril de 1981. Dispõe sobre a criação de Estações Ecológicas, Áreas de Proteção Ambiental e dá outras providências. Brasília: 1981

BRASIL. Decreto n. 86.060, de 02 de junho de 1981. Cria, no Estado do Maranhão, o Parque Nacional dos Lençóis Maranhenses, com os limites que especifica e dá outras providências. Brasília: 1981.

BRASIL. Decreto n. 86.392, de 24 de setembro de 1981. Cria no Estado de Mato Grosso, o Parque Nacional do Pantanal Mato-Grossense. Brasília: 1981.

BRASIL. Decreto n 86.061, de 2 de junho de 1981. Cria Estações Ecológicas, e dá outras providências. Brasília: 1981. (Este foi um Decreto único que criou as primeiras oito Estações Ecológicas no país. Além da Estação Ecológica Rio Acre mais três unidades foram criadas no bioma amazônico, a Estação Ecológica de Anavilhanas no Amazonas, a Estação Ecológica de Maracá - Jipioca no Amapá e a Estação Ecológica de Maracá em Roraima; duas no Cerrado, a Estação Ecológica Uruçuí-Una e a Estação Ecológica de Iquê; uma na Mata Atlântica, a Estação Ecológica Aracuri- Esmeralda;e uma no Pantanal, a Estação Ecológica do Taiamã).

BRASIL. Decreto n. 84.844, de 24 de junho de 1980. Altera os limites do Parque Nacional do Araguaia e do Parque Indígena do Araguaia. Brasília: 1980.

BRASIL. Decreto n. 84.913, de 15 de julho de 1980. Cria, no Território Federal do Amapá, o Parque Nacional do Cabo Orange, com os limites que especifica e dá outras providências. Brasília: 1980. 
BRASIL. Decreto n. 84.914, de 16 de julho de 1980. Cria, no Território Federal do Amapá, a Reserva Biológica do Lago Piratuba, com os limites que especifica e dá outras providências. Brasília: 1980.

BRASIL. Decreto n. 85.200, de 24 de setembro de 1980. Cria, no Estado do Amazonas, o Parque Nacional do Jaú. Brasília: 1980.

BRASIL. Decreto n. 85.463, de 10 de dezembro de 1980. Cria, no Estado da Bahia, no Município de UMA, a Reserva Biológica de UNA, com os limites que especifica e dá outras providências. Brasília: 1980.

BRASIL. Decreto n. 83.548, de 5 de junho de 1979. Cria no Estado do Piauí, o Parque Nacional da Serra da Capivara, com os limites que específica e da outras providência. Brasília: 1979.

BRASIL. Decreto n. 83.549, de 5 de junho de 1979. Cria a Reserva Bilógica do Atol das Rocas e dá outras providências. Brasília: 1979.

BRASIL. Decreto n. 83.550, de 5 de junho de 1979. Cria, no Estado do Amazonas, o Parque Nacional do Pico da Neblina, com os limites que especifica e dá outras providências. Brasília: 1979.

BRASIL. Decreto n. 83.716, de 11 de julho de 1979. Cria, no território Federal e Rondônia, a Reserva Biológica do Jaru, com os limites que especifica, e dá outras providências. Brasília: 1979.

BRASIL. Decreto n. 84.018, de 21 de setembro de 1979. Cria a Reserva Biológica do rio Trombetas e dá outras providências. Brasília: 1979.

BRASIL. Decreto n. 84.019, de 21 de setembro de 1979. Cria, no Território Federal de Rondônia, o Parque Nacional de Pacaás Novos, com limites que especifica, e dá outras providências. Brasília: 1979.

BRASIL. Decreto no 84.017, de 21 de setembro de 1979. Aprova o Regulamento dos Parques Nacionais Brasileiros. Brasília: 1979.

BRASIL. Decreto $\mathbf{n}^{\mathbf{0}}$ 79.048, de 27 de dezembro de 1976. Declara de interesse social, para fins de desapropriação, imóveis rurais situados no Município de Sena Madureira, Estado do Acre, compreendidos na área prioritária de Reforma Agrária, assim declarada pelo Decreto $\mathrm{n}^{\circ}$ 67.557, de 12 de novembro de 1970, e ampliada pelo Decreto $\mathrm{n}^{\circ} 75.295$, de 27 de janeiro de 1975. Brasília: 1976.

BRASIL. Decreto no 79.049, de 27 de dezembro de 1976. Declara de interesse social, para fins de desapropriação, imóveis rurais situados no Município de Rio Branco, Estado do Acre, compreendidos na área prioritária de Reforma Agrária, assim declarada pelo Decreto $\mathrm{n}^{\circ}$ 67.557, de 12 de novembro de 1970, e ampliada pelo Decreto $\mathrm{n}^{\circ} 75.295$, de 27 de janeiro de 1975. Brasília: 1976.

BRASIL. Decreto n. 76.534, de 3 de novembro de 1975. Dá nova delimitação à área definida pelo artigo $3^{\circ}$ do Decreto número 73.791, de 11 de março de 1974, que cria a Reserva Biológica Nacional de Poço das Antas, no Estado do Rio de Janeiro. Brasília: 1975

ACRE. Lei n. 560, de 10 de julho de 1975. "Autoriza a constituição da Companhia do Desenvolvimento Agrário e Colonização do Acre - COLONACRE. Rio Branco: 1975. 
ACRE. Lei n. 564, de 26 de setembro de 1975. "Autoriza a constituição da Companhia de Armazéns Gerais e Entrepostos do Estado do Acre - CAGEACRE. Rio Branco: 1975.

BRASIL. Decreto n. 73.684, de 19 de Fevereiro de 1974. Cria a Floresta Nacional do Tapajós, e dá outras providências. Brasília: 1974.

BRASIL. Decreto n. 73.791, de 11 de março de 1974. Cria a Reserva Biológica Nacional de Poço das Antas, no Estado do Rio de Janeiro, com limites que especifica e dá outras providências. Brasília: 1974.

BRASIL. Decreto n. 74.607, de 25 de setembro de 1974. Dispõe sobre a criação do Programa de Pólos Agropecuários e Agrominerais da Amazônia (POLAMAZÔNIA). Brasília: 1974.

BRASIL. Lei n. 6.151, de 4 de dezembro de 1974. Dispõe sobre o Segundo Plano Nacional de Desenvolvimento (PND), para o período de 1975 a 1979. Brasília: 1974.

BRASIL. Decreto $\mathbf{n}^{\mathbf{0}} \mathbf{7 0 . 6 7 7}$, de 6 de junho de 1972. Dispõe sobre a execução do Decreto-lei no 1.971, que institui o PROTERRA. Brasília, 1972.

BRASIL. Decreto n. 73.683, de 19 de fevereiro de 1974. Cria o Parque Nacional da Amazônia e dá outras providências. Brasília: 1974.

BRASIL. Decreto n. 73.684, de 19 de fevereiro de 1974. Cria a Floresta Nacional do Tapajós, e dá outras providências. Brasília; 1974.

BRASIL. Decreto n. 73.791, de 11 de março de 1974. Brasília: 1074.Cria a Reserva Biológica Nacional de Poço das Antas, no Estado do Rio de Janeiro, com os limites que especifica e dá outras providências. Brasília: 1974.

BRASIL. Decreto n. 73.030, de 30 de outubro de 1973. Cria, no âmbito do Ministério do Interior, a Secretaria Especial do Meio Ambiente - SEMA, e dá outras providências. Brasília: 1973.

BRASIL. Decreto n. 70.694, de 8 de junho de 1972. Altera artigo $1^{\circ}$, do Decreto número 68.171, de 4 de fevereiro de 1971, que cria o Parque Nacional da Serra da Bocaina, e dá outras providências. Brasília: 1972.

BRASIL. Decreto no 70.677, de 6 de junho de 1972. Dispõe sobre a execução do Decreto-lei nº 1.971, que institui o PROTERRA. Brasília, 1972.

BRASIL. Decreto-Lei n. 3.124, de 19 de março de 1941. Cria o Instituto Nacional do Pinho e dá outras providências. Rio de Janeiro: 8 de outubro de 1942.

BRASIL. Decreto-Lei no 1.232, de 17 de julho de 1972. Institui Programa de Incentivo à Produção de Borracha Vegetal. Brasília: 1972.

BRASIL. Decreto n. 70.492, de 11 de maio de 1972. Dá nova denominação ao Parque Nacional do Tocantins; altera dispositivos do Decreto $n^{\circ} 49.875$, de 11 de janeiro de 1961, e dá outras providências. Brasília: 1972.

BRASIL. Decreto n. 70.375, de 06 de abril de 1972. Dispõe sobre o Parque Nacional das Emas. Brasília: 1972.

BRASIL. Decreto n. 70.186, de 23 de fevereiro de 1972. Dispõe sobre a administração das áreas integrantes do Parque Nacional da Tijuca. Brasília: 1972.

BRASIL. Decreto n. 70.355, de 03 de abril de 1972. Cria o Parque Nacional da Serra da Canastra, no Estado de Minas Gerais, com os limites que especifica, e dá outras providências. Brasília: 1972. 
BRASIL. Decreto n. 68.172, de 4 de fevereiro de 1971. Cria o Parque Nacional da Serra da Bocaina e dá outras providências. Brasília: 1971.

BRASIL. Decreto-Lei n. 1.179, de 6 de junho de 1971. Institui o Programa de Redistribuição de Terras e de Estímulo à Agro-indústria do Norte e do Nordeste (PROTERRA), altera a legislação do imposto de renda relativa a incentivos fiscais e dá outras providências. Brasília: 1971.

BRASIL. Lei n. 5.727, de 4 de novembro de 1971. Dispõe sobre o Primeiro Plano Nacional de Desenvolvimento (PND), para o período de 1972 a 1974. Brasília: 1971.

BRASIL. Decreto-Lei no 1.179, de 6 de julho de 1971. Institui o Programa de Redistribuição de Terras e de Estímulo à Agro-indústria do Norte e do Nordeste (PROTERRA), altera a legislação do imposto de renda relativa a incentivos fiscais e dá outras providências. Brasília, 1971.

BRASIL. Decreto no 68.17,2 de 04 de fevereiro de 1971. Cria o Parque Nacional da Serra da Bocaina e dá outras providências. Brasília: 1971.

BRASIL. Decreto-Lei n. 1.106, de 16 de junho de 1970. Cria o Programa de Integração Nacional, altera a legislação do imposto de renda das pessoas jurídicas na parte referente a incentivos fiscais e dá outras providências. Brasília: 1970.

BRASIL. Decreto-Lei no 1.110, de 09 de julho de 1970. Cria o Instituto Nacional de Colonização e Reforma Agrária (INCRA), extingue o Instituto Brasileiro de Reforma Agrária, o Instituto Nacional de Desenvolvimento Agrário e o Grupo Executivo da Reforma Agrária e dá outras providências. Brasília: 1970.

BRASIL. Decreto-Lei no 1.106, de 16 de junho de 1970. Cria o Programa de Integração Nacional, altera a legislação do imposto de renda das pessoas jurídicas na parte referente a incentivos fiscais e dá outras providências. Brasília, 1970.

BRASIL. Decreto-Lei n. 605, de 2 de julho de 1969. Extingue o Parque Nacional de Paulo Afonso e dá outras providências. Brasília: 1969.

BRASIL. Decreto no 60.079, de 16 de janeiro de 1967. Aprova o "Regulamento Geral do Plano de Valorização Econômica da Amazônia”. Brasília: 1967.

BRASIL. Decreto-Lei n. 289, de 28 de fevereiro de 1967. Cria o Instituto Brasileiro do Desenvolvimento Florestal e dá outras providências. Brasília: 1967.

BRASIL. Decreto-Lei no 288, de 28 de fevereiro de 1967. Altera as disposições da Lei número 3.173 de 6 de junho de 1957 e regula a Zona Franca de Manaus. Brasília, 1967.

BRASIL. Decreto-Lei no 291, de 28 de fevereiro de 1967. Estabelece incentivos para o desenvolvimento da Amazônia Ocidental da Faixa de Fronteiras abrangida pela Amazônia e dá outras providências. Brasília: 1967.

BRASIL. Lei n. ${ }^{\circ}$ 5.197, de 3 de janeiro de 1967. Dispõe sobre a proteção à fauna e dá outras providências. Brasília: 1967.

BRASIL. Decreto no 60.079, de 16 de janeiro de 1967. Aprova o "Regulamento Geral do Plano de Valorização Econômica da Amazônia”. Brasília: 1967.

BRASIL. Decreto-Lei no 288, de 28 de fevereiro de 1967. Altera as disposições da Lei número 3.173 de 6 de junho de 1957 e regula a Zona Franca de Manaus. Brasília, 1967. 
BRASIL. Decreto n. 60.183, de 28 de fevereiro de 1967. Altera o nome do Parque Nacional do Rio de Janeiro, criado pelo Decreto n ${ }^{\circ} 50.923$, de 6 de julho de 1961, para Parque Nacional da Tijuca, (PNT), com as dimensões e demais características previstas no presente Decreto, e dá outras providências. Brasília: 1967.

BRASIL. Lei n. 5.173, de 27 de outubro de 1966. Dispõe sobre o Plano de Valorização Econômica da Amazônia; extingue a Superintendência do Plano de Valorização Econômica da Amazônia (SPVEA), cria a Superintendência do Desenvolvimento da Amazônia (SUDAM), e dá outras providências. Brasília: 1966.

BRASIL. Lei $\mathbf{n}^{\circ}$ 5.122, de 28 de setembro de 1966. Dispõe sobre a transformação do Banco de Crédito da Amazônia em Banco da Amazônia S.A. Brasília: 1966.

BRASIL. Lei no 5.174, de 27 de outubro de 1966. Dispõe sobre a concessão de incentivos fiscais em favor da Região Amazônica e dá outras providências. Brasília: 1966.

BRASIL. Lei n. ${ }^{\circ}$ 4771, de 15 de setembro de 1965. Institui o novo Código Florestal. Brasília: 1965.

BRASIL. Lei $\mathbf{n}^{\mathbf{0}} \mathbf{4 5 0 4}$, de 30 de novembro de 1964. Dispõe sobre o Estatuto da Terra, e dá outras providências. Brasilia, 1964.

BRASIL. Lei no 4.216 de 6 de maio de 1963. Estende à região amazônica os benefícios do art. 34 da Lei n ${ }^{\circ} 3.995$, de 14 de dezembro de 1961 (Plano Diretor da SUDENE). Brasília, 1963.

BRASIL. Decreto n. 49.875, de 11 de janeiro de 1961 Cria o "Parque Nacional do Tocantins", no Estado de Goiás e dá outras providências. Brasília: 1961.

BRASIL. Decreto n. 49.874, de 11 de janeiro de 1961. Cria o "Parque Nacional das Emas", no Estado de Goiás, abrangendo parte menor, do Estado de Mato Grosso. Brasília: 1961.

BRASIL. Decreto n. 50.646, de 24 de maio de 1961. Cria o Parque Nacional de Caparaó e dá outras providências. Brasília: 1961.

BRASIL. Decreto n. 50.744, de 8 de junho de 1961 Cria o Parque Nacional de Sete Cidades, integrante da Seção de Parques e Florestas Nacionais do

Serviço Florestal, do Ministério da Agricultura. Brasília: 1961.

BRASIL. Decreto n. 50.923, de 06 de julho de 1961. Cria o Parque Nacional do Rio de Janeiro, no Estado do Rio da Guanabara. Brasília: 1961.

BRASIL. Decreto n. 50.922, de 06 de julho de 1961. Parna de São Joaquim Cria o Parque Nacional de São Joaquim (P.N.S.J.), no Estado de Santa Catarina, e dá outras providências. Brasília: 1961.

BRASIL. Decreto n. 239, de 28 de novembro de 1961. Cria a Floresta Nacional de Caxiuana e dá outras providências. Brasília: 1961.

BRASIL. Decreto n. 241, de 29 de novembro de 1961 Parna de Brasília Cria o Parque Nacional de Brasília, no Distrito Federal, e dá outras providências. Brasília: 1961.

BRASIL. Decreto n. 242, de 29 de novembro de 1961. Cria o Parque Nacional do Monte Pascoal e dá outras providências. Brasília: 1961.

BRASIL. Decreto n. 45.954, de 30 de abril de 1959. Cria o Parque Nacional de Ubajara, Estado do Ceará. Rio de Janeiro: 1959. 
BRASIL. Decreto n. 47.446, de 17 de dezembro de 1959. Cria o Parque Nacional de Aparados da Serra, no município de São Francisco de Paula, no Estado do Rio Grande do Sul. Rio de Janeiro: 1959.

BRASIL. Decreto n. 47.570, de 31 de dezembro de 1959. Cria o Parque Nacional de Araguaia, integrante da Seção de Parques e Florestas Nacionais de

Serviço Florestal do Ministério da Agricultura. Rio de Janeiro: 1959.

BRASIL. Lei n. 1.806, de 6 de janeiro de 1953. Dispõe sobre o Plano de Valorização Econômica da Amazônia, cria a Superintendência da sua execução e dá outras providências. Rio de Janeiro: 1953.

BRASIL. Decreto n. 25.865, de 24 de novembro de 1948. Cria o Parque Nacional de Paulo Afonso. Rio São Francisco, entre Petrolina e Sobradinho: 1948.

BRASIL. Decreto-Lei n. 9.226, de 2 de maio de 1946. Cria a floresta nacional do Araripe-Apodi. Rio de Janeiro: 1946

BRASIL. Decreto-Lei n. 9.720, de 3 de setembro de 1946. Modifica o disposto nos Decretos-leis n. 4.451, de 9 de julho de 1942, e 5.185, de 12 de janeiro de 1943, relativos à constituição e atribuições do Banco de Crédito da Borracha S.A., e dá outras providências, Rio de Janeiro: 1946.

BRASIL. Decreto n. 16.677, de 29 de setembro de 1944. Aprova o Regimento do Serviço Florestal do Ministério da Agricultura. Rio de Janeiro: 1944.

BRASIL. Decreto-Lei n. 6.587, de 10 de junho de 1944. Incorpora ao Parque Nacional do Iguassu áreas que menciona. Rio de Janeiro: 1944.

BRASIL. Decreto-Lei n. 4.451, de 9 de julho de 1942. Autoriza a constituição do Banco de Crédito da Borracha, e dá outras providências. Rio de Janeiro: 1942.

BRASIL. Decreto-Lei n. 3.124, de 19 de março de 1941. Cria o Instituto Nacional do Pinho e dá outras providências. Rio de Janeiro, 1941.

BRASIL. Decreto n. 1.035, de 10 de janeiro de 1939. Cria o Parque Nacional de Iguaçu e dá outras providências. Rio de Janeiro: 1939

BRASIL. Decreto-Lei n. 1.822, de 30 de novembro de 1939. Cria o Parque Nacional da Serra dos Órgãos. Rio de Janeiro: 1939

BRASIL. Decreto-Lei n. 5.894, de 20 de outubro de 1943. Aprova e baixa o Código da Caça. Rio de Janeiro: 1938

BRASIL. Decreto-Lei n. 794, de 19 de outubro de 1938. Aprova e baixa o Código da Pesca. Rio de Janeiro: 1938

BRASIL. Decreto-Lei n. 982, de 23 de dezembro de 1938. Cria novos órgãos no Ministério da Agricultura, reagrupa e reconstitui alguns dos já existentes e dá outras providencias. Rio de Janeiro: 1938

BRASIL. Decreto n. 1.713, de 14 de junho de 1937. Cria o Parque Nacional do Itatiaia. Rio de Janeiro: 1937.

BRASIL. Decreto n. 23.793, de 23 de janeiro de 1934. Aprova o código florestal. Rio de Janeiro: 1934.

BRASIL. Decreto n. 24.642, de 10 de julho de 1934. Decreta o Código de Minas. Rio de Janeiro: 1934.

BRASIL. Decreto n. 24.643, de 10 de julho de 1934. Decreta o Código das Águas. Rio de Janeiro: 1934. 
BRASIL. Decreto n. 8.843, de 26 de julho de 1911. Cria a reserva florestal no Território do Acre. Rio de Janeiro: 1911.

\section{- Resoluções e Portarias}

INCRA. Portaria INCRA/P/N $\mathbf{N}^{\mathbf{2}} \mathbf{2 6 8}$, de 23 de outubro de 1996

BRASIL. Resolução Conama n. 12, de 14 de dezembro de 1988. Rio de Janeiro: 1988.

BRASIL. Resolução Conama n. 5, de 17 de outubro de 1990. Dispõe sobre a criação da Área de Relevante Interesse Ecológico Serra da Abelha - Rio da Prata/SC. 1990

BRASIL. Resolução Conama n. 11, de 3 de dezembro de 1987. Rio de Janeiro: 1987.

INCRA. Portaria INCRA/P/N 627, de 30 de julho de 1987.

BRASIL. Resolução Conama n. 11, de 3 de dezembro de 1987. Rio de Janeiro: 1987.

BRASIL. Resolução Conama n. 1, de 23 de janeiro de 1986. Rio de Janeiro: 1986.

BRASIL. Resolução Conama n. 10, de 10 de março de 1986. Rio de Janeiro: 1986.

BRASIL. Ministério do Interior. Resolução Conama nº 005, de 05 de junho de 1984.

BRASIL. Ministério do Interior. Resolução Conama n. 17, de 18 de dezembro de 1984. Dispõe sobre a execução de procedimentos administrativos visando a implantação da Áreas de Relevante Interesse Ecológico - Vale dos Dinossauros e Manguezais da Foz de Rio Mamanguape/PB. 1984

BRASIL. Instituto Brasileiro de Desenvolvimento Florestal. Portaria n.558, de 25 de outubro de 1968. Rio de Janeiro: 1968.

BRASIL. Instituto Brasileiro de Desenvolvimento Florestal. Portaria n.559, de 25 de outubro de 1968. Rio de Janeiro: 1968.

BRASIL. Instituto Brasileiro de Desenvolvimento Florestal. Portaria n.560, de 25 de outubro de 1968. Rio de Janeiro: 1968.

BRASIL. Instituto Brasileiro de Desenvolvimento Florestal. Portaria n.561, de 25 de outubro de 1968. Rio de Janeiro: 1968.

BRASIL. Instituto Brasileiro de Desenvolvimento Florestal. Portaria n.562, de 25 de outubro de 1968. Rio de Janeiro: 1968.

\section{- Outras fontes}

Agências de implementação da cooperação alemã para o desenvolvimento. Deutsche Gesellschaft für Internationale Zusammenarbeit (GIZ) GmbH. Disponível em: <http://www.brasil.diplo.de/Vertretung/brasilien/pt/Startseite.html > Acesso em: 08 jan. 2015

Quem é a TNC? Disponível em: 〈http://www.tnc.org.br/quem-e-a-tnc/index.htm>. Acesso em: 08 jan. 2015.

SIR Ghillean Prance 1937. Disponível em: http://www.prancefamily.co.uk/Sir Ghillean Prance.html Acesso em 06 jan. 2015. 
A Própria História dos Estados Unidos. eJOURNAL USA. Washington, DC 20547: Departamento de Estado dos EUA, v. 13. n. 7, julho de 2008, p. 11. Disponível em <http://www.america.gov/publications/ejournals.html>. Acesso em: 05 de julho de 2014.

O Planejador de Áreas Protegidas - com Keton Miller. Entrevistadores: Maria Tereza Jorge Pádua e Marc Dourojeanni. Entrevista concedida ao site O ECO. Disponível em: http://www.oeco.org.br/reportagens/10979-oeco_26884. Acesso em: 04 de dez. 2014

International Union for Conservation of Nature. About IUCN. Disponível em http://www.iucn.org/about/. Acesso em: 09 dez. 2014.

Instituto Hudson. História. Disponível em: 〈http://www.hudson.org/about/history> Acesso em: 27 dez. 2014

DEGUIGNET, M., et al. United Nations List of Protected Areas. UNEP-WXMC: Cambridge, UK, 2014. Disponível em: < http://blog.protectedplanet.net/post/102481051829/2014-united-nations-list-ofprotected-areas>. Acesso em: $15 \mathrm{dez} .2014$.

ONU. Organização das Nações Unidas. Formação da ONU. Disponível em; < http://www.batalhaosuez.com.br/onu-OrganizacaoDasNacoesUnidas.htm> Acesso em 12 nov. 2014

BRASIL. Instituto Chico Mendes de Conservação da Biodiversidade. Unidades de Conservação. Disponível em:

$<$ http://www.icmbio.gov.br/portal/biodiversidade/unidades-de-conservacao/biomasbrasileiros.html>.

BRASIL. Ministério de Meio Ambiente. Áreas Protegidas. Disponível em $<$ http://www.mma.gov.br/areas-protegidas/cadastro-nacional-de-ucs/consulta-gerarrelatorio-de-uc $>$

BRASIL. Ministério do Meio Ambiente. Biomas - Caatinga. Disponível em: <http://www.mma.gov.br/biomas/mata-atlantica>. Acesso em 22 jan. 2013.

BRASIL. Ministério do Meio Ambiente. Biomas - Cerrado. Disponível em: <http://www.mma.gov.br/biomas/cerrado>. Acesso em 24 jan. 2013.

BRASIL. Ministério do Meio Ambiente. Biomas - Mata Atlântica. Disponível em: <http://www.mma.gov.br/biomas/mata-atlantica>. Acesso em 22 jan. 2013.

FUNAI. Fundação Nacional do Ìndio. Índios no Brasil. Disponível em: <http://www.funai.gov.br/index.php/indios-no-brasil/terras-indigenas>. Acesso em 29 de agosto de 2014

IBGE. Censo Agropecuário, 1970, 1975, 1980. Disponível em <http://www.sidra.ibge.gov.br> Acesso: 27 de dez. de 2013.

OLIVEIRA, Sério Azevedo Marques de. Projeto RADAM-D - Preservação e Disseminação das Imagens originais geradas pelo Projetos RADAM e RADAMBRAIL. 2012. Disponível em <http://www.cprm.gov.br/publique/cgi/cgilua.exe/sys/start.htm?infoid=796\&sid=9> acesso em 01.05.2014. 
ORGANIZAÇÃO INTERNACIONAL DO TRABALHO. História. Brasília:

Escritório no Brasil. Disponível em: <

http://www.oitbrasil.org.br/content/hist\%C3\%B3ria>. Acesso em 13 de dezembro de 2014 (não paginado).

Word Commission on Protecte Areas - WCPA. Disponível em:

http://www.iucn.org/about/work/programmes/gpap_home/gpap_wcpa/>. Acesso em: 09 dez. 2014.

População estimada para 2013. IBGE. Instituto Brasileiro de Geografia e Estatística. Estados. Disponível em: 〈http://www.ibge.gov.br/estadosat/perfil.php?sigla=ac> Acesso em: 06/12/2013.

SOS AMAZÔNIA. Nossa História. Disponível em: http://sosamazonia.org.br/oscip/quem-somos/nossa-historia/. Acesso: 12 de nov. 2013.

\section{- Lista de Entrevistados}

Marcos Silveira, professor do Centro de Ciências Biológicas e da Natureza, da Universidade Federal do Acre. Rio Branco, 11.07.2014.

Irving Foster Brown, professor do Mestrado em Ecologia e Manejo de Recursos Naturais da Universidade Federal do Acre. Rio Branco, 02.05.2014.

Magaly da Fonseca e Silva T. Medeiros, servidora da Secretaria de Meio Ambiente do Acre. Rio Branco, 08.04.2014.

Elder Ferreira Morato, professor do Centro de Ciências Biológicas e da Natureza da Universidade Federal do Acre. Rio Branco, 02.04.2014.

Leôncio Cerqueira de Menezes, Assistente técnico em extensão rural. Cruzeiro do Sul, 24.04.2014.

Armando Muniz Calouro, professor do Centro de Ciências Biológicas e da Natureza da Universidade Federal do Acre. Rio Branco, 25.03.2014.

Moisés Barbosa de Souza, professor do Centro de Ciências Biológicas e da Natureza da Universidade Federal do Acre. Rio Branco, 31.03.2014.

Lindomar Soares Resende, professora da Universidade Federal do Acre (Campus de Cruzeiro do Sul). Cruzeiro do Sul, 23.02.2014.

Miguel Scarcello, Gestor da ONG SOS Amazônia. Rio Branco, 5.01.2014. 


\section{Referências Bibliográficas}

ALBUQUERQUE, Armando. Organização das Nações Unidas - ONU: como surgiu a ONU? p. 1-4. Disponível em: <

http://armandoalbuquerque.com/organizacoes_das_nacoes_unidas.pdf $>$. Acesso em: 05 dez. 2014.

ACRE. Governo do Estado do Acre. Programa Estadual de Zoneamento EcológicoEconômico do Estado do Acre. Zoneamento ecológico-econômico: aspectos socioeconômicos e ocupação territorial - documento final. v.2, Primeira Fase. Rio Branco: SECTMA, 2000.

ALlegretTi, Mary Helena. A Construção Social de Políticas Ambientais - Chico Mendes e o Movimento dos Seringueiros. 827f. Tese (Doutorado em Desenvolvimento Sustentável - Gestão e Política Ambiental). Brasília-DF: Universidade de Brasília, Centro de Desenvolvimento Sustentável, 2002.

ALMEIDA, Fabiana Pueza de. Histórico de Criação das Categorias de Unidades de Conservação no Brasil. 247f. Dissertação (Mestrado em Conservação da Biodiversidade e Desenvolvimento Sustentável). Nazaré Paulista-SP: Escola Superior de Conservação Ambiental e Sustentabilidade / Instituto de Pesquisas Ecológicas IPÊ, 2014.

ANDREAZZA, Mário. Programas especiais na área dos transportes: objetivos e execução. Rio de Janeiro: Companhia Brasileira de Artes Gráficas, 1972.

ARAÚJO, Marcos Antonio Reis. Unidades de Conservação no Brasil: da república à gestão de classe mundial. Belo Horizonte: SEGRAC, 2007.

BARROS, Christiane A. de S. e BUENO, Cecília. Breve Caracterização do Efeito de Borda no Parque Natural Municipal de Marapendi - Rio de Janeiro. In: VIII Congresso de Ecologia do Brasil, 2007, Caxambu-MG. Anais... Caxambu-MG:

Universidade Veiga de Almeida, Curso de Ciências Biológicas, p. 1-2, 23 a 28 de set., 2007.

BARROS, Wanderbilt Duarte de. Parques Nacionais do Brasil. Rio de Janeiro: Ministério da Agricultura/Serviço de Informação Agrícola, 1952, 88p. (Série Documentária)

BATARCE, Ana Paula Archanjo. Evolução das Unidades de Conservação no Contexto Nacional. Anais... XVI ENG, Encontro Nacional de Geógrafos - crise, práxis e autonomia: espaços de resistências e de esperanças. Porto Alegre, 25 a 31 de julho de 2010. p.1-10. p. 1.

BECKER, Berta K. Síntese do Processo de Ocupação da Amazônia: lições do passado e desafios do presente. In: BRASIL. Ministério do Meio Ambiente. Causas e Dinâmica do Desmatamento na Amazônia. Brasília: MMA, 2001, p. 5-50.

BENSUSAN, Nurit. Conservação da Biodiversidade em áreas protegidas. Rio de Janeiro: Editora FGV, 2006.

Bol. Geogr., ano 30, n. 220, p. 1-94. Rio de Janeiro: IBGE, jan/fev, 1971. 
BOLIN, Luis A. Prodígios da Natureza: os grandes parques nacionais dos Estados Unidos. (Tradução de Euzínia Rêgo Santos) Rio de Janeiro: Lidador, 1965.

BRITO, Maria Cecília Wey de. Unidades de Conservação: intenções e resultados. $2^{\mathrm{a}}$ ed. São Paulo: Annablume: Fapesp, 2003.

Brown, K. S. Jr. Geographical patterns of evolution in neotropical lepidóptera. Sustematcs and Derivation of Known and new heliconiini (Nymphalidae:

Nymphalinne), Jor. Ent.. (B), v. 44, n. 3, p. 201-242, 1975.

Brown, K. S. Jr. Geographical patterns of evolution in neotropical Lepidóptera. (Nymphalidae: Ithomiinae \& Nymphalianae-Heliconiini), Contribuição n. 19, Prog. de Ecologia. Inst. De Biologia. Universidade Estadual de Campinas -SP, Brazil. In press. Orig. manuscript, 31p., 1976.

CASTRO JR, Evaristo de; COUTINHO, Bruno Henriques; FREITAS, Leonardo Esteves de. Gestão da Biodiversidade e Áreas Protegidas. In: GUERRA, Antonio José Teixeira; \& COELHO, Maria Célia Nunes (Orgs). Unidades de Conservação: Abordagens e Características Geográficas. Rio de Janeiro: Bertrand Brasil, 2009.

CASTRO JR, Evaristo de; COUTINHO, Bruno Henriques; FREITAS, Leonardo Esteves de. Gestão da Biodiversidade e Áreas Protegidas. In: GUERRA, Antonio José Teixeira; COELHO, Maria Célia Nunes (Orgs.). Unidades de Conservação: Abordagens e Características Geográficas. Rio de Janeiro: Bertrand Brasil, 2009.

CHAPE, Start; BLYTH, Simon; FISH, Lucy FO, Phillip and SPALDING, Mark (compilers). United Nations List of Protected Areas. IUCN, Gland, Switzerland and Cambridge, UK and UNEP-WCMC, Cambridge, UK, 2003.

CHRISTOFFERSEN, Leif E. IUCN: A Bridge-Builder for Nature Conservation. p. 59-69. GREEN GLOBE YEARBOOK, 1997.

CNBB-CEP. Pastoral da Terra - posse e conflitos. Estudos da CNBB-CEP, ed. 2a . São Paulo: Edições Paulias, 1977.

COSTA SOBRINHO, Pedro Vicente. Comunicação Alternativa e Movimentos Sociais na Amazônia Ocidental. João Pessoa: Editora Universitária/UFRB, 2001.

COSTA SOBRINO, Pedro Vicente. Meios Alternativos de Comunicação e Movimentos Sociais na Amazônia Ocidental (Acre: 1971-81). 228f. Tese (Doutorado em Ciências da Comunicação). São Paulo: Programa de Pós-Graduação da Escola de Comunicação e Artes da Universidade de São Paulo-USP, 2000.

CUNHA, Luís Henrique; COELHO, Maria Célia Nunes. Política e Gestão Ambiental. In: CUNHA, Sandra Baptista da; GUERRA, Antonio José Teixeira (Orgs). A Questão Ambiental: diferentes abordagens. 8. ed. Rio de Janeiro: Bertrand Brasil, 2012. p.4379.

DANTAS, Juliana de Souza. Estado e Sociedade Civil no Acre (1970-1980). $113 \mathrm{f}$. Dissertação (Mestrado em Ciências Sociais). Natal: Universidade Federal do Rio Grande do Norte, Centro de Ciência Humanas, Letras e Artes, Programa de PósGraduação em Ciências Sociais, 2008. 
DEAN, Warren. A Ferro e Fogo: a história e a devastação da Mata Atlântica brasileira. Tradução Cid Knipel Moreira; revisão técnica de José Augusto Drummond. São Paulo: Companhia das Letras, 1996.

DEGUIGNET, Marine et. al. União Nations List of Protected Areas. UNEPWCMC: Cambridge, UK, 2014, p. 14.

DIEGUES, Antônio Carlos. O Mito Moderno da Natureza Intocada. 6. ${ }^{\text {a }}$ ed. São Paulo: Edusp/NUPAUB, 2008.

DORST, Jean. Antes que a Natureza Morra: por uma ecologia política. Tradução Rita Buongermino. São Paulo: Edgard Blücher, 1973.

DRUMMOND, José Augusto. A legislação ambiental de 1934 a 1988: comentários de um cientista ambiental simpático ao conservacionismo. Ambiente \& Sociedade, ano II, n. 3 e 4, p. $127-149,2^{\circ}$ sem. $1998,1^{\circ}$ sem.1999, p. 127-128

DRUMMOND, Jose Augusto. Devastação e Preservação Ambiental: os parques nacionais do Estado do Rio de Janeiro. Niterói: EDUFF, 1997.

DRUMMOND, Jose Augusto. National parks in Brasil: a study of 50 years of environmental policy (With Case Studies of the National Parks of the State of Rio de Janeiro). Dissertation (Masters in Environmental Studies Program), The Evergreen Satte College, Olympia, Washington, 1988, 438p.

DRUMMOND, José Augusto; DIAS, Teresa Cristina Albuquerque de Castro; e BRITO, Daguinete Maria Chaves. Atlas das Unidades de Conservação do Estado do Amapá. Macapá: MMA/IBAMA-AP; GEA/SEMA, 2008.

DUARTE, Élio Garcia. Conflitos pela Terra no Acre. Rio Branco-AC: Casa da Amazônia, 1987.

DUDLEY, Nigel (editor). Guidelines for Applying Protected Area Management Categories. Gland, Switzerland: UICN, 2008.

FRANCO, José Luis Andrade. A primeira conferência brasileira de proteção à natureza e a questão da identidade nacional. Revista Varia História, Dossiê História e Natureza, Belo Horizonte: Departamento de História UFMG, n. 26, p. 77-96, 2002.

FRANCO, José Luiz de Andrade e DRUMMOND, José Augusto. Preocupações com a proteção à natureza e com o uso dos recursos naturais na Primeira República brasileira. Textos de História, v, 12, n. 1/2, 2004. pp. 145-165.

FRANCO, Luiz de Andrade \& DRUMMOND, José Augusto. O Cuidado da Natureza: a Fundação Brasileira para a Conservação da Natureza e a experiência conservacionista no Brasil: 1958-1992. Textos de História, vol. 17, n. 1,2009, pp. 5984.

GOLO, Cristiomar. Ilegalidade de Exploração Madeireira: ação do Instituto Nacional do Pinho no Oeste Catarinense:1941-1966. Revista Tempos Acadêmicos, Universidade Federal de Santa Catarina, v. 1, n. 6, 2008. Não paginado

GÓMES-POMPA e KAUS. Domesticando o Mito da Natureza Selvagem. Bioscience, 
42(4), p. 125-147, 1992 (Trad. De Dany Patarra).

GONÇALVES, Carlos Walter Porto. Geografando nos Varadouros do Mundo: da territorialidade seringalista (o seringal) à territorialidade seringueira (a Reserva Extrativista). Brasília: Ibama, 2003.

HAFFER, Jugem. Speciation in Amazonian forest birds, Science, v. 165, n. 3889, p. 131-137, jul. 1969.

HAFFER, Jugem. Avian speciation in tropical South America. Nuttall Ornithological Club. Museum of Comparative Zoology. Harvard University Cambridge, Mass. USA (390p.), 1974.

HESS, Dora Rodrigues. Os Povos da Floresta, os Imigrantes e os Modelos de Ocupação Territorial: impactos e alternativas. Revista Brasileira de Geografia. v. 3, n. 52, p.83-89. Rio de Janeiro: IBGE, julho/setembro, 1990

IANNI, Octávio. Colonização e Contra-Reforma Agrária na Amazônia. Petrópolis: Ed. Vozez, 1979.

IBAMA. (Instituto Brasileiro de Meio Ambiente e dos Recursos Naturais Renováveis). Roteiro Metodológico para Planejamento de Unidade de Conservação de Uso Indireto. Brasília-DF: IBAMA, GTZ, 1996. 110p.

IBAMA. Instituto Brasileiro de Meio Ambiente e dos Recursos Naturais Renováveis. Roteiro Metodológico de Planejamento: Parque Nacional, Reserva Biológica, Estação Ecológica. Brasília: IBAMA, 2002. 135p

ISABEL, Rosa Maria Roldan Santana. Acre: das lutas socioambientais ao desafio de um desenvolvimento sustentável. 117f. Dissertação (Mestrado em Desenvolvimento, Agricultura e Sociedade). Seropédica-RJ: Universidade Federal Rural do Rio de Janeiro, 2001.

ISABEL, Rosa Maria Roldan Santana. Acre: das lutas socioambientais ao desafio de um desenvolvimento sustentável. 117f. Dissertação (Mestrado em Desenvolvimento, Agricultura e Sociedade). Seropédica-RJ: Universidade Federal Rural do Rio de Janeiro, 2001.

IUCN. Guidelines for Protected Área Management Categories. Gland, Switzerland and Cambridge, UK.: CNPPA with the assistance of WCMC.IUCN, 1994.

LEÃO, Regina Machado (pesquisa e edição de texto). A Floresta e o Homem. São Paulo: Editora da Universidade de São Paulo: Instituto de Pesquisas e Estudos Florestais: 2000. 458p.

LEUZINGER, Márcia Dieguez. Natureza e Cultura: unidades de conservação de proteção integral e populações tradicionais residentes. Curitiba: Letra da Lei, 2009.

LEUZINGER, Márcia Dieguez. Natureza e Cultura: unidades de conservação de proteção integral e populações tradicionais residentes. Curitiba: Letra da Lei, 2009. 280p. 
LIRA, Elisandra Moreira de; NASCIMENTO, Ivam Castro do. Sistema Estadual de Áreas Naturais Protegidas do Estado do Acre: bases para a sustentabilidade ambiental. Revista Brasileira de Ciências da Amazônia, v. 1. n. 1, p. 99-103, Rolim de MouraRO, 2012.

LISBOA, Pedro L. B. e ALMEIDA, Samuel Soares de. Vida e Obra de João Murça Reis Pires - 1917-1994. Acta bot. bras., v. 9, n. 5, p. 303-314, 1995.

MAGALHÃES, Juraci Perez. Recursos Naturais, Meio-Ambiente e sua Defesa no Direito Brasileiro. Rio de Janeiro: Ed. da Fundação Getulio Vargas: 1982.

MAIA, José Sávio da Costa. A Florestania, o Desenvolvimento (in)sustentável e as Novas Fronteiras da Sóciodiversidade no Vale do Rio Acre na Virada do Século XX: o caso dos trabalhadores extrativistas. Tese (Doutorado em História). 353f. Universidade Federal do Rio Grande do Sul: Instituto de Filosofia e Ciências Humanas, 2009.

MARTINS, José de Souza. O Poder do Atraso: ensaios de sociologia da história lenta. São Paulo: Hucitec, 1994.

McCORMICK, John. Rumo ao Paraíso - a história do movimento ambientalista (tradução de Marco Antonio Esteves da Rocha e Renato Aguiar). Rio de Janeiro: Relume-Durnarã, 1992. 224p.

MEDEIROS, Rodrigo. A Proteção da Natureza: das estratégias internacionais e nacionais às demandas locais. 391f. Tese (Doutorado em Geografia). Rio de Janeiro: Instituto de Geociências, Dept ${ }^{\circ}$ de Geografia, 2003.

MEDEIROS, Rodrigo. Evolução das Tipologias e Categorias de Áreas Protegidas no Brasil. Ambiente \& Sociedade, São Paulo, v. 9, n. 1, p. 41-64, jan./jun. 2006.

MILANO, Miguel Serediuk. Unidades de Conservação - Técnica Lei e Étia para a Conservação da Biodiversidade. In: BENJAMIM, Antônio Herman (coord.) Direito Ambiental das Áreas Protegidas: o regime jurídico das unidades de conservação. p. 3-41. Rio de Janeiro: Forense Universitária, 2001.

MILLER, K. R. Evolução do conceito de áreas de proteção - oportunidades para o século XXI. In: I Congresso Brasileiro de Unidades de Conservação, v. 1, 1997, Curitiba. Anais... Curitiba: IAP: UNILIVRE/Rede Nacional Pró Unidades de Conservação, p. 3-21, 1997.

MINISTÉRIO DO MEIO AMBIENTE. Cadernos Povos da Floresta. Rio Branco: Comitê Chico Mendes, 2003. 112p.

MORSELlO, Carla. Áreas Protegidas Públicas e Privadas: seleção e manejo. $2^{\mathrm{a}}$ ed. São Paulo: Annablume, 2008, 344p.

MOURA, Maria da Cruz Chaves Lima at. al. Conservação in situ: cenário nacional e manejo. In: PEREIRA, Telma Nair Santana (editora técnica) Germoplasma:

conservação, manejo e uso no melhoramento de plantas. Viçosa-MG: Arca, 2010. 
OLIVEIRA, Fernando Garcia de. População de Baixa Renda da Cidade de Rio Branco: situação anterior, processo migratório, formas de inserção/retribuição no mercado de trabalho. Dissertação. Rio de Janeiro, UFRJ: 1978.

OLIVEIRA, Sérgio Azevedo Marques de. Projeto RADAM-D - Preservação e Disseminação das Imagens originais geradas pelo Projetos RADAM e RADAMBRAIL. 2012. Disponível em <http://www.cprm.gov.br/publique/cgi/cgilua.exe/sys/start.htm?infoid=796\&sid=9> acesso em 01.05.2014.

PÁDUA, Maria Tereza Jorge e PORTO, Eduardo Lourenço Rocha (coord.). Plano do Sistema de Unidades de Conservação do Brasil. Brasília: IBDF, FBCN, 1979.

PANDOLFO, Clara. A Amazônia, seu Grande Potencial de Recursos Naturais e Oportunidades de Industrialização. Boletim Geográfico, ano 30, n. 221. Rio de Janeiro: IBGE, março/abril de 1971, pp. 35-95

PÁUDA, José Agusto. Um Sopro de Destruição: pensamento político e crítica ambiental no Brasil escravista (1786-1888). Rio de Janeiro: Jorge Zahar Editor, 2002.

PAULA, Elder Andrade de. (Des)Envolvimento Insustentável na Amazônia

Ocidental: dos missionários do progresso aos mercadores da natureza. Rio Branco: EDUFAC, 2005.

PEREIRA, Gustavo Simas. O Plano de Manejo e o seu Uso como Ferramenta de Gestão de Parques Nacionais no Estado do Rio de Janeiro. Dissertação (Mestrado em Ciências Ambientais e Florestais). 115f. Seropédica-RJ: Universidade Federal Rural do Rio de Janeiro, Instituto de Florestas, 2009.

PRANCE, Ghillean Tolmie. Phytogeographic support for the theory of Pleistocene forest refuges in the Amazon Basin, based on evidence fron Dichapetalaceae and Lecythidaceae. Acta Amazonica,v. 3, n. 3, p. 5-28, INPA/CNPq., 1973.

QUINTÃO, Angela Tresinari B. Evolução do Conceito de Parques Nacionais e sua relação com o processo de desenvolvimento. Brasil Florestal, n. 54, Ano XII, p. 1327, abr/mai/jun., 1983.

RIBEIRO, Wagner Costa. A Ordem Ambiental Internacional. 2a ed. São Paulo: Contexto, 2010.

SCHMINK, Marianne \& WOOD, Charles H. Conflitos Sociais e a Formação da Amazônia. Tradução de Noemi Miyasaka Porro e Raimundo Mourta. Belém: Ed. UFPA, 2012.

SEGAWA, Hugo M. Ao Amor do Público: jardins no Brasil (1779-1911). Tese (Doutorado em Arquitetura e Urbanismo). 201f. São Paulo: Faculdade de Arquitetura e Urbanismo da Universidade de São Paulo, 1994.

SILVA, Maria do Socorro Ferreira \& SOUZA, Rosemeri Melo. Unidades de Conservação como estratégia de gestão territorial dos recursos naturais.

Terra@Plural, Ponta Grossa, v.3, n. 2, jul./dez. 2009, p. 241-259. 
SOARES, Guido Fernando Silva. A Proteção internacional do meio ambiente. Barueri-SP: Monole, 2003.

SOBREVILLA, C.; BATH, P. Evaluación ecológica rápida: um manual para usuários de América Latina y el Caribe. Washington: The Nature Conservancy, 1992.

SOUZA, Nádia Simas. A Amazônia brasileira: processo de ocupação e a devastação da floresta. Boletim Científico ESMPU, Brasília, ano 9, n. 32/33, p. 199-235, jan./dez. 2010.

SOUZA, Rosemeri Melo. Unidades de Conservação como estratégia de gestão territorial dos recursos naturais. Terra@ Plural, Ponta Grossa, v. 3, n. 2, p. 241-259, jul./dez. 2009.

TEIXEIRA, Orci Paulino Bretanha. O Direito ao Meio Ambiente Ecologicamente equilibrado como Direito Fundamental. Porto Alegre: Livraria do Advogado, Ed., 2006.

TERBORGH, John. de Noé ou porque precisamos de parques. Natureza \& Conservação. v. 1, n. 2, p. 9-15, out. 2003, p 09-10.

URBAN, Tereza. Saudade do Matão: relembrando a história da conservação da natureza no Brasil. Curitiva: Editora da UFPR; Fundação O Boticário de Proteção à Natureza; Fundação MarArthur, 1998.

VALLEJO, Luiz Renato. Os Parques e Reservas como Instrumentos do Ordenamento Territorial. In: ALMEIDA, Flávio Gomes \& SOARES, Luiz Antônio Soares (Orgs.). Ordenamento Territorail: coletânea de textos com diferentes abordagens no contexto brasileiro. Rio de Janeiro: Bertrand Brasil, 2009. p.157-194.

VALLEJO, Luiz Renato. Unidades de Conservação: uma discussão teórica à luz dos conceitos de território e de políticas públicas. Geographia, v. 4, n. o 8, p. 57-78, 2002.

VALVERDE, Orlando. A Devastação da Floresta Amazônica. Revista Brasileira de Geografia. v. 3, n. 52, p. 11-24. Rio de Janeiro: IBGE, julho/setembro, 1990.

VANZOLINI, Paulo Emílio and WILLIAMS, Ernest E. South American anoles: the geographic differentation and evolution of the Anolis chrysolepis species group (Sauri, Iguanidae), Arq. Zool. v. 19, p. 1-240, São Paulo.

VANZOLINI, Paulo Emílio. Zoologia sistemática, geografia e a origem das espécies. São Paulo: Universidade de São Paulo (Série Teses e Monografias IG, n. 3, 56p).

VELHO, Otávio Guilherme. Capitalismo autoritário e campesinato. Rio de Janeiro: Difel, 1979.

VERÍSSIMO, Adalberto; SOUZA Jr., Carlos, SALOMÃO, Rodney. Identificação de Áreas com Potencial para a criação de Florestas Estaduais no Estado do Acre.

Relatório Final. Belém: IMAZON e Governo do Estado do Acre, 2002.

VIANNA, Lucila Pinsard. De Invisíveis a Protagonistas: populações tradicionais e unidades de conservação. São Paulo: Annablume/Fapesp, 2008. 
VIANNA, Regina Cerece. A Liga das Nações e a ONU - Na busca da paz, do Direito, da Justiça e da vida. Revista Âmbito Jurídico, n. 83, ano XIII, dez. de 2010 (não paginado).

WING, H. Races of Drosophila willistoni sibling species: probable origin in quaternary forest refuges of. S. America. Genetics, v. 74, p. 297-298 (Suppl.), 1973. 
ANEXOS 
Tabela 2 Matriz dos objetivos e categorias de gestão de das áreas protegidas segundo a UICN em 1994

\begin{tabular}{|c|c|c|c|c|c|c|c|}
\hline \multirow[b]{2}{*}{ OBJETIVO DE GESTÃO } & \multicolumn{7}{|c|}{$\begin{array}{l}\text { CATEGORIAS DE UNIDADES DE } \\
\text { CONSERVAÇÃO DA UICN }\end{array}$} \\
\hline & Ia & Ib & II & III & IV & $\mathbf{V}$ & VI \\
\hline Pesquisa científica & 1 & 3 & 2 & 2 & 2 & 2 & 3 \\
\hline Proteção de áreas virgens & 2 & 1 & 2 & 3 & 3 & - & 1 \\
\hline Preservação de espécies e diversidade genética & 1 & 2 & 1 & 1 & 1 & 2 & 1 \\
\hline Manutenção de serviços ambientais & 1 & 2 & 1 & - & 1 & 2 & 1 \\
\hline Proteção de características naturais e culturais específicas & - & - & 2 & 1 & 3 & 1 & 3 \\
\hline Turismo e lazer & - & 2 & 1 & 1 & 3 & 1 & 3 \\
\hline Educação & - & - & 2 & 2 & 2 & 2 & 3 \\
\hline Uso sustentável de recursos dos ecossistemas & - & - & - & - & - & 1 & 2 \\
\hline $\begin{array}{l}\text { Chave: } \\
1 \text { = Objetivo principal } \\
2 \text { = Objetivo secundário } \\
3 \text { = Possível objetivo aplicável } \\
\text { - = não aplicável }\end{array}$ & & & & & & & \\
\hline
\end{tabular}

Tabela 3 Áreas Protegidas criadas no Brasil, por Estado e Biomas, no período de 1937 a 1961

\begin{tabular}{|c|c|c|c|c|c|}
\hline N. ${ }^{\circ}$ & NOME & CRIAÇÃO & ÁREA/Ha & ESTADO(S) & BIOMA \\
\hline 01 & $\begin{array}{l}\text { Parque Nacional do } \\
\text { Itatiaia }\end{array}$ & $\begin{array}{l}\text { Dec } \mathrm{n}^{\circ} 1.713 \text { de } 14 \text { de } \\
\text { junho de } 1937\end{array}$ & $11.943,00$ & $\begin{array}{l}\text { Rio de Janeiro e } \\
\text { Minas Gerais }\end{array}$ & $\begin{array}{c}\text { Mata } \\
\text { Atlântica }\end{array}$ \\
\hline 02 & $\begin{array}{l}\text { Parque Nacional do } \\
\text { Iguaçu }\end{array}$ & $\begin{array}{l}\text { Dec Lei } \mathrm{n}^{\circ} 1.035 \text { de } \\
10 \text { de janeiro de } 1939\end{array}$ & $185.262,50$ & Paraná & $\begin{array}{c}\text { Mata } \\
\text { Atlântica }\end{array}$ \\
\hline 03 & $\begin{array}{l}\text { Parque Nacional da } \\
\text { Serra dos Órgãos }\end{array}$ & $\begin{array}{l}\text { Dec } \mathrm{n}^{\circ} 1.822 \text { de } 30 \text { de } \\
\text { novembro de } 1939\end{array}$ & $10.000,00$ & Rio de Janeiro & $\begin{array}{c}\text { Mata } \\
\text { Atlântica }\end{array}$ \\
\hline 04 & $\begin{array}{l}\text { Floresta Nacional } \\
\text { Araripe-Apodi }\end{array}$ & $\begin{array}{l}\text { Dec-Lei } n^{\circ} 9.226 \text { de } \\
02 \text { de maio de } 1946\end{array}$ & $38.331,00$ & $\begin{array}{c}\text { Ceará, } \\
\text { Pernambuco, } \\
\text { Piauí, Rio Grande } \\
\text { do Norte }\end{array}$ & Caatinga \\
\hline 05 & $\begin{array}{l}\text { Parque Nacional de } \\
\text { Paulo Afonso } * * * * *\end{array}$ & $\begin{array}{l}\text { Dec. n. } 25.865 \text { de } 24 \\
\text { de novembro de } 1948\end{array}$ & $16.865,42$ & $\begin{array}{l}\text { Alagoas, } \\
\text { Pernambuco, e } \\
\text { Bahia }\end{array}$ & Caatinga \\
\hline 06 & Parna de Ubajara & $\begin{array}{l}\text { Dec } n^{\circ} 45.954 \text { de } 30 \\
\text { de abril de } 1959\end{array}$ & $4.000,00$ & Ceará & Caatinga \\
\hline 07 & $\begin{array}{l}\text { Parna de Aparados } \\
\text { da Serra }\end{array}$ & $\begin{array}{l}\text { Dec } n^{\circ} 47.446 \text { de } 17 \\
\text { de dezembro de } 1959\end{array}$ & $13.000,00$ & $\begin{array}{l}\text { Rio Grande do } \\
\text { Sul e Santa } \\
\text { Catarina }\end{array}$ & $\begin{array}{l}\text { Mata } \\
\text { Atlântica }\end{array}$ \\
\hline 08 & Parna do Araguaia & $\begin{array}{l}\text { Dec } n^{\circ} 47.570 \text { de } 31 \\
\text { de dezembro de } 1959\end{array}$ & $2.000 .000,00$ & $\begin{array}{l}\text { Goiás (hoje } \\
\text { Tocantins) }\end{array}$ & Cerrado \\
\hline 09 & $\begin{array}{l}\text { Parna da Chapada } \\
\text { dos Veadeiros }\end{array}$ & $\begin{array}{l}\text { Dec } n^{\circ} 49.875 \text { de } 11 \\
\text { de janeiro de } 1961 / \\
\text { Dec } n^{\circ} 70.492 \text { de } 11 \\
\text { de maio de } 1972 \text {. }\end{array}$ & $171.924,54$ & Goiás & Cerrado \\
\hline 10 & Parna das Emas & $\begin{array}{l}\text { Dec } n^{\circ} 49.874 \text { de } 11 \\
\text { de janeiro } \\
\text { 1961/Dec } n^{\circ} 70.375 \\
\text { de 06 de abril de } \\
\text { 1972. }\end{array}$ & $100.000,00$ & $\begin{array}{l}\text { Mato Grosso do } \\
\text { Sul e Goiás }\end{array}$ & Cerrado \\
\hline 11 & Parna do Caparaó & $\begin{array}{l}\text { Dec no } 50646 \text { de } 24 \\
\text { de maio de } 1961\end{array}$ & $31.762,93$ & $\begin{array}{l}\text { Espírito Santo e } \\
\text { Minas Gerais }\end{array}$ & $\begin{array}{l}\text { Mata } \\
\text { Atlântica }\end{array}$ \\
\hline 12 & $\begin{array}{l}\text { Parna de Sete } \\
\text { Cidades }\end{array}$ & $\begin{array}{l}\text { Dec no } 50.744 \text { de } 8 \text { de } \\
\text { junho de } 1961\end{array}$ & $7.700,00$ & Piauí & Caatinga \\
\hline
\end{tabular}




\section{Parna da Tijuca}

\begin{tabular}{|c|c|c|c|c|c|}
\hline 13 & Parna da Tijuca & $\begin{array}{l}\text { Dec } \mathrm{n}^{\circ} 50.923 \text { de } 06 \\
\text { de julho de } 1961 / \text { Dec } \\
\mathrm{n}^{\circ} 60.183 \text { de } 28 \text { de } \\
\text { fevereiro de } 1967 / \\
\text { Dec n } 70.186 \text { de } 23 \\
\text { de fevereiro de } 1972\end{array}$ & $3.200,00$ & Rio de Janeiro & $\begin{array}{l}\text { Mata } \\
\text { Atlântica }\end{array}$ \\
\hline 14 & $\begin{array}{l}\text { Parna de São } \\
\text { Joaquim }\end{array}$ & $\begin{array}{l}\text { Dec } n^{\circ} 50.922 \text { de } 06 \\
\text { de julho de } 1961\end{array}$ & $49.300,00$ & Santa Catarina & $\begin{array}{c}\text { Mata } \\
\text { Atlântica }\end{array}$ \\
\hline 15 & $\begin{array}{l}\text { Floresta Nacional } \\
\text { de Caxiuanã }\end{array}$ & $\begin{array}{l}\text { Dec } n^{\circ} 239 \text { de } 28 \text { de } \\
\text { novembro de } 1961\end{array}$ & $200.000,00$ & Pará & Amazônia \\
\hline 16 & Parna de Brasília & $\begin{array}{l}\text { Dec }^{\circ} 241 \text { de } 29 \text { de } \\
\text { novembro de } 1961\end{array}$ & $30.000,00$ & Distrito Federal & Cerrado \\
\hline 17 & $\begin{array}{l}\text { Parna Histórico do } \\
\text { Monte Pascoal }\end{array}$ & $\begin{array}{l}\text { Dec no } 242 \text { de } 29 \text { de } \\
\text { novembro de } 1961 /\end{array}$ & $22.500,00$ & Bahia & $\begin{array}{c}\text { Mata } \\
\text { Atlântica }\end{array}$ \\
\hline
\end{tabular}

Tabela 4 Zonas características do zoneamento de um Parque, segundo Decreto n ${ }^{\circ} 84.017$ de 1979 que regulamentou os Parques Nacionais no Brasil.

\begin{tabular}{cl}
\hline ZONAS & \multicolumn{1}{c}{ CARACTERÍSTICAS } \\
\hline I - Intangível & $\begin{array}{l}\text { É aquela onde a primitividade da natureza permanece intacta, não se tolerando } \\
\text { quaisquer alterações humanas, representando o mais alto grau de preservação. }\end{array}$ \\
& $\begin{array}{l}\text { Funciona como matriz de repovoamento de outras zonas onde já são permitidas } \\
\text { atividades humanas regulamentadas. Esta zona é dedicada à proteção integral de }\end{array}$ \\
& ecossistemas, dos recursos genéticos e ao monitoramento ambiental. O objetivo \\
básico do manejo é a preservação garantindo a evolução natural;
\end{tabular}


obras no ambiente natural ou cultural do Parque;

Fonte: BRASIL. Decreto $\mathbf{n}^{\mathbf{0}}$ 84.017, de 21 de setembro de 1979. Aprova o Regulamento dos Parques Nacionais Brasileiros. Brasília: 1979.

Tabela 5 Objetivos de manejo do Sistema Brasileiro de Unidades de Conservação de 1979

\begin{tabular}{cl}
\hline $\mathbf{N}^{\mathbf{0}}$ & \multicolumn{1}{c}{ OBJETIVOS } \\
\hline 1 & $\begin{array}{l}\text { Proteger amostras de toda diversidade de ecossistemas do país, assegurando o processo } \\
\text { evolutivo; }\end{array}$ \\
& $\begin{array}{l}\text { Proteger espécies raras, em perigo ou ameaçadas de extinção, biótopos, comunidades } \\
\text { bióticas únicas, formações geológicas e geomorfológicas de relevante valor, paisagens de } \\
\text { rara beleza cênica, objetivando garantir a auto-regulação do meio ambiente, como também } \\
\text { um meio diversificado; }\end{array}$ \\
3 & $\begin{array}{l}\text { Preservar o patrimônio genético, objetivando a redução das taxas de extinção de espécies a } \\
\text { níveis naturais; }\end{array}$ \\
4 & $\begin{array}{l}\text { Proteger a produção hídrica minimizando a erosão, a sedimentação, especialmente quanto } \\
\text { afeta atividades que dependem da utilização da água ou do solo; }\end{array}$ \\
5 & $\begin{array}{l}\text { Proteger os recursos da flora e fauna quer seja pela sua importância genética ou pelo seu } \\
\text { valor econômico, obtenção de proteínas ou para atividades de lazer; }\end{array}$ \\
Conservar paisagens de relevantes belezas cênicas naturais ou alteradas, mantidas a um nível \\
sustentável, visando a recreação e turismo; \\
Conservar valores culturais, históricos e arqueológicos - patrimônio cultural da nação - para \\
a investigação e visitação; \\
$\begin{array}{l}\text { Preservar grandes áreas provisoriamente até que estudos futuros indiquem sua melhor } \\
\text { utilização, seja como uma unidade de conservação, ou para a agricultura, ou pecuária, ou } \\
\text { qualquer outro fim. É um objetivo exclusivo indicando a Reserva de Recursos (Reservas }\end{array}$ \\
$\begin{array}{l}\text { Florestas); } \\
\text { Levar o desenvolvimento através da conservação a regiões até então pouco desenvolvidas; } \\
11\end{array}$ & $\begin{array}{l}\text { Proporcionar condições de monitoramento ambiental; } \\
\text { Proporcionar meios para a educação, investigação, estudos e divulgação sobre os recursos } \\
\text { naturais; e }\end{array}$ \\
Fomentar o uso racional os recursos naturais, através de áreas de uso múltiplo (Jorge Pádua, \\
1977)
\end{tabular}

Tabela 6 Categorias de Manejo do I Plano do Sistema de Unidades de Conservação do Brasil - 1979

\begin{tabular}{|c|c|c|}
\hline CATEGORIA/GRUPO & CARACTERÍSTICAS & $\begin{array}{c}\text { UNIDADES DE } \\
\text { CONSERVAÇÃO }\end{array}$ \\
\hline $\begin{array}{lcc}\text { I } & - & \text { Categoria } \\
\text { Importância Nacional }\end{array}$ & $\begin{array}{l}\text { Total proteção dos recursos naturais; uso } \\
\text { indireto dos recursos naturais; manter os } \\
\text { ecossistemas ou parcelas dos mesmos em } \\
\text { estado natural, observando-se sua } \\
\text { evolução; as terras devem pertencer ao } \\
\text { Poder Público, no entanto no caso } \\
\text { específico de Santuário de Vida Silvestre, } \\
\text { nem sempre é necessária a aquisição pelo } \\
\text { Poder Público. }\end{array}$ & $\begin{array}{l}\text { Parque Nacional; Reserva } \\
\text { Científica ou Biológica; } \\
\text { Monumento Natural; e } \\
\text { Santuário ou Refúgio da } \\
\text { Vida Silvestre. }\end{array}$ \\
\hline $\begin{array}{l}\text { II - Categoria de Manejo } \\
\text { Complementares }\end{array}$ & $\begin{array}{l}\text { Proteção parcial dos recursos naturais; uso } \\
\text { indireto; ambiente podendo apresentar } \\
\text { alterações antrópicas; e as terras em sua } \\
\text { totalidade podem pertencer ao governo ou } \\
\text { somente parte delas. }\end{array}$ & $\begin{array}{l}\text { Estação Ecológica; Rio } \\
\text { Cênico; Rodovia Parque; e } \\
\text { Reserva de Recursos } \\
\text { (Reservas Florestais). }\end{array}$ \\
\hline $\begin{array}{l}\text { III - Categoria de Manejo } \\
\text { Adicionais }\end{array}$ & $\begin{array}{l}\text { Uso direto racional dos recursos, com } \\
\text { manejo sustentável; as terras podem ser do } \\
\text { governo ou de propriedade mista; e não }\end{array}$ & $\begin{array}{lr}\text { Parque Natural; } & \text { Florestas } \\
\text { Nacionais; } & \text { Reserva } \\
\text { Indígena; Reserva de Fauna; }\end{array}$ \\
\hline
\end{tabular}


IV - Categoria de Manejo Regionais ou Locais

V - Categoria de Manejo de Importância Mundial são consideradas unidades de conservação na total concepção do termo, mas podem contribuir para o sistema.

São pertencentes a outros níveis de Governo: Estadual e Municipal

Este grupo encontra-se em fase de estudos pelo Brasil.
Parque de Caça; e Monumento Cultural ( Sítios históricos).

Parque Estadual; Parque Municipal; Reserva

Biológica Estadual; Reserva Biológica Municipal; Parques de Caça Estaduais; Parques de Caça Municipais; e outros.

Reserva da Biosfera; Reserva de Patrimônio Mundial (World Heritage Site) (Jorge Pádua, 1978)

Fonte: PÁDUA \& PORTO, 1979, p. 10-11.

Tabela 7 Evolução das Unidades de Conservação no Brasil: 1968 a 1985

\begin{tabular}{|c|c|c|c|c|c|}
\hline $\mathbf{N}^{\mathbf{o}}$ & NOME & CRIAÇÃO & ÁREA/Ha & ESTADO(S) & BIOMA \\
\hline 01 & $\begin{array}{l}\text { Flona de Capão } \\
\text { Bonito }\end{array}$ & $\begin{array}{l}\text { Portaria } \mathrm{n}^{\circ} 558 \text { de } 25 \text { de } \\
\text { outubro de } 1968\end{array}$ & $4.344,00$ & São Paulo & Mata Atlântica \\
\hline 02 & Flona de Irati & $\begin{array}{l}\text { Portaria } n^{\circ} 559 \text { de } 25 \text { de } \\
\text { outubro de } 1968\end{array}$ & $3.495,00$ & Paraná & Mata Atlântica \\
\hline 03 & Flona do Açungui & $\begin{array}{l}\text { Portaria } n^{\circ} 559 \text {, de } 25 \text { de } \\
\text { outubro de } 1968\end{array}$ & 728,00 & Paraná & Mata Atlântica \\
\hline 04 & $\begin{array}{l}\text { Flona de Três } \\
\text { Barras }\end{array}$ & $\begin{array}{l}\text { Portaria } n^{\circ} 560 \text { de } 25 \text { de } \\
\text { outubro de } 1968\end{array}$ & $4.458,00$ & $\begin{array}{c}\text { Santa } \\
\text { Catarina }\end{array}$ & Mata Atlântica \\
\hline 05 & Flona de Chapecó & $\begin{array}{l}\text { Portaria } \mathrm{n}^{\circ} 560 \text { de } 25 \text { de } \\
\text { outubro de } 1968 \text {. }\end{array}$ & $1.606,00$ & $\begin{array}{c}\text { Santa } \\
\text { Catarina }\end{array}$ & Mata Atlântica \\
\hline 06 & Flona de Caçador & $\begin{array}{l}\text { Portaria n } 560 \text { de } 25 \text { de } \\
\text { outubro de } 1968\end{array}$ & 710,00 & $\begin{array}{c}\text { Santa } \\
\text { Catarina }\end{array}$ & Mata Atlântica \\
\hline 07 & Flona de Canela & $\begin{array}{l}\text { Portaria } n^{\circ} 561 \text {, de } 25 \text { de } \\
\text { outubro de } 1968 \text {. }\end{array}$ & 517,00 & $\begin{array}{l}\text { Rio Grande } \\
\text { do Sul }\end{array}$ & Mata Atlântica \\
\hline 08 & $\begin{array}{l}\text { Flona de São } \\
\text { Francisco de Paula }\end{array}$ & $\begin{array}{l}\text { A Portaria } n^{\circ} 561 \text {, de } 25 \\
\text { de outubro de } 1968\end{array}$ & $1.606,00$ & $\begin{array}{l}\text { Rio Grande } \\
\text { do Sul }\end{array}$ & Mata Atlântica \\
\hline 09 & $\begin{array}{l}\text { Flona de Passo } \\
\text { Fundo }\end{array}$ & $\begin{array}{l}\text { Portaria n } 561 \text { de } 25 \text { de } \\
\text { outubro de } 1968\end{array}$ & $1.328,00$ & $\begin{array}{l}\text { Rio Grande } \\
\text { do Sul }\end{array}$ & Mata Atlântica \\
\hline 10 & $\begin{array}{l}\text { Flona de Passa } \\
\text { Quatro }\end{array}$ & $\begin{array}{l}\text { Portaria } n^{\circ} 562 \text { de } 25 \text { de } \\
\text { outubro de } 1968\end{array}$ & 335,00 & Minas Gerais & Mata Atlântica \\
\hline 11 & $\begin{array}{l}\text { Parna da Serra da } \\
\text { Bocaina }\end{array}$ & $\begin{array}{l}\text { Dec } n^{\circ} 68.172 \text { de } 04 \text { de } \\
\text { fevereiro de } 1971 / \text { Dec } n^{\circ} \\
70.694 \text { de } 08 \text { de junho de } \\
1972\end{array}$ & $100.000,00$ & $\begin{array}{c}\text { Rio de } \\
\text { Janeiro e São } \\
\text { Paulo }\end{array}$ & Mata Atlântica \\
\hline 12 & $\begin{array}{l}\text { Parna da Serra da } \\
\text { Canastra }\end{array}$ & $\begin{array}{l}\text { Dec no } 70.355 \text { de } 03 \text { de } \\
\text { abril de } 1972\end{array}$ & $200.000,00$ & Minas Gerais & Cerrado \\
\hline 13 & Parna da Amazônia & $\begin{array}{l}\text { Dec no } 73.683 \text { de } 19 \text { de } \\
\text { fevereiro de } 1974\end{array}$ & $1.000 .000,00$ & $\begin{array}{c}\text { Pará e } \\
\text { Amazonas }\end{array}$ & Amazônia \\
\hline 14 & $\begin{array}{l}\text { Floresta Nacional } \\
\text { do Tapajós }\end{array}$ & $\begin{array}{l}\text { Dec } n^{\circ} 73.684 \text { de } 19 \text { de } \\
\text { fevereiro de } 1974 \text {. }\end{array}$ & $600.000,00$ & Pará & Amazônia \\
\hline 15 & $\begin{array}{l}\text { Rebio de Poço das } \\
\text { Antas }\end{array}$ & $\begin{array}{l}\text { Decreto } \mathrm{n}^{\circ} 73.791, \text { de } \\
11.03 .1974\end{array}$ & $3.000,00$ & $\begin{array}{l}\text { Rio de } \\
\text { Janeiro }\end{array}$ & Mata Atlântica \\
\hline 16 & $\begin{array}{l}\text { Parna da Serra da } \\
\text { Capivara }\end{array}$ & $\begin{array}{l}\text { Dec } n^{\circ} 83.548 \text { de } 05 \text { de } \\
\text { junho de } 1979\end{array}$ & $100.000,00$ & Piauí & Caatinga \\
\hline 17 & $\begin{array}{l}\text { Rebio Atol das } \\
\text { Rocas }\end{array}$ & $\begin{array}{l}\text { Dec } n^{\circ} 83.549 \text { de } 05 \text { de } \\
\text { junho de } 1979\end{array}$ & $36.249,00$ & $\begin{array}{l}\text { Rio Grande } \\
\text { do Norte }\end{array}$ & $\begin{array}{l}\text { Marinho } \\
\text { Costeiro }\end{array}$ \\
\hline 18 & Parna do Pico da & Dec $\mathrm{n}^{\circ} 83.550$ de 05 de & 2.200.000,00 & Amazonas & Amazônia \\
\hline
\end{tabular}




\begin{tabular}{|c|c|c|c|c|c|}
\hline & Neblina & junho de 1979 & & & \\
\hline 19 & Rebio do Jaru & $\begin{array}{l}\text { Dec } n^{\circ} 83.716 \text { de } 11 \text { de } \\
\text { julho de } 1979\end{array}$ & $268.150,00$ & Rondônia & Amazônia \\
\hline 20 & $\begin{array}{l}\text { Rebio do Rio } \\
\text { Trombetas }\end{array}$ & $\begin{array}{l}\text { Dec } n^{\circ} 84.018 \text { de } 21 \text { de } \\
\text { setembro de } 1979 .\end{array}$ & $385.000,00$ & Pará & Amazônia \\
\hline 21 & $\begin{array}{l}\text { Parna de Pacaás } \\
\text { Novos }\end{array}$ & $\begin{array}{l}\text { Dec n } 84019 \text { de } 21 \text { de } \\
\text { Setembro } \\
1979\end{array}$ & $764.801,00$ & Rondônia & Amazônia \\
\hline 22 & $\begin{array}{l}\text { Parna do Cabo } \\
\text { Orange }\end{array}$ & $\begin{array}{l}\text { Dec } n^{\circ} 84.913 \text { de } 15 \text { de } \\
\text { julho de } 1980\end{array}$ & $619.000,00$ & Amapá & Amazônia \\
\hline 23 & $\begin{array}{ll}\text { Rebio } & \text { Lago } \\
\text { Piratuba } & \end{array}$ & $\begin{array}{l}\text { Dec no } 84.914 \text { de } 16 \text { de } \\
\text { julho de } 1980\end{array}$ & $395.000,00$ & Amapá & Amazônia \\
\hline 24 & Parna do Jaú & $\begin{array}{l}\text { Dec }^{\circ} 85.200 \text { de } 24 \text { de } \\
\text { setembro de } 1980\end{array}$ & $2.272 .000,00$ & Amazonas & Amazônia \\
\hline 25 & Rebio de Una & $\begin{array}{l}\text { Dec } n^{\circ} 85.463 \text { de } 10 \text { de } \\
\text { dezembro de } 1980\end{array}$ & $11.400,00$ & Bahia & Mata Atlântica \\
\hline 26 & $\begin{array}{l}\text { Parna dos Lençois } \\
\text { Maranhenses }\end{array}$ & $\begin{array}{l}\text { Dec } n^{\circ} 86.060 \text { de } 02 \text { de } \\
\text { junho de } 1981\end{array}$ & 155.000 & Maranhão & $\begin{array}{l}\text { Marinho } \\
\text { Costeiro }\end{array}$ \\
\hline 27 & $\begin{array}{l}\text { Esec de Aracuri- } \\
\text { Esmeralda }\end{array}$ & $\begin{array}{l}\text { Dec } s / n^{\circ} \text { de } 02 \text { de junho } \\
\text { de } 1981\end{array}$ & 272,62 & $\begin{array}{l}\text { Rio Grande } \\
\text { do Sul }\end{array}$ & Mata Atlântica \\
\hline 28 & Esec de Taiamã & $\begin{array}{l}\text { Dec } s / n^{\circ} \text { de } 02 \text { de junho } \\
\text { de } 1981\end{array}$ & $11.200,00$ & Mato Grosso & Pantanal \\
\hline 29 & Esec de Maracá & $\begin{array}{l}\text { Dec } s / n^{\circ} \text { de } 02 \text { de junho } \\
\text { de } 1981\end{array}$ & $101.312,00$ & Roraima & Amazônia \\
\hline 30 & $\begin{array}{l}\text { Esec de Uruçuí- } \\
\text { Una }\end{array}$ & $\begin{array}{l}\text { Dec } s / n^{\circ} \text { de } 02 \text { de junho } \\
\text { de } 1981\end{array}$ & $135.000,00$ & Piauí & Cerrado \\
\hline 31 & $\begin{array}{l}\text { Esec de Maracá- } \\
\text { Jipioca }\end{array}$ & $\begin{array}{l}\text { Dec } s / n^{\circ} \text { de } 02 \text { de junho } \\
\text { de } 1981\end{array}$ & $72.000,00$ & Amapá & Amazônia \\
\hline 32 & Esec de Iquê & $\begin{array}{l}\text { Decreto } \mathrm{n}^{\mathrm{o}} 86061, \mathrm{de} \\
02 / 06 / 1981\end{array}$ & $200.000,00$ & Mato Grosso & Cerrado \\
\hline 33 & Esec do Rio Acre & $\begin{array}{l}\text { Decreto } n^{\circ} 86.061 \text {, de } 2 \text { de } \\
\text { junho de } 1981\end{array}$ & $77.500,00$ & Acre & Amazônia \\
\hline 34 & $\begin{array}{ll}\text { Esec } & \text { de } \\
\text { Anavilhanas } & \end{array}$ & $\begin{array}{l}\text { Dec } \mathrm{n}^{\circ} 86.061 \text { de } 02 \text { de } \\
\text { junho de } 1981\end{array}$ & $350.018,00$ & Amazonas & Amazônia \\
\hline 35 & $\begin{array}{l}\text { Parna do Pantanal } \\
\text { Matogrossense }\end{array}$ & $\begin{array}{l}\text { Dec } n^{\circ} 86.392 \text { de } 24 \text { de } \\
\text { setembro de } 1981\end{array}$ & $135.000,00$ & Mato Grosso & Pantanal \\
\hline 36 & Esec do Jari & $\begin{array}{l}\text { Dec no } 87.092 \text { de } 12 \text { de } \\
\text { abril de } 1982 / \text { Dec } \text { n }^{\circ} \\
89.440 \text { de } 13 \text { de março de } \\
1984\end{array}$ & $227.126,00$ & Pará/Amapá & Amazônia \\
\hline 37 & Esec do Seridó & $\begin{array}{l}\text { Dec } n^{\circ} 87.222 \text { de } 31 \text { de } \\
\text { maio de } 1982\end{array}$ & $1.166,38$ & $\begin{array}{l}\text { Rio Grande } \\
\text { do Norte }\end{array}$ & Caatinga \\
\hline 38 & $\begin{array}{ll}\text { Esec } & \text { de } \\
\text { Guaraqueçaba } & \end{array}$ & $\begin{array}{l}\text { Dec } n^{\circ} 87.222 \text { de } 31 \text { de } \\
\text { maio de } 1982 / \text { Dec } n^{\text {o }} \\
93.053 \text { de } 31 \text { de julho de } \\
1986 /\end{array}$ & $13.653,93$ & Paraná & $\begin{array}{l}\text { Marinho } \\
\text { Costeiro }\end{array}$ \\
\hline 39 & $\begin{array}{l}\text { Esec Serra das } \\
\text { Araras }\end{array}$ & $\begin{array}{l}\text { Dec }^{\circ} 87.222 \text { de } 31 \text { de } \\
\text { maio de } 1982\end{array}$ & $28.700,00$ & Mato Grosso & Cerrado \\
\hline 40 & Esec de Caracaraí & $\begin{array}{l}\text { Dec } n^{\circ} 87.222 \text { de } 31 \text { de } \\
\text { maio de } 1982\end{array}$ & $80.560,00$ & Roraima & Amazônia \\
\hline 41 & $\begin{array}{l}\text { Rebio } \\
\text { Sooretama }\end{array}$ & $\begin{array}{l}\text { Dec }^{\circ} 87.588 \text { de } 20 \text { de } \\
\text { setembro de } 1982\end{array}$ & $24.000,00$ & $\begin{array}{l}\text { Espírito } \\
\text { Santo }\end{array}$ & Mata Atlântica \\
\hline 42 & APA de Petrópolis & $\begin{array}{l}\text { Dec n } n^{\circ} 87.561 \text {, de } 13 \text { de } \\
\text { setembro de } 1982 / \text { Área } \\
\text { definda pelo Dec } 527 \text { de } \\
20 \text { de maio de } 1992\end{array}$ & $59.049,00$ & $\begin{array}{l}\text { Rio de } \\
\text { Janeiro }\end{array}$ & Mata Atlântica \\
\hline 43 & $\begin{array}{l}\text { APA Mananciais } \\
\text { do Rio Paraíba do } \\
\text { Sul }\end{array}$ & $\begin{array}{l}\text { Dec } \mathrm{n}^{\circ} 87.561 \text { de } 13 \text { de } \\
\text { setembro de } 1982\end{array}$ & $614.605,00$ & São Paulo & Mata Atlântica \\
\hline 44 & Rebio do Córrego & Dec $n^{\circ} 87.590$ de 20 de & $2.392,00$ & Espírito & Mata Atlântica \\
\hline
\end{tabular}




\begin{tabular}{|c|c|c|c|c|c|}
\hline & do Veado & $\begin{array}{l}\text { setembro de } 1982 \text { / Dec } \\
\mathrm{n}^{\circ} 89.569 \text { de } 23 \text { de abril } \\
\text { de } 1984\end{array}$ & & Santo & \\
\hline 45 & Rebio do Abufari & $\begin{array}{l}\text { Dec } n^{\circ} 87.585 \text { de } 20 \text { de } \\
\text { setembro de } 1982\end{array}$ & $288.000,00$ & Amazonas & Amazônia \\
\hline 46 & Rebio do Guaporé & $\begin{array}{l}\text { Dec } \mathrm{n}^{\circ} 87.587 \text { de } 20 \text { de } \\
\text { setembro de } 1982\end{array}$ & $600.000,00$ & Rondônia & Amazônia \\
\hline 47 & $\begin{array}{l}\text { Rebio de Augusto } \\
\text { Ruschi }\end{array}$ & $\begin{array}{l}\text { Dec no } 87.589 \text { de } 20 \text { de } \\
\text { setembro de } 1982 / \text { Dec } n^{\circ} \\
92.753 \text { de } 05 \text { de junho de } \\
1986\end{array}$ & $4.000,00$ & $\begin{array}{l}\text { Espírito } \\
\text { Santo }\end{array}$ & Mata Atlântica \\
\hline 48 & $\begin{array}{l}\text { Rebio de Serra } \\
\text { Negra }\end{array}$ & $\begin{array}{l}\text { Dec } n^{\circ} 87.591 \text { de } 20 \text { de } \\
\text { setembro de } 1982\end{array}$ & $1.100,00$ & Pernambuco & Caatinga \\
\hline 49 & $\begin{array}{l}\text { Parna Marinho dos } \\
\text { Abrolhos }\end{array}$ & $\begin{array}{l}\text { Dec no } 88.218 \text { de } 06 \text { de } \\
\text { abril de } 1983\end{array}$ & $91.255,00$ & Bahia & $\begin{array}{l}\text { Marinho } \\
\text { Costeiro }\end{array}$ \\
\hline 50 & APA de Piaçabuçú & $\begin{array}{l}\text { Dec } n^{\circ} 88.421 \text { de } 21 \text { de } \\
\text { junho de } 1983\end{array}$ & $9.143,00$ & Alagoas & $\begin{array}{l}\text { Marinho } \\
\text { Costeiro }\end{array}$ \\
\hline 51 & $\begin{array}{l}\text { Esec de Jutaí- } \\
\text { Solimões }\end{array}$ & $\begin{array}{l}\text { Dec } n^{\circ} 88541 \text { de } 21 \text { de } \\
\text { julho de } 1983\end{array}$ & $288.187,37$ & Amazonas & Amazônia \\
\hline 52 & Rebio de Saltinho & $\begin{array}{l}\text { Dec no } 88.744 \text { de } 21 \text { de } \\
\text { setembro de } 1983\end{array}$ & 548,00 & Pernambuco & Mata Atlântica \\
\hline 53 & $\begin{array}{l}\text { APA da Bacia do } \\
\text { Rio Descoberto }\end{array}$ & $\begin{array}{l}\text { Dec } \mathrm{n}^{\circ} 88.940 \text { de } 7 \text { de } \\
\text { novembro de } 1983\end{array}$ & $41.064,00$ & $\begin{array}{l}\text { Distrito } \\
\text { Federal }\end{array}$ & Cerrado \\
\hline 54 & $\begin{array}{l}\text { APA da Bacia do } \\
\text { Rio São } \\
\text { Bartolomeu }\end{array}$ & $\begin{array}{l}\text { Dec } \mathrm{n}^{\circ} 88.940 \text { de } 7 \text { de } \\
\text { novembro de } 1983\end{array}$ & $82.680,00$ & $\begin{array}{l}\text { Distrito } \\
\text { Federal }\end{array}$ & Cerrado \\
\hline 55 & APA de Cairuçu & $\begin{array}{l}\text { Dec } n^{\circ} 89.242 \text { de } 27 \text { de } \\
\text { dezembro de } 1983\end{array}$ & $32.688,00$ & $\begin{array}{l}\text { Rio de } \\
\text { Janeiro }\end{array}$ & $\begin{array}{l}\text { Marinho } \\
\text { Costeiro }\end{array}$ \\
\hline 56 & $\begin{array}{l}\text { Arie Floresta da } \\
\text { Cicuta }\end{array}$ & $\begin{array}{l}\text { Resolução Conama } n^{\circ} 005 \\
\text { de } 05 \text { de junho de } 1984\end{array}$ & 131,00 & $\begin{array}{l}\text { Rio de } \\
\text { Janeiro }\end{array}$ & Mata Atlântica \\
\hline 57 & $\begin{array}{l}\text { Arie Pontal dos } \\
\text { Latinos e Pontal do } \\
\text { Santiago }\end{array}$ & $\begin{array}{l}\text { Resolução Conama } \text { n }^{\circ} 005 \\
\text { de } 05 \text { de junho de } 1984\end{array}$ & 207,00 & $\begin{array}{l}\text { Rio Grande } \\
\text { do Sul }\end{array}$ & Pampa \\
\hline 58 & Arie Corobobó & $\begin{array}{l}\text { Resolução Conama } n^{\circ} 005 \\
\text { de } 05 \text { de junho de } 1984\end{array}$ & $7.473,00$ & Bahia & Caatinga \\
\hline 59 & $\begin{array}{l}\text { Arie } \quad \text { Projeto } \\
\text { Dinâmica } \\
\text { Biológica de } \\
\text { Fragmentos } \\
\text { Florestais }\end{array}$ & $\begin{array}{l}\text { Resolução Conama }{ }^{\circ} 005 \\
\text { de 05 de junho de } \\
\text { 1984/Dec n }{ }^{\circ} 91.884 \text { de } 05 \\
\text { de nov de } 1985\end{array}$ & $3.288,00$ & Amazonas & Amazônia \\
\hline 60 & $\begin{array}{l}\text { Parna da Serra do } \\
\text { Cipó }\end{array}$ & $\begin{array}{l}\text { Dec } n^{\circ} 90.223 \text { de } 25 \text { de } \\
\text { setembro de } 1984 / \text { Dec }^{\text {o }} \\
94.984 \text { de } 30 \text { de setembro } \\
\text { de } 1987\end{array}$ & $33.800,00$ & Minas Gerais & Cerrado \\
\hline 61 & Flona do Jamari & $\begin{array}{l}\text { Dec no } 90.224 \text { de } 25 \text { de } \\
\text { setembro de } 1984\end{array}$ & $215.000,00$ & Rondônia & Amazônia \\
\hline 62 & $\begin{array}{l}\text { APA de Guapi- } \\
\text { mirim }\end{array}$ & $\begin{array}{l}\text { Dec } n^{\circ} 90.225 \text { de } 25 \text { de } \\
\text { setembro de } 1984\end{array}$ & $13.950,00$ & $\begin{array}{l}\text { Rio de } \\
\text { Janeiro }\end{array}$ & $\begin{array}{l}\text { Marinho } \\
\text { Costeiro }\end{array}$ \\
\hline 63 & $\begin{array}{l}\text { Rebio } \\
\text { Comboios }\end{array}$ & $\begin{array}{l}\text { Dec } n^{\circ} 90.222 \text { de } 25 \text { de } \\
\text { setembro de } 1984\end{array}$ & 833,23 & $\begin{array}{l}\text { Espírito } \\
\text { Santo }\end{array}$ & $\begin{array}{l}\text { Marinho } \\
\text { Costeiro }\end{array}$ \\
\hline 64 & $\begin{array}{l}\text { APA de Cananéia- } \\
\text { Iguape-Peruíbe }\end{array}$ & $\begin{array}{lrrr}\text { Dec } \mathrm{n}^{\mathrm{o}} & 90.347 & \mathrm{de} \\
23.10 .1984 / & \text { Dec } & \mathrm{n}^{\text {o }} \\
91.892 \text { de } & 06 & \mathrm{de} \\
\text { novembro de } & 1985 & \end{array}$ & $196.955,00$ & São Paulo & $\begin{array}{l}\text { Marinho } \\
\text { Costeiro }\end{array}$ \\
\hline 65 & $\begin{array}{l}\text { Arie Vale dos } \\
\text { Dinossauros }\end{array}$ & $\begin{array}{l}\text { Resolução CONAMA no } \\
017 \text { de } 18 \text { de dezembro de } \\
1984\end{array}$ & 146,00 & Paraíba & Caatinga \\
\hline 66 & $\begin{array}{l}\text { Arie Matão de } \\
\text { Cosmópolis }\end{array}$ & $\begin{array}{l}\text { Dec no } 90.791 \text { de } 09 \text { de } \\
\text { janeiro de } 1985\end{array}$ & 173,05 & São Paulo & Cerrado \\
\hline
\end{tabular}




\begin{tabular}{|c|c|c|c|c|c|}
\hline 67 & $\begin{array}{ll}\text { APA } & \text { de } \\
\text { Guaraqueçaba } & \end{array}$ & $\begin{array}{l}\text { Dec n }{ }^{\circ} 90.833 \text { de } 31 \text { de } \\
\text { janeiro de } 1985\end{array}$ & $283.014,00$ & Paraná & $\begin{array}{l}\text { Marinho } \\
\text { Costeiro }\end{array}$ \\
\hline 68 & $\begin{array}{l}\text { Arie } \\
\text { Capetinga/Taquara }\end{array}$ & $\begin{array}{l}\text { Dec }^{\circ} 91.303 \text { de } 03 \text { de } \\
\text { junho de } 1985\end{array}$ & $2.100,00$ & $\begin{array}{l}\text { Distrito } \\
\text { Federal }\end{array}$ & Cerrado \\
\hline 69 & $\begin{array}{l}\text { APA da Serra da } \\
\text { Mantiqueira }\end{array}$ & $\begin{array}{l}\text { Dec no } 91.304 \text { de } 03 \text { de } \\
\text { junho de } 1985\end{array}$ & $411.184,00$ & $\begin{array}{l}\text { Minas Gerais } \\
\text { e São Paulo }\end{array}$ & Mata Atlântica \\
\hline 70 & Esec de Niquiá & $\begin{array}{l}\text { Dec } n^{\circ} 91.306 \text { de } 03 \text { de } \\
\text { junho de } 1985\end{array}$ & $286.600,00$ & Roraima & Amazônia \\
\hline 71 & Esec Juami-Japurá & $\begin{array}{l}\text { Dec } n^{\circ} 91307 \text { de } 03 \text { de } \\
\text { junho de } 1985\end{array}$ & $572.650,00$ & Amazonas & Amazônia \\
\hline 72 & $\begin{array}{l}\text { Parna da Chapada } \\
\text { Diamantina }\end{array}$ & $\begin{array}{l}\text { Dec } n^{\circ} 91.655 \text { de } 17 \text { de } \\
\text { setembro de } 1985\end{array}$ & $152.000,00$ & Bahia & Caatinga \\
\hline 73 & $\begin{array}{l}\text { Arie Mata de Santa } \\
\text { Genebra }\end{array}$ & $\begin{array}{l}\text { Dec } \mathrm{n}^{\circ} 91.885 \text { de } 05 \text { de } \\
\text { novembro de } 1985\end{array}$ & 215,77 & São Paulo & Mata Atlântica \\
\hline 74 & Arie Javari Buriti & $\begin{array}{l}\text { Dec } \mathrm{n}^{\circ} 91.886 \text { de } 05 \text { de } \\
\text { novembro de } 1985\end{array}$ & $15.000,00$ & Amazonas & Amazônia \\
\hline 75 & $\begin{array}{l}\text { Arie Ilhas da } \\
\text { Queimada Pequena } \\
\text { e } \quad \text { Queimada } \\
\text { Grande }\end{array}$ & $\begin{array}{l}\text { Dec } \mathrm{n}^{\circ} 91.887 \text { de } 05 \text { de } \\
\text { novembro de } 1985\end{array}$ & 33,00 & São Paulo & $\begin{array}{l}\text { Marinho } \\
\text { Costeiro }\end{array}$ \\
\hline 76 & $\begin{array}{l}\text { Arie Ilha do } \\
\text { Ameixal }\end{array}$ & $\begin{array}{l}\text { Dec } n^{\circ} 91.889 \text { de } 05 \text { de } \\
\text { novembro de } 1985\end{array}$ & 400,00 & São Paulo & $\begin{array}{l}\text { Marinho } \\
\text { Costeiro }\end{array}$ \\
\hline 77 & $\begin{array}{l}\text { Arie Manguezais } \\
\text { da Foz do Rio } \\
\text { Mamanguape }\end{array}$ & $\begin{array}{l}\text { Dec } \mathrm{n}^{\circ} 91.890 \text { de } 05 \text { de } \\
\text { novembro de } 1985\end{array}$ & $5.721,07$ & Paraíba & $\begin{array}{l}\text { Marinho } \\
\text { Costeiro }\end{array}$ \\
\hline
\end{tabular}

Tabela 8 Grupos e categorias de manejo das unidades de conservação propostas em 1989

\begin{tabular}{|c|c|c|c|c|c|}
\hline $\begin{array}{l}\text { GRUPOS DE } \\
\text { PROTEÇÃO }\end{array}$ & CARACTERÍSTICAS & CATEGORIAS & $\begin{array}{l}\text { FINALIDADES } \\
\text { PRECÍPUAS }\end{array}$ & $\begin{array}{c}\text { OCUPAÇÃO } \\
/ \\
\text { VISITAÇÃO }\end{array}$ & $\begin{array}{l}\text { PROPRIE } \\
\text {-DADE }\end{array}$ \\
\hline \multirow[t]{4}{*}{$\begin{array}{l}\text { Unidades } \\
\text { Proteção } \\
\text { Integral }\end{array}$} & $\begin{array}{lr}\text { - proteção integral } \\
\text { dos } & \text { atributos } \\
\text { naturais; } & \end{array}$ & $\begin{array}{l}\text { A-Reserva } \\
\text { Ecológica }\end{array}$ & $\begin{array}{l}\text { Preservação } \\
\text { biológica e } \\
\text { pesquisa } \\
\text { científica }\end{array}$ & $\begin{array}{l}\text { Visitação } \\
\text { não } \\
\text { permitida, } \\
\text { excetuados } \\
\text { casos } \\
\text { especiais }\end{array}$ & Pública \\
\hline & $\begin{array}{l}\text { - somente uso } \\
\text { indireto dos } \\
\text { recursos naturais; } \\
\text { - manutenção dos } \\
\text { ecossistemas em } \\
\text { estado natural, com }\end{array}$ & $\begin{array}{l}\text { B-Parque Nacional, } \\
\text { Parque Estadual, } \\
\text { Parque Natural } \\
\text { Municipal }\end{array}$ & $\begin{array}{l}\text { Preservação } \\
\text { biológica } \\
\text { paisagística } \\
\text { pesquisa } \\
\text { científica } \\
\text { recreação }\end{array}$ & $\begin{array}{l}\text { Visitação } \\
\text { com alta } \\
\text { prioridade, } \\
\text { sob } \\
\text { controle }\end{array}$ & Pública \\
\hline & $\begin{array}{l}\text { o mínimo } \\
\text { indispensável de } \\
\text { alteração. }\end{array}$ & $\begin{array}{l}\text { C-Monumento } \\
\text { Natural }\end{array}$ & $\begin{array}{l}\text { Preservação } \\
\text { de atributos } \\
\text { abióticos e } \\
\text { recreação }\end{array}$ & $\begin{array}{l}\text { Visitação } \\
\text { com alta } \\
\text { prioridade, } \\
\text { sob } \\
\text { controle }\end{array}$ & Pública \\
\hline & & $\begin{array}{l}\text { D-Refúgio de Vida } \\
\text { Silvestre }\end{array}$ & $\begin{array}{l}\text { Proteção de } \\
\text { ecossistemas e } \\
\text { espécies } \\
\text { particulares }\end{array}$ & $\begin{array}{l}\text { Visitação } \\
\text { permitida } \\
\text { em alguns } \\
\text { casos }\end{array}$ & $\begin{array}{l}\text { Pública } \\
\text { e/ou } \\
\text { privada }\end{array}$ \\
\hline $\begin{array}{l}\text { Unidades } \\
\text { Manejo }\end{array}$ & $\begin{array}{l}\text { - proteção total dos } \\
\text { recursos naturais, }\end{array}$ & $\begin{array}{l}\text { E-Reserva de } \\
\text { Recursos Naturais }\end{array}$ & $\begin{array}{l}\text { Preservação } \\
\text { de áreas }\end{array}$ & $\begin{array}{l}\text { Ocupação } \\
\text { por }\end{array}$ & $\begin{array}{l}\text { Pública } \\
\text { e/ou }\end{array}$ \\
\hline
\end{tabular}




\begin{tabular}{|c|c|c|c|c|c|}
\hline Provisório & 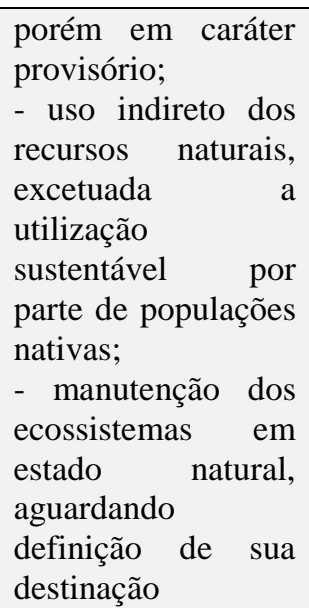 & & $\begin{array}{l}\text { naturais para } \\
\text { uso futuro }\end{array}$ & $\begin{array}{l}\text { população } \\
\text { nativa } \\
\text { possível. } \\
\text { Visitação } \\
\text { não } \\
\text { prevista. }\end{array}$ & privada \\
\hline \multirow[t]{4}{*}{$\begin{array}{l}\text { Unidades de } \\
\text { Manejo } \\
\text { Sustentável }\end{array}$} & & $\begin{array}{l}\text { F-Reserva de } \\
\text { Fauna }\end{array}$ & $\begin{array}{l}\text { Uso } \\
\text { sustentado de } \\
\text { recursos } \\
\text { naturais, } \\
\text { notadamente } \\
\text { fauna silvestre }\end{array}$ & $\begin{array}{l}\text { Visitação } \\
\text { condiciona } \\
\text { da a } \\
\text { finalidade } \\
\text { principal }\end{array}$ & Pública \\
\hline & $\begin{array}{l}\text { - proteção dos } \\
\text { recursos naturais } \\
\text { em grau parcial; e } \\
\text { - uso direto } \\
\text { sustentável de pelo } \\
\text { menos parte dos } \\
\text { recursos }\end{array}$ & $\begin{array}{l}\text { G-Área de Proteção } \\
\text { Ambiental }\end{array}$ & $\begin{array}{l}\text { Usos } \\
\text { múltiplos } \\
\text { condicionados } \\
\text { a proteção de } \\
\text { atributos } \\
\text { bióticos } \\
\text { estéticos e } \\
\text { culturais }\end{array}$ & $\begin{array}{l}\text { Ocupação } \\
\text { humana } \\
\text { controlada }\end{array}$ & $\begin{array}{l}\text { Privada, } \\
\text { privada e } \\
\text { pública, } \\
\text { eventual } \\
\text { mente } \\
\text { pública }\end{array}$ \\
\hline & disponíveis & $\begin{array}{l}\text { H-Floresta } \\
\text { Nacional } \\
\text { Floresta } \\
\text { Estadual } \\
\text { Floresta } \\
\text { Municipal }\end{array}$ & $\begin{array}{l}\text { Extração } \\
\text { sustentável de } \\
\text { madeira } \quad \mathrm{e} \\
\text { outros } \\
\text { produtos } \\
\text { florestais }\end{array}$ & $\begin{array}{l}\text { Visitação } \\
\text { condiciona } \\
\text { da a } \\
\text { finalidade } \\
\text { principal }\end{array}$ & Pública \\
\hline & & $\begin{array}{l}\text { I-Reserva } \\
\text { Extrativista }\end{array}$ & $\begin{array}{l}\text { Extração } \\
\text { sustentável de } \\
\text { produtos } \\
\text { florestais, } \\
\text { exceto } \\
\text { madeira. }\end{array}$ & $\begin{array}{l}\text { Ocupação } \\
\text { por grupos } \\
\text { sociais } \\
\text { tradicionai } \\
\text { s. Visitação } \\
\text { não } \\
\text { prevista. }\end{array}$ & Pública \\
\hline
\end{tabular}

Fonte: FUNATURA, 1989.

Tabela 9 Categorias de Unidades de Conservação segundo o SNUC (2000)

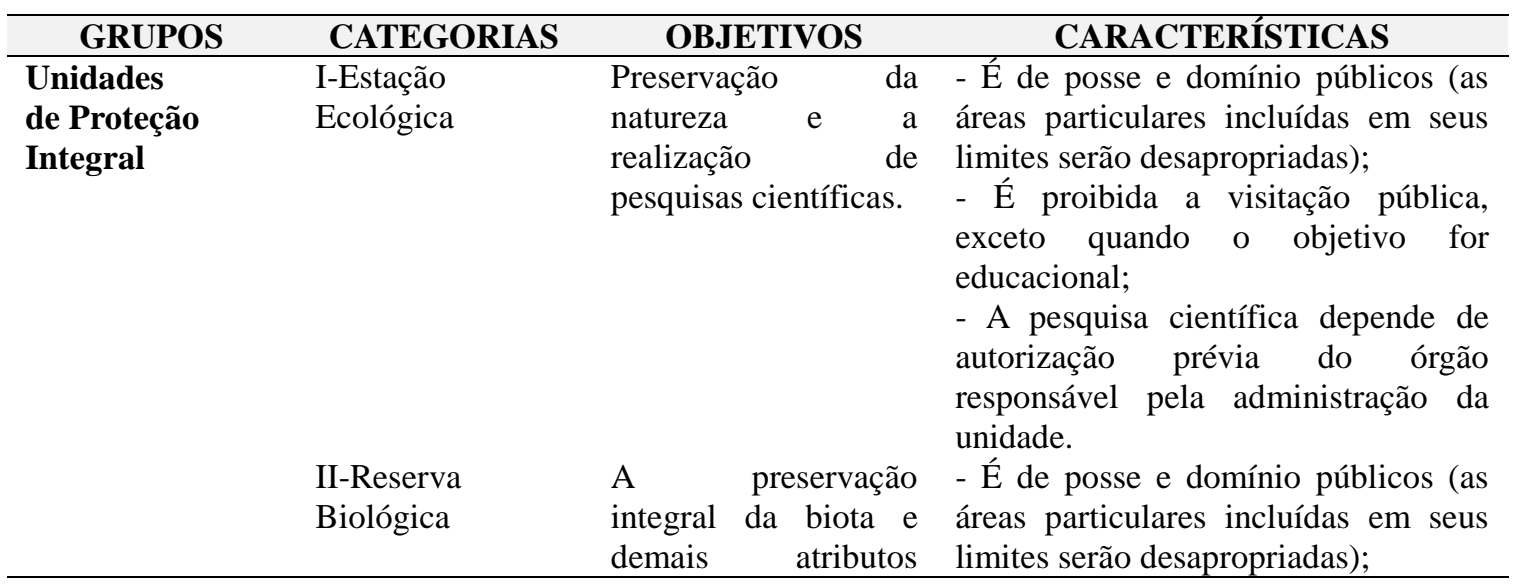


III-Parque Nacional

IV-Monumento Natural

V-Refúgio Vida Silvestre naturais existentes em seus limites, sem interferência humana direta modificações ambientais, excetuando-se medidas recuperação de seus ecossistemas alterados e as ações de manejo necessárias para recuperar e preservar o equilíbrio natural, a diversidade biológica e os processos ecológicos naturais.

A preservação de ecossistemas naturais de grande relevância ecológica e beleza cênica, possibilitando a realização de pesquisas científicas e o desenvolvimento de atividades de educação interpretação ambiental, recreação em contato com a natureza e de turismo ecológico.

\section{Preservar naturais singulares ou de grande beleza cênica.}

- É proibida a visitação pública, exceto quando o objetivo for educacional;

ou - A pesquisa científica depende de autorização prévia do órgão responsável pela administração da unidade.

- É de posse e domínio públicos (as áreas particulares incluídas em seus limites serão desapropriadas);

-A visitação pública está sujeita às normas e restrições estabelecidas no Plano de Manejo da unidade, às normas estabelecidas pelo órgão responsável por sua administração, e àquelas previstas em regulamento;

- A pesquisa científica depende de autorização prévia do órgão responsável pela administração da unidade;

-As unidades dessa categoria, quando criadas pelo Estado ou Município, serão denominadas, respectivamente, Parque Estadual e Parque Natural Municipal.

- Pode ser constituído por áreas particulares, desde que seja possível compatibilizar os objetivos da unidade com a utilização da terra e dos recursos naturais do local pelos proprietários;

-A visitação pública está sujeita às normas e restrições estabelecidas no Plano de Manejo da unidade, às normas estabelecidas pelo órgão responsável por sua administração, e àquelas previstas em regulamento.

-Pode ser constituído por áreas particulares, desde que seja possível compatibilizar os objetivos da unidade com a utilização da terra e dos recursos naturais do local pelos proprietários;

-A visitação pública está sujeita às normas e restrições estabelecidas no Plano de Manejo da unidade, às normas estabelecidas pelo órgão responsável por sua administração, e 


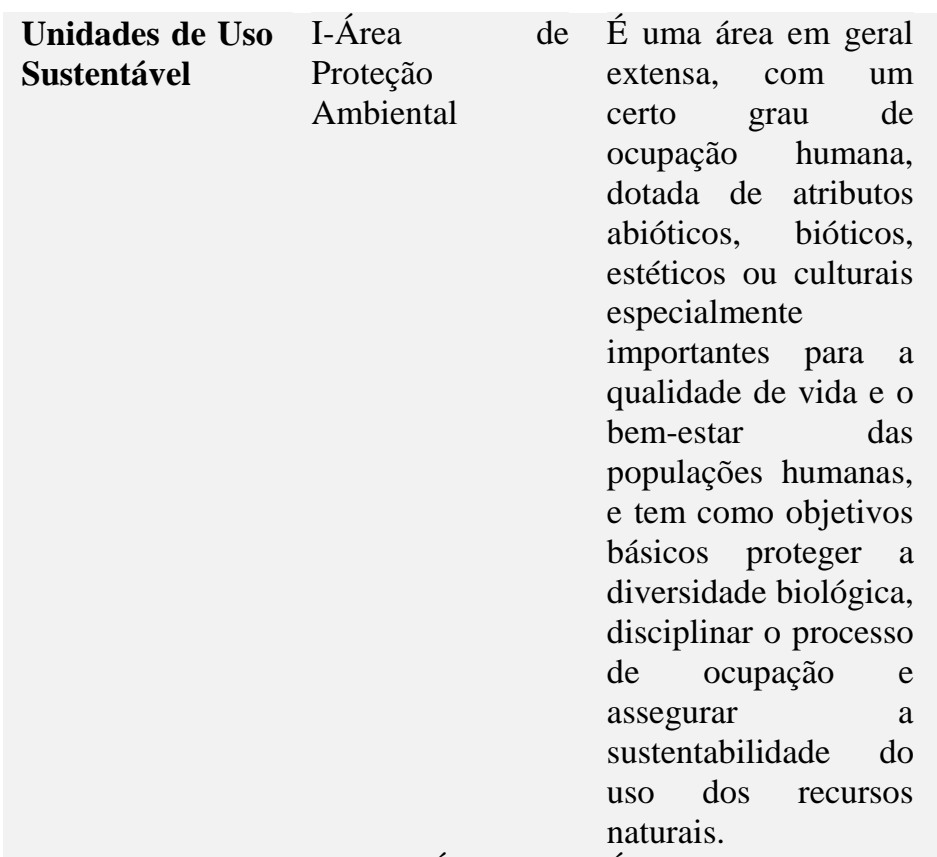

II - Área de É uma área em geral Relevante de pequena extensão, Interesse Ecológico

III - Floresta

Nacional com pouca ou nenhuma ocupação humana, com características

naturais

extraordinárias ou que abriga exemplares raros da biota regional, e tem como objetivo manter os ecossistemas naturais de importância regional ou local e regular o uso admissível dessas áreas, de modo a compatibilizá-lo com os objetivos de conservação da natureza.

A Floresta Nacional é uma área com cobertura florestal de espécies

predominantemente nativas e tem como objetivo básico o uso múltiplo sustentável dos recursos florestais e a pesquisa científica, com ênfase em métodos para àquelas previstas em regulamento;

- A pesquisa científica depende de autorização prévia do órgão responsável pela administração da unidade;

-É constituída por terras públicas ou privadas;

-Respeitados os limites constitucionais, podem ser estabelecidas normas e restrições para a utilização de uma propriedade privada localizada em uma dentro da área;

-A pesquisa científica e a visitação pública nas áreas sob domínio público serão estabelecidas pelo órgão gestor da unidade;

-Nas áreas sob propriedade privada, cabe ao proprietário estabelecer as condições para pesquisa e visitação pelo público, observadas as exigências e restrições legais

-É constituída por terras públicas ou privadas;

-Respeitados os limites constitucionais, podem ser estabelecidas normas e restrições para a utilização de uma propriedade privada localizada em uma dentro da área;

-É de posse e domínio públicos, sendo que as áreas particulares incluídas em seus limites devem ser desapropriadas;

-É admitida a permanência de populações tradicionais que a habitam quando de sua criação, em conformidade com o disposto em regulamento e no Plano de Manejo da unidade;

-A visitação pública é permitida, condicionada às normas estabelecidas 
exploração

sustentável

florestas nativas.

IV-Reserva

Extrativista

V-Reserva

Fauna

VI-Reserva de Desenvolvimento Sustentável populações
É uma área utilizada por populações extrativistas tradicionais, cuja subsistência baseia-se no extrativismo e, complementarmente, na agricultura de subsistência e na criação de animais de pequeno porte, e tem como objetivos básicos proteger os meios de vida e a cultura dessas populações, e assegurar o uso sustentável dos recursos naturais da unidade. para o manejo da unidade pelo órgão de por sua administração -A pesquisa é permitida e incentivada, sujeitando-se à prévia autorização do órgão responsável pela administração da unidade;

-A unidade desta categoria, quando criada pelo Estado ou Município, será denominada, respectivamente, Floresta Estadual e Floresta Municipal.

-É de domínio público, com uso concedido às populações extrativistas tradicionais (as áreas particulares incluídas em seus limites devem ser desapropriadas);

-A visitação pública é permitida, desde que compatível com os interesses locais e de acordo com o disposto no Plano de Manejo da área; -A pesquisa científica é permitida e incentivada, sujeitando-se à prévia autorização do órgão responsável pela administração da unidade;

-São proibidas a exploração de recursos minerais e a caça amadorística ou profissional;

-A exploração comercial de recursos madeireiros só será admitida em bases sustentáveis e em situações especiais e complementares às demais atividades desenvolvidas na Reserva Extrativista, conforme o disposto em regulamento e no Plano de Manejo da unidade;

-É de posse e domínio públicos (as áreas particulares incluídas em seus limites devem ser desapropriadas);

-A visitação pública pode ser permitida, desde que compatível com o manejo da unidade e de acordo com as normas estabelecidas pelo órgão responsável por sua administração;

-É proibido o exercício da caça amadorística ou profissional;

-A comercialização dos produtos e subprodutos resultantes das pesquisas obedecerá ao disposto nas leis sobre fauna e regulamentos.

-É permitida e incentivada a visitação pública, desde que compatível com os interesses locais e de acordo com o abriga tradicionais, cuja existência baseia-se em sistemas sustentáveis de exploração dos recursos naturais, desenvolvidos ao -É permitida e incentivada a pesquisa científica voltada à conservação da natureza, à melhor relação das populações residentes com seu meio e à educação ambiental, sujeitando-se à prévia autorização do órgão disposto no Plano de Manejo da área; 


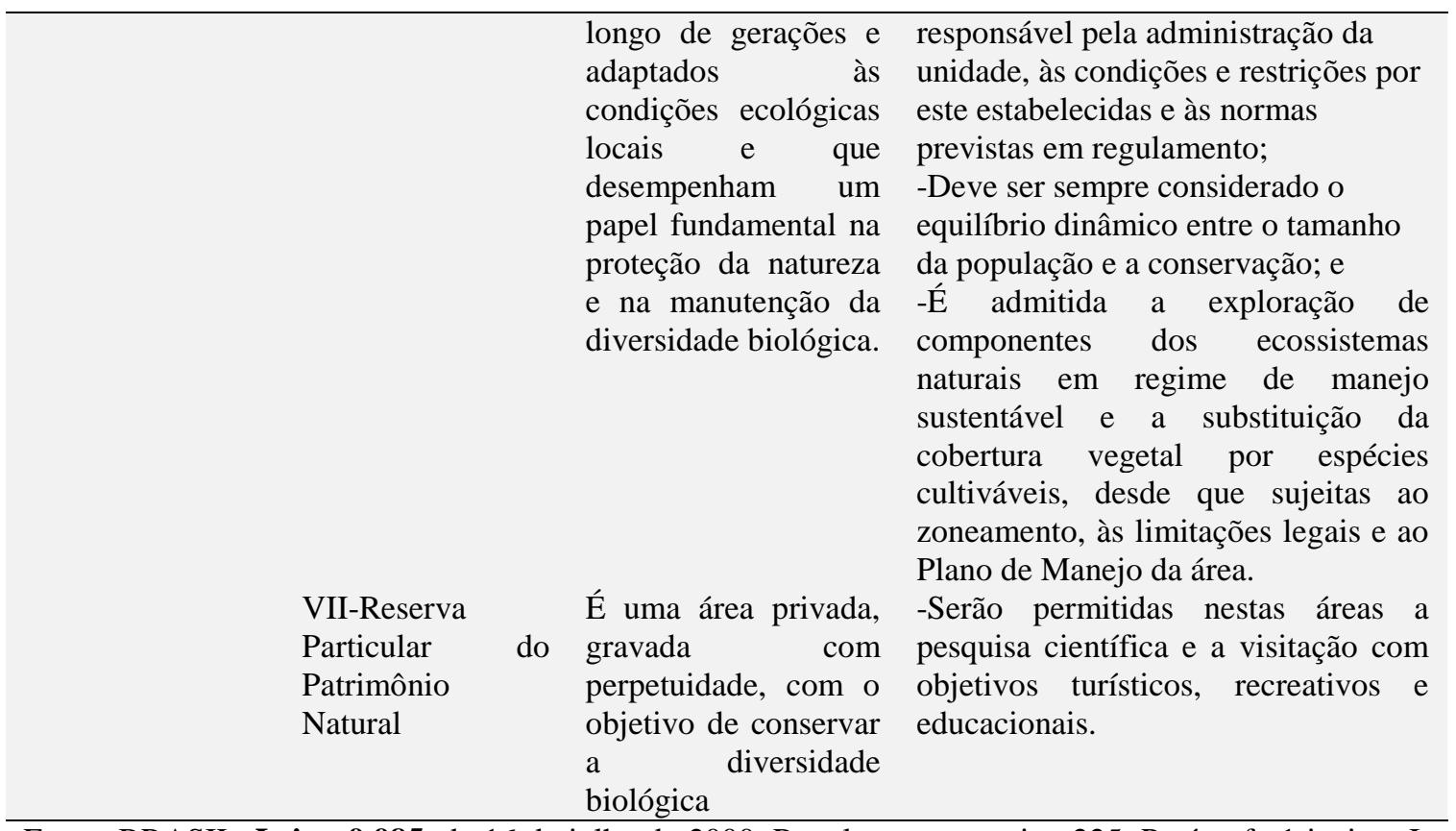

Fonte: BRASIL. Lei n. 9.985, de 16 de julho de 2000. Regulamenta o artigo 225, Parágrafo 1 incisos I, II, III e VII da Constituição Federal, institui o Sistema Nacional de Unidades de Conservação da Natureza e dá outras providências. Brasília: 2000.

Tabela 10 Evolução das Unidades de Conservação: 1986 a 2000

\begin{tabular}{|c|c|c|c|c|c|}
\hline $\mathbf{N}^{0}$ & NOME & CRIAÇÃO & ÁREA/Ha & ESTADO(S) & BIOMA \\
\hline$\overline{01}$ & $\begin{array}{l}\text { APA de Fernando de } \\
\text { Noronha }\end{array}$ & $\begin{array}{l}\text { Dec } n^{\circ} 92.755 \text { de } 05 \text { de } \\
\text { junho de } 1986\end{array}$ & $93.000,00$ & Pernambuco & $\begin{array}{l}\text { Marinho } \\
\text { Costeiro }\end{array}$ \\
\hline 02 & Esec do Taim & $\begin{array}{l}\text { Dec } n^{\circ} 92.963 \text { de } 21 \text { de } \\
\text { julho de } 1986\end{array}$ & $10.764,63$ & $\begin{array}{c}\text { Rio Grande do } \\
\text { Sul }\end{array}$ & $\begin{array}{l}\text { Marinho } \\
\text { Costeiro }\end{array}$ \\
\hline 03 & Esec de Tupiniquins & $\begin{array}{l}\text { Dec } \mathrm{n}^{\circ} 92.964 \text { de } 21 \text { de } \\
\text { julho de } 1986\end{array}$ & 43,00 & São Paulo & $\begin{array}{l}\text { Marinho } \\
\text { Costeiro }\end{array}$ \\
\hline 04 & Flona Mapiá-Inauini & $\begin{array}{l}\text { Dec } \mathrm{n}^{\circ} 98.051 \text {, de } 14 \text { de } \\
\text { Agosto de } 1986\end{array}$ & $311.000,00$ & Amazonas & Amazônia \\
\hline 05 & Flona Mario Xavier & $\begin{array}{l}\text { Dec } n^{\circ} 93.369 \text { de } 08 \text { de } \\
\text { outubro de } 1986\end{array}$ & 493,00 & Rio de Janeiro & Mata Atlântica \\
\hline 06 & $\begin{array}{l}\text { Parna da Lagoa do } \\
\text { Peixe }\end{array}$ & $\begin{array}{l}\text { Dec } \mathrm{n}^{\circ} 93.546 \text { de } 06 \text { de } \\
\text { novembro de } 1986\end{array}$ & $34.400,00$ & $\begin{array}{c}\text { Rio Grande do } \\
\text { Sul }\end{array}$ & $\begin{array}{l}\text { Marinho } \\
\text { Costeiro }\end{array}$ \\
\hline 07 & Esec de Pirapitinga & $\begin{array}{l}\text { Dec no } 94.656 \text { de } 20 \text { de } \\
\text { julho de } 1987\end{array}$ & 1090,00 & Minas Gerais & Cerrado \\
\hline 08 & Esec de Carijós & $\begin{array}{l}\text { Dec } n^{\circ} 94.656 \text { de } 20 \text { de } \\
\text { julho de } 1987\end{array}$ & 618,70 & Santa Catarina & $\begin{array}{l}\text { Marinho } \\
\text { Costeiro }\end{array}$ \\
\hline 09 & Esec de Tupinambás & $\begin{array}{l}\text { Dec } n^{\circ} 94.656 \text { de } 20 \text { de } \\
\text { julho de } 1987\end{array}$ & $1.090,00$ & São Paulo & $\begin{array}{l}\text { Marinho } \\
\text { Costeiro }\end{array}$ \\
\hline 10 & Rebio do Gurupi & $\begin{array}{l}\text { Dec } n^{\circ} 95.614 \text { de } 12 \text { de } \\
\text { janeiro de } 1988\end{array}$ & $341.650,00$ & Maranhão & Amazônia \\
\hline 11 & Flona de Ibirama & $\begin{array}{l}\text { Dec } n^{\circ} 95.818 \text { de } 11 \text { de } \\
\text { março de } 1988\end{array}$ & 570,58 & Santa Catarina & Mata Atlântica \\
\hline 12 & Flona Bom Futuro & $\begin{array}{l}\text { Dec } n^{\circ} 96.188 \text { de } 21 \text { de } \\
\text { junho de } 1988 / \text { Lei } n^{\circ} \\
12.249 \text { de } 11 \text { de junho de } \\
2010\end{array}$ & $280.000,00$ & Rondônia & Amazônia \\
\hline 13 & Flona do Macauã & $\begin{array}{l}\text { Dec } n^{\circ} 96.189 \text { de } 21 \text { de } \\
\text { junho de } 1988\end{array}$ & $173.475,00$ & Acre & Amazônia \\
\hline 14 & Flona do Purus & $\begin{array}{l}\text { Dec } n^{\circ} 96.190 \text { de } 21 \text { de } \\
\text { junho de } 1988\end{array}$ & $256.000,00$ & Amazonas & Amazônia \\
\hline
\end{tabular}


15 Parna Marinho de Dec no 96.693 de 14 de Fernando de Noronha

16 Rebio de Santa Isabel

17 Flona de Roraima

18 Flona do Amazonas

19 Flona de Tefé

20 Flona do Amapá

21 Parna da Chapada dos Guimarães

22 Rebio do Córrego Grande

23 Parna Grande Sertão Veredas

24 Parna do Superagui

25 APA do Igarapé Gelado

26 Rebio do Tapirapé

27 Flona do Tapirape-aquiri

28 Rebio do Tinguá

29 Parna da Serra do Divisor

30 Parna do Monte Roraima

31 APA Cavernas do Peruaçu

32 Rebio de Pedra Talhada

33 Flona de Saracá-Taquera

34 Flona do Rio Preto

35 Resex Alto Juruá

36 Esec de Tamoios

37 APA do Carste de Lagoa Santa

38 Rebio Guaribas

39 APA do Morro da Pedreira

40 Rebio Marinha do Arvoredo

41 Resex Chico Mendes

42 Resex Rio Cajari setembro de 1988

Dec $n^{\circ} 96.999$ de 20 de outubro de 1988

Dec $\mathrm{n}^{\circ} 97545$ de $1^{\circ}$ de março de 1989

Dec $n^{\circ} 97.546$ de $1^{\circ}$ de março de 1989

Dec $\mathrm{n}^{\circ} 97.629$ de 10 de abril de 1989

Dec n ${ }^{\circ} 97.630$ de 10 de abril de 1989

Dec $\mathrm{n}^{\circ} 97.656$ de 12 de abril de 1989

Dec $n^{\circ} 97.657$ de 12 de abril de 1989

Dec no 97.658 de 12 de abril de 1989 abril de 1989/Dec $n^{\circ}$ 9.513 de 20 de novembro de 1997

Dec $n^{\circ} 97.718$ de 05 de maio de 1989

Dec $n^{\circ} 97.719$ de 05 de maio de 1989

Dec $n^{\circ} 97.720$ de 05 de maio de 1989

Dec $n^{\circ} 97.780$ de 23 de maio de 1989

Dec $n^{\circ} 97.839$ de 16 de junho de 1989

Dec $n^{\circ} 97.887$ de 28 de junho de 1989

Dec $n^{\circ} 98.182$ de 26 de setembro de 1989

Dec $n^{\circ} 98.524$ de 13 de dezembro de 1989

Dec no 98.704 de 27 de dezembro de 1989

Dec no 98.845 de 17 de janeiro de 1990

Dec no 98.863 de 23 de janeiro de 1990

Dec n ${ }^{\circ} 98.864$ de 23 de janeiro de 1990

Dec no 98.881 de 25 de janeiro de 1990/Dec N ${ }^{\circ}$ 1.876 , de 25 de abril de 1996

Dec no 98.884 de 25 de janeiro de 1990

Dec no 98.891 de 26 de janeiro de 1990

Dec n ${ }^{\circ} 99.142$ de 12 de março de 1990

Dec $^{\circ} 99.144$ de 12 de março de 1990

Dec no 99.145 de 12 de março de 1990
Dec $n^{\circ} 97.688$ de 25 de

\begin{tabular}{|c|c|c|}
\hline $11.270,00$ & Pernambuco & $\begin{array}{l}\text { Marinho } \\
\text { Costeiro }\end{array}$ \\
\hline $2.766,00$ & Sergipe & $\begin{array}{l}\text { Marinho } \\
\text { Costeiro }\end{array}$ \\
\hline $2.664 .685,00$ & Roraima & Amazônia \\
\hline $1.573 .100,00$ & Amazonas & Amazônia \\
\hline $1.020 .000,00$ & Amazonas & Amazônia \\
\hline $412.000,00$ & Amapá & Amazônia \\
\hline 33000,00 & Mato Grosso & Cerrado \\
\hline $1.504,80$ & Espírito Santo & Mata Atlântica \\
\hline $84.000,00$ & $\begin{array}{c}\text { Bahia e Minas } \\
\text { Gerais }\end{array}$ & Cerrado \\
\hline $33.988,00$ & Paraná & $\begin{array}{l}\text { Marinho } \\
\text { Costeiro }\end{array}$ \\
\hline
\end{tabular}

$\begin{array}{rll}21.600,00 & \text { Pará } & \text { Amazônia } \\ 103.000,00 & \text { Pará } & \text { Amazônia } \\ 190.000,00 & \text { Pará } & \text { Amazônia }\end{array}$

24.902,00 Rio de Janeiro Mata Atlântica

846.633,00 Acre Amazônia

116.000,00 Roraima Amazônia

143.866,00 Minas Gerais Cerrado

4.469,00 Alagoas e Mata Atlântica Pernambuco

429.600,00 Pará Amazônia

2.830,63 Espírito Santo Mata Atlântica

\begin{tabular}{|c|c|c|}
\hline $506.186,00$ & Acre & Amazônia \\
\hline 700,00 & Rio de Janeiro & $\begin{array}{l}\text { Marinho } \\
\text { Costeiro }\end{array}$ \\
\hline $35.600,00$ & Minas Gerais & Cerrado \\
\hline
\end{tabular}

$\begin{array}{rcc}100.431,00 & \text { Minas Gerais } & \text { Cerrado } \\ 17.600,00 & \text { Santa Catarina } & \begin{array}{l}\text { Marinho } \\ \text { Costeiro } \\ \text { Amazônia }\end{array} \\ 481.670,00 & \text { Acre } & \text { Amazônia }\end{array}$

481.650,00 Amapá Amazônia 


\begin{tabular}{|c|c|c|c|c|c|}
\hline 43 & Resex Rio Ouro Preto & $\begin{array}{l}\text { Dec } n^{\circ} 99.166 \text { de } 13 \text { de } \\
\text { março de } 1990\end{array}$ & $204.583,00$ & Rondônia & Amazônia \\
\hline 44 & $\begin{array}{l}\text { Arie Cerrado Pé-de- } \\
\text { Gigante }\end{array}$ & $\begin{array}{l}\text { Dec } n^{\circ} 99.275 \text { de } 06 \text { de } \\
\text { junho de } 1990\end{array}$ & $1.060,01$ & São Paulo & Mata Atlântica \\
\hline 45 & $\begin{array}{l}\text { Arie Buriti de } \\
\text { Vassununga }\end{array}$ & $\begin{array}{l}\text { Dec no } 99.276 \text { de } 06 \text { de } \\
\text { junho de } 1990\end{array}$ & 149,87 & São Paulo & Mata Atlântica \\
\hline 46 & Rebio do Uatumã & $\begin{array}{l}\text { Dec n } n^{\circ} 99.277 \text { de } 06 \text { de } \\
\text { junho de } 1990\end{array}$ & $560.000,00$ & Amazonas & Amazônia \\
\hline 47 & $\begin{array}{l}\text { APA da Serra de } \\
\text { Tabatinga }\end{array}$ & $\begin{array}{l}\text { Dec no } 99.278 \text { de } 06 \text { de } \\
\text { junho de } 1990\end{array}$ & $61.000,00$ & $\begin{array}{l}\text { Maranhão e } \\
\text { Tocantins }\end{array}$ & Cerrado \\
\hline 48 & Arie Serra da Abelha & $\begin{array}{l}\text { Resolução CONAMA no } \\
005 \text { de } 17 \text { de outubro de } \\
1990\end{array}$ & $4.234,71$ & Santa Catarina & Mata Atlântica \\
\hline 49 & APA de Anhatomirim & $\begin{array}{l}\text { Dec n }{ }^{\circ} 528 \text { de } 20 \text { de maio } \\
\text { de } 1992\end{array}$ & $3.000,00$ & Santa Catarina & $\begin{array}{l}\text { Marinho } \\
\text { Costeiro }\end{array}$ \\
\hline 50 & APA de Ibirapuitã & $\begin{array}{l}\text { Dec } n^{\circ} 529 \text { de } 20 \text { de maio } \\
\text { de } 1992\end{array}$ & $318.000,00$ & $\begin{array}{l}\text { Rio Grande do } \\
\text { Sul }\end{array}$ & Pampa \\
\hline 51 & Flona de Ipanema & $\begin{array}{l}\text { Dec } \mathrm{n}^{\circ} 530 \text { de } 20 \text { de maio } \\
\text { de } 1992\end{array}$ & $5.179,93$ & São Paulo & Mata Atlântica \\
\hline 52 & Parna de Serra Geral & $\begin{array}{l}\text { Dec } n^{\circ} 531 \text { de } 20 \text { de maio } \\
\text { de } 1992\end{array}$ & $17.300,00$ & $\begin{array}{l}\text { Rio Grande do } \\
\text { Sul e Santa } \\
\text { Catarina }\end{array}$ & Mata Atlântica \\
\hline 53 & Resex Mata Grande & $\begin{array}{l}\text { Dec } \mathrm{n}^{\circ} 532 \text { de } 20 \text { de maio } \\
\text { de } 1992\end{array}$ & $10.450,00$ & Maranhão & Cerrado \\
\hline 54 & $\begin{array}{l}\text { Resex Marinha } \\
\text { Pirajubaé }\end{array}$ & $\begin{array}{l}\text { Dec no }^{\circ} 533 \text { de } 20 \text { de maio } \\
\text { de } 1992\end{array}$ & $1.444,00$ & Santa Catarina & $\begin{array}{l}\text { Marinho } \\
\text { Costeiro }\end{array}$ \\
\hline 55 & $\begin{array}{l}\text { Resex Extremo Norte do } \\
\text { Estado do Tocantins }\end{array}$ & $\begin{array}{l}\text { Dec n }{ }^{\circ} 535 \text { de } 20 \text { de maio } \\
\text { de } 1992\end{array}$ & $9.280,00$ & Tocantins & Cerrado \\
\hline 56 & $\begin{array}{l}\text { Resex Quilombo do } \\
\text { Frechal }\end{array}$ & $\begin{array}{l}\text { Dec n }{ }^{\circ} 536 \text { de } 20 \text { de maio } \\
\text { de } 1992\end{array}$ & $9.542,00$ & Maranhão & Amazônia \\
\hline 57 & $\begin{array}{l}\text { APA da Barra do } \\
\text { Mamanguape }\end{array}$ & $\begin{array}{l}\text { Dec } n^{\circ} 924 \text { de } 10 \text { de } \\
\text { setembro de } 1993\end{array}$ & $14.640,00$ & Paraíba & $\begin{array}{l}\text { Marinho } \\
\text { Costeiro }\end{array}$ \\
\hline 58 & APA Delta do Parnaíba & $\begin{array}{l}\text { Dec s/n. }{ }^{\circ} \text { de } 28 \text { de agosto } \\
\text { de } 1996\end{array}$ & $313.800,00$ & $\begin{array}{l}\text { Piauí, } \\
\text { Maranhão e } \\
\text { Ceará }\end{array}$ & $\begin{array}{l}\text { Marinho } \\
\text { Costeiro }\end{array}$ \\
\hline 59 & APA Serra da Ibiapaba & $\begin{array}{l}\text { Dec s } / \text { n. }^{\circ} \text { de } 26 \text { de } \\
\text { novembro de } 1996\end{array}$ & $1.592 .550,00$ & Piauí e Ceará & Caatinga \\
\hline 60 & $\begin{array}{l}\text { Resex Marinha Arraial } \\
\text { do Cabo }\end{array}$ & $\begin{array}{l}\text { Dec } s / n^{\circ} \text { de } 03 \text { de janeiro } \\
\text { de } 1997\end{array}$ & $56.769,00$ & Rio de Janeiro & $\begin{array}{l}\text { Marinho } \\
\text { Costeiro }\end{array}$ \\
\hline 61 & Resex Médio Juruá & $\begin{array}{l}\text { Dec s/no de } 04 \text { de março } \\
\text { de } 1997\end{array}$ & $253.226,50$ & Amazonas & Amazônia \\
\hline 62 & $\begin{array}{l}\text { APA da Chapada do } \\
\text { Araripe }\end{array}$ & $\begin{array}{l}\text { Dec no de } 04 \text { de agosto de } \\
1997\end{array}$ & $1.063 .000,00$ & $\begin{array}{l}\text { Ceará, } \\
\text { Pernambuco e } \\
\text { Piauí }\end{array}$ & Caatinga \\
\hline 63 & Parna de Ilha Grande & $\begin{array}{l}\text { Dec } s / n^{\circ} \text { de } 30 \text { de } \\
\text { setembro de } 1997\end{array}$ & $78.875,00$ & $\begin{array}{l}\text { Paraná e Mato } \\
\text { Grosso do Sul }\end{array}$ & Mata Atlântica \\
\hline 64 & $\begin{array}{l}\text { APA Ilhas e Várzeas do } \\
\text { Rio Paraná }\end{array}$ & $\begin{array}{l}\text { Dec s/n. }{ }^{\circ} \text { de } 30 \text { de } \\
\text { setembro de } 1997\end{array}$ & $1.003 .059,00$ & $\begin{array}{l}\text { Paraná e Mato } \\
\text { Grosso do Sul }\end{array}$ & Mata Atlântica \\
\hline 65 & $\begin{array}{l}\text { APA da Costa dos } \\
\text { Corais }\end{array}$ & $\begin{array}{l}\text { Dec } n^{\circ} \text { de } 23 \text { de outubro } \\
\text { de } 1997\end{array}$ & $413.563,00$ & $\begin{array}{l}\text { Alagoas e } \\
\text { Pernambuco }\end{array}$ & $\begin{array}{l}\text { Marinho } \\
\text { Costeiro }\end{array}$ \\
\hline 66 & Flona do Itacaiunas & $\begin{array}{l}\operatorname{Dec}^{\circ} 2.480 \text { de } 02 \text { de } \\
\text { fevereiro de } 1998\end{array}$ & $141.400,00$ & Pará & Amazônia \\
\hline 67 & Flona de Itaituba 1 & $\begin{array}{l}\operatorname{Dec}^{\circ} 2.481 \text { de } 02 \text { de } \\
\text { fevereiro de } 1998\end{array}$ & $220.034,20$ & Pará & Amazônia \\
\hline 68 & Flona de Itaituba 2 & $\begin{array}{l}\operatorname{Dec}^{\circ} 2.482 \text { de } 02 \text { de } \\
\text { fevereiro de } 1998\end{array}$ & $440.500,00$ & Pará & Amazônia \\
\hline 69 & Flona Altamira & $\begin{array}{l}\text { Dec n }{ }^{\circ} 2.483 \text { de } 02 \text { de } \\
\text { fevereiro de } 1998\end{array}$ & $689.012,00$ & Pará & Amazônia \\
\hline 70 & Flona de Humaitá & $\begin{array}{l}\operatorname{Dec}^{\circ} 2.485 \text { de } 02 \text { de } \\
\text { fevereiro de } 1998\end{array}$ & $468.790,00$ & Amazonas & Amazônia \\
\hline
\end{tabular}




\begin{tabular}{|c|c|c|c|c|c|}
\hline 71 & Flona de Carajás & $\begin{array}{l}\text { Dec }^{\circ} 2.486 \text { de } 02 \text { de } \\
\text { fevereiro de } 1998\end{array}$ & $411.948,87$ & Pará & Amazônia \\
\hline 72 & Rebio União & $\begin{array}{l}\text { Decreto } s / n^{\circ} \text { de } 22 \text { de abril } \\
\text { de } 1998\end{array}$ & $2.930,00$ & Rio de Janeiro & Mata Atlântica \\
\hline 73 & $\begin{array}{l}\text { Parna da Restinga de } \\
\text { Jurubatiba }\end{array}$ & $\begin{array}{l}\text { Dec } s / n^{\circ} \text { de } 29 \text { de abril de } \\
1998\end{array}$ & $14.860,00$ & Rio de Janeiro & $\begin{array}{l}\text { Marinho } \\
\text { Costeiro }\end{array}$ \\
\hline 74 & $\begin{array}{l}\text { Parna da Serra da } \\
\text { Mocidade }\end{array}$ & $\begin{array}{l}\text { Dec s/no de } 29 \text { de abril d e } \\
1998\end{array}$ & $350.960,45$ & Roraima & Amazônia \\
\hline 75 & Parna do Viruá & $\begin{array}{l}\text { Dec } s / n^{\circ} \text { de } 29 \text { de abril de } \\
1998\end{array}$ & $227.011,00$ & Roraima & Amazônia \\
\hline 76 & $\begin{array}{l}\text { Parna da Serra das } \\
\text { Confusões }\end{array}$ & $\begin{array}{l}\text { Dec } s / n^{\circ} \text { de } 02 \text { de outubro } \\
\text { de } 1998\end{array}$ & $502.411,00$ & Piauí & Caatinga \\
\hline 77 & $\begin{array}{l}\text { APA Meandros do Rio } \\
\text { Araguaia }\end{array}$ & $\begin{array}{l}\text { Decreto } 02 \text { de Outubro de } \\
1998\end{array}$ & $357.126,00$ & $\begin{array}{c}\text { Goiás, Mato } \\
\text { Grosso e } \\
\text { Tocantins }\end{array}$ & Cerrado \\
\hline 78 & Resex Tapajós-Arapiuns & $\begin{array}{l}\text { Dec } s / n^{\circ} \text { de } 06 \text { de } \\
\text { novembro de } 1998\end{array}$ & $647.610,74$ & Pará & Amazônia \\
\hline 79 & Parna do Pau Brasil & $\begin{array}{l}\text { Dec } s / n^{\circ} \text { de } 20 \text { de abril de } \\
1999\end{array}$ & $11.038,00$ & Bahia & Mata Atlântica \\
\hline 80 & Parna do Descobrimento & $\begin{array}{l}\text { Dec s/no de } 20 \text { de abril de } \\
1999\end{array}$ & $21.129,00$ & Bahia & Mata Atlântica \\
\hline 81 & Flona de Brasília & $\begin{array}{l}\text { Dec } s / n^{\circ} \text { de } 10 \text { de junho } \\
\text { de } 1999\end{array}$ & $9.346,28$ & $\begin{array}{l}\text { Distrito } \\
\text { Federal }\end{array}$ & Cerrado \\
\hline 82 & $\begin{array}{l}\text { Arie Seringal Nova } \\
\text { Esperança }\end{array}$ & $\begin{array}{l}\text { Dec } s / n^{\circ} \text { de } 20 \text { de agosto } \\
\text { de } 1999\end{array}$ & $2.576,47$ & Acre & Amazônia \\
\hline 83 & Flona de Ritapolis & $\begin{array}{l}\text { Dec } s / n^{\circ} \text { de } 21 \text { de } \\
\text { setembro de } 1999\end{array}$ & 89,50 & Minas Gerais & Mata Atlântica \\
\hline 84 & $\begin{array}{l}\text { Flona Contendas do } \\
\text { Sincorá }\end{array}$ & $\begin{array}{l}\text { Dec } s / n^{\circ} \text { de } 21 \text { de } \\
\text { setembro de } 1999\end{array}$ & $11.034,00$ & Bahia & Caatinga \\
\hline 85 & $\begin{array}{l}\text { Parna Cavernas do } \\
\text { Peruaçu }\end{array}$ & $\begin{array}{l}\text { Dec } s / n^{\circ} \text { de } 21 \text { de } \\
\text { setembro de } 1999\end{array}$ & $56.800,00$ & Minas Gerais & Cerrado \\
\hline 86 & Resex Lago do Cuniã & $\begin{array}{l}\text { Dec n } 3.238 \text { de } 10 \text { de } \\
\text { novembro de } 1999\end{array}$ & $55.850,00$ & Rondônia & Amazônia \\
\hline 87 & $\begin{array}{l}\text { Resex Marinha da Baia } \\
\text { de Iguape }\end{array}$ & $\begin{array}{l}\text { Dec } s / n^{\circ} \text { de } 11 \text { de agosto } \\
\text { de } 2000\end{array}$ & $8.117,53$ & Bahia & Mata Atlântica \\
\hline 88 & APA da Baleia Franca & $\begin{array}{l}\text { Dec } \mathrm{n}^{\circ} \text { de } 14 \text { de setembro } \\
\text { de } 2000\end{array}$ & $156.100,00$ & Santa Catarina & $\begin{array}{l}\text { Marinho } \\
\text { Costeiro }\end{array}$ \\
\hline 89 & $\begin{array}{l}\text { Parna da Serra da } \\
\text { Bodoquena }\end{array}$ & $\begin{array}{l}\text { Dec } s / n^{\circ} \text { de } 21 \text { de } \\
\text { setembro de } 2000\end{array}$ & $76.481,00$ & $\begin{array}{l}\text { Mato Grosso } \\
\text { do Sul }\end{array}$ & Cerrado \\
\hline 90 & Resex Corumbau & $\begin{array}{l}\text { Dec } \mathrm{s} / \mathrm{n}^{\mathrm{o}} \text { de } 21 \mathrm{de} \\
\text { setembro de } 2000\end{array}$ & $89.500,00$ & Bahia & $\begin{array}{l}\text { Marinho } \\
\text { Costeiro }\end{array}$ \\
\hline 91 & $\begin{array}{l}\text { Resex Marinha Delta do } \\
\text { Parnaíba }\end{array}$ & $\begin{array}{l}\text { Dec } s / n^{\circ} \text { de } 16 \text { de } \\
\text { novembro de } 2000\end{array}$ & $27.021,90$ & $\begin{array}{l}\text { Piauí e } \\
\text { Maranhão }\end{array}$ & $\begin{array}{l}\text { Marinho } \\
\text { Costeiro }\end{array}$ \\
\hline 92 & Resex Alto Tarauacá & $\begin{array}{l}\text { Dec } s / n^{\circ} \text { de } 08 \text { de } \\
\text { dezembro de } 2000\end{array}$ & $151.199,64$ & Acre & Amazônia \\
\hline
\end{tabular}

Tabela 15 Unidades de Conservação criadas no período militar na Amazônia Legal.

\begin{tabular}{|c|c|c|c|c|}
\hline N. ${ }^{\circ}$ & NOME & CRIAÇÃO & ÁREA/Ha & ESTADO(S) \\
\hline 01 & Parna da Amazônia & $\begin{array}{l}\text { Dec } \mathrm{n}^{\circ} 73.683 \text { de } 19 \text { de } \\
\text { fevereiro de } 1974\end{array}$ & $1.000 .000,00$ & Pará e Amazonas \\
\hline 02 & $\begin{array}{l}\text { Floresta Nacional do } \\
\text { Tapajós }\end{array}$ & $\begin{array}{l}\text { Dec } n^{\circ} 73.684 \text { de } 19 \text { de } \\
\text { fevereiro de } 1974 \text {. }\end{array}$ & $600.000,00$ & Pará \\
\hline 03 & Parna do Pico da Neblina & $\begin{array}{l}\text { Dec }{ }^{\circ} 83.550 \text { de } 05 \text { de junho } \\
\text { de } 1979\end{array}$ & $2.200 .000,00$ & Amazonas \\
\hline 04 & Rebio do Jaru & $\begin{array}{l}\text { Dec } n^{\circ} 83.716 \text { de } 11 \text { de julho } \\
\text { de } 1979\end{array}$ & $268.150,00$ & Rondônia \\
\hline
\end{tabular}




\begin{tabular}{|c|c|c|c|c|}
\hline 05 & Rebio do Rio Trombetas & $\begin{array}{l}\text { Dec } \mathrm{n}^{\text {o }} 84.018 \text { de } 21 \text { de } \\
\text { setembro de } 1979 .\end{array}$ & $385.000,00$ & Pará \\
\hline 06 & Parna de Pacaás Novos & 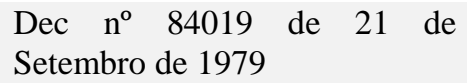 & $764.801,00$ & Rondônia \\
\hline 07 & Parna do Cabo Orange & $\begin{array}{l}\text { Dec } n^{\circ} 84.913 \text { de } 15 \text { de julho } \\
\text { de } 1980\end{array}$ & $619.000,00$ & Amapá \\
\hline 08 & Rebio Lago Piratuba & $\begin{array}{l}\text { Dec } n^{\circ} 84.914 \text { de } 16 \text { de julho } \\
\text { de } 1980\end{array}$ & $395.000,00$ & Amapá \\
\hline 09 & Parna do Jaú & $\begin{array}{lrlll}\text { Dec } \mathrm{n}^{\circ} & 85.200 & \text { de } & 24 & \text { de } \\
\text { setembro de } 1980 & & & \end{array}$ & $2.272 .000,00$ & Amazonas \\
\hline 10 & Esec de Maracá & $\begin{array}{l}\text { Dec } s / n^{\circ} \text { de } 02 \text { de junho de } \\
1981\end{array}$ & $101.312,00$ & Roraima \\
\hline 11 & Esec de Maracá-Jipioca & $\begin{array}{l}\text { Dec } s / n^{\circ} \text { de } 02 \text { de junho de } \\
1981\end{array}$ & $72.000,00$ & Amapá \\
\hline 12 & Esec do Rio Acre & $\begin{array}{l}\text { Decreto } \mathrm{n}^{\circ} 86.061 \text {, de } 2 \text { de } \\
\text { junho de } 1981\end{array}$ & $77.500,00$ & Acre \\
\hline 13 & Esec de Anavilhanas & $\begin{array}{l}\text { Dec } n^{\circ} 86.061 \text { de } 02 \text { de junho } \\
\text { de } 1981\end{array}$ & $350.018,00$ & Amazonas \\
\hline 14 & Esec do Jari & $\begin{array}{l}\text { Dec no } 87.092 \text { de } 12 \text { de abril de } \\
1982 \text { / Dec no } 89.440 \text { de } 13 \text { de } \\
\text { março de } 1984\end{array}$ & $227.126,00$ & Pará/Amapá \\
\hline 15 & Esec de Caracaraí & $\begin{array}{l}\operatorname{Dec}^{\circ} 87.222 \text { de } 31 \text { de maio de } \\
1982\end{array}$ & $80.560,00$ & Roraima \\
\hline 16 & Rebio do Abufari & $\begin{array}{lrlll}\text { Dec } \mathrm{n}^{\circ} & 87.585 & \text { de } & 20 & \text { de } \\
\text { setembro de } 1982 & & & \end{array}$ & $288.000,00$ & Amazonas \\
\hline 17 & Rebio do Guaporé & $\begin{array}{lllll}\text { Dec } n^{\circ} 87.587 & \text { de } & 20 & \text { de } \\
\text { setembro de } 1982\end{array}$ & $600.000,00$ & Rondônia \\
\hline 18 & Esec de Jutaí-Solimões & $\begin{array}{l}\text { Dec no } 88541 \text { de } 21 \text { de julho de } \\
1983\end{array}$ & $288.187,37$ & Amazonas \\
\hline 19 & $\begin{array}{l}\text { Arie Projeto Dinâmica } \\
\text { Biológica de Fragmentos } \\
\text { Florestais }\end{array}$ & $\begin{array}{l}\text { Resolução Conama } n^{\circ} 005 \text { de } \\
05 \text { de junho de 1984/Dec } n^{\circ} \\
91.884 \text { de } 05 \text { de nov de } 1985\end{array}$ & $3.288,00$ & Amazonas \\
\hline
\end{tabular}

Fonte: BRASIL. Instituto Chico Mendes de Conservação da Biodiversidade. Unidades de Conservação. Disponível em: <http://www.icmbio.gov.br/portal/biodiversidade/unidades-de-conservacao/biomasbrasileiros.html>. Acesso em: 15, 16, 17 e 18 jan. 2013; BRASIL. Portal da Legislação Governo Federal. Disponível em: 〈http://www4.planalto.gov.br/legislacao>. Acesso em: 15, 16, 17 e 18 jan. 2013.

Quadro 3 Ficha de Análise para o Estabelecimento do Parque Nacional da Serra do Divisor no Acre, proposta pela II Etapa do Plano do Sistema de Unidades de Conservação do Brasil de 1982.

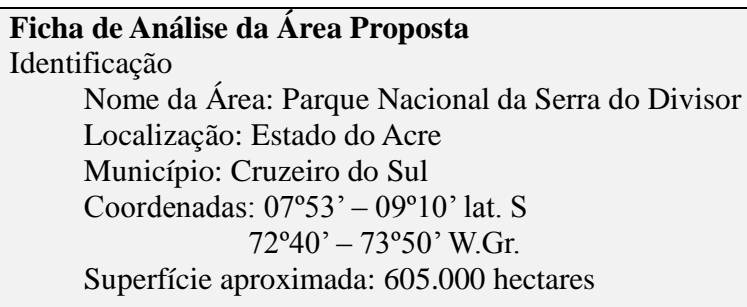

Descrição Resumida do Recurso

Enquadramento na Região

A área enquadra-se na província Biogeográfica Amazônica, segundo Udvardy (1975); na Divisão Fitogeográfica do Brasil, Rizzini (1963), encontra-se na Província Amazônica, Subprovíncia da Planície Terciária, Setor Sudoeste ou Acre. De acordo com trabalho de Ab’Sáber (1977) - Domínios Morfoclimáticos e Fitogeográficos, a área está incluída no Domínio Equatorial Amazônico.

Recursos Biofísicos

Fisiografia e Geomorfologia

A área proposta para o Parque Nacional da Serra do Divisor é banhada pela bacia do rio Juruá, constituindo importante divisor d'água para os rios que formam as bacias do Ucayali e Javari. O direcionamento geral dessa 
drenagem é de SO para NE, embora ocorra variação. Os cursos desses rios mostram-se meândricos e/ou sinuosos, com trechos retilinizados, segundo o volume 13 do Projeto RADAMBRASIL - Levantamento dos Recursos Naturais - 1977 (capítulo Geomorfologia).

Segundo esse documento, o relevo foi esculpido predominantemente em litologias sedimentares pliopleistocênicos de Formações Solimões. Dos processos erosivos, que trabalharam essas rochas resultaram: um planalto e uma vasta área deprimida, que domina toda a região. A área deprimida corresponde à Depressão rio Acre - rio Javari, onde encontram-se as colinas e cristas de pequena extensão. Apresenta evidências de uma atuação tectônica do tipo épico-genético. Quatro grupos individualizados de relevos definem a serra do Divisor. Apresenta forma alongada segundo direção NS. A formação das serras é dada por uma feição cuestiforme cujo "front" encontra-se dissecação em cristas alinhadas sem direção preferencial.

A Depressão rio Acre - rio Javari apresenta-se com uma predominância de ocorrência de formações colinosas, com dimensões em torno de $300 \mathrm{~m}$, e vales apresentando um aprofundamento de drenagem muito fraco. Nas Margens do rio Juruá, ocorrem grandes extensões de interflúvios tabulares, fugindo dos aspectos característicos da unidade.

Poderíamos resumir a evolução geomorfológica da seguinte maneira: no pleistoceno, com um ambiente morfoclimático característico de clima com estação seca prolongada definiu-se um limite provável de aplainamento; e neste mesmo período com um clima seco, os ventos geomorfológicos tiveram a seguinte sequência: dissecação do aplainamento, esvaziamento da serra do Divisor e a abertura de depressão rio Acre - rio Javari. Já, no Holoceno, com um ambiente de clima úmido, desenvolveu-se o terraço e posteriormente a planície.

Geologia

A área, na sua grande maioria está encravada em terreno do Terciário-Quaternário de Formações Solimões, constituído de argilitos vermelhos, mosqueados, cinza esverdeados, maciços ou acamados, com concreções carboníticas e gisíferas, ocasionalmente, material incarbonizado - turfa e linito - com concentrações de fósseis vegetais e animais, podendo apresentar estratificações cruzadas. Faz contato discordante com as formações cretáceas da serra do Divisor.

Essas formações cretáceas, (Cretáceo Superior), Formação Ramon, Formação Divisor, Formação Rio Azul e Formação Moa, são as litologias que ocorrem na Serra do Divisor, e são constituídas de:

Formação Ramon: argilitos, siltitos, e folhelhos intercalados com níveis de camadas calcáreas, contendo fósseis de gastrópodos.

Formação Divisor: arenitos maciços com estratificação cruzadas, de cores branca, amarela e vermelha, granulometria média, com bom selecionamento. Visíveis níveis mais grosseiros ao longo da seção.

Formação Rio Azul: arenitos frios, em bancos, com intercalações de siltitos, cinza esverdeada.

Formação Moa: arenitos comuns, frios e médios com níveis conglométricos estratificações cruzadas. Apresenta finas camadas de argilas e siltitos.

A Serra do Divisor ressalta-se em função da movimentação de sua estrutura, com faixas dobradas (Anticlinal do Divisor) e estruturas folhadas inversas de direções preferenciais N-S e NO-SE.

Pedologia

A área proposta é constituída pelos Podzólicos Vermelho Amarelo, RADAMBRASIL (1977).

Os solos dessa unidade são caracterizados por apresentarem um horizonte B textural, o qual se caracteriza por possuir aumento significante no conteúdo de argila, em relação ao horizonte aluvial e, também, por apresentar cerosidade revestindo os elementos estruturais. São solos bem desenvolvidos, não hidromórficos, de textura argilosa, profundos e medianamente profundos, bem, a moderadamente drenados e apresentam na grande maioria, soma de bases, capacidade de troca de cátions e saturação de bases bastante elevada, e argila de atividade alta.

Associação: associam-se ao Brunizém Avermelhado de textura argilosa e ao latossolo Vermelho Amarelo, álico e de textura argilosa.

Nas margens dos rios Juruá, Juruá-Mirim e Ouro Preto ocorrem os solos Gleyzados pouco Húmico, eutróficos e distróficos de textura argilosa e argila de atividade alta e baixa, porém insignificante em suas dimensões na área proposta.

\section{Aptidão Agrícola}

A maioria da área proposta apresenta aptidão, para cultura anual regular no sistema de manejo primitivo e restrita no sistema de manejo desenvolvido, e para cultura perene apresenta-se restrita, nos dois níveis de manejo. Apresenta aptidão regular para pastagem e silvicultura. O fator limitante mais importante é o relevo, o qual varia desde suavemente ondulado a montanhoso.

Clima

A área está sob influência de dois tipos climáticos, segundo a classificação de Gausse, em Xeroquimênio, que domina a região sul, apresentando temperatura média superior a $15^{\circ} \mathrm{C}$ e um período seco 1 a 3 meses. No resto da área, o clima Termaxérico com temperatura superior a $20^{\circ} \mathrm{C}$, sem apresentar período seco. $\mathrm{O}$ total anual de precipitação é da ordem de $2.300 \mathrm{~mm}$ e nos três meses menos chuvosos, o total do trimestre varia de $250 \mathrm{~mm}$ a 200 $\mathrm{mm}$. Durante todo ano existe Massa de Ar Equatorial, sendo no verão pela Massa Polar. Resulta um clima tropical chuvoso com períodos curtos de temperatura amena.

Vegetação

A maioria da área é coberta de Floresta Tropical Aberta, característica da sub-região dos baixos platôs da Amazônia. Ocorrendo numa topografia de relevo dissecado, essa floresta apresenta-se com duas fisionomias: Aberta de Cipó e Aberta de Palmeira. A Floresta Aberta de Cipó com fisionomia caracterizada pelo relativo espaçamento entre as árvores, que, na sua maioria, têm as copas e galhos envolvidos por elementos sarmentosos pendentes, dando a essa floresta um aspecto peculiar de formas colunares sempre verdes, dispostos assimetricamente. Dentre as inúmeras espécies arbóreas, destacam-se: juá, castanha-de-periquito, taperebá, inharé, cachuá, janitá, fava-de 
espinho, mututi-mole e murupita e entre os cipós destacam-se: escada-de-jabuti, timboaçu, macuna, cipó-cruz e aburta.

A Floresta Aberta de Palmeira apresenta a densidade dos grupamentos das diversas espécies de palmae variável, aumentando nos vales e áreas aplainadas e diminuindo à medida que se instalam nas encostas. Essa distribuição especial influi decisivamente na estrutura da floresta, com grande espaçamento entre as espécies arbóreas e pequena biomassa, até relativamente mais densa. Dentre as inúmeras espécies de palmeiras predominam: paxiúba-lisa, patauá, açaí, jaci, murumuru, paxiúba-barriguda, inajá e jarima. Margeando os rios Juruá, Juruá-Mirim e Ouro Preto, além da paxiúba e açaí, também ocorrem: jauari, ceirana,canarana e Iponea sp., característica da Floresta Aberta Aluvial das planícies inundáveis.

Ocorrem, também, na superfície dissecada da serra do Divisor, a Floresta Densa e Aberta Submontana, com a seguinte distribuição espacial: na porção mais alta da serra ocorre a Floresta Densa com poucas árvores emergentes e na metade inferior das encostas (colúvios) e nos vales (alúvios) predomina a Floresta Aberta de Palmeiras. Destaca-se, dentre as inúmeras espécies: abioranas, cariperana, ingá-xixica, louro preto, mapatirana, matamatás, seringueira, ucuuba-chorona e urucurana. Dentre as palmeiras destacam-se: bacaba, jauari, patauá e paxiúba-lisa e barriguda.

Fauna

A existência de fauna de diversos ecossistemas é uma realidade. No âmbito geral da área proposta não tem sido efetuado estudos no tocante à sua composição faunística. O próprio desconhecimento das espécies e subespécies, que habitam aquele local, é sem dúvida, uma forte imposição para cabal proteção daquele ecossistema. Essa preservação permitirá manter a área intocada até que estudos aprofundados possam ser levados a efeito.

Valores Culturais

Nessa fase dos estudos efetuados na área proposta, não há evidência levantadas sobre os valores culturais da região.

Uso Potencial da Área

A maior parte da área possui regulares condições de explotabilidade madeireira, seringa e sorva.

Fatores Institucionais

Uso Existente da Terra

O estado do Acre, situado na parte mais ocidental do País, com baixo índice de ocupação da terra e baixa densidade populacional, reflete a precaridade do uso da terra pela propriedade rural e consequentemente o uso existente da terra, na área proposta, está restrito a seringa e a sorva.

Posse da Terra

A área proposta localiza-se nos limites fronteiriços Peru/Brasil, na faixa de fronteira, considerada área indispensável à Segurança Nacional. Há conhecimento de ocupações humanas às margens dos rios principais da área proposta, com atividades principais no extrativismo da seringa e sorva.

Conflitos do Uso da Terra

Praticamente inexiste conflitos do uso da terra na área proposta devido à baixa ocupação humana.

Infra-estrutura Atual e Prevista

Atualmente a infraestrutura de transportes é precária. O principal acesso à área é feito através dos rios Javari e Juruá. O transporte aéreo, que é feito em linha comercial, ocorre uma vez por semana com linhas para Tefé-Manaus e para Rio Branco. Já foi iniciada a implementação da rodovia perimental Norte, BR-307, cujo traçado cortará a região com destino ao Peru.

Atividades Projetadas para a Área

Pelos contactos mantidos com a Secretaria de Planejamento do Estado do Acre e Instituto Nacional de Colonização e Reforma Agráfia-MA, não está prevista nenhuma atividade para a área.

\section{Critérios de Avaliação}

1. Representatividade de Região Ecológica Natural.

2. Representatividade de Região Fisiográfica Geomorfológica.

3. Habitat de espécie rara ou ameaçada de extinção.

4. Diversidade ecológica.

5. Raridade (aspectos mais notáveis).

6. Qualidade estética.

7. Estado natural (ausência de alterações antropogênicas)

8. Valor Histórico, Cultural e Antropológico.

9. Potencial educativo.

10. Potencial científico e monitoramente.

11. Potencial recreativo.

12. Efetividade como Unidade de Conservação (área suficiente ausência de usos conflitantes)

13. Valor para turismo internacional

\begin{tabular}{|c|c|c|c|c|}
\hline $\mathbf{A}$ & B & C & D & $\mathbf{E}$ \\
\hline & $X$ & & & \\
\hline \multirow[t]{2}{*}{$\mathrm{X}$} & & & & \\
\hline & $X$ & & & \\
\hline \multicolumn{5}{|l|}{$X$} \\
\hline \multicolumn{5}{|l|}{$\mathrm{X}$} \\
\hline \multicolumn{5}{|l|}{$\mathrm{X}$} \\
\hline \multicolumn{5}{|l|}{$\mathrm{X}$} \\
\hline & & & & $X$ \\
\hline & & & & $X$ \\
\hline \multicolumn{5}{|l|}{$\mathrm{X}$} \\
\hline & $\mathrm{X}$ & & & \\
\hline & $\mathrm{X}$ & & & \\
\hline $\mathrm{X}$ & & & & \\
\hline
\end{tabular}

A-Excelente - B-Bom - C-Regular

D- Inadequado - E-Não Considerado 
Declaração de Significância

A importância de se proteger a área de interesse ficou patenteada na reunião do II CIT - Comitê Intergovernamental Técnico para Proteção da Flora e Fauna Amazônicas, com acordo firmado entre os países Brasil e Peru para criação de unidades de conservação limítrofes. Outros fatores de relevância foram considerados; com a presença de fósseis de restos animais e vegetais, as evidências endêmicas que a área apresenta, com faixa de segurança de fronteira e outros.

MINUTA DO DECRETO

Decreto $\mathrm{N}^{\circ}$ de de de
Cria, no Estado do Acre, o PARQUE NACIONAL DA SERRA DO DIVISOR

O PRESIDENTE DA REPÚBLICA, usando da atribuição que lhe confere o artigo 81, item III, da Constituição, e nos termos do artigo 5º alínea "a", da Lei n 4.771, de 15 de setembro de 1965.

DECRETA:

Art. $1^{\circ}$ - É criado, no Estado do Acre, com uma área estimada em 605.000 ha (seiscentos e cinco mil hectares), subordinado ao Instituto Brasileiro de Desenvolvimento Florestal (IBDF), o PARQUE NACIONAL DA SERRA DO DIVISOR.

Parágrafo Único - A área de que trata este artigo, está localizada entre as coordenadas $07^{\circ} 50^{\prime} \mathrm{S}$ e $09^{\circ} 10^{\prime} \mathrm{S}, 72^{\circ} 45^{\prime}$ W. Gr. E $73^{\circ} 41^{\prime}$ W. Gr. O limite norte do Parque Nacional será a estrada que irá ligar o Peru a Cruzeiro do Sul, no Acre, a qual deverá iniciar no ponto de coordenadas $07^{\circ} 8^{\prime} \mathrm{S} 73^{\circ} 38^{\prime}$ W. Gr., indo pela estrada até o ponto de coordenada $73^{\circ} 22^{\prime}$ W. Gr. e $07^{\circ} 52^{\prime}$ S e deste ponte segue o divisor de águas das bacias dos rios do Moura ou Paraná da Viúva e do rio Azul, continuando a seguir pelo divisor do rio Moura ou Paraná da Viúva com o rio Tamboriaco até encontrar a nascente do igarapé Ubio; deste ponto desce o igarapé Ubio até a sua foz no rio Juruá Mirim; deste ponto desce o rio Juruá Mirim até encontrar com o rio Juruá; deste ponto sobe o rio Juruá até encontrar o limite norte da Reserva Indígena situada no alto do rio Juruá; deste ponto segue o limite norte da Reserva Indígena até encontrar a fronteira do Brasil com o Peru; no Estado do Acre; até encontrar o ponto inicial desta descrição, fechando o perímetro.

Art. $2^{\circ}$ - O Parque Nacional da Serra do Divisor tem finalidade precípua proteger a flora, a fauna e as belezas naturais nesse existentes, ficando sujeito ao regime especial do Código Florestal, instituído pela Lei no 4.771 , de 15 de setembro de 1965 .

Art. $3^{\circ}$ - É fixado o prazo de 180 (cento e oitenta) dias, a partir da publicação deste Decreto, para a elaboração do respectivo Plano de Manejo, na forma do disposto no Regulamento dos Parques Nacionais Brasileiros, aprovado pelo Decreto $\mathrm{n}^{\circ} 84.017$, de 21 de setembro de 1979.

Art. $4^{\circ}$ - Este Decreto entra em vigor na data de sua publicação, revogadas as disposições em contrário.

Fonte: PÁDUA, et. al., 1982, p. 126-130.

Quadro 4 Decreto de criação do Parque Nacional da Serra do Divisor - AC: 1989.

\section{DECRETO No 97.839, DE 16 DE JUNHO DE 1989.}

Cria o Parque Nacional da Serra do Divisor.

O PRESIDENTE DA REPÚBLICA, usando da atribuição que lhe confere o art. 84, inciso IV, e tendo em vista o disposto no art. 225, inciso III, ambos da Constituição, e de acordo com o art. 5. ${ }^{\circ}$ da Lei $n^{\circ} 4.771$, de 15 de setembro de 1965, bem assim com o Decreto n. ${ }^{\circ} 84.017$, de 21 de setembro de 1979, DECRETA:

Art. $1 .^{\circ}$ Fica criado, no Estado do Acre, o Parque Nacional da Serra do Divisor, abrangendo terras dos Municípios de Mâncio Lima e Cruzeiro do Sul, com o objetivo de proteger e preservar amostra dos ecossistemas ali existentes, assegurando a preservação de seus recursos naturais, proporcionando oportunidades controladas para uso pelo público, educação e pesquisa científica.

Art. 2. ${ }^{\circ}$ O Parque Nacional da Serra do Divisor está localizado no extremo oeste do Estado do Acre, na fronteira

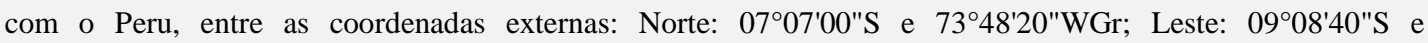
$72^{\circ} 40^{\prime} 00^{\prime \prime W G r}$; Sul: $09^{\circ} 24^{\prime} 40^{\prime \prime S}$ e $73^{\circ} 12^{\prime} 40^{\prime \prime} W G r$; Oeste: $07^{\circ} 32^{\prime} 40^{\prime \prime S}$ e $73^{\circ} 59^{\prime} 20^{\prime \prime W G r}$, tendo 09 seguintes limites, descritos a partir das cartas na escala de 1:250.000, nº SB.18-2-D/C, SC-18-X-D e SC-18-X-B/A, editadas pelo Departamento Nacional de Produção Mineral em 1977:

Norte: partindo do ponto 1 de coordenadas geográficas aproximadas (c.g.a.) $7^{\circ} 14^{\prime} 32^{\prime \prime} \mathrm{S}$ e $73^{\circ} 42^{\prime} 54^{\prime \prime} \mathrm{WGr}$, situado no marco geodésico demarcador do limite internacional entre Brasil e Peru, segue-se por uma linha seca de azimute aproximado de $123^{\circ} 00^{\prime}$ por aproximadamente 8.500 metros, até o ponto de c.g.a. $7^{\circ} 16^{\prime} 58^{\prime \prime} \mathrm{S}$ e $73^{\circ} 38^{\prime} 58^{\prime \prime W G r}$, situado na cabeceira do Igarapé Timbaúba (ponto 2); daí, segue por uma linha seca de azimute aproximado $154^{\circ} 30^{\prime}$ Sul, com cerca de 1.400 metros, até atingir a cabeceira do Igarapé República, no ponto de 
c.g.a. $7^{\circ} 18^{\prime} 40^{\prime \prime S}$ e $73^{\circ} 38^{\prime} 58^{\prime \prime W G r}$, ponto 3; daí, segue-se a jusante, pela margem esquerda do Igarapé República até sua foz no Rio Moa (ponto 4), seguindo pela margem esquerda do Rio Moa até a foz do Rio Azul, ponto de c.g.a. $7^{\circ} 25^{\prime} 15^{\prime \prime} \mathrm{S}$ e $73^{\circ} 17^{\prime} 02^{\prime \prime} \mathrm{WGr}$ (ponto 5)

Leste: do ponto 5 segue-se a montante, pela margem direita do Rio Azul, até o ponto de c.g.a. $7^{\circ} 51^{\prime} 11$ "S e 73²4'30"WGr, situado na confluência do Rio Azul com um seu afluente pela margem direita (ponto 6); daí, segue pela margem direita deste afluente até a cabeceira de um dos seus formadores, no ponto de c.g.a. 0803'40"S e 73³0'00"WGr, (ponto 7); daí, segue por uma linha seca de azimute aproximado $141^{\circ} 30^{\prime}$ e distância aproximada 4.000 metros, até atingir o ponto de c.g.a. $08^{\circ} 04^{\prime} 40 " \mathrm{~S}$ e $73^{\circ} 29^{\prime} 00^{\prime \prime} \mathrm{WGr}$; situado na cabeceira do Rio Tamboriaco (ponto 8); segue a jusante, pela margem esquerda do Rio Tamboriaco, até sua confluência com o Rio Juruá-Mirim (ponto 9); daí, segue-se pelo Rio Juruá-Mirim, no sentido jusante, até o foz de um seu afluente; pela margem direita, no ponto de c.g.a. $08^{\circ} 11^{\prime} 00^{\prime \prime S}$ e $72^{\circ} 53^{\prime} 25^{\prime \prime} \mathrm{WGr}$ (ponto 10); daí, segue-se por uma linha seca de azimute aproximado $163^{\circ} 00^{\prime \prime}$ e distância aproximada 23.400 metros, até atingir a confluência do Rio Ouro Preto com o Rio Juruá, ponto de c.g.a. 08²3'13" S e 72³9'41"WGr; (ponto 11) daí, segue-se a montante, pela margem esquerda do Rio Juruá, até atingir a foz do Igarapé São Luiz, seu afluente pela margem esquerda (ponto 12).

Sul: do ponto 12, segue-se a montante, pela margem direita do Igarapé São Luiz, até o ponto de c.g.a. $08^{\circ} 56^{\prime} 24^{\prime \prime S}$ e 7252'20"WGr; (ponto 13); daí, segue-se por uma linha seca de azimute aproximado $168^{\circ} 00^{\prime}$ e distância aproximada 7.800 metros, até atingir o ponto de c.g.a. 0900'33"S e 7251'10"WGr, situado na confluência do Rio Amônia com um seu afluente pela margem esquerda (ponto 14); daí, segue-se por uma linha seca de azimute aproximado $236^{\circ} 00^{\prime \prime}$ e distância aproximada de 11.200 metros, até atingir um marco de fronteira Brasil/Peru, no ponto de c.g.a. $09^{\circ} 03^{\prime} 52^{\prime \prime S}$ e $72^{\circ} 56^{\prime} 20^{\prime \prime W G r}$ (ponto 15 ). Oeste: do ponto 15 segue-se acompanhando a divisa internacional Brasil/Peru, no sentido norte até atingir o ponto 1, inicial da presente descrição.

Art. $3^{\circ}$ Fica autorizada a implantação futura do trecho da BR-364 que corta os limites deste Parque Nacional, devendo ser observadas, para este fim, todas as medidas de proteção ambiental e compatibilização do traçado com as características naturais da área.

Art. $4^{\circ}$ Fica estabelecido o prazo de 5 (cinco) anos para a elaboração do Plano de Manejo do Parque Nacional da Serra do Divisor.

Art. $5^{\circ}$ As terras e benfeitorias localizadas dentro dos limites descritos no artigo $2^{\circ}$ deste Decreto ficam declaradas de utilidade pública, para fins de desapropriação.

Art. $6^{\circ} \mathrm{O}$ Parque Nacional da Serra do Divisor fica subordinado ao Instituto Brasileiro do Meio Ambiente e dos Recursos Naturais Renováveis, que deverá tomar as medidas necessárias para sua efetiva implantação.

Art. $7^{\circ}$ Este Decreto entra em vigor na data de sua publicação, revogadas as disposições em contrário.

Brasília, 16 de junho de 1989; $168^{\circ}$ da Independência e $101^{\circ}$ da República.

JOSÉ SARNEY

João Alves Filho

Fonte: BRASIL. Decreto n. 97.839, de 16 de junho de 1989. Cria o Parque Nacional da Serra do Divisor. Brasília: 1989.

Quadro 5 Características das diversas fases de um Plano de Manejo de Unidades de Conservação de Uso Indireto - IBAM, 1996.

PLANO DE MANEJO - FASE 1: O pressuposto é que não existe nenhum instrumento de planejamento anterior e a base de conhecimento sobre a Unidade de Conservação é limitada. Os Programas de Manejo nesta fase visariam unicamente à: 1) Manutenção e ordenação dos usos presentes (caso sejam adequados) na Unidade de Conservação até o momento; 2) Minimização dos impactos das atividades até então desenvolvidas; 3 ) Fortalecimento da proteção da Unidade; 4) integração da Unidade com as comunidades vizinhas, e 5) Ampliação do conhecimento sobre a Unidade. As ações de manejo previstas nessa fase são baseadas em informação já disponíveis, em visitas à UC e à sua Zona de Transição. Os estudos necessários para as ações de manejo serão desenvolvidos imediatamente. O prazo de elaboração é de 5 meses e implementação de 3 anos. No segundo ano, já se inicia o planejamento para a FASE 2. 
PLANO DE MANEJO - FASE 2: O pressuposto é que já exista um instrumento prévio de planejamento e uma base de dados básica sobre a UC. Os Programas de Manejo nesta fase visariam à: 1) Implementação de ações de manejo dos recursos; 2) Aumento do conhecimento; 3) Aumento da proteção; 4) Incentivo a adoção de alternativas de desenvolvimento das áreas vizinhas; e 50 Definição de áreas destinadas à visitação pública, recreação e educação ambiental. O horizonte de implementação é de 5 anos. No segundo ano de sua implementação, começam os estudos que apoiarão a elaboração do Plano de Manejo da FASE 3. Os levantamentos de campo usarão a metodologia de Avaliação Ecológica Rápida (AER) sobre basicamente os mesmos aspectos tratados na FASE 1.

PLANO DE MANEJO - FASE 3: O pressuposto é que já exista um instrumento de planejamento e a base de dados é suficiente para o manejo completo da Unidade. O Plano de Manejo, nesta fase, é baseado em pesquisas mais detalhadas identificadas na fase anterior dependendo das especificidades de cada UC e permitirá dar início a ações específicas de manejo dos recursos naturais e culturais da UC. O aprofundamento nos conhecimentos da Unidade existente irá garantir maior eficiência nas ações de manejo e a revisão do zoneamento estabelecido na fase anterior. É previsto para sua implementação um horizonte temporal de 5 anos. Será sujeito periodicamente a um processo permanente de avaliação revisão de acordo com os novos conhecimentos adquiridos.

Fonte: IBAMA, 1996.

\title{
Quadro 6 Estrutura dos Planos de Manejo - IBAMA, 1996.
}

\author{
Encarte 1 \\ Informações gerais da Unidade de Conservação. A informação geral da unidade é resumida na Ficha Técnica da \\ Unidade de Conservação. Além disso, outros campos devem ser desenvolvidos, como; o acesso a unidade, o \\ histórico e os antecedentes legais, a origem do nome e a situação fundiária.
}

\section{Encarte 2}

Contexto Federal. Localiza a unidade no contexto federal, possibilitando reconhecer o seu enquadramento sobre aspectos distintos.

\section{Encarte 3}

Contexto Estadual. Localiza a unidade no contexto estadual, sendo focado: a divisão política e administrativa, o uso e ocupação do solo, as unidades de conservação estaduais e os órgãos estaduais.

\section{Encarte 4}

Contexto Regional. Localiza a unidade na sua área de influência, ou seja, os municípios da microrregião e as microbacias onde ela está inserida. Deste modo, deve-se abordar: a área de influência, o uso e ocupação do solo e principais atividades econômicas, a caracterização da população, as características culturais, a infraestrutura disponível, as ações ambientais realizadas por outras instituições e o apoio institucional.

\section{Encarte 5}

Unidade de Conservação e Zona de Transição. Deve-se realizar um diagnóstico da unidade e de sua Zona de Transição, caracterizando seus fatores abióticos, bióticos e antrópicos, a infraestrutura e os problemas existentes.

\section{Encarte 6}

Planejamento da Unidade de Conservação. São propostos: os objetivos específicos de manejo da unidade, as diretrizes de planejamento, o zoneamento, os programas de manejo, as áreas de desenvolvimento, a capacidade suporte, a circulação interna, o cronograma físico-financeiro, a bibliografia utilizada e os anexos.

\section{Encarte 7}

Projetos Específicos. Deve ser elaborado após o Plano de manejo. Assim, são propostas atividades pontuais que necessitam a participação de profissionais mais especializados.

\section{Encarte 8}

Monitoria e Avaliação. Possibilita a interação entre o planejamento e a execução, permitindo a correção de distorções e retroalimentação constante do processo de planejamento.

Fonte: IBAMA, 1996. 